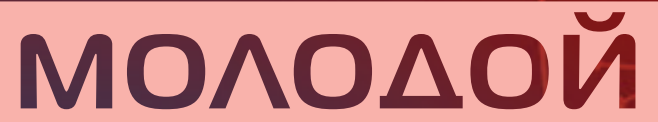

ISSN 2072-0297
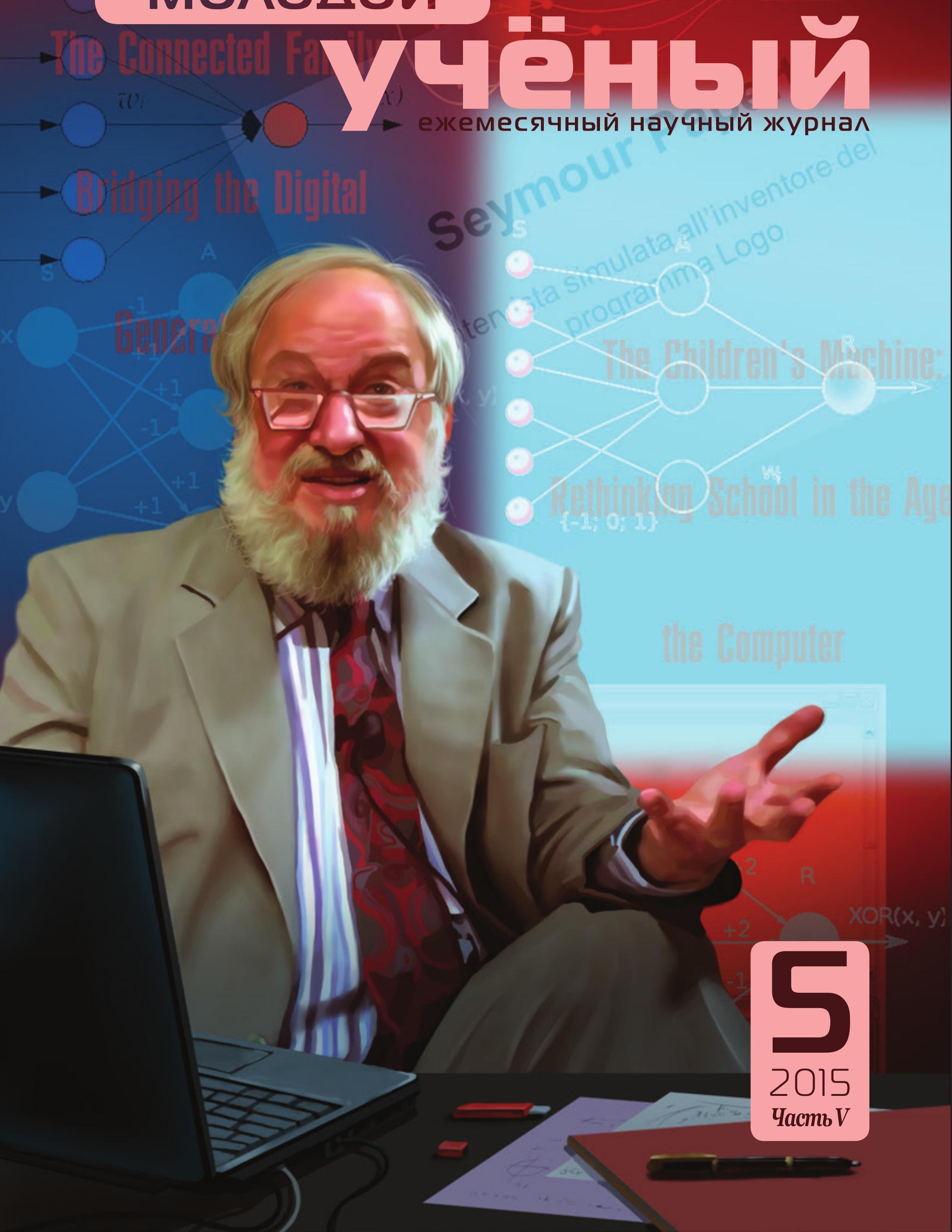


\title{
Молохой учёный
}

\author{
Ежемесячный научный журнал
}

№ 5 (85) / 2015

\section{РЕДАКЦИОННАЯ КОЛЛЕГИЯ:}

Главный редактор: Ахметова Галия Дуфаровна, доктор филологических наук

Члены редакционной коллегии:

Ахметова Мария Николаевна, доктор педагогических наук

Иванова Юлия Валентиновна, доктор философских наук

Қаленский Александр Васильевич, доктор физико-математических наук

Лактионов Константин Станиславович, доктор биологических наук

Сараева Надежда Михайловна, доктор психологических наук

Авдеюк Оксана Алексеевна, кандидат технических наук

Алиева Тарана Ибрагим кызы, кандидат химических наук

Ахметова Валерия Валерьевна, кандидат медищинских наук

Брезгин Вячеслав Сергеевич, кандидат экономических наук

Данилов Олег Евгеньевич, кандидат педагогических наук

Дёмин Александр Викторович, кандидат биологических наук

Дядюн Кристина Владимировна, кандидат юридических наук

Желнова Кристина Владимировна, кандидат экономических наук

Жуйкова Тамара Павловна, кандидат педагогических наук

Игнатова Мария Александровна, кандидат искусствоведения

Коварда Владимир Васильевич, кандидат физико-математических наук

Комогорцев Максим Геннадьевич, кандидат технических наук

Котляров Алексей Васильевич, кандидат геолого-минералогических наук

Кузьмина Виолетта Михайловна, кандидат исторических наук, кандидат психологических наук

Кучерявенко Светлана Алексеевна, кандидат экономических наук

Лескова Екатерина Викторовна, кандидат физико-математических наук

Макеева Ирина Александровна, кандидат педагогических наук

Матроскина Татьяна Викторовна, кандидат экономических наук

Мусаева Ума Алиевна, кандидат технических наук

Насимов Мурат Орленбаевич, кандидат политических наук

Прончев Геннадий Борисович, кандидат физико-математических наук

Семахин Андрей Михайлович, кандидат технических наук

Сенюшкин Николай Сергеевич, кандидат технических наук

Ткаченко Ирина Георгиевна, кандидат филологических наук

Яхина Асия Сергеевна, кандидат технических наук

На обложке изображен Сеймур Пейперт (род. 1928) - выдающийся математик, программист, психолог и педагог. Один из основоположников теории искусственного интеллекта, создатель языка Logo.

Статьи, поступающие в редакцию, рецензируются. За достоверность сведений, изложенных в статьях, ответственность несут авторы. Мнение редакции может не совпадать с мнением авторов материалов. При перепечатке ссылка на журнал обязательна. Материалы публикуются в авторской редакции.

\section{АДРЕС РЕДАКЦИИ:}

420126, г. Қазань, ул. Амирхана, 10a, a/я 231. E-mail: info@moluch.ru; http://www.moluch.ru/.

Учредитель и издатель: ООО «Издательство Молодой ученый»

Тираж 1000 экз.

Отпечатано в типографии издательства «Молодой ученый», г. Қазань, ул. Академика Арбузова, д. 4 
Журнал зарегистрирован Федеральной службой по надзору в сфере связи, информационных технологий и массовых коммуникаций.

Свидетельство о регистрации средства массовой информации ПИ № ФС77-38059 от 11 ноября 2009 г. Журнал входит в систему РИНЦ (Российский индекс научного цитирования) на платформе elibrary.ru. Журнал включен в международный каталог периодических изданий «Ulrich's Periodicals Directory».

\section{Ответственные редакторы:}

Қайнова Галина Анатольевна

Осянина Екатерина Игоревна

\section{Международный редакционный совет:}

Айрян Заруи Геворковна, кандидат филологических наук, доцент (Армения)

Арошидзе Паата Леонидович, доктор экономических наук, ассоциированный профессор (Грузия)

Атаев Загир Вагитович, кандидат географических наук, профессор (Россия)

Борисов Вячеслав Викторович, доктор педагогических наук, профессор (Украина)

Велковска Гена Цветкова, доктор экономических наук, доцент (Болгария)

Гайич Тамара, доктор экономических наук (Сербия)

Данатаров Агахан, кандидат технических наук (Туркменистан)

Данилов Александр Максимович, доктор технических наук, профессор (Россия)

Досманбетова Зейнегуль Рамазановна, доктор философии (PhD) по филологическим наукам (Kaзахстан)

Ешиев Абдыракман Молдоалиевич, доктор медицинских наук, доцент, зав. отделением (Кыргызстан)

Игисинов Нурбек Сагинбекович, доктор медицинских наук, профессор (Казахстан)

Қадыров Кутлуг-Бек Бекмурадович, кандидат педагогических наук, заместитель директора (Узбекистан)

Кайгородов Иван Борисович, кандидат физико-математических наук (Бразилия)

Каленский Александр Васильевич, доктор физико-математических наук, профессор (Россия)

Козырева Ольга Анатольевна, кандидат педагогических наук, доцент (Россия)

Лю Цзюань, доктор филологических наук, профессор (Китай)

Малес Людмила Владимировна, доктор социологических наук, доцент (Украина)

Нагервадзе Марина Алиевна, доктор биологических наук, профессор (Грузия)

Нурмамедли Фазиль Алигусейн оглы, кандидат геолого-минералогических наук (Азербайджан)

Прокопьев Николай Яковлевич, доктор медицинских наук, профессор (Россия)

Прокофьева Марина Анатольевна, кандидат педагогических наук, доцзент (Казахстан)

Ребезов Максим Борисович, доктор сельскохозяйственных наук, профессор (Россия)

Сорока Юлия Георгиевна, доктор социологических наук, доцент (Украина)

Узаков Гулом Норбоевич, кандидат технических наук, доцент (Узбекистан)

Хоналиев Назарали Хоналиевич, доктор экономических наук, старший научный сотрудник (Таджикистан)

Хоссейни Амир, доктор филологических наук (Иран)

Шарипов Аскар Қалиевич, доктор экономических наук, доцент (Казахстан)

Художник: Шишков Евгений Анатольевич

Верстка: Голубцов Максим Владимирович 


\section{СОДЕРЖАНИЕ}

\section{ПЕДАГОГИКА}

\section{Абжамалова Н.Д., Жданова Э. А. \\ Современные педагогические методы как многоаспектные явления в обучении английскому языку...}

Абрамова В.Ю., Елизарова И.С.

Модель методики внеклассной работы по курсу «0сновы безопасности жизнедеятельности», способствующая повышению качества знаний учащихся 10-11 классов по экологической безопасности

\section{Адаев И.А.}

Педагогический потенциал информационных технологий в профессиональной подготовке будущих учителей химии

\section{Алешкина 0.В.}

Формирование жизненных стратегий у учащихся 430

\section{Алиева А.э.}

Интеграционные подходы в обучении чтению и письму на уроках английского языка.

\section{Баликаева М. Б., Лапицкая С. И.}

Формирование профессиональной мобильности будущих инженеров в вузе в процессе профессиональной подготовки

\section{Болтаев А. A.}

Социально-педагогические основы привития национально-духовных ценностей в сознание студентов

Веселова Л.А.

Дидактические игры на современном уроке химии

Власова Т.С., Сунгатуллин Р.И., Закирова Н.М. Особенности физического воспитания студентов, имеющих отклонения в здоровье. Проблемы мотивации физкультурной активности студентов в вузе .441

\section{Вовненко С.И.}

Способы повышения мотивации при изучении английского языка

Гайсумова Л.Д., Эльмурзаев Р.С., Иразова М.А. Формирование географических представлений на уроках географии в условиях современной школы 446

\section{Григоровских Е. С.}

Технология чтения-рассматривания на уроках во 2 классе.

Демидова 0.М.

Creating a textbook in ESP on the basis of a professional discipline

Длужневская Д. А.

Поликультурное пространство как основа построения содержания образования в начальной школе

Дружинин К. П., Куимова М.В.

About problem-based learning at lessons of mathematics

Егорова Ю.А.

Направления целеполагания студента вуза в сфере саморазвития

\section{Жерякова С. В.}

Сущность категории «здоровый образ жизни детей дошкольного возраста» и факторы формирования здорового образа жизни дошкольников в контексте педагогических исследований второй половины XX века.

Жуйкова Т. П., Томчак Е. В.

Использование блоков Дьенеша в восприятии формы предметов и геометрических фигур детьми младшего дошкольного возраста 464 


\section{Искакова М. А.}

Метод моделирования в реализации преемственности воспитания нравственных качеств личности в дошкольном и общеобразовательном учреждениях .468

\section{Каргина Е. М.}

Роль оценочных способностей в формировании и развитии личности обучающегося .470

Каргина Е. М.

Генезис методики преподавания иностранных языков как науки

\section{Карташова Ю.А.}

Сущность интернационального воспитания в контексте всестороннего развития пионеров (60-80-гг. XX в.)

\section{Комарова Е. В.}

Показатели понимания содержания текста на иностранном языке

\section{Комарова Е. В.}

Реферирование как один из самых распространенных приемов работы с иноязычным текстом в процессе обучения иностранному языку в вузе.

\section{Краснова Т.И.}

Повышение качества обучения в вузе в условиях интеграции смешанной модели обучения

\section{Краснова Т. И.}

Перспективы использования смешанного обучения при обучении иностранному языку

\section{Куркан Н.В.}

Эффективность смешанного обучения при обучении иностранному языку в условиях современного образования

Мамедова С. А.

Применение ИТ на уроках русского языка в целях развития самостоятельного и творческого мышления учащихся

\section{Маркова Н. А.}

Развитие самостоятельности в процессе обучения иностранному языку

в неязыковом вузе 493

Маскаева А. В., Барсукова И. Н.

Организация проектной деятельности как средство развития исследовательских умений учащихся 7 класса на уроках биологии

\section{Милотаева 0.С.}

Особенности работы над лексикой в процессе преподавания иностранного языка в вузе .....501

\section{Милотаева 0.С.}

Особенности обучения работе с иноязычным текстом в вузе .....................................503

Миналиева М.А., Рачителева Н.А., Кошенкова Н. В.,

За сознательность в обучении орфографии .505

Ноздрина 0.И.

Формирование произносительной культуры младших школьников 



\title{
ПЕДАГОГИКА
}

\section{Современные педагогические методы как многоаспектные явления в обучении английскому языку}

\author{
Абжамалова Нильжан Дауировна, преподаватель; \\ Жданова Элеонора Андреевна, преподаватель \\ Карагандинский государственный технический университет (Казахстан)
}

$M$ етоды обучения — один из важнейших компонентов учебного процесса. Без применения соответствующих методов невозможно реализовать спланированные учителем цели и задачи обучения своему предмету.

Вопрос о выборе методов проведения урока — каждодневный, практический. В его решении учителю необходимо проявить максимум самостоятельности, ибо никаких «программных указаний» по этому вопросу быть не может. Слишком разнообразны конкретные ситуации обучения.

Метод обучения нельзя оценивать как нечто очевидное и простое, лежащее на поверхности педагогической практики. В современной науке утверждается подход, согласно которому методы обучения - это исключительно сложное, многоаспектное педагогическое явление.

Что же такое метод? Метод (от греч. methodos - «исследование») - способ достижения цели, определенным образом упорядоченная деятельность; прием, способ или образ действия; совокупность приемов или операций практического или теоретического освоения действительности, подчиненных решению конкретной задачи. Существует много определений понятия «метод». Метод обучения представляет собой «систему целенаправленных действий учителя, организующую познавательную и практическую деятельность учащегося, обеспечивающую усвоение им содержания образования и тем самым достижение целей обучения». Методы обучения есть «способы взаимодействия учителя и учащихся, направленные на решение комплекса учебно-воспитательных задач» [1].

В дидактических руководствах начала XIX века методу давалось такое определение: «метод - искусство учителя направлять мысли учеников в нужное русло и организовывать работу по намеченному плану». Но видеть в методе только искусство - это значит отрицать очевидное: успешно обучают не только мастера импровизации, но и суровые логики. Многие ученые (И. П. Подласый, В.И. Загвязинский, Н.В. Басова и др.) считают, метод - главный инструмент педагогической деятельности. Именно с его помощью производится продукт обучения, осуществляется взаимодействие учителя и учащихся.

Метод преподавания не может быть изобретен, он развивается постепенно. Развитие его можно сравнить с усовершенствованием механического устройства. Как тот, так и другой, примитивные вначале, постепенно совершенствуются объединенными усилиями поколений. С точки зрения руководящей роли учителя, методы обучения можно оценивать как способы организации учебно-познавательной деятельности учащихся и управления этой деятельностью. Подчеркивая познавательную направленность существующих методов, их можно определить как способы, с помощью которых учащиеся под руководством учителя идут от незнания к знанию, от неполного и неточного знания к более полному и более точному знанию. С логико-содержательной стороны методы обучения можно оценивать как применяемый логический способ, с помощью которого учащиеся сознательно овладевают знаниями, умениями и навыками. Желая подчеркнуть содержательно-методологическую сущность методов обучения, их можно определить как форму движения содержания обучения.

Таким образом, виды современных методов обучения английскому языку: игровой метод обучения, групповой метод обучения, проектный метод обучения.

Об обучающих возможностях использования игрового метода известно давно. Многие ученые, занимающиеся методикой обучения иностранным языкам, справедливо обращали внимание на эффективность использования игрового метода. И. Хейзинга отмечал, что человеческая культура возникла и развертывается в игре, как игра. По определению М.Ф. Стронина, «игра - это вид деятельности в условиях ситуаций, направленных на воссоздание и усвоение общественного опыта, в котором складывается и совершенствуется самоуправление поведением». 
Психологические механизмы игровой деятельности опираются на фундаментальные потребности личности в самовыражении, самоутверждении, самоопределении, саморегуляции и самореализации.

В человеческой практике игровая деятельность выполняет следующие функции:

- развлекательную (это основная функция игры развлечь, доставить удовольствие, воодушевить, пробудить интерес);

- коммуникативную (освоение диалектики общения);

— диагностическую (выявление отклонений от нормативного поведения, самопознание в процессе игры);

- игротерапевтическую (преодоление различных трудностей, возникающих в других видах жизнедеятельности );

- самореализации (проявление способностей и скрытых возможностей);

- межнациональной коммуникации (усвоение единых для всех людей социокультурных ценностей $)$;

- социализации (включение в систему общественных отношений ).

Игра всегда предполагает определенного напряжения эмоциональных и умственных сил, а также умения принятия решения (как поступить, что сказать, как выиграть?). Желание решить эти вопросы обостряет мыслительную деятельность играющих. Положительным является и тот факт, что при этом ученик еще и говорит на иностранном языке. Из этого следует вывод, что игровой метод таит в себе богатые обучающие возможности. Ученики, естественно, над этим не задумываются. Для них игра, прежде всего - увлекательное занятие [2]. Этим-то она и привлекает учителей, в том числе и иностранного языка. Но значение игры невозможно исчерпать и оценить развлекательно-рекреативными возможностями. В том и состоит ее феномен, что, являясь развлечением, отдыхом, она способна перерасти в обучение, в творчество, в модель типа человеческих отношений и проявлений в труде.

Особенностью игрового метода является то, что в игре все равны. Она посильна практически каждому ученику, даже тому, который не имеет достаточно прочных знаний в языке. Более того, слабый по языковой подготовке ученик может стать первым в игре: находчивость и сообразительность здесь оказываются порой более важными, чем знания в предмете. Чувство равенства, атмосфера увлеченности и радости, ощущение посильности заданий все это делает возможность ученику преодолеть стеснительность, мешающую свободно употреблять в речи слова чужого языка, снижается боязнь ошибок, и благотворно сказывается на результатах обучения. Незаметно усваивается языковой материал, а вместе с этим возникает чувство удовлетворения, ученик может уже говорить наравне со всеми.

Использование игрового метода обучения способствует выполнению важных методических задач, таких как:
- создание психологической готовности учащихся к речевому общению;

- обеспечение естественной необходимости многократного повторения ими языкового материала;

- тренировку учащихся в выборе нужного речевого варианта, что является подготовкой к ситуативной спонтанности речи вообще [3].

Существует богатая традиция группового обучения в высшем образовании. Тысячи лет тому назад Талмуд утверждал, что для того, чтобы понимать Талмуд, один должен учить другого. Сократ обучал студентов в малых группах, втягивая их в диалог своим известным «искусством дискуссии». Еще в первом веке Қвентилиан утверждал, что студенты могут получать преимущества от обучения друг друга. Римский философ Сенека, защищая групповое обучение, сказал: «Когда ты преподаешь, ты учишься дважды». Ян Амос Коменский верил, что ученики будут получать пользу как от того, что они учатся, так и от рассказа того, чему они учат других учеников.

Групповое обучение - основа проблемного обучения. Цель группового обучения состоит в том, чтобы сделать каждого учащегося индивидуально сильнее в его собственной позиции, развить определенные коммуникативные качества личности. Участники группы изучают вместе то, что они могут в последующем лучше использовать индивидуально.

В результате исследования групповой работы были выявлены пять ключевых элементов, необходимых для организации этой работы: 1 ) позитивная взаимосвязь, 2) индивидуальная ответственность, 3) стимулирующее взаимодействие, 4) социальные навыки, 5) процесс групповой работы. Рассмотрим подробно, что значит каждый из этих элементов в работе учителя.

1. Учитель обеспечивает, чтобы каждый обучаемый понимал, что он связан с другими таким образом, что не может достичь успеха, пока другие не сделают работу. На каждом занятии выстраивается позитивная взаимозависимость таким образом, чтобы каждый ученик чувствовал свою ответственность за изучение передаваемого материала и также за то, чтобы все члены группы его изучили. Можно дополнить эту позитивную взаимозависимость, суммируя общие оценки (если 90\% всех членов группы ответили на тест правильно, то каждый получает положительную оценку), разделяя материал (давая каждому члену группы часть общей информации и требуя дополнить ее путем присоединения информации других) и введя дополнительные роли.

2. Учитель структурирует индивидуальную ответственность учеников таким образом, что деятельность каждого оценивается посредством а) индивидуального тестирования каждого учащегося; б) объяснения каждым учеником одному из своих одногруппников, что он выучил; в) наблюдения за каждой группой и документирования вклада каждого члена группы.

3. Учитель обеспечивает стимулирование учащимся успеха друг друга (помогая, способствуя, поддерживая, 
стимулируя и одобряя усилия друг друга). Организованный таким образом когнитивный процесс становится вербально объясняющим, как именно решать проблемы, как учить каким-то знаниям своих товарищей и как связывать настоящее учение с предыдущим. Это ведет к таким внутриличностным процессам, как вызов одного объяснения другим, одних решений другими, моделированию и фасилитации усилий к учебе. Вербальные и невербальные реакции других членов группы обеспечивают важную обратную связь деятельности ученика. Все участники также получают возможность узнать друг друга как на личностном, так и на профессиональном уровне. Для реализации взаимодействия в группе, наиболее оптимальные группы из $4-5$ участников.

4. Учитель учит учащихся необходимым социальным навыкам и обеспечивает соответствующее их использование. Успех работы в группе требует внутриличностных и групповых навыков. Навыкам лидерства, принятию решения, созданию доверия, коммуникации и управлению конфликтами надо обучать также целенаправленно и точно, как и академическим навыка.

5. Учитель обеспечивает условия, чтобы у учеников было время включиться в групповой процесс: определение способов совершенствовать процессы, которые участники использовали для максимилизации своего собственного обучения и обучения друг друга. Учащиеся фокусируются на постоянном совершенствовании этих процессов путем: а) описании того, какие действия были более или менее полезны в обеспечении эффективных рабочих взаимоотношений и того, все ли члены группы достигли своих учебных целей; б) принятия решений о том, какие модели поведения следует далее развивать, а какие изменить. Результатом процесса групповой работы может быть:

- направление учебного процесса по пути его упрощения;

— избавление от непрофессиональных и неподобающих действий;

- постоянное усовершенствование навыков командной работы учащихся [4].

Группы учащихся формируются учителем до урока, разумеется, с учетом психологической совместимости. При этом в каждой группе должны быть ученики с разной степенью владения иностранным языком. Если группа в течение нескольких уроков работает слаженно, дружно, нет необходимости менять ее состав. Если работа по каким-то причинам не складывается, состав группы целесообразно менять от урока к уроку.

Современная групповая работа, как правило, начинается с фронтальной работы, в ходе которой преподаватель ставит проблемы и дает задания группам: единые или дифференцированные. Именно дифференцированная групповая работа вносит новые элементы во фронтальную работу (работу учителя со всеми учениками одновременно). Фронтальная постановка проблемы и последующее расчленение темы и разделение между группами задач соз- дают новую ситуацию: все ученики узнают о роли каждой группы, таким образом, устанавливаются твердые взаимные ожидания, а у группы отдельных учащихся возникает чувство долга и ответственности перед всеми Оценка за выполнение общего задания ставится одна на группу. Это не обязательно отметка в баллах. Могут быть разные виды поощрения, оценки деятельности всей группы. И еще один момент следует учитывать при оценивании работы группы. Иногда совсем не обязательно, чтобы группы соревновались друг с другом, так как они могут иметь разную «Планку» и им можно давать разное время для ее достижения.

В целях управления умственной деятельностью учащихся учитель должен знать, какие ошибки допустили члены тех или иных групп, какую часть задания они смогли выполнить за отведенное им время. До перехода к фронтальной работе учитель должен представить себе, как отдельные группы справились с полученным заданием. Эти сведения учитель частично получает в процессе наблюдения за работой групп, более точное представление он получает во время последующей фронтальной работы, в ходе совместного коллективного анализа результатов проделанной работы. Все это позволяет учителю направлять дальнейший ход усвоения материала. Ученики сами также получают необходимую обратную связь для продолжения работы [5]. Конечно, на основе этих данных учитель не может оценить успехи отдельных учеников. В этом и нет особой необходимости в ходе упражнения и усвоения нового материала. Текущая и заключительная проверка знаний в конце больших разделов материала происходит строго индивидуально.

Таким образом, при современной групповой работе учебная деятельность каждого ученика не только не превращается в анонимную, обезличенную, но, напротив, ответственность каждого отдельного ученика возрастает. Он ответственен перед членами своей группы и отчитывается индивидуально перед учителем.

Практика показывает, что вместе учиться не только легче и интереснее, но и значительно эффективнее. При этом важно, что эта эффективность касается не только академических успехов учеников, их интеллектуального и нравственного развития. Помочь друг другу, вместе решить любые проблемы, разделить радость успеха или горечь неудачи - естественно для процесса обучения в группе. Учиться вместе, а не просто выполнять что-то вместе - вот что составляет суть данного метода. Большинство школ испытывают сегодня немало трудностей при обучении иностранному языку. Не имея возможности использовать полученные по иностранному языку знания вне класса, учащиеся теряют интерес к его изучению. Поэтому целесообразно применять метод проектов в учебно-воспитательном процессе средней школы, который нашел широкое применение во многих странах мира главным образом потому, что он позволяет органично интегрировать знания учащихся из разных областей при решении одной проблемы, дает возможность применять по- 
лученные знания на практике, генерируя при этом новые идеи. Этот метод помогает оптимизировать процесс обучения в самой обычной общеобразовательной школе.

Но если мы говорим о методе проектов, то имеем в виду способ достижения дидактической цели через детальную разработку проблемы. Разработка должна завершаться вполне реальным, осязаемым практическим результатом, оформленным тем или иным образом.

В основу метода проектов положена идея, составляющая суть понятия «проект», его прагматическая направленность на результат, который можно получить при решении той или иной практически или теоретически значимой проблемы [6]. Этот результат можно увидеть, осмыслить или применить в реальной практической деятельности. Чтобы добиться такого результата, необходимо научить школьников самостоятельно мыслить; привлекать для выполнения проекта знания из различных областей; прогнозировать результаты и возможные последствия определенных вариантов решения; работать слажено, помогая друг другу.

Метод проектов предполагает использование широкого спектра проблемных, исследовательских, поисковых методов, ориентированных четко на реальный практический результат, значимый для каждого ученика, участвовавшего в разработке проекта, а также разработку проблемы целостно с учетом различных факторов и условий ее решения и реализации результатов. Метод проектов позволяет создавать на уроке иностранного языка исследовательскую творческую атмосферу, где каждый ученик вовлечен в активный познавательный процесс на основе методики сотрудничества.

Группы учащихся формируются с учетом психологической совместимости, при этом в каждую группу включаются ученики с разной степенью владения иностранным языком. Группа выбирает одно задание, но при его выполнении происходит распределение ролей. Қаждый ученик получает самостоятельный участок работы в проекте. В процессе выполнения проекта учащиеся приходят к выводу, что от успеха каждого зависит успех всего проекта, поэтому каждый участник активно включается в поиск новой информации, иначе это можно назвать «добывание знаний». А это большой стимул к активному усвоению знаний.

Овладевая культурой выполнения проектных заданий, ученик приучается творчески мыслить, самостоятельно планировать свои действия, прогнозируя возможные варианты решения стоящих перед ним задач, реализовывать усвоение им средства и способы работы [7]. Работая над проектом, ученики учатся работать в «команде», ответственно относиться к выполнению своего задания, оценивать результаты своего труда и труда своих товарищей. Он также выступает и как социальное лицо, соотносящее свои личные интересы с общественными, и как творческое лицо, побуждающее предложить новые решения отдельных жизненных проблем.

Следует помнить, что для того, чтобы выполнить все задания проекта учащиеся должны владеть определенными интеллектуальными, творческими и коммуникативными умениями. К ним можно отнести умение работать с текстом (выделять главную мысль, вести поиск нужной информации), анализировать информацию, делать обобщения и выводы, работать с различными справочными материалами. K творческим умениям можно отнести умение генерировать идеи (для этого требуются знания в различных областях).

Задачей обучения различным видам речевой деятельности и является формирование многих из вышеназванных умений.

Таким образом, для грамотного использования метода проектов требуется значительная подготовка, которая осуществляется, разумеется, в целостной системе обучения в школе (подразумевается, что не только в обучении иностранному языку), причем совсем необязательно, чтобы она предваряла работу учащихся над проектом. Такая подготовительная работа должна проводиться постоянно, систематически и параллельно с работой над проектом.

В современных условиях необходимо больше внимания уделять развитию творческих способностей учащихся, их познавательных потребностей и интересов. Обучение как руководство предполагает преподнесение, сообщение учителем определенных знаний и управление процессом их овладения всеми учащимися класса. Поэтому учитель не только преподносит информацию по своему предмету, но и планирует, организовывает и контролирует учебную деятельность ученика, развивает навыки учебного труда, мышление, способности, умение применять знания на практике.

Метод обучения представляет собой «систему целенаправленных действий учителя, организующую познавательную и практическую деятельность учащегося, обеспечивающую усвоение им содержания образования и тем самым достижение целей обучения». Методы обучения есть «способы взаимодействия учителя и учащихся, направленные на решение комплекса учебно-воспитательных задач».

С логико-содержательной стороны методы обучения можно оценивать как применяемый логический способ, с помощью которого учащиеся сознательно овладевают знаниями, умениями и навыками. Желая подчеркнуть содержательно-методологическую сущность методов обучения, их можно определить как форму движения содержания обучения.

Литература:

1. Бабанский, Ю. К. Методы обучения в современной общеобразовательной школе. - M., 1995

2. Гальскова, Н.Д. Современная методика обучения иностранным языкам // М.: Аркти-Глосса, 2000. 
3. Зимняя, И.А., Сахарова Т.Е. Проектная методика обучения английскому языку// Иностранные языки в школе., 1991 .

4. Конышева, А. В. Современные технические средства обучения иностранному языку. Методическое пособие. Новополоцк, 1999.

5. Пассов, Е. И. Урок иностранного языка в средней школе. - М.: Просвещение, 1991.

6. Пидкасистый, П.И., Хайдаров Ж. С. Технология игры в образовании. - М.: РПА, 1996.

7. Полат, Е. С. Метод проектов на уроках иностранного языка // Иностранный язык в школе. 2000. № 2 , № 3.

\title{
Модель методики внеклассной работы по курсу «0сновы безопасности жизнедеятельности», способствующая повышению качества знаний учащихся 10-11 классов по экологической безопасности
}

\author{
Абрамова Вера Юрьевна, кандидат педагогических наук, доцент; \\ Елизарова Ирина Сергеевна, кандидат педагогических наук, преподаватель \\ Российский государственный педагогический университет им. А. И. Герцена (г. Санкт-Петербург)
}

\section{Model of a technique of out-of-class work on the course «Fundamentals of Health and Safety», promoting improvement of quality of knowledge of pupils of 10-11 classes on ecological safety}

В статье рассматривается модель методики внеклассной работы по курсу «Основы безопасности жизнедеятельности» с позиции интегрированного и личностно-деятельностного подходов. Описывается система принципов, представленная группами, каждая из которых регулирует деятельность либо содержание определенных элементов системы внеклассной работы по курсу «Основы безопасности жизнедеятельности». Определены основные функции и выделены компоненты модели методики внеклассной работы по курсу «Основы безопасности жизнедеятельности», способствующие системному повышению качества знаний учащихся 10-11 классов по экологической безопасности.

Ключевые слова: курс «основы безопасности жизнедеятельности», экологическая безопасность, внеклассная работа, интегрированный и личностно-деятельностный подходь.

In article the model of a technique of out-of-class work on the course «Fundamentals of Health and Safety» from a position of the integrated and personal and activity approaches is considered. The system of the principles presented by groups is described, each of which regulates activity or the maintenance of certain elements of system of out-of-class work on the course «Fundamentals of Health and Safety». The main functions are defined and components of model of a technique of out-of-class work on the course «Fundamentals of Health and Safety», promoting improvement of quality of knowledge of pupils of 10-11 classes on ecological safety are allocated.

Keywords: course of «fundamentals of health and safety», ecological safety, the out-of-class work, the integrated and personal-activity approaches.

$\mathrm{B}$ ажность внеклассной работы по курсу «Основы безопасности жизнедеятельности» в целях повышения качества знаний учащихся 10-11 классов по экологической безопасности обусловливается тем, что перед старшеклассниками стоит проблема экологически безопасного существования в современном и постоянно меняющемся мире [1, 2, 5]. Следовательно, существует необходимость в разработке модели методики организации внеклассной работы по экологической безопасности в курсе «Основы безопасности жизнедеятельности» в старших классах для повышения качества знаний учащихся по данному предмету.
При построении модели методики внеклассной работы по курсу «Основы безопасности жизнедеятельности», способствующей повышению качества знаний учащихся 10-11 классов по экологической безопасности, важным является определение научно-методических основ процесса организации внеклассной работы.

Проведенный анализ педагогической и методической литературы показал $[3,4,6]$, что на организацию внеклассной работы учащихся 10-11 классов по курсу «Основы безопасности жизнедеятельности»в целях повышения качества знаний по экологической безопасности 
оказывают влияние такие тенденции развития педагогической науки, как гуманизация, дифференциация, интеграция.

При определении принципов в процессе нашего исследования учитывались эффективные способы и средства внеклассной работы по курсу «Основы безопасности жизнедеятельности» для диагностики и измерения качества усвоения знаний по экологической безопасности на различных этапах организации внеклассной работы.

При создании методики внеклассной работы по курсу «Основы безопасности жизнедеятельности», способствующей повышению качества знаний учащихся по эко логической безопасности мы опирались на: теорию познания, регламентирующую развитие способностей учащихся; теорию учебно-познавательной деятельности учащихся; идею всестороннего развития личности ребенка на основе возрастающей активности самой личности; идею предоставления ребенку максимальной свободы выбора форм и средств самореализации при ведущей роли отношений творческого сотрудничества; идею усиления мотивации к творчеству и познанию за счет разнообразной разносторонне развивающей творческой деятельности.

При создании системы принципов нами использовались дидактические и методические принципы, обусловливающие сущность конкретных этапов внеклассной работы по курсу «Основы безопасности жизнедеятельности»с учащимися 10-11 классов, направленные на повышение качества знаний по экологической безопасности. Система принципов представлена группами, каждая из которых регулирует деятельность либо содержание определенных элементов системы внеклассной работы по курсу «Основы безопасности жизнедеятельности».

Первая группа принципов направлена на отбор оптимального содержания внеклассной работы по предмету и организации педагогической коммуникации. К данной группе относятся принципы: доступности, прочности, взаимосвязи внеклассных и урочных занятий по курсу «Основы безопасности жизнедеятельности», вариативности.

Вторая группа принципов направлена на оптимальную регуляцию деятельности педагога и его отношение к организации внеклассной работы по курсу «Основы безопасности жизнедеятельности» с учащимися 10-11 классов. К данной группе относятся принципы: гуманистической направленности, учета возрастных и индивидуальных особенностей школьников, практичности, систематичности и последовательности.

Третья группа принципов направлена на организацию различных видов деятельности учащихся во внеклассной работе по курсу «Основы безопасности жизнедеятельности». К данной группе относятся принципы: развития активности и сознательности учащихся в процессе внеклассной работы, самостоятельности, сочетания коллективных, групповых и индивидуальных организаци- онных форм, функциональной обусловленности деятельности.

Учитывая дидактические и методические принципы, нами определены общие требования к методике внеклассной работы по курсу «Основы безопасности жизнедеятельности», направленные на повышение качества знаний учащихся 10-11 классов по экологической безопасности:

- использование мотивов и развитие интересов к выполнению заданий на внеклассных занятиях;

- разработка системы работ исследовательского характера, направленной на повышение качества знаний учащихся по экологической безопасности;

- применение индивидуальных и групповых форм деятельности, учитывающих индивидуальные возможности и способности учащихся.

В процессе исследования определено, что комплексное использование дидактических и методических принципов является основой для построения модели методики организации внеклассной работы учащихся по курсу «Основы безопасности жизнедеятельности» в целях повышения качества знаний по экологической безопасности.

При включении учащихся во внеклассную работу по курсу «Основы безопасности жизнедеятельности» для повышения качества знаний учащихся 10-11 классов по экологической безопасности выявляются следующие закономерности.

- Возрастает активность личности.

Повышению социальной активности индивида способствует усвоение таких компонентов культуры, как опыт творческой деятельности и опыт эмоционально-ценностных отношений. Познавательную активность психологи рассматривают как одну из сущностных характеристик личности, отражающую ее устойчивые интересы, сформированность эмоционально-волевой сферы и практическую подготовленность, обусловленную соответствующими знаниями, умениями и навыками.

- $\mathrm{У}$ школьников формируется творческий стиль жизнедеятельности.

Этому способствуют следующие условия: признание безусловной ценности индивида; создание обстановки, в которой отсутствует внешнее оценивание; понимание и сопереживание; полная свобода символического выражения. Считаем, что полная реализация этих условий возможна лишь в рамках внеклассной работы.

В связи с имеющимся в системе школьного образования противоречием между социально обусловленной потребностью организации внеклассной работы и фактическим отсутствием адекватной методики организации внеклассной работы, способствующей повышению качества знаний учащихся по экологической безопасности, появилась объективная необходимость в новых подходах к организации внеклассной работы по курсу «Основы безопасности жизнедеятельности».

В рамках нашего исследования цель каждого внеклассного занятия формируется с позиции каждого конкрет- 
ного ученика и всей группы в целом. Также в процессе организации и проведения внеклассных занятий по курсу «Основы безопасности жизнедеятельности» учитываются возрастные, индивидуально-психологические особенности школьников. Этот учет осуществляется через содержание и форму внеклассных занятий, через характер общения с учеником, возможность выбора учащимися интересующих их видов работ.

Следовательно, внеклассная работа по экологической безопасности должна быть наполнена таким материалом, который в отдельных случаях будет представлять общественный интерес. Данный подход реализуется за счет включения в содержание внеклассной работы по экологической безопасности опыта переживания, ситуаций нравственного выбора, самоанализа и самооценки своих достижений, раскрытие жизненно важных практических умений.

Резюмируя вышеизложенное, можно отметить, что каждый из рассмотренных нами подходов находит свое отражение в современной системе школьного образования.

Использование интегративного и личностно-деятельностного подходов при разработке теоретической модели организации внеклассной работы по курсу «Основы безопасности жизнедеятельности» с целью повышения качества знаний учащихся 10-11 классов по экологической безопасности позволит раскрыть взаимосвязь составляющих ее компонентов, определить характер взаимодействия учителя и учащихся. Данные подходы определяют содержание и этапы внеклассной работы по курсу «Основы безопасности жизнедеятельности», а также конкретизируют функции, определяющие структуру разрабатываемой модели.

Модель методики внеклассной работы по курсу «Основы безопасности жизнедеятельности», способствующая повышению качества знаний учащихся 10-11 классов по экологической безопасности обусловлена следующими функциями: социальная, осуществляющая формирование различных компетенций с учетом потребностей личности, общества и школьного образования; прогностическая, обеспечивающая использование прогностической информации для определения долгосрочной перспективы формирования личности ученика; мотивационная, обеспечивающая формирование мотивации при использовании компьютерных средств, методов и методических приемов обучения; коммуникативная, реализующая перевод обучаемого на позицию субъекта учебно-познавательной деятельности; исследовательская, направленная на овладение учащимися методами научно-познавательной деятельности и участие их в проведении экспериментальных исследований.

Учитывая перечисленные компоненты, нами экспериментально разработана модель методики внеклассной работы по курсу «Основы безопасности жизнедеятельности», способствующая повышению качества знаний учащихся 10-11 классов по экологической безопасности (рис. 1).

Определяя структуру методики внеклассной работы по курсу «Основы безопасности жизнедеятельности» в целях повышения качества знаний учащихся 10-11 классов по экологической безопасности выделяем следующие компоненты: целевой, содержательный, процессуальный, результативно-оценочный.

Целевой компонент модели является главным и детерминирующим фактором функционирования и развития разработанной методики, отражает организацию учебно-воспитательного процесса по курсу «Основы безопасности жизнедеятельности», включает в себя цель и задачи повышения качества знаний учащихся по экологической безопасности в условиях внеклассной работы.

Содержательный компонент модели отражает содержание выделенных содержательно-методических комплексов внеклассных мероприятий и предполагает применение усвоенных учащимися знаний по экологической безопасности в практико-ориентированной деятельности. На формирование содержания знаний в области экологической безопасности оказывают влияние факторы: цели, которые общество ставит перед школой; специфика учебной дисциплины; конкретные цели изучения экологической безопасности; реальные возможности повышения качества знаний учащихся в курсе «Основы безопасности жизнедеятельности» в условиях внеклассной работы; дидактические и методические принципы; психолого-возрастные особенности старшеклассников; возможности учащихся; потребности личности в изучении данного материала.

Процессуальный компонент модели отражает процессуальную сущность обучения. Этот компонент играет определяющую роль, обеспечивая целостность методики, функционирование и развитие основных ее элементов. Данный компонент модели реализуется совокупностью методов, средств и приемов, обеспечивающих организацию внеклассной работы по курсу «Основы безопасности жизнедеятельности».

Рассматриваемый компонент модели позволяет использовать совокупность методов и приемов, влияющих на успешность усвоения знаний учащимися по экологической безопасности: приемы актуализации субъективного опыта учащихся; игровые методы; методы диалога и полилога, обеспечивающие перевод индивидуальных видов деятельности учащихся в деятельность совместную, объединенную единой целью; приемы создания ситуации индивидуального и коллективного выбора; рефлексивные методы и приемы, направленные на организацию осознания учениками собственной деятельности; методы диагностики и самодиагностики.

Результативный-оценочный компонент модели предполагает оценку педагогами и самооценку учениками достигнутых в процессе обучения результатов, установление соответствия их поставленным учебно-воспи- 
тательным задачам, выявление причин обнаруживаемых отклонений, проектирование новых задач, учитывающих также и необходимость восполнения обнаруженных пробелов в знаниях и умениях. Результативно-оценочный компонент модели включает: знания в области экологической безопасности, исследовательские умения, мотивы, ценности и познавательный интерес старшеклассников к предмету.

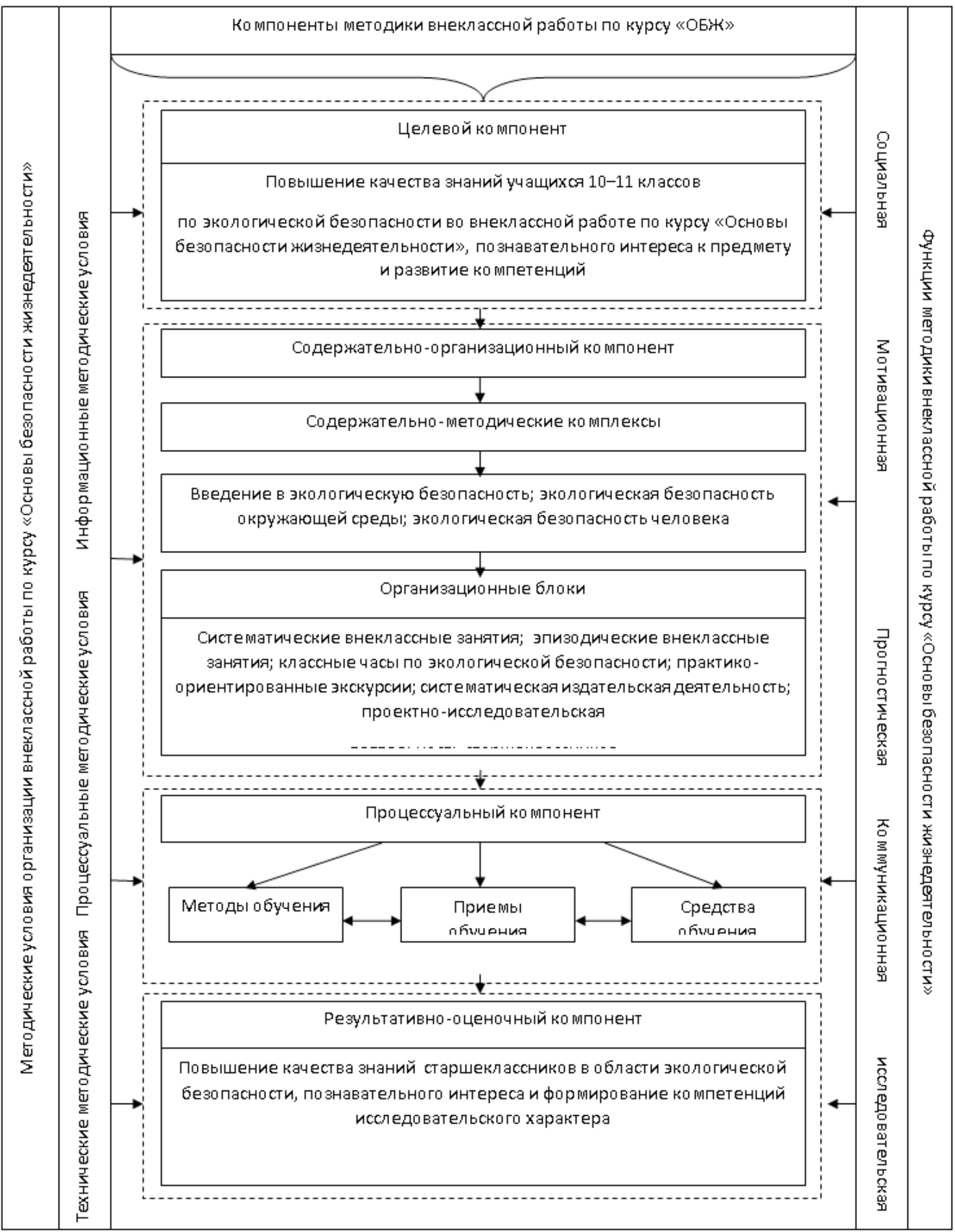

Рис. 1. Модель методики внеклассной работы по курсу «Основы безопасности жизнедеятельности», способствующая повышению качества знаний учащихся 10-11 классов по экологической безопасности 
Представленная модель является системой, включающей указанные компоненты, позволяющие осуществлять развитие, корректирование и оценивание качества знаний учащихся по экологической безопасности с учетом целей и задач школьного образования в области безопасности жизнедеятельности.

В процессе конструирования модели методики учитывались основные методические закономерности:
— преемственность усвоения знаний в процессе урочных и внеклассных занятий по курсу «Основы безопасности жизнедеятельности»;

- взаимосвязь учебно-познавательной и предметно-практической деятельности учащихся в процессе внеклассных занятий;

- перенос усвоенных учащимися теоретических знаний по экологической безопасности на практику.

Литература:

1. Киселева, Э.М., Гаврилова Л.А. Возможности курса основы безопасности жизнедеятельности в формировании знаний по экологической безопасности школьников//Вестник Орловского государственного университета. Серия: Новые гуманитарные исследования. 2013.№ 5 (34). С.97-101.

2. Костецкая, Г.А. Курс «Основы безопасности жизнедеятельности» в экологическом образовании школьников: возможности, проблемы и пути решения//Астраханский вестник экологического образования. 2014.№ 2 (28). C.97-102.

3. Попова, Р.И. Методические основы формирования исследовательских умений учащихся при изучении курса ботаники диссертация на соискание ученой степени кандидата педагогических наук/Санкт-Петербург, 2000.

4. Попова, Р.И., Авдеева Н. В. Возможности компетентностно-ориентированного подхода к организации учебно-исследовательской деятельности учащихся при изучении курса ОБЖ // Мир науки, культуры, образования. 2010.№ 5. С.73-76

5. Попова, Р.И., Силакова О.В. Методиическая подготовка магистров педагогического образования в области безопасности жизнедеятельности к организациии внеклассной работы с учащимися // Мир науки, культуры, образования. 2011.№ 5.С.63-66.

6. Силакова, О.В.Методика развития эколого-экономических знаний при обучении общей биологии диссертация на соискание ученой степени кандидата педагогических наук/Санкт-Петербург, 2006.

\title{
Педагогический потенциал информационных технологий в профессиональной подготовке будущих учителей химии
}

\author{
Адаев Иван Анатольевич, аспирант \\ Чувашский государственный педагогический университет имени И. Я. Яковлева (г. Чебоксары)
}

$\prod^{\prime}$ роисходящие в стране социально-экономические преобразования и модернизация системы профессионального образования вызвали необходимость совершенствования работы педагогического вуза по подготовке будущих учителей, в т.ч. и будущих учителей химии. Теория и практика современного педагогического образования имеет богатый опыт подготовки педагогических кадров, в т.ч. и с использованием информационных технологий. В последние годы появились исследования, посвященные использованию современных средств информационных технологий в профессиональной подготовке будущих учителей химии. Так, Ю.В. Гавронская предлагает использовать компьютерные программы при опосредованном обучении для контроля поисковой деятельности студентов на интерактивной лекции [1, с. 165].

Н.А. Шкильменская, говоря о реализации функций информационно-коммуникационных технологий, отмечает круг задач, решаемых с их помощью, среди которых: изучение и закрепление нового материала; проведение лабораторных работ или практикумов; иллюстрация нового материала; самообразование и контроль [6, с. 64].

С.И. Гильманшина, С. С. Космодемьянская считают, что компьютерные технологии являются в школе одним из средств реализации других (тех или иных) педагогических технологий, применяемых в каждом конкретном случае [2, с. 104].

М.Е. Соловьев, М.М. Соловьев предлагают конкретные варианты применения информационных технологий в обучении химии, а именно универсальные химические пакеты программных средств ChemOffice и HyperChem, являющиеся на сегодняшний день одними из популярных во многих химических лабораториях различных стран мира. Указанные программные средства помогают визуализировать пространственную структуру молекул, прогнозировать физико-химические свойства органических соединений, исследовать конформацию 
и динамику молекул методами классической механики, моделировать межмолекулярные взаимодействия и пр. [4].

А. Г. Тихобаев подчеркивает эффективность интерактивных технологий в обучении, которые он классифицирует по участникам диалога следующим образом: человек-человек (деловые и ролевые игры, работа в группах, дискуссия, мозговой штурм и т.д.); человек-машина (виртуальная реальность, компьютерные игры, интерактивные средства и т.д.); человек-машина-человек (дистанционное обучение, локальные телекоммуникационные технологии, компьютерное тестирование и т.д.) [5, c. 82]. Автор предлагает использовать программу Model ChemLab (симулирование различных химических процессов), относящуюся, с его точки зрения, к технологиям виртуальной реальности.

Козма (R. B. Kozma) и Андерсон (R. E. Anderson), pacкрывая педагогический потенциал, отмечают, что информационные технологии:

- способствуют целенаправленности, активности, самостоятельности студентов; их ответственности за собственное обучение; помогают оценивать свои успехи и/ или успехи других студентов;

- способствуют формированию у студентов умений и навыков поиска, систематизации и анализа информации, а также общения и выражения мыслей с помощью различных технических средств;

- способствуют организации проектной деятельности студентов, особенно в случаях моделирования сложных объектов;

- могут быть средством организации индивидуального плана обучения, позволяющего студентам освоить учебный материал с учетом их способностей, интересов и уровня знаний;

- способствуют объективной оценке, не зависящей от пола, национальности, социального происхождения студентов; помогают организовать дистанционное обучение;

- помогают привлечь в образовательный процесс родителей, ученых, бизнесменов, тем самым выводя процесс обучения за пределы школы и класса;

- способствуют знакомству и общению студентов с представителями разных наций и культур [8, с. 15].

По определению ЮНЕСКО, информационные технологии - это комплекс взаимосвязанных научных, технологических, инженерных наук, изучающих методы эффективной организации труда людей, занятых обработкой и хранением информации с помощью вычислительной техники и методы организации и взаимодействия с людьми и производственным оборудованием, их практические применение [7]. В настоящее время в педагогической науке обобщается педагогический опыт применения информационных технологий. Ученые считают, что при всех возможностях современных информационных технологий, целью информатизации образования является не сам факт их использования в обучении, а повышение качества образовательной системы через их внедрение и распространение. Среди форм использования инфор- мационных технологий в образовательном процессе учеными выделяются две основные:

- обучение методам использования информационных технологий;

— обучение с помощью информационных технологий.

Современные реалия таковы, что мультимедийные средства обучения (и главный из них - электронный учебник) выходят на первый план в вузовской системе. Электронные учебники создаются сегодня при помощи разных технологий, использующих традиционные алгоритмические языки, мультимедиасредства, гипермедиасредства. Так, некоторые разработчики используют веб-технологии. В этом случае электронный учебник представляет собой сложные гипертексты с включенными в них иллюстрациями, справочными материалами. В других случаях создаются инструментальные оболочки, которые наполняются текстовыми и графическими материалами. Н.Н. Елистратова в своей работе приводит несколько определений, среди которых электронным учебником признается: компьютерное педагогическое программное средство; электронный учебный курс; комплекс информационных, методических и программных средств: основное учебное электронное издание. Она разводит понятия «электронный учебник» и «электронное учебное пособие». Основная разница между этими понятиями заключается в том, что в учебник предназначен для чтения всей представленной в нем информации, а материал пособия может изучаться выборочно [3].

Анализ вышеуказанных источников был нам необходим для разработки электронного учебного пособия. Таким образом, мы определили для себя требования к форме представления учебного материала:

- учебный материал представляется в виде блоков или модулей;

- на экране компьютера одномоментно отображается только та информация, которая нужна пользователю для усвоения темы, при этом у пользователя сохраняется возможность доступа к другой информации;

- выразительные средства (анимация, выделение цветом, звук, видео) применяются только в случаях целесообразности. Например, для характеристики фрагмента урока одного текстового описания недостаточно, нужно видео, при этом если в видеосюжете звук плохо различим, то можно включить пояснения в виде субтитров;

- в тексте используются гиперссылки;

— в пособии используются обучающие тесты, что обеспечивает интерактивность и диалогичность процесса обучения.

Разработанное нами учебное пособие имеет древовидную структуру с членением на пункты и подпункты. На странице пособия слева располагается колонка с оглавлением пособия, справа - поле, в котором отображается содержание учебного материала. Разработка пособия велась в программном обеспечении Adobe Dreamweaver. Данная программа обладает широкими возможностями 
по созданию и редактированию сайтов разного уровня сложности и назначения.

Технологической базой учебного пособия являются web-технологии, такие, как язык гипертекстовой разметки (HTML), прототипно-ориентированный сценарный язык программирования javascript, а также технология каскадных таблиц стилей (CSS).

Главная страница и все подстраницы сайта представляют собой html-файлы, связанные гиперссылками через меню сайта. Меню (содержание) учебника создано с помощью языка программирования javascipt, что обеспечивает его интерактивность, простоту в изменении содержимого меню и низкую требовательность всего сайта к вычислительным ресурсам устройства, на котором отображается учебное пособие (персонального компьютера, планшета, смартфона). Каскадные таблицы стилей (CSS) используются для приведения содержимого сайта к единому внешнему виду без необходимости правки каждой страницы с учебным материалом по отдельности.

Основное окно учебного пособия состоит из четырех блоков: заголовка по верхнему краю страницы, в котором находятся логотип учебника, его название и основное описание; интерактивного содержания-меню в левой части, которое откликается на действия пользователя - наведение курсора подсвечивает элемент меню, нажатие открывает или закрывает его содержание; основной части страницы справа, которая занимает большую часть экрана, и в которой отображается информация о сайте, учебный материал, вопросы для освоения и обучающие упражнения.

Обучающие тесты разрабатывались нами в программном обеспечении HotPotatoes, которое представляет собой комплект средств для разработки тестовых упражнений пяти видов - JCloze (упражнение типа «вставьте недостающее слово»), JCross (головолом- ка-кроссворд), JMatch (упражнения на поиск соответствий), JMix (упражнение на восстановление порядка предложений) и JQuiz (упражнение-тест с выбором одного или нескольких вариантов, также возможен вариант с коротким ответом). Қаждому варианту ответа назначается комментарий, который затем выводится во всплывающем окне вместе с информацией о прогрессе по всему упражнению. Это дает возможность коррекции знаний при изучении модуля. Программное обеспечение HotPotatoes также предусматривает возможность экспорта готового задания в файл формата HTML, который затем очень легко встраивается в электронный учебник.

Как показало наше теоретическое исследование, информационные технологии направлены на организацию таких способов деятельности студентов, как: активный и мотивированный поиск информации в условиях неопределенной ситуации; дивергентное и конвергентное мышление; обнаружение проблемы и выработка гипотезы; наблюдение и эксперимент; анализ полученных результатов, оценка и прогнозирование на их основе развития ситуации. При проведении экспериментальной работы мы использовали информационные технологии в качестве средств визуализации лекционного материала; средства создания медиа-текстов; средства организации общения.

На наш взгляд, перспектива исследовательской деятельности по данной проблеме может предполагать такие направления работы, как выявление причинно-следственных связей и закономерностей процесса профессиональной подготовки будущих учителей химии; выявление путей совершенствования мониторинга этого процесса и подбор оптимальных средств диагностики; модернизация информационных технологий, позволяющих эффективно формировать профессиональные компетенции у будущих учителей химии и др.

Литература:

1. Гавронская, Ю.Ю. Технология интерактивного обучения химическим дисциплинам в педагогическом вузе // Известия РГПУ им. А. И. Герцена. - 2008. - № 52. - с. 157-692.

2. Гильманшина, С.И. Формирование профессионального мышления будущих учителей на основе компетентностного подхода: дис... д-ра пед. наук: 13.00.01 / С. И. Гильманшина; Институт педагогики и психологии профессионального образования РАН. - Казань, 2008. - 559 с.

3. Елистратова, Н.Н. Электронный учебник как средство и условие мультимедийного обучения в педагогике высшей школы / Н.Н. Елистратова // Вестник Рязанского государственного университета им. С.А. Есенина. - 2010. - № 27. - с. 15-22.

4. Соловьев, М.Е. Компьютерная химия: для студентов и преподавателей / M. Е. Соловьев, М. М. Соловьев.М.: Солон-Пресс, 2005.- 535 с.

5. Тихобаев, А. Г. Интерактивные компьютерные технологии обучения / А. Г. Тихобаев // Вестник Томского государственного педагогического университета. - 2012. - № . 8. - c. 81-84.

6. Шкильменская, Н.А. Основные функции современных информационно-коммуникационных технологий в условиях гуманитаризации образования / Н.А. Шкильменская // Известия РГПУ им. А. И. Герцена. - 2008. № 83. - c. 58-69.

7. Heine, P. UNESCO ICT Competency Framework for Teachers / Paul Hine. Paris: UNESCO, 2013. - 92 p.

8. Kozma, R.B. and Anderson, R.E. (2002). Qualitative case studies of innovative pedagogical practices using ICT, Journal of Computer Assisted Learning, 18, 387-394. 


\section{Формирование жизненных стратегий у учащихся}

Алешкина Ольга Владимировна, учитель информатики мБОУ «СОШ № 24» (г. Астрахань)

Данная статья посвящена особенностям формирования жизненных стратегий учащихся.

Ключевые слова: стратегии, адаптация.

$A_{\mathrm{s}}^{k}$ ктуальность данного исследования заключается том, что школьное образование сегодня переориентировано на становление и развитие образованной, компетентной и просвещённой личности, способной к осознанному и ответственному решению разноплановых задач в условиях неопределённости. Речь идёт об образовании, которое развивает личность как индивидуальность, самостоятельную в проектировании жизненных и профессиональных задач, в порождении личностных смыслов, а не личность, способную мыслить и действовать лишь по шаблону «как учили и выучили.

Предмет исследования - жизненные стратегии.

Объект исследования - формирование жизненных стратегий у учащихся.

Цель исследования - рассмотреть особенности формирования жизненных стратегий у учащихся.

Главная цель образования сегодня - формирование человека не только знающего и умеющего, но и демонстрирующего эффективное поведение в различных областях жизнедеятельности. Современная школа должна не только научить, дать ученику академические знания, но и воспитать человека успешного, т.е. компетентного.

Под жизненной стратегией понимается выбор перспективы развития и прохождения своего жизненного пути, осуществляемый по индивидуальной технологии, направленный на благополучие, успех и самореализацию.

В основе построения жизненных стратегий развития лежит естественное стремление человека к самореализации. Самореализация (самоактуализация) личности это духовная потребность человека в проявлении собственного внутреннего потенциала.

Стратегия жизни разных школьников состоит в том, что одному удается сразу определить свою основную жизненную линию, другой первоначально может видеть несколько перспектив, направлений своей самореализации и хочет сначала попробовать себя в разных сферах, а затем уже выбрать главное направление. Именно поэтому современная школа должна предоставить ученику как можно больше площадок для самовыражения.

В современной отечественной социально-психологической литературе можно выделить два основных подхода к исследованию жизненных стратегий, различающихся по тому, что выбирается в качестве основания для их типологизации. Первый подход (Н.Ф. Наумова и др.) характеризуется тем, что за основу типологизации жизненных стратегий берется тип социальной адаптации человека. Так, Н.Ф. Наумова выделяет три типа стратегий в зави- симости от социальных и личностных функций, выполняемых человеком в обществе переходного периода:

1) стратегия успешной внешней адаптации;

2) стратегия эффективной внутренней адаптации;

3) стратегия выживания.

Стратегия успешной внешней адаптации ориентирована на настоящее и ближайшее будущее, идентификация направлена на первичные (семья и др.) и профессиональные группы. Стратегия эффективной внутренней адаптации ориентирована на прошлое и отдаленное будущее, идентификация направлена на большие группы - страна, народ. И, наконец, третья стратегия - стратегия выживания характеризуется невысоким статусом и ухудшающимся материальным положением индивида, который идентифицирует себя с группами людей похожей судьбы.

Процесс формирования жизненных стратегий связан с социализацией личности, которая включает в себя механизм идентификации (типизации) и индивидуализации. Механизм типизации связан с отнесением личности к референтным типам жизненных стратегий, сложившихся в данном социокультурном пространстве, а механизм индивидуализации придает стратегии жизни индивидуальный, неповторимый и уникальный облик, выражающий в целом своеобразие и качественную определенность личности. Доминирование механизма типизации над индивидуализацией может привести к формированию конформной модели жизненной стратегии, когда личность подчиняет свои интересы, жизненные цели и ценности общественным интересам и идеалам. Доминирование механизма индивидуализации над типизацией рождает конфликтную модель жизненной стратегии, когда поведение человека не согласуется с общественными нормами, ожиданиями и представлениями. Сотрудничество механизмов типизации и индивидуализации приводит к появлению консенсусной модели жизненной стратегии, которая включает в себя сочетание индивидуальных и социальных целей, задач, ценностей, принципов и так далее. Таким образом, процессы модернизации, происходящие в современном обществе, активизируют механизм индивидуализации жизненных моделей, которые зависят от личных усилий, квалификации и социальной компетенции.

В современной школе предполагается, что ученик должен внимательно наблюдать весь комплекс действий, понимать логику рассуждений учителя и схватывать учебный материал, переводя во внутренний план данные знания, делая их индивидуальными формами представления, мышления и памяти. 
Однако многие педагоги редко демонстрируют и очень слабо анализируют с детьми ход собственно учебной деятельности, а в отдельных областях знания это касается даже формирования предметных умений и навыков. Особенно там, где деятельность в большей степени реализуется во внутреннем плане действия и ее структуру трудно выделить.

Подобная ситуация складывается по многим предметам, в том числе и тех, где процесс деятельности строится на системе внешних действий. Например, на уроках изобразительного искусства часто можно столкнуться со следующей ситуацией: детям в начальной школе дают задание нарисовать осенний лист, не обучая тому, как это исполнять, какие действия и в какой последовательности осуществлять. Педагог обходится лишь общими словесными инструкциями в надежде на то, что они будут правильно восприняты, поняты и реализованы в практике.

Даже если опытный педагог отдельно показывает образцы деятельности, большинство приемов его работы остаются внешне заданными по отношению к внутренней структуре опыта ученика. Изучая правило, решая задачу, доказывая теорему, учитель в лучшем случае поступает следующим образом: показывает на собственном примере ход действий, комментируя отдельные этапы, которые, с его точки зрения, являются сложными для усвоения, забывая о том, что процесс познания и возникающие в его ходе трудности индивидуальны.

В разрабатываемой нами концепции «Целенаправленное развитие познавательных стратегий школьников» (ЦРПС) мы исходим из того, что личностно ориентированное обучение возможно лишь в том случае, если ученик осознанно и самостоятельно управляет учебной деятельностью.

Ведь чаще всего ребенок не успешен в обучении по следующим причинам: не понимает цели своей деятельности, не знает критериев достижения конечного результата, не представляет конкретных действий, которые следует осуществить (особенно это касается мыслительных операций); не имеет в предыдущем опыте сформированных в нужной степени действий и операций, не представляет хода своей деятельности как целостной структуры, не организует действия и операции в оптимальной последовательности, не проверяет свои действия в соответствии с критериями резуль1тата, не получает качественной и конструктивной обратной связи о своей учебной деятельности; не знает, что структуру собственного самоанализа возможно и полезно преобразовывать (развитие метарефлексии).
Чтобы изменить сложившуюся ситуацию, необходимо развивать покомпонентный анализ учебной деятельности, обеспечивающий рассмотрение того, как именно реализуются изначально целостные структуры деятельности (включающие наиболее важные взаимосвязи), которые обеспечивают эффективность реализации учения.

Средством формирования познавательной самостоятельности является целенаправленное развитие познавательных стратегий школьников.

Развитие познавательных стратегий нацелено на формирование познавательного опыта школьников, который позволяет ученику самостоятельно решать не только учебные задачи, но и любые жизненные проблемы. Накопление познавательного опыта происходит в процессе овладения основными компонентами содержания образования: педагогически адаптированных систем знаний, навыков и умений, опыта творческой деятельности и опыта эмоционально-волевого отношения, усвоение которой призвано обеспечить формирование всесторонне развитой личности, подготовленной к воспроизведению (сохранению) и развитию материальной и духовной культуры общества.

Средством формирования познавательного опыта является познавательная стратегия, которая с одной стороны позволяет выявить индивидуальный познавательный маршрут ученика, а с другой обеспечить интеллектуальное развитие.

Воспитание активной жизненной позиции школьников, овладение ими способами конструирования собственной жизни, на наш взгляд, обязательная составляющая воспитательной системы современной школы, так как в настоящее время общество более всего характеризуется двумя признаками - неопределенность и изменчивость, и социализация наших выпускников проходит в принципиально иных условиях, чем социализация их родителей, да и сами родители не очень ясно представляют, какие именно цели будет ставить жизнь перед их детьми в будущем.

Среди факторов, оказывающих влияние на проектирование жизненных стратегий школьника, самым важным и влиятельным была и остается семья, влияние которой ребенок испытывает рано, когда он к этому наиболее восприимчив. Семейные условия в значительной мере предопределяют жизненный путь ребенка. Родительская поддержка автономности, эмоциональная вовлеченность и структурированность требований к ребенку ведут к преобладанию у него внутренних стремлений и, как правило, к психическому здоровью.

Литература:

1. Гузеев, В.В. Познавательная самостоятельность учащихся и развитие образовательной технологии. М.: НИИ школьных технологий, 2004. 24 с.

2. Денисова, О.П. Психология и педагогика: Учебное пособие / О.П. Денисова. - М.: Флинта, МПСУ, 2008. - 240 c.

3. альчук, В. И. Особенности познавательной деятельности младшего школьника / В. И. Қальчук // Воспитание гражданина, человека культуры и нравственности - основа социальной технологии развития современной России: материалы Международного педагогического форума. - Ростов-на-Дону, 2010 - c. 410-414.. 
4. Қальчук, В.И. Проблема активизации познавательной деятельности в педагогической науке / В. И. Кальчук // Интеллект. Культура. Образование: материалы III Всероссийской научной конференции. - Новосибирск, 2010. - c. 100-101.

5. Никитина, Н.Н., Қислинская Н. В. Введение в педагогическую деятельность: теория и практика. - М.: Академия, 2008-224 с.

6. Новиков, А. М. Основания педагогики / Пособие для авторов учебников и преподавателей. - М.: Издательство «Эгвес», 2010. - 208 с.

\title{
Интеграционные подходы в обучении чтению и письму на уроках английского языка
}

\author{
Алиева Айше Эдемовна, преподаватель \\ Гулистанский государственный университет (Узбекистан)
}

$K^{\mathrm{a}}$ ак известно, чтение на английском языке - это один из видом речевой деятельности. Чтение - это значит читать вслух или про себя (беззвучно, глазами ) буквы, сочетания букв, слова, предложения, понимать содержание прочитанного, получать различные сведения из прочитанного. Чтение - вид речевой деятельности, при котором берутся сведения из письменной речи, то есть из письменного текста. Чтение — это получение новых сведений из прочитанного текста с незнакомым содержимым, понимание его содержания. Кроме всего этого, чтение - вид коммуникативной деятельности. Посредством чтения студенты знакомятся с языком, культурой, историей, традициями, жизнью англоязычных стран. Следовательно, чтение является источником получения новых сведений, новых знаний.

Обычно обучение чтению на английском языке состоит из обучения технике чтения и обучения пониманию содержания прочитанного. Если учащийся или студент понимает текст, у него формируются навыки чтения. Если обучающийся овладел техникой чтения, но не понимает прочитанное, то процесс чтения будет неполным.

На уроках английского языка применяются такие формы чтения, как: а) чтение вслух или громким голосом — reading aloud; б) чтение про себя или беззвучно (глазами) — silent reading; в ) индивидуальное чтение individual reading; г) чтение хором — reading in chorus. Все эти формы применяются исходя из задачи и цели обучения. Чтение вслух широко применяется при обучении технике чтения, а чтение про себя - при обучении понимания содержания. Индивидуальное чтение применяется при обучении выразительному чтению (вслух), при домашнем чтении на понимание содержания (про себя). Чтение хором применяется и при обучении технике чтения, и при обучении выразительному чтению.

Для того, чтобы учитель или преподаватель мог правильно организовать обучение чтению, он должен уделить особое внимание подбору текстов вне урока и организации работы с этими текстами на уроках.
У. Хашимов и И. Якубов предлагают делить работу над текстом с незнакомым содержимым на 4 этапа: 1 ) подготовительный этап; 2) этап непосредственного чтения текста; 3) этап после прочтения текста; 4) творческий этап. На первом этапе знакомятся с новым лексическим и грамматическим материалом. Если в тексте не встречаются новые слова или грамматические правила, то повторяется пройденный материал. На втором этапе учащиеся (студенты) читают текст вслух, или про себя. На третьем этапе проверяется понимание прочитанного посредством выполнения заданий. На четвертом этапе проводится обсуждение текста, его анализ [1]. Однако, в настоящее время большинство методистов склонны делить работу над текстом на три этапа: предтекстовой, текстовой и послетекстовый этапы $[2,3]$. При этом при обучении чтению студентов целесообразно предлагать им для чтения аутентичные тексты. К предтекстовому этапу можно отнести следующие задания: прочитать опорные слова и словосочетания и назвать тему текста; ознакомиться с новыми словами и предположить, о чем идет речь в тексте; догадаться по схеме из ключевых слов о содержании текста и озаглавить его; определить тему текста по иллюстрации; прочитать заголовок и сказать, о чем может идти речь в тексте.

На текстовом этапе важно правильно сформулировать задание к тексту: прочитать первый абзац рассказа и сообщить, о чем идет речь ( тема); прочитать первый абзац рассказа и найти в нем предложение, содержащее основную ин формацию; прочитать рассказ до конца и найти в последнем абзаце предложение, содержащее аргументацию главной мысли (идея); указать предложения, наиболее соотносящиеся по смыслу с заглавием; прочитать абзац и сформули ровать основную мысль одним предложением и др.

Послетекстовый этап работы нацелен на то, чтобы учащийся выразил свое отношение к прочитанному. Целью данного этапа является формирование у учащихся навыков и умений смысловой переработки текста. Для дальнейшего закрепления материала и мотивации творческой работы учащихся применяются продуктивно-творческие упраж- 
нения, а также всевозможные ролевые ситуативные игры. Учащиеся могут: выразить главную мысль текста, объяснить его заглавие; описать обстановку, в которой жили персонажи; рассказать о чувствах и мыслях героя в определенный момент; придумать диалог между героями; сказать, совпадает ли его точка зрения с авторской; выделить интересную информацию из рассказа и оценить ее и др.

При обучении чтению на уроках английского языка особое место уделяется разнообразным заданиям, которые можно классифицировать нижеслудющим образом:

Asking / Answering Question (вопросно - ответные упражнения) предполагают запрашивание и предоставление необходимой информации.

Categorizing - деление на категории - группировка языковых или смысловых элементов согласно обозначенным категориям или определение этих категорий.

Close - восстановление / заполнение пропусков приём работы со связным текстом, в котором преднамеренно пропущено каждое $\mathrm{n}$ - е слово (п колеблется от 5 до 10). Задача учащихся - восстановить деформированный текст, подобрать пропущенные слова по смыслу, исходя из контекста или привычной сочетаемости слов.

Completing - упражнение на дополнение - приём работы, основанный на отрывке текста или ряде незаконченных предложений, которые необходимо закончить, используя информацию, полученную из прочитанного текста.

Correction - исправление - определение и корректировка языковых или содержательных нарушений в тексте.

Gap - filling - заполнение пробелов/ пропусков приём работы, в основе которого лежит методика дополнения или восстановления недостающих языковых элементов.

Information Transfer - перекодирование информации - приём работы, заключающийся в переносе информации из одной формы её представления в другую, например, трансформация невербальную (картинка, жест, пр) или наоборот.

Jig — saw reading (listening) — «мозаика» — приём работы, основанный на разделении «банка информации», т.е. текста для чтения или аудирования. После ознакомления с определённой частью информации учащиеся обмениваются ею и восстанавливают общее содержание текста.

Matching - coотнесение / сопоставление - приём работы, заключающийся в распознавании соотносящихся друг с другом вербальных и невербальных элементов, например, между картиной и предложением, словом и его определением, началом и концом предложения и т.д.

Mind - mapping - составление семантической карты - представление основных понятий обсуждаемой темы / проблемы в графически упорядоченном и логически связанном виде.

Multiple choice - множественный выбор - выбор правильного ответа из предложенных вариантов.

Reordering (Sequencing) - логическая перегруппировка / восстановление последовательности - перераспределение предлагаемого материала в логической последовательности или согласно плану. Результатом работы является воссозданный связный текст, серия картинок и т.д.

Translation - перевод - выражение идеи на другом языке. При этом учащиеся должны принимать во внимание лингвистические и культурные особенности языка, на который делается перевод. Перевод может быть устным и письменным. [4]

Эффективность обучения чтению зависит от процессов чтения на родном и английском языках. Обучение чтению осуществляется на основе результатов методических экспериментов, опираясь на данные таких наук, как психология, психолингвистика, физиология. Это значит, что преподаватель должен быть знаком с данными этих наук, и, учитывая возраст обучаемых, исходить из индивидуальных свойств обучающихся.

Обучение чтению на английском языке требует, в свою очередь, от учащихся и студентов понимания вида речевой деятельности как способа получения сведений. Обучающиеся не должны воспринимать чтение и пересказ материала вслуз, сохранение его в памяти и перевод в качестве упражнения. Для того, чтобы чтение как вид речевой деятельности могло выполнить свою задачу, необходимо разивать у учащихся и студентов необходимые навыки и умения, присущие книгочитателю. Поэтому при обучении чтению и при формировании у обучащихся навыков чтения необходимо следовать нижеследующим правилам:

1. Нужно так выбирать тексты для чтения, чтобы учащийся, студент мог использовать содержащиеся в нем материалы в других видах деятельности, например, на других уроках, во внеклассной и самостоятельной работе и др.

2. Нужно создать возможности для большого выбора текстов для чтения, например, давать задания прочитать дома статьи из газет и журналов.

3. Нужно задавать задания, похожие на задания при чтении на родном языке, например, определить идею текста, оценить некоторые факты из текста и др.

4. При чтении текста поменьше пользоваться родным языком и переводом. Нужно научиться читать и понимать текст без перевода.

5. Нужно научить обучающихся читать вслух и про себя. Чтение вслух развивает навыки выразительного чтения, а чтение про себя развивает понимание содержания без перевода.

Литература:

1. Hoshimov O’., Yoqubov I. Ingliz tili o’qitish metodikasi. - Toshkent: Sharq, 2003. Стр.139-169. 
2. Маслыко, Е.А. Бабинская П.К. Настольная книга преподавателя иностранного языка. - Минск: Высшая школа, 2001.

3. Соловьевич, Н. А. «Обучение чтению аутентичных текстов лингвострановедческого содержания», ИЯШ, 1999, № 1.

4. Шапкина, С.А. Обучение чтению по английскому языку на старшей ступени образования.// URL: http:// festival.1 september.ru/articles/641275/

\title{
Формирование профессиональной мобильности будущих инженеров в вузе в процессе профессиональной подготовки
}

\author{
Баликаева Марина Бембаевна, кандидат педагогических наук, доцент; \\ Лапицкая Светлана Ивановна, старший преподаватель \\ Тюменский государственный архитектурно-строительный университет
}

$\prod$ реобразования в России в последнее время требуют мобилизации, прежде всего научно-технических ресурсов, интеллектуального потенциала инженерно-технической интеллигенции. Большая роль в этом процессе принадлежит постановке инженерного образования (engineering education - в пер. с англ. - техническое образование). Основную роль в подъеме экономики играет развитие промышленности, которое невозможно без хорошо организованной системы подготовки инженеров специалистов технического профиля (специалистов, получивших техническое образование).

Современный инженер - это специалист, обладающий высокой культурой, хорошо знающий современную технику и технологию, экономику и организацию производства, умеющий пользоваться инженерными методами при решении инженерных задач и в то же время обладающий способностью изобретательства [1]. Функции современной инженерной деятельности широки и разнообразны и это позволяет определить сущность ее как составную часть совместных творческих усилий рабочих, инженеров и ученых по преобразованию производительных сил общества. На основе анализа справочно-энциклопедической литературы мы можем сделать вывод, что инженерная деятельность - «это самостоятельный специфический вид технической деятельности всех научных и практических работников, занятых в сфере материального производства, который выделился на определенном этапе развития общества из технической деятельности и стал основным источником технического прогресса. Инженерная деятельность превратилась в наиболее массовый вид высококвалифицированного умственного труда [2; $3 ; 4]$.

Обратимся непосредственно к требованиям, предъявляемым работодателем к деятельности инженера. Характеристика деятельности современного инженера позволила нам выделить следующие ее составляющие: профессионально-инженерная деятельность (производственно-технологическая деятельность); организационно-проектировочная деятельность (проектирование, планирование и прогнозирование деятельности, направ- ленной на эффективное и продуктивное функционирование предприятия, постановка целей, решение задач по организации деятельности предприятия и его сотрудников); коммуникативно-управленческая деятельность (проведение деловых переговоров, совещаний, форумов, заключение договоров, управление деятельность коллектива); нормативно-правовая деятельность (осуществление деятельности в соответствии с законодательными актами, постановлениями, распоряжениями, составление приказов, нормативных актов); научно-исследовательская деятельность (изучение специальной литературы, касающейся выполняемой работы, а также по тематике проводимых исследований и разработок, составление различных производственных обоснований, справок, периодической отчетности, аннотаций, анализ проводимых исследований и достижений в производственной области с целью повышения своей профессиональной квалификации и продуктивности предприятия).

Работа по профессиональной подготовке будущего инженера - это сложный и трудоемкий процесс. В современном обществе именно высшее профессиональное образование призвано обеспечить будущему инженеру возможность успешной деятельности в сфере производства и науки. Мы согласны с мнением В.М. Вотинцевой [5], С. Е. Қаплиной [6], Л. П. Меркуловой [7] и других [8; 9], о том, что подготовку будущего инженера к профессиональной деятельности целесообразно начинать на ранних этапах обучения в вузе на междисциплинарном уровне. Совершенно очевидно, что деятельность современного инженера требует не только хороших знаний в области экономики; но также и в других областях - делового общения и профессиональной этики, математики, географии, юриспруденции, иностранных языков, компьютерных и интернет технологий. В этой связи, важно отметить роль требований нового федерального государственного образовательного стандарта высшего профессионального образования (ФГОС ВПО), основными положениями которого является междисциплинарность, практическая направленность и обра- 
щение к компетенциям [10]. Согласно ФГОС ВПО по направлению подготовки 270800.62 «Сроительство» по профилю «Промышленное и гражданское строительство» (квалификация (степень «бакалавр»), выпускник должен обладать общекультурными (OK) и профессиональными компетенциями (ПК). Среди общекультурных компетенций, значимых для нашего исследования, выделяются: «владение культурой мышления, способность к обобщению, анализу, восприятию информации, постановке цели и выбору путей ее достижения (OK-1); способность анализировать социально-значимые проблемы и процессы, происходящие в обществе, и прогнозировать возможное их развитие в будущем (OK-4); способность логически верно, аргументировано и ясно строить устную и письменную речь (ОK-6); готовность к кооперации с коллегами, работе в коллективе (OK-7); способность находить организационно-управленческие решения и готовность нести за них ответственность (OK-8); способность к саморазвитию, повышению своей квалификации и мастерства (ОК-9); осознание социальную значимость своей будущей профессии, высокая мотивация к выполнению профессиональной деятельности (ОK-11); владение основными методами, способами и средствами получения хранения, переработки информации, навыками работы с компьютером как средством управления: информацией, способностью работать с информацией: в глобальных компьютерных сетях (OK-13); владение одним из иностранных языков на уровне не ниже разговорного (OK-14). Деятельность будущего инженера характеризуется формированием в структуре его личности профессиональных компетенций (ПК), к которым относятся: общепрофессиональные и в соответствии с видами деятельности: производственно-технологическая, изыскательская, проектно-конструкторская, производственно-управленческая и коммуникативная, экспериментально-исследовательская, научно-исследовательская. Очевидно, что специфика профессиональной деятельности современного инженера обуславливает необходимость формирования как общекультурных, так и профессиональных компетенций в структуре его личности. Компетенции или профессионально-личностные качества будущего инженера взаимосвязаны и образуют целостную систему.

Исследование вопросов профессиональной подготовки будущих инженеров в вузе позволило установить, что понятие профессиональной мобильности тесно связано с самообразованием (Баликаева М.Б.) [11], (Вотинцева В.М.) [5], Меркулова Л.П. [7], конкурентоспособностью (Каплина С.Е.) [6], профессиональной компетентностью (Н. С. Сахарова) [12], и компетенциями (В. И. Байденко ) [13].

Руководствуясь положениями современного профессионального образования и требованиями работодателей, мы выявили профессионально-значимые характеристики личности инженера, позволившие конкретизировать педагогическую сущность исследуемого понятия. Так, в структуре личности инженера выделяются профессионально-личностные качества, профессионально-значимые знания и опыт профессиональной деятельности (Л. В. Горюнова) [14].

K профессионально-личностным качествам будущего инженера, сопряженным с мобильностью, относятся: мотивация, способность к адаптации, предприимчивость, активность. Профессионально-значимые знания представлены усвоением способов использования современных технологий и иноязычных средств общения в профессиональной деятельности. Опыт профессиональной деятельности представлен навыками прогнозирования, самоуправления и самооценки. Соответственно, ПМ будущего инженера рассматривается как интегративное качество личности, характеризующееся информационной оперативностью в условиях глобализации экономики, быстрой адаптацией к изменениям в профессиональной инженерной и научно-технической деятельности, проявляющейся в готовности к самостоятельному принятию эффективных решений в ситуации выбора, прогнозированию их последствий, инициативностью в использовании языковых средств, способствующих успешной профессиональной коммуникации.

Таким образом, анализ содержания профессиональной деятельности инженера позволил нам выявить производственно-технологическую, изыскательскую, проектно-конструкторскую, производственно-управленческая и коммуникативная, экспериментально-исследовательскую, научно-исследовательскую стороны ее структуры. Они, в свою очередь, находят непосредственное отражение в содержании профессиональной подготовки инженера, требования к которой зафиксированы современным ФГОС ВПО по направлению подготовки 270800.62 «Сроительство» по профилю «Промышленное и гражданское строительство» (квалификация (степень «бакалавр»). Основываясь на общие и профессиональные компетенции, формирование которых составляет цель профессиональной подготовки будущего инженера в вузе, мы пришли к заключению о том, что профессиональной мобильность является неотьемлемой частью его личности и системообразующим фактором формирования общекультурных, а в большей мере, профессиональных компетенций.

\section{Литература:}

1. Кононенко, Б.И. Большой толковый словарь по культурологии, 2003 г. [Электронный pecypc] http://dic. academic.ru (дата обращения: 17.01.2015).

2. Некрасов, Н.А. Философия науки и техники: тематический словарь. - Орёл: ОГУ. 2010. [Электронный ресурс] http://dic.academic.ru (дата обращения: 17.01.2015). 
3. Разин, В. М. Новая философская энциилопедия /Подредакцией В. С. Стёпина.: М.: Мысль.-2001. [Электронный ресурс] http://dic.academic.ru (дата обращения: 17.01.2015).

4. Ромашкин, К.И. Инженерная деятельность в социокультурном контексте: социально-философский анализ: дис... канд. филос. наук: 09.00.11 / К. И. Ромашкин. - Тула, 2004. - 131с.

5. Вотинцева, В.М. Интегрированное обучение иностранному языку как условие формирования профессиональной мобильности экономистов: автореф. дис... канд-та пед. наук: 13.00.08 / В. М. Вотинцева. - Чита, 2011. - 24c.

6. Қаплина, С.Е. Концептуальные и технологические основы формирования профессиональной мобильности будущих инженеров: автореф. дис... д-ра пед. наук: 13.00.08 / С. Е. Каплина. - Чебоксары, 2008. — 47 с.

7. Меркулова, Л.П. Формирование профессиональной мобильности специалистов технического профиля средствами иностранного языка: дис... д-ра пед. наук: 13.00.08 / Л. П. Меркулова. - Самара, 2008. - 455c.

8. Қазакова, О.П. Профессионально ориентированное обучение иностранным языкам // Известия Южного федерального университета. Педагогические науки. 2011. - № 6. - с. 137-142.

9. Дюпина, Ю. В., Шакирова Т. В. обоснование выбора принципов формирования лингвистической и коммуникативной компетенции студентов // Қачество. Инновации. Образование. 2014. - № 3. - С.34-38.

10. ГОС ВПО (Государственный образовательный стандарт высшего профессионального образования) // Российское образование: федерал. портал. URL: http://www.edu.ru (дата обращения: 14.10.2014.)

11. Баликаева, М.Б. Взаимосвязь иноязычного профессионального самообразования и формирования профессиональной мобильности в будущих инженеров в техническом вузе // Қачество. Инновации. Образование. 2014. № 8. C.24-29.

12. Сахарова, Н.С. Развитие иноязычной компетенции студентов университета: автореф. дис. д-ра. пед. наук / Н. С. Сахарова. - Оренбург, 2004. - 41 с.

13. Байденко, В.И. Болонский процесс Текст. / В. И. Байденко. - М.: Логос, 2004. - 208 с.

14. Горюнова, Л.В. Профессиональная мобильность специалиста как проблема развивающегося образования в России: автореф. дис. д-ра. пед. наук: 13.00 .08 / Л. В. Горюнова. — Ростов-на-Дону, 2006. — 45 с.

\section{Социально-педагогические основы привития национально-духовных ценностей в сознание студентов}

Болтаев Абдувохид Абдулазизович, преподаватель

Джизакский государственный педагогический институт (Узбекистан)

«Национальная программа подготовки кадров», учитывая ряд коренных изменений и реформ, проводимых в нашей стране, в настоящее время направлена на коренное преобразование форм, содержания, методов и системы подготовки национальных кадров.

Следовательно, система образования ставит на повестку дня усовершенствование системы подготовки кадров, обращая особое внимание на качество подготовки высококвалифицированных специалистов, отвечающих требованиям рыночной экономики, конкурентоспособных, творческих, с высокими интеллектуальными способностями педагогов. Именно сегодня процесс образования и воспитания, делающий особый акцент на усвоение студентами национально-духовных ценностей, является первостепенной задачей.

В связи с тем, что общество на различных этапах своего развития имеет серьезный подход к воспитанию молодого поколения, направляет внимание на обеспечение последовательности и непрерывности воспитания молодёжи, на происходящие в обществе события, наблюдаются поло- жительные изменения. Основная причина этого кроется в их социальной почве.

В древности, до того как появилась «Авеста», вступление наших предков в активные общественные отношения, процесс рационального осознания ими происходящего, можно зафиксировать и научно обосновать благодаря работам археологов, анализу древних писем, каменных памятников, произведений устного народного творчества.

Считается целесообразным эффективное использование священной книги зороастризма «Авеста» в привитии молодёжи национально-духовных ценностей. Поэтому слова Президента Республики Узбекистан И.А. Қаримова о национально-духовной ценности этого произведения имеют свою социальную основу: «Авеста» — наша самая священная древняя рукопись. Это книга - шедевр - духовное историческое наследие наших предков, которые жили между двух рек 30 веков назад».

Ценность рукописного сочинения наших предков в том, что эта книга наряду с религиозным, философским, поли- 
тическим и общественно-историческим значением, имеет и большое образовательно-воспитательное значение.

Р. Вохидов, Х. Эшонкулов высказывают о сущности и содержании «Авесты» следующую мысль: «Авеста, вместе с тем, что является священной книгой религии Заратустры, ещё и редкий энциклопедический источник, дающий сведения об истории, культуре, социально-экономической жизни, языке, обычаях, устном народном творчестве Турана и Ирана и других стран ближнего Востока».

Обучение и воспитание детей в «Авесте» осуществляются следующим образом: религиозное и нравственное воспитание, физическое воспитание, обучение чтению и письму.

В систему воспитания включены знания о законах, укладе зороастризма, общественной жизни, структуре общества, материальном мире, месте профессии в деятельности человека, положительных и отрицательных сторонах общества, мышлении человека, почтение к женщинам, семье, философических воззрениях о воспитании ребенка.

Путем ознакомления молодежи с этими сведениями, формируется чувство уважения к духовному наследию предков. В этом источнике особое внимание обращено на систему воспитания молодого человека как всесторонне развитой личности. Еще одной из социальных основ формирования национально-духовных ценностей являются орхоно-енисейские памятники. Материалы орхоно-енисейских надписей являются самыми ценными памятниками V-VIII веков.

Данные памятники представляют собой написанные на надгробных камнях эпитафии, описания событий, а также различные документы, печати, металлические деньги и др. Наряду с памятниками Кул-тегина и Бильге-Қагана, важными памятниками также являются стела Тоньюкука, Уюк-архун, Барлик, Тува и др. Они созданы народами, которые жили на обширных территориях Алтая и Монголии. В текстах идёт речь о киргизском, уйгурском и ряде других народов и племён, некоторые исторические личности отождествляются с той или иной этнической прослойкой.

Орхоно-енисейские памятники являются как памятниками языка и письма, так и историческими источниками. Эти памятники содержат ценный материал для изучения социально- экономической жизни V-VIII веков, знакомят с обычаями разных тюркских народов и племен, их убеждениями и т.п. Изучение молодёжью подобных национальных ценностей дает представление не только о языке, но и о духовной жизни минувших дней.

Посредством доведения до молодёжи представлений об образе жизни предков, общественных отношениях, системе родства, культурных связей с соседними народами, мыслей и размышлений о том или ином народе, племени, вожде, великих людях рода, развивается должное отношение к языку, обществу, родственникам, обычаям, традициям, отношения людей друг к другу.

Если расцвет науки и культуры Центральной Азии в IX-XII веках определяет эпоху раннего Возрождения в истории городов Центральной Азии, то в конце XIV -
XV веках культурный подъем произошел на основе формирования и развития независимого государства, освободившегося от монгольского ига.

Эту эпоху «можно назвать концом эпохи Возрождения - эпохой позднего Возрождения», - подчеркивает М. Хайруллаев в своей книге «Звёзда духовности».

Посредством обучения студентов культуре эпохи Возрождения, у них формируются и развиваются стремление к знаниям, сознательное отношение к обществу и природе, высокие нравственные качества, развивается чувство справедливости, дружбы и братства, налаживается воспитание развитого коллектива и человека. Позднее, под влиянием эпохи Возрождения, духовно-просветительская работа в Туркестане проходила в два этапа. На первом этапе, под влиянием новой европейской науки, такие просветители как Ахмад Даниш, Аваз Утар, Фуркат, Мукими пропагандировали изучение европейских языков. На втором этапе, на основе просветительства, появился джадидизм. В Туркестане открылись школы нового типа, прогрессивные педагоги-просветители создавали для этих школ учебники, книги для чтения, учебные руководства. В частности, в крае появились такие самоотверженные просветители, как Бехбуди, Мунаввар Кари, Фитрат, А. Авлони.

Их мысли по воспитанию, этике, нравственности были в основном сформированы на основе взглядов, существовавших в старину в исламском мире. Они внесли огромный вклад в систему воспитания, в частности, по привитию культуры общения. Вместе с тем, они обратили особое внимание на среду, эпоху, условия жизни общества. Педагогика этой эпохи, с учетом общественной жизни, её требований и нужд смогла продвинуться на шаг вперед по сравнению с предыдущим периодом развития педагогики Востока. Такие положительные проявления, имея особую роль в развитии общества, в системе образования и воспитания, приобретают важное значение в воспитании молодёжи на примере созидательных идей. Народ, воспитанный на примере духовных богатств предков, постоянно стремился к независимости, что дало свои результаты. Наш народ обрел свою независимость.

Независимость отрицает любое проявление колонизаторства, вытекающие из него препятствия и насилия. В то же самое время, независимость, наряду с разработкой специфических принципов развития, основанного на передовом мировом опыте, означает жизнь, основанную на новых, качественно высоких критериях, соответствующих общечеловеческим интересам.

Исходя из этого, прививая в сознание молодёжи идеи независимости, педагогика независимости приобретает важное значение в осуществлении системы воспитания развитого человека.

Педагогика независимости - это современная педагогика, рожденная в результате обретения Узбекистаном независимости и в связи с созданием условий для свободного мышления. В результате использования методов педагогики независимости создается возможность приве- 
дения образования и воспитания в соответствие со здоровым умом, творческой средой, национальным духом и традициями, обрядами и обычаями. Для педагогики независимости главной ценностью является не комплекс определенных знаний, а личность ребёнка.

Поэтому требования, поставленные сегодняшней молодёжи - это не только иметь больше знаний, но и быть искателем нового, инициатором, самоотверженным, интеллектуально способным».

Вследствие вышесказанного, можно сделать такое заключение, что мыслители, живя на этой земле, внесшие весомый вклад в мировое развитие, несомненно, великие гении, признанные в мировой науке.

Ученые и их ученики, обогащающие, дополняющие, совершенствующие работы великих мыслителей, и этим вносящие вклад в мировой прогресс, являются преемниками великих предков.

Значит сейчас, когда наша история своей неповторимостью освещает звезду благополучия нашего сегодняшнего дня, несомненно, можно констатировать, что наш завтрашний день, формирование сознания студентов является одной из актуальных задач педагогики.

Литература:

1. Каримов, И. А. Юксак маънавият енгилмас куч. - Т.: «Маънавият». -2008.

2. Йўлдошев, Ж., Хасанов С. Авестода ахлоқий-таълимий қарашлар. - Т.: «Ўқитувчи». - 1992.

3. Хомиджон Хомидий. Авестодан Шохномага. - Т.: «Шарқ». - 2007.

4. Хошимов, К., Сафо Очил. Ўзбек педагогикаси антологияси. — Т.: «Ўқитувчи». - 1995.

\title{
Дидактические игры на современном уроке химии
}

\author{
Веселова Лариса Александровна, преподаватель \\ Севастопольское президентское кадетское училище
}

Человек играет только тогда, когда он в полном значении слова человек, и он бывает вполне человеком лишь тогда, когда он играет.

Ф. Шиллер

$K^{a}$ аждый урок - это атом человеческой энергии, шаг к созреванию интеллекта, кирпичик в основании прекрасного здания, имя которому Развитие и Знание, без чего невозможен мыслящий и деятельный человек, который когда-то был обычным жизнерадостным и веселым ребенком, проводящим большую часть времени за игрой. Поскольку именно в игре дети познают окружающую действительность, учатся коммуникативным навыкам. Значение игры в развитии и воспитании личности уникально, так как игра позволяет каждому ребенку ощутить себя субъектом, проявить и развить свою личность. А. М. Макаренко писал: «Одним из важнейших путей воспитания я считаю игру. В жизни детского коллектива серьезная ответственная и деловая игра должна занимать большое место. И вы, педагоги, обязаны уметь играть».

Обратимся к словарю: «дидактическая игра» - это такая коллективная, целенаправленная учебная деятельность, когда каждый участник и команда в целом объединены решением главной задачи и ориентируют свое поведение на выигрыш. Дидактическая игра - это активная и (или) интерактивная учебная деятельность по имитационному моделированию изучаемых систем, явлений, процессов. Дидактические игры характеризуются наличием структуры, задач и определенных заданных правил, ко- торые могут иметь обучающий, организационный и формирующий характер.

Применяя дидактические игры на уроках, учитель одновременно выступает и как руководитель, который направляет и обучает детей, и в то же время сам является активным участником процесса. При этом возникает ощущение добровольности, свободы выбора, соревнования, самоутверждение и самореализация, что само по себе мотивирует учащихся к процессу обучения.

Г. К. Селевко писал: «В структуру игры как деятельности личности входят следующие этапы: целеполагание; планирование; реализация цели; анализ результатов, в которых личность полностью реализует себя как субъект. В структуру игры как процесса входят: роли, взятые на себя играющими; игровые действия как средства реализации этих ролей; игровое употребление предметов, т.е. замещение реальных вещей игровыми, условными; реальные отношения между играющими; сюжет (содержание) - область действительности, условно воспроизводимая в игре».

В современной школе, делающей ставку на активизацию и интенсификацию учебного процесса, игровая деятельность используется в таких ситуациях: - в качестве самостоятельных технологий; — как элементы более об- 
ширной технологии; - в качестве технологий урока; как технология внеклассной работы (коллективные творческие дела).

Многолетний опыт преподавания химии подсказывает, что на начальном этапе обучения целесообразно использовать методы активного обучения: игры, занимательную дидактику, ролевые и сюжетные постановки. Это создает непринужденную обстановку на уроке и позволяет активизировать познавательный интерес учащихся, их познавательную деятельность. Часто бывает, что при изучении сложного или объемного материала внимание учащихся рассеивается, они никак не могут сосредоточиться на уроке. Именно в таких случаях необходимо привлечь их внимание каким-либо интересным рассказом или игрой. Занимательная игровая дидактика, исторические сведения, курьезные случаи из жизни ученых-химиков помогают учителю разнообразить и оживить изложение сухого материала, вызвать интерес к теме и предмету в целом, активизировать ассоциативную память учащихся в процессе обучения.

Применяя дидактические игры, учитель формирует такие универсальные учебные действия, как умения анализировать различные варианты, систематизировать и классифицировать изученный материал; сравнивать и обобщать факты; излагать и аргументировать свою точку зрения; коммуникативные умения, при этом внимательно выслушивая сторонников и оппонентов. В процессе игры происходит личностное самоопределение и ценностно-смысловая ориентация учащихся, а также нравственно-этическое оценивание и ориентация в социальных ролях и межличностных отношениях.

При изучении химии крайне важно овладение терминами, т.к. они в научной практике имеют то же значение, что и слова языка, с которым связана мыслительная деятельность человека. Для запоминания и правильного употребления химических терминов можно использовать разнообразные игровые формы: составление кроссвордов и их разгадывание, химические диктанты, игра в слова, распознавание синонимов. Приведу примеры некоторых игр.

Термины-синонимы. Многие вещества имеют как номенклатурные, так и тривиальные названия. Выполнение заданий, в которых надо найти соответствие разных названий веществ, способствует более быстрому их запоминанию. Проведение в дальнейшем химического диктанта позволяет достигать высоких результатов в приобретении терминологических знаний. Например, составьте пары соответствующих названий веществ:

1. Гидрокарбонат натрия. А. Угарный газ.

2. Оксид углерода (IV). Б. Поваренная соль.

3. Хлорид натрия. В. Мел, известняк.

4. Оксид углерода (II). Г. Сода пищевая.

Подобные задания можно оформить в виде так называемых карточек быстрого ответа - изготовить карточку, желательно ее заламинировать и прикрепить к ней с лицевой стороны плотную прозрачную пленку, по которой ученик фломастером проведет стрелки предполагаемых ответов. След от фломастера легко стирается, и карточка готова к дальнейшему использованию.

Карточки быстрого ответа, описанные выше, подойдут и для следующих дидактических игр:

Восстанови пропущенное. В клетках игрового поля записаны знаки химических элементов, некоторые из них отсутствуют. По заданным критериям определить отсутствующие элементы.

Продолжи ряд. Заданы несколько членов ряда. Нужно обнаружить закономерность чередования объектов и продолжить ряд.

Убери лишнее. В предложенных рядах присутствуют «лишние» формулы. Согласно задания вычеркнуть их.

«Заполни поле». Игровые карточки-задания представлены в виде таблиц, имеющих верхнее и нижнее поля, при этом верхнее поле заполнено может быть формулами (или реагентами реакций), а нижнее поле должен заполнить ученик соответствующими названиями (или продуктами реакций).

«Крестики-нолики . Также карточки-задания представлены в виде заполненных табличек (соли, кислоты, основания). Ученик должен вычеркнуть правильный ряд.

Соответствие движению. Эта игра используется, чтобы внести в процесс обучения оживление и разрядку, которая способствует непринужденному запоминанию формул, названий, терминов, также можно использовать в качестве физминутки. Преподаватель с учениками устанавливают определенные правила. Например, называя кислоту, ученики должны поднять правую руку, а основание - левую, соль - хлопнуть в ладоши, кислотный оксид - повернуть голову вправо, а основный оксид - влево и т.д. Игра проходит весело и оживленно, учащиеся быстро запоминают необходимые химические соединения, учатся воспринимать информацию на слух.

Кто больше вспомнит слов. Игра способствует активизации реминисценций, повторению и запоминанию химических терминов. Она ориентирована на быстроту реакции (время ограничено до 5-7 мин). Пример: выбирают короткое слово («азот»), каждую букву этого слова пишут в отдельный столбик таблицы, учащиеся вспоминают и записывают химические термины, начинающиеся на данные буквы. Выигрывает тот, кто напишет больше химических терминов.

Логические цепи, Учитель задает начало фразы: «Хлор - неметалл». Первый ученик повторяет ее и придумывает продолжение со словами «потому что»,

«, следовательно»,, «поэтому». Затем все сказанное повторяет и продолжает следующий ученик. Тот, кто не смог продолжить цепочку, выбывает из игры. Далее учитель предлагает новую фразу.

Парадокс. Игра учит детей на слух воспринимать названия веществ и быстро ориентироваться в возможности их взаимодействия. Учитель или играющие команды задают вопросы по определенной теме. Вопросы должны 
быть продуманы заранее, они могут быть каверзными, тавтологическими или просто шуточными. Например, что произойдет, если растворить хлорид натрия в соленой воде? (Ничего. Это одно и то же вещество).

«Толстые» и «тонкие» вопросы. Изначально учитель объясняет суть игры - учит, как составлять «тонкие» и «толстые» вопросы, опираясь на текст учебника (возможно, при объяснении нового материала) и объясняет, какие на них должны звучать ответы. «Толстый» вопрос подразумевает развернутый ответ, а «тонкий» - односложный. Также эту игру можно применять и на других этапах урока.

Концептуальная таблица. Особенна полезна, когда предполагается сравнение трех и более объектов или несколько вопросов. Например, при обобщении материала по классам углеводородов предлагается таблица:

\begin{tabular}{|l|l|l|l|}
\hline Объект сравнения & Оксиды & Кислоты & Основания \\
\hline & & & \\
\hline
\end{tabular}

Сводная таблица «Что? Где? Когда?» позволяет организовать изучение предпосылок возникновения ведущих теорий химии - периодического закона Д. И. Менделеева и теории строения химических соединений А. М. Бутлерова, пользуясь учебником или лекцией.

Также учащимся очень нравятся такие дидактические игры, как блеф-игра «Верите ли вы, что...», «Верю - не верю» («Да-нет»), «Сходства и отличия», кроссворды, загадки, ребусы, игра с кубиком «Грани», на каждой грани которого дано определенное задание.

В настоящее время одним из важных этапов современного урока выделяют этап рефлексии, который иллюстрирует обратную связь «Ученик - учитель». Здесь возможно использование таких игровых форм, как стихотворные - написание синквейна, диаманты, кластера, лимерика..; рисунок; составление рекламного объявления, текста телеграммы; вопросы для интервью.
Игра - это один из методов обучения, ее не следует как переоценивать, так и недооценивать. Она должна органически включаться в учебный процесс по предмету в тесной связи с другими видами учебной работы. Поэтому основная задача, стоящая перед преподавателем химии, заключается прежде всего в том, чтобы на качественно новом уровне проводить учебно-воспитательный процесс и совершенствовать формы организации УВП. Необходимо четко понимать, что ученик - не объект, а субъект обучения согласно ФГОС 2 -го поколения. Он должен быть активным соучастником учебного процесса. Ребенок может усвоить информацию только через собственную деятельность при высокой мотивации предметом.

Развитие игровых технологий является перспективным направлением в методике проведения уроков химии.

Литература:

1. Габрусевич, С.А., Зорин Г.А. От деловой игры к профессиональному творчеству. - Учебно-методическое пособие. - Минск: «Университетское», 1989 г.

2. Гин, А.А. Приемы педагогической техники: Свобода выбора. Открытость. Деятельность. Обратная связь. Идеальность. Пособие для учителя. 2-е издание, - Москва, Вита-Пресс, 2000 г.

3. Занько, С. Ф. и др. Игра и учение. - Москва, 2000 г.

4. Кларин, М.В. Педагогическая технология. - Москва, 1989 г.

5. Пидкасистый, П. И., Хайдаров Ж. С. Технология игры в обучении и развитии. — Москва: РПА, 1996 г.

6. Самоукина, Н. В. Организационно-обучающие игры в образовании. - Москва: Народное образование, 1996 г.

7. Селевко, Г.К. Современные образовательные технологии: Учебное пособие.- Москва: Народное образование, 1998 г.

8. Интернет-ресурсы: https//ru.wikipedia.ord/wiki. 


\title{
Особенности физического воспитания студентов, имеющих отклонения в здоровье. Проблемы мотивации физкультурной активности студентов в вузе
}

\author{
Власова Татьяна Станиславовна, старший преподаватель; \\ Сунгатуллин Рафаэль Иршатович, старший преподаватель; \\ Закирова Найля Минкаримовна, асистент \\ Казанский (Приволжский) федеральный университет
}

$\prod_{1}^{\circ}$ данным статистики 60\% детского населения к шести годам жизни страдает хроническими болезнями, а к восемнадцати годам эта цифра уже приближается к 100\% отметке. Поэтому с каждым годом всё большее число студентов направляется врачами для занятий физической культуры в специальные медицинские группы.

В каждом вузе студенты, имеющие отклонения в здоровье, занимаются физической культурой по определённой программе, где должны решаться задачи не только учебно-педагогического плана, но и физического оздоровления, т.е. в определённом смысле, эти занятия должны выполнять функцию восстановления организма и служить подготовительным этапом адаптации к двигательным режимам, диктуемым жизнью.

Нужно отметить, что для студентов специальной медицинской группы важно не только создать оптимальный двигательный режим за счёт использования разнообразных комплексов и оздоровительных методик, но и сформировать у них потребность в самостоятельных занятиях физическими упражнениями за счёт обоснования необходимости поиска и оптимального использования всего арсенала средств самооздоровления организма.

На наш взгляд, именно на занятиях физической культуры, которые должны проводиться в форме практико-методических, студенты должны получать исчерпывающую информацию о методах и средствах оздоровления, учиться вычленять из этого многообразия то, что будет оптимально соответствовать уровню его здоровья, реально оценивать свои возможности и возможности своего организма. Занимающиеся должны твёрдо усвоить, что нет абсолютно универсальных систем и методик оздоровления, - все они нуждаются в определённой корректировке и адаптации под каждого конкретного человека, т.к. нельзя бездумно экспериментировать над своим организмом, следуя новомодным «панацеям».

Поэтому перед каждой кафедрой физической культуры, в том числе и перед нашей стоит задача обеспечить студентов соответствующей методической литературой, адаптированной к специфике вуза, научить молодых людей ориентироваться в информационном потоке, адекватно оценивать состояние своего здоровья, потребности и резервы организма, формировать убеждения в том, что сохранение здоровья - не лёгкий труд, а в широком смысле — это каждодневная победа над самим собой.
Для студентов Вузов свойственна работа, связанная c напряжением внимания, зрения, интенсивной умственной деятельностью и малой подвижностью. А тем из них, кто имеет какие-либо ограничения в состоянии здоровья, в частности - студенты специальной медицинской группы, в большей степени подвержены последствиям интенсификации образовательного процесса.

Одна из важнейших задач процесса физического воспи тания в вузе - формирование сознательного отношения студентов к своему здоровью, развитие потребности в систематических занятиях физическими упражнениями, формирование уверенности в своих силах и возможность преодолевать значительные физические нагрузки, особенно в условиях повышенной нервно-эмоциональной и психической напряженности.

Слабая мотивация у студентов к занятиям физической культуры в вузе - одна из проблем физического воспитания в высшей школе. Как показали опросы, в подавляющем большинстве студенты положительно относятся к данному виду деятельности и не отрицают необходимости занятий физической культурой, но на этом фоне выявлен относительно низкий уровень мотивации непосредственно к занятиям физической культурой в рамках учебного процесса. Из мотивов, побуждающих к занятиям физической культурой студентами были выделены те, цель которых тесно связана с сущностью физической культуры: укрепление здоровья, коррекция телосложения, снятия нервного напряжения, активный отдых и другое. Никто из опрошенных, понимая позитивность влияния физической культуры на жизнь человека в целом, не отрицал необходимости таких занятий. Но, тем не менее, 30 \% студентов приводили те или иные мотивы «пассивности», «неучастия», большинство из которых носило характер «ситуационных»: не хватает времени, лень, не могу себя заставить, нет условий, далеко живу и другое.

Что касается занятий физической культуры непосредственно в вузе, то многие студенты (20\%) посещают занятия, чтобы получить зачет, и стараются не пропускать их $(60 \%)$ только из-за возможности административных санкций.

Такое отношение, на наш взгляд, складывается во многом из-за недопонимания студентами целей и задач физического воспитания в вузе. Учебное занятие - это не секция по спортивным интересам и не альтернатива фитнес-клубу, но в то же время особенности предмета 
позволяют, в определенной мере, учитывать интересы и склонности занимающихся при планировании учебных занятий, естественно, в соответствии с состоянием материально-спортивной базы учебных заведений.

Необходимо до сознания студента довести четко сформулированную мысль о том, что целью практических и практико-методических занятий по физической культуре в вузе является не только повышение уровня физической подготовленности и физического развития занимающихся, поскольку понятно, что за количество часов, отводимых на физическую культуру в рамках учебной программы, сложно достичь значительных изменений этих двух показателей. Задача преподавания гораздо шире. Важно дать студентам максимально полный объем информации о средствах и методах физической культуры, о том, как и для чего они используются, каких результатов позволяют достичь, как их можно корректировать и создавать алгоритмы для индивидуальных занятий, естественно все это закрепляя практическими навыками. Иными словами, необходимо удовлетворить потребность молодых людей в получении социально значимой информации, научить ею оперировать в соответствии с собственными интересами и склонностями в области физической культуры и спорта.

Таким образом, наряду с реализацией целого комплекса задач физического воспитания в вузе, мы должны делать определенный акцент и на обучающе-информационной стороне занятий. Такой подход, как показывает практика, с одной стороны, требует высокой квалификационной подготовки преподавателей, с другой, - дает реальную возможность поднять статус занятий физической культурой в вузе, что, в свою очередь, позволит выйти на позитивные изменения мотивации студентов к таким занятиям.

Исходя из нашего опыта работы на занятиях физической культуры со студентами, отнесённые к специальной медицинской группе, мы часто используем упражнения по системе Йозефа Пилатеса, которые состоят из плавных неспешных движений, чем-то напоминающих танцевальные па и направлены на растяжение, укрепление нервно-мышечной системы и достижение согласованной работы всех частей тела. Причём, задействованы не только крупные поверхностные мышцы, но и мелкие глубокие, до которых обычными силовыми упражнениями не «добраться». Именно внутренние мышечные слои являются опорой для позвоночника и суставов. От их состояния зависит гармоничное развитие тела и то, насколько стойким окажется результат. В отличие от других занятий в пилатесе такие показатели, как количество подходов и повторов, не столь важны. Делая любое движение, студент должен понимать, что происходит в этот момент в его организме. Данная программа подходит абсолютно любому студенту.

Прежде, чем приступить к занятиям, нужно изучить основные принципы системы Пилатес. Без этого невозможно добиться по-настоящему хороших результатов.

Ключевым моментом в занятиях по Пилатесу является дыхание, чем больше кислорода поступает в мышцы, тем лучше они работают. Поэтому студенту нужно следить за тем, чтобы его дыхание было максимально глубоким и постоянным. Нужно наполнить лёгкие до предела воздухом и также до конца их освободить. Результаты данных наблюдений свидетельствуют о заметном улучшении состояния дыхательной системы у студентов, что в свою очередь помогает им концентрироваться, контролировать свои движения, увеличивать силу и гибкость на занятиях физической культуры, а также повысить сопротивляемость организма к воздействию неблагоприятных факторов внешней среды. Все упражнения разработаны на научной основе и состоят из трех фаз: сначала мышцы растягиваются, затем укрепляются, наконец, снова растягиваются.

Также на занятиях со специальной медицинской группой мы включаем элементы китайской гимнастики Цигун - «энергетический поток». Комплекс состоит из пятнадцати упражнений и рассчитан на студентов не имеющих большой физической подготовленности. Редкие упражнения из комплекса, которые противопоказаны при некоторых диагнозах (прим.: «скручивание» при сколиозе, «сотрясение» тела при нефроптозе и т.п.), заменялись преподавателем на более подходящие. Элементы китайской оздоровительной гимнастики использовались в течение одного семестра $2-3$ раза в месяц на занятиях у студентов I-III курсов. В последствие было проведено анонимное анкетирование, в котором участвовало 52 студента, занимающихся на I-III курсах (38 девушек и 14 юношей). На вопрос: «Қак часто вы хотели-бы заниматься восточной оздоровительной гимнастикой на занятиях?» «Регулярно - ответили $72 \%$ девушек и $28 \%$ юношей. «Изредка» - ответ 18\% девушек и 26\% юношей. Не проявили интереса к упражнениям - 10\% девушек и $36 \%$ юношей. Наиболее удобным временем для занятий физической культурой, по мнению студентов, является 2 и 3 пары - 10 и 12 часов дня (60\%)

Среди причин, не позволяющих полностью заниматься физической культурой, были названы: «неудобное расписание» - 61\%, «нехватка времени из-за учёбы (работы)»-12\%, «лень»-13\% и «сон вместо физкультуры» выбрали $14 \%$ респондентов.

$43 \%$ анкетируемых отметили, что занятия элементами цигун - «это необычная форма проведения физической культуры», «могут быть полезны для здоровья» - считают $57 \%$ опрошенных (из них 54\% - девушки ). Ни один из студентов не выбрал ответ: «Подобные занятия мне не интересны». Таким образом, можно сделать вывод, что периодически включая в занятие малоинтенсивные, эмоциональные упражнения, такие, как «энергетический поток», мы оптимально подготовим студентов относящихся к специальной медицинской группе к последующим учебным занятиям Подобные упражнения помогут плавно подготовить к физической и умственной работе.

Мы считаем, что подобные занятия периодически могут использоваться как альтернатива традиционным формам физической культуры как в школах и вузах, так и на производстве. 
Функциональные нарушения осанки и сколиотическая болезнь достаточно распространены среди студентов относящиеся к специальной медицинской группе. В этом случае преподаватель и студенты вместе решают как минимум три задачи: мобилизация позвоночника, его коррекция и стабилизация достигнутой коррекции. Упражнения с фитнес мячом позволяют эмоционально и целенаправленно использовать его при формировании осанки и коррекции ее отклонения.

Как показала практика, физические упражнения на больших мячах заставляют студента постоянно корректировать свое тело для устойчивости в пространстве, совершенствовать чувство координации. Мягкость фитбола исключает резкие реакции опоры на позвоночник и его мышечно-связочный аппарат, создавая щадящие режимы его функционирования даже при прыжках на мячах. Занятия с фитболом определенно вносят эмоциональную окраску при выполнении физических упражнений. Сту- денты с огромным желанием занимаются физическими упражнениями на мячах.

Правильно подобранные упражнения и объяснения преподавателем техники выполнения способствуют развитию гибкости, силы, выносливости, укрепляют весь мышечный корсет как позвоночника, так и опорно-двигательного аппарата.

Таким образом, в ходе проведенного исследования подтверждается важность использования различных оздоравливающих методик как средство формирования активно-положительного отношения студентов к занятиям физической культуры. А совершенствованию профессионально-педагогической деятельности подлежат профессиональные знания, непрерывность пополнения которых будет способствовать преподавателю создавать и применять в практике работы со студентами новые технологии обучения, творчески подходить к собственному опыту, быть на уровне требований к педагогам современной высшей школы.

\title{
Способы повышения мотивации при изучении английского языка
}

\author{
Вовненко Светлана Ивановна, преподаватель
}

Севастопольское президентское кадетское училище

Исследование опыта профессиональной подготовки будущих военнослужащих в современных условиях реформирования вооруженных сил Российской Федерации предусматривает поиск путей повышения эффективности преподавания дисциплины английский язык, начиная с самой ранней ступени обучения - с кадетского училища. Анализ существующих научных работ по повышению эффективности обучения показал, что одним из ведущих факторов в изучении иностранного языка выступает мотивация. Таким образом, целью данной статьи является рассмотрение способов повышения мотиващии воспитанников Севастопольского президентского кадетского училища в ходе изучения дисциплины английский язык с целью улучшения качества преподавания предмета в данном учебном заведении.

Ключевые слова: мотивация, иноязычная коммуникация, образовательно-познавательная деятельность, коммуникативная компетенция, творческий подход, психология образования.

$\bigcup_{\text {о }}$ овременные исследования в области педагогики и психологии уделяют достаточно много внимания явлению мотивации. В настоящее время, факт того, что мотивация играет огромную роль при изучении любого предмета, особенно иностранных языков, является общепринятым. Однако, изучение проблемы повышения мотивации в ходе овладения английским языком в условиях среднего военного учебного заведения представляет собой малоисследованный аспект. Таким образом, целью данной статьи является определение путей повышения мотивации при изучении английского языка на примере воспитанников кадетского училища.

Широко известно, что английский является официальным языком международных учений и встреч на высшем уровне. Это язык политических переговоров и многих общественных организаций. Однако как предмет, конечная цель которого овладение навыками иноязычной коммуникации (как устной, так и пись- менной), он обладает рядом специфических черт, одна из которых - овладение английским языком путем обучения умению общения на иностранном языке. Следовательно, исходя из актуальных потребностей и специфики изучения предмета, важнейшим фактором в обучении речевому общению на английском языке служит мотивация усвоения иностранного языка. Рассматривая основополагающие понятия мотивации, мы, вслед за И.А. Зимней, будем опираться на тот факт, что «мотив - это то, что объясняет характер данного речевого действия, тогда как коммуникативное намерение выражает то, какую коммуникативную цель преследует говорящий, планируя ту или иную форму воздействия на слушающего» [5, с. 18].

Вне зависимости от уровня и типа учебного заведения, изучая иностранный язык, необходимо создавать такие условия в образовательно-познавательной деятельности, которые способствуют развитию у обучаемого высокого уровня познавательного интереса к изучению ан- 
глийского языка. Существует много различных мнений по определению видов мотивов, которые формируются у обучаемых при изучении английского языка. Так, например, В.Д. Шадриков в работах, посвященных психологии образования считает, что «мотивация обусловлена потребностями и целями личности, идеалами человека, условиями его деятельности (как объективными, внешними, так и субъективными, внутренними - знаниями, умениями, способностями, а также характером)» [7, с.44]. Р.А. Готлиб полагает, что «мотивация — это такая движущая сила, которая побуждает человека к успешному изучению иностранного языка» [1, с.82]. Следовательно, мотив рассматривается как внутреннее побуждение учащегося к учебной деятельности, вызванное личными потребностями самого обучаемого, в частности, индивидуальными особенностями развития его личности.

В педагогической литературе достаточно подробно описаны два вида мотивов: внутренние и внешние. Внутренние - которые развиваются под воздействием собственных мыслей обучаемого, его стремлений, переживаний, возникновения определенных потребностей, в результате чего появляется осознание внутренней необходимости.

Тем не менее, анализ опыта преподавания данной дисциплины в Севастопольском президентском кадетском училище показал, что не у всех кадетов на момент поступления в военное учебное заведение были сформированы только положительные мотивы к изучению английского языка, что обусловлено изучением другого иностранного языка в их первичном учебном заведении. Таким образом, первоочередной задачей педагога президентского корпуса является снижение уровня влияния отрицательной мотивации и стимулирование позитивных мотивов к изучению дисциплины.

Еще одним фактором негативного воздействия на развитие положительной динамики мотивации является и разный уровень владения кадетами английским языком на момент поступления в севастопольское кадетское училище. Т. е. исходя из существующих реалий формируются так называемые mixed-abilities groups (группы смешанного уровня знаний). В этом случае первоочередной задачей педагога является «выровнять» уровень знаний учащихся путем проведения дополнительных занятий с более слабыми учащимися, а также теми, кто ранее изучал другой иностранный язык; организации индивидуальной работы в группе; организации «кураторства» более сильных учеников над слабыми.

С самого начала изучения курса английского языка педагогу необходимо четко определить линию мотивации и область применения английского языка в будущей профессиональной деятельности обучаемых. В ходе анализа научной и методической литературы, а также материалов периодической печати были выявлены основные направления использования английского языка в современной военной среде.

Таким образом, процесс модернизации системы российского образования в условиях социально-экономиче- ских изменений в стране в начале XXI века на фоне экономической, социальной и культурной глобализации в мире и наличия единого мирового информационного пространства в обществе актуализирует проблему повышения качества языкового образования в целом.

В современных условиях реформирования Вооруженных Сил Российской Федерации происходят значительные преобразования и структурно-функциональные изменения, что в значительной мере влечет за собой изменение концепции военного образования, в связи с чем предъявляются новые требования «к профессионализму, техническому кругозору и компетентности военных самого современного уровня» [4].

Сегодня в качестве одного из приоритетных направлений военного образования рассматривается формирование будущего офицера, обладающего высокими нравственными и профессиональными качествами, способного оперативно и квалифицированно действовать в военной обстановке, как в нашей стране, так и за ее пределами. В данной ситуации крайне необходимо быть толерантным к культуре и традициям других стран, что достигается путем тщательного изучения иностранного языка. Современный военный специалист должен иметь не только военно-специальные знания, но и понимать современную картину мира.

Важность английского языка для военных значительно выросла в последние десятилетия, этот рост во многом является результатом двух факторов: изменения роли военных и изменения в оборонном отношении.

Все вооруженные силы сегодня стали более активно привлекаться к обеспечению гуманитарной помощи и миротворческих операций, в том числе и международных. Необходимо как можно раньше начинать развивать лингвистическое мышление (навык мыслить на английском языке), рассуждать логически, уметь четко выразить свою мысль, используя все выразительные средства языка; использовать английского язык как средство получения и обмена информацией, пользования компьютером и сетью Интернет для получения знаний в разных областях науки и техники, пользования различными программами для выполнения расчетов. В Севастопольском президентском кадетском училище, созданы все необходимые условия для реализации вышеперечисленных задач, начиная с первого курса обучения в училище с 5 -го класса.

Исходя и специфики данного учебного заведения, необходимо не только обучить воспитанника английскому языку как инструменту общения, но и привить все те навыки, которые будут необходимы в будущей карьере военнослужащего. Для реализации этих задач необходимо выделить ряд основных факторов, способствующих формированию у воспитанника кадетского училища положительных мотивов к изучению английского языка, основными из которых, на наш взгляд являются: понимание целей обучения; профессионально-направленное содержание учебного материала; развитие познавательных 
способностей кадетов; заинтересованность предметом; эмоциональная форма ведения занятий преподавателем; постановка преподавателем сложных, развивающих умение самостоятельно мыслить и принимать решение заданий, способствующих развитию творческой активности учащихся; осознание важности получаемых знаний; оценка знаний; формирование прикладных целей изучения языка.

Некоторые исследователи считают, что внешние мотивы не связаны с содержанием учебного материала. К ним относятся: долг, обязанность (учащийся должен изучать данный предмет, чтобы получить положительную оценку); оценка (стремление набрать как можно больше баллов за четверть). Однако здесь следует учитывать не только отметку за знание того или иного учебного материала, но и мотивирующую роль самого воспитанника, которая очень велика. Познавательная мотивация наиболее важна в обучении иностранному языку. Однако необходимо, чтобы она стала основной для развития профессиональной направленности кадетов, стимулировала их учебную активность, хорошую успеваемость, положительное отношение к изучаемому языку. Отношение к английскому языку во многом зависит от оценки важности их профессиональной подготовки по специальности. Познавательный мотив в овладении английским языком объясняется правильной организацией учебной деятельности, учитывая профессиональную направленность кадетов, применяя разнообразные методы ведения занятий, а также объективной оценкой знаний обучаемых. Большую роль в повышении мотивации у кадетов особенно на начальном этапе обучения (5-й, 6-й классы) играют различные виды работы, применяемые преподавателем на уроке: уроки-обсуждения разных тем; уроки-общения с кадетами по Интернету (эффективен как вариант самостоятельной подготовки); круглые столы; мини-конференции в группах; уроки-тесты; уроки в режиме online; уроки-презентации, а также видеоуроки. Существенное значение в последнее время имеют уроки, направленные на обучение воспитанников кадетского училища делать презентации на английском языке как по общей, так и по военной тематике (учитывая возрастной критерий обучаемых).

Преподавателями кадетского училища при проведении урока английского языка широко используются элементы страноведения, что позволяет воспитанникам подробнее ознакомиться с культурой стран изучаемого языка, их традициями. Также на положительную мотивацию повлияло и использование не только учебной, адаптированной литературы, но и аутентичных материалов. Исходя из того, что конечной целью обучения является свободное владение коммуникативными навыками, использование аутентичных материалов демонстрирует яркий пример оригинальной речи, к чему и должен стремиться каждый изучающий иностранных язык.

Говоря о формах проведения занятия, особое внимание на уроке заслуживает такая форма, как ролевая игра. Этот вид учебной деятельности является групповым, что очень ценно в процессе формирования воинского коллектива. Ролевая игра основана на совместных действиях, коллективной форме выполнения задания. В данной работе ведущая роль отводится не педагогу, а кадетам. Т.о., еще в стенах среднего учебного заведения происходит развитие таких качеств личности будущего военного как воля, организованность, находчивость, инициативность. Ролевая игра предусматривает умение руководствоваться в своем поведении интересами товарищей, стимулирует интерес к импровизации, заставляет принимать самостоятельные решения. Все это также, безусловно, пробуждает интерес к предмету и стимулирует положительную мотивацию [7].

В качестве перспективного направления изучения английского языка педагоги кадетского училища рассматривают внедрение в учебный процесс компьютерных технологий, так как они способствуют более эффективному формированию иноязычной коммуникативной компетенции учащихся и играют немаловажную роль в развитии позитивной мотивации обучения: развивают необходимые коммуникативные умения в различных видах речевой деятельности, в занимательной форме презентуют социокультурную информацию о стране изучаемого языка, формируют основы самостоятельной учебной деятельности.

С психологической точки зрения компьютерное обучение иностранному языку значительно повышает уровень мотивационной готовности к изучению иностранного языка, создает психологически комфортную атмосферу на уроке, обеспечивает большую степень интерактивности в общении и адаптированности к нуждам конкретного ученика [6].

Таким образом, анализируя существующие на сегодняшний день возможности изучения английского языка, представляется возможным сделать вывод о том, что эффективность процесса обучения иностранному языку зависит не только от готовности преподавателя и обучаемых и от тех современных технологических решений, которые найдут применение на уроке, но и от умения педагога обосновать необходимость изучения предмета и осуществить творческий подход к преподаванию данной дисциплины.

Литература:

1. Готлиб, Р.А. Социальная востребованность знания иностранного языка. Социологические исследования, № 2, Февраль 2009, С. 122-127.

2. Дельвиг, Н.А. Теоретико-методологические основы формирования билингвальной компетенции будущих офицеров в условиях военно-морского ВУЗа Российской Федерации. Науч. обосн. темы докт. дисс. Ялта, 2014.

3. Зимняя, И.А. Педагогическая психология. - Ростов-на-Дону: Феникс, 1997. — 480с. 
4. Качественно иная страна. Российская газета. - 2008. - 9 февраля. - № 4585.

5. Семёнова, Т.В., Семёнова М.В. Ролевые игры в обучении иностранным языкам.// Иностранные языки в школе. - 2005. - № 1 .

6. Солопова, Е. В. Формирование иноязычной коммуникативной компетенции младших школьников с применением компьютера в процессе обучения. Автореферат на соискание ученой степени кандидата педагогических наук. Елец, 2008. - 20 с.

7. Шадриков, В.Д. Психологическая деятельность и способности человека. - М.: Издательская корпорация «логос», 1996. - 320 с.

8. Щукина, Г.И. Активация познавательной деятельности учащихся в учебном процессе Текст. / Г. И. Щукина. M.: Просвещение, 2011.- 134 с.

9. Ellis, R. The Study of Second Language Acquisition Text. / R. Ellis. - Oxford, 2010. — 204 p.

10. Palmer, H. The Scientific Study and Teaching of Language Text. / H. Palmer. London, 2012. - 137 p.

11. Обучение иностранным языкам. Материалы для специалиста образовательного учреждения. М., 2003.192 c. http://study-english.info/article018.php\#ixzz3R7pNcmVW

\title{
Формирование географических представлений на уроках географии в условиях современной школы
}

\author{
Гайсумова Лиза Джунидовна, кандидат экономических наук, доцент; \\ Эльмурзаев Руслан Супьянович, старший преподаватель; \\ Иразова Малика Александровна, документовед \\ Чеченский государственный университет (г. Грозный)
}

$\mathrm{O}$ дним из наиболее необходимых предметов в школе является география, которая способствует формированию целостного представления об окружающей среде. Преподавание географии, содержание которой отражает основы географической науки, отличается от других предметов комплексным подходом изучения природы, общества и предмета их взаимодействия, обладает значительным потенциалом для достижения целей экологического обучения и воспитания учащихся на всех уровнях школьного обучения. География, будучи междисциплинарным и интегрированным предметом, изучает, как окружающую среду и социум, так и демографию, этнографию, географию транспорта, туризма, религий, культуры и многие другие направления. Устойчивое развитие территорий, страны и мира, глобальные проблемы человечества рассматриваются в географии и значительная роль должна отводиться методике ее преподавания, как предмета формирующего у учащихся целостное представление о мире и процессах в нем происходящих [4].

Обучение географии в школе имеет важное образовательное и воспитательное значение. Это знания о Земле, ее внутреннем строении, о рельефе, климате, водах, почвах, растительности, животных, населении, природных ресурсах, мировом хозяйстве, о природе и хозяйстве стран, о Мировом океане и отдельных океанах, о своей стране и т.д.. Благодаря этим знаниям можно объяснить с научной точки зрения многие природные и общественные явления, ориентироваться в окружающем мире, они содействуют развитию широкого кругозора. Преподавание географии дает не только географические знания, но и знания по другим отраслям наук, основы которых не изучаются в школе, обеспечивает экономическую подготовку учащихся, школьники получают целостное представление о хозяйстве, его отраслях, формах организации, природных ресурсах, мировом хозяйстве. Природные ресурсы и условия в школьной географии рассматриваются с точки зрения возможности их использования в хозяйстве [1].

Формирование представлений на уроках географии это формирование зрительного образа ранее воспринятого объекта или явления (представление памяти, воспоминание), а также образ, созданный воображением. В процессе учебной деятельности формируется два вида представлений: представление памяти и представление воображения.

Представление памяти - это зрительный образ, который формируются в результате непосредственного наблюдения объекта или явления или восприятия его с помощью различных средств наглядности. В настоящее время процесс формирования зрительных образов особенно эффективен в результате применения электронных дидактических средств обучения, когда на экране принтера или на интерактивной доске возникает или моделируется образ географического объекта или явления [2].

Представление воображения - это образы географических объектов или явлений созданные продуктивным воображением без непосредственного их наблюдения и восприятия. Представления в таком случае формируются в процессе яркого образного рассказа учителя, чтения учащимися дополнительного текста о географических открытиях, путешествиях, исследованиях. 
В процессе преподавания географии формируются обобщенные и единичные представления, пространственные и картографические представления, представления графической интерпретации представления о приборах, с помощью которых осуществляются наблюдения, предусмотренные учебной программой.

Обобщенные представления - это представления учащихся о географических объектах, не имеющих собственных названий. Формирование таких представлений осуществляется одновременно с формированием общих понятий. Единичные представления - это представления о конкретных географических объектах имеющих собственные географические названия. Их формирование осуществляется одновременно с формированием единичных понятий [3].

Картографические представления формируются о пространственном расположении на земной поверхности материков и океанов, форм рельефа, отдельных крупных географических объектов, их величине, простирании, особенностей береговой линии и др.

Графическая интерпретация (истолкование, объяснение) позволяет формировать образные представления о системе понятий раскрывающих базовое понятие. Например, схема внутреннего строения вулкана формирует представление учащихся о магматическом очаге вулкана, его боковых кратерах, о жерле вулкана, лавовых потоках и других продуктах извержения, формируя тем самым полное образное представление учащихся о базовом понятии «вулкан».

Источниками формирования представлений являются:

- окружающая учащихся географическая действительность;

- наглядные средства обучения: картины, таблицы, графическая наглядность, дополнительный текст и иллюстративный материал учебника, модели географических объектов и явлений;

- электронные средства обучения: компьютерные программы, презентации к урокам, учебные компакт-диски, веб-сайты и веб-страницы с материалами по темам школьных курсов географии;

- географические карты, в том числе и контурные карты;

— яркий образный рассказ учителя;

— познавательные телевизионные программы;

- хрестоматии по географии с описанием изучаемых территорий.

Основными условиями и особенностями формирования географических представлений являются: Формирование представлений осуществляется в результате наблюдений географических объектов или явлений в природе или их рассмотрении и восприятии с помощью средств наглядности: картин, таблиц, графической наглядности, коллекций минералов, горных пород, полезных ископаемых, рисунка учителя на классной или интерактивной доске, при демонстрации динамических моделей. Формирование представлений осуществляется одновременно с формированием понятий. Это единый процесс познания географических объектов и явлений. Так, формируя базовое понятие «горные страны», учитель с помощью наглядных средств обучения одновременно формирует образные представления о понятиях раскрывающих сущность базового: горный хребет, перевал, вершина горы, горная долина, горное ущелье, нагорье и др. Наиболее оптимальным приемом одновременного формирования системы понятий и образных представлений является использование электронных средств наглядности. Учитель сам может разработать такие электронные образовательные слайды по наиболее значимым темам курса и, при проведении урока по соответствующей теме, осуществлять формирование понятий и образных представлений демонстрируя образы этих понятий моделируя географические процессы с помощью компьютера и интерактивной доски; Формирование представлений — это активный управляемый учителем процесс. При демонстрации слайдов учитель акцентирует внимание учащихся на отличительных признаках изучаемых объектов, явлений, формулирует вопросы как репродуктивного, так и проблемного характера, организует составление учащимися схем, таблиц, описание продемонстрированных объектов по предложенному плану. В результате выполнение заданий по нанесению объектов на контурную карту у учащихся формируется образное представление о величине объекта, его простирании, пространственном расположении на земной поверхности и расположения относительно других объектов; Формирование представлений возможно при условии обучения учащихся умению наблюдать объекты и явления в природной среде, рассматривать их, работая с различными наглядными средствами обучения, в том числе и с электронными.

Представление - это зрительный образ ранее воспринятого географического объекта или явления. В результате непосредственного наблюдения географических объектов или явлений формируются представления памяти. Представления воображения формируются продуктивным воображением без непосредственного наблюдения изучаемых объектов или явлений. При изучении географии у школьников формируются обобщенные, единичные, пространственные, картографические представления и представления в результате графической интерпретации содержания школьных курсов географии в виде схем, таблиц, графиков, диаграмм, профилей и др.

Успех в формировании у школьников представлений во многом определяется преемственностью, развитием умений от одного курса к другому. В целом же проблема формирования представлений относится к числу наиболее сложных и актуальных проблем современной методики обучения географии. Одна из причин сложности данной проблемы состоит в том, что формирование представлений во многих случаях объективно труднее для учащихся, чем усвоение знаний.

Значение преподавания географии велико, как единственного предмета, охватывающего широкий спектр взаимодействующих проблем и способствующего осознанию учащимися взаимосвязи естественных и общественных дисциплин, природы и общества. 
Литература:

1. Гакаев, Р.А., Чатаева М.Ж. Преподавание географии в школе и его значение как междисциплинарного учебного предмета. Научное обозрение. 2014. № 4.

2. Галай, И. П. Методика обучения географии, Минск.2006.

3. Иванов, Ю.А. Методика преподавания географии. Брест. 2012.

4. Рашидов, М.У., Гакаев Р.А. К вопросу взаимоотношения общества и природы в Чеченской Республике. Вопросы современной науки и практики. Университет им. В. И. Вернадского № 3 (9) /2007

\section{Технология чтения-рассматривания на уроках во 2 классе}

Григоровских Елена Сергеевна, учитель начальных классов мБоУ СоШ № 6 имени М. В. Ломоносова (г. Самара)

2015 год в России объявлен годом русской литературы с целью сохранить и приумножить культурную целостность нашей страны, при этом сохраняя свою самобытность, национальные ценности и духовные традиции. Умение работать с книгой - одно из универсальных учебных действий. Это умение формируется на основе книговедческих и литературоведческих представлений и понятий. Освоение этих умений можно представить в виде совместной деятельности читателя и книги. В дошкольном детстве ре- бёнок знакомится с произведениями художественной литературы, осваивает нравственные ценности, заключённые в этих произведениях путём чтения - слушания и игры. Младший школьник в основном имеет дело с учебной литературой, используя также художественные книги и дополнительную литературу.

В таблице представлены объекты читательской деятельности и способы чтения в разном возрасте, на разных этапах обучения:

\begin{tabular}{|l|l|l|}
\hline \multicolumn{1}{|c|}{ Возраст } & \multicolumn{1}{|c|}{ Объекты читательской деятельности } & \multicolumn{1}{c|}{ Способы чтения } \\
\hline Дошкольники & Художественная литература & $\begin{array}{l}\text { чтение - слушание } \\
\text { чтение - игра }\end{array}$ \\
\hline 1 класс & Букварь + азбуки & чтение - рассматривание \\
\hline 2 класс & $\begin{array}{l}\text { Учебники «Русский язык», «Литературное } \\
\text { чтение», «Математика»+ справочная литера- } \\
\text { тура }\end{array}$ & $\begin{array}{l}\text { чтение - рассматривание + } \\
\text { просмотровое чтение }\end{array}$ \\
\hline 3 класс & $\begin{array}{l}\text { Учебники «Окружающий мир», «Технология»+ } \\
\text { справочная, познавательная литература }\end{array}$ & выборочное чтение \\
\hline 4 класс & $\begin{array}{l}\text { Учебники «Физическая культура», «Музыка», } \\
\text { «Изобразительное искусство»+ справочная, по- } \\
\text { знавательная литература }\end{array}$ & поисковое чтение \\
\hline
\end{tabular}

В 1 классе первой и главной задачей является вызвать у первоклассника интерес к детской книге, сформировать умение работать с ней. Добиться этого можно используя на уроках следующие приёмы работы с книгой:

1. Работать с выставкой книг на всех без исключения уроках.

2. В период обучения грамоте широко использовать книги-азбуки, созданные детскими поэтами: «Мохнатую азбуку» Б. Заходера, «Цирковую азбуку» В. Берестова, «Научусь-ка я читать» Е. Благининой;

«Азбуки в стихах и картинках» С. Я. Маршака и другие.

Қаждый урок литературного чтения - это особая встреча с автором произведения. Эта встреча должна быть интересной, неожиданной, полезной. Поэтому нужно её организовать так, чтобы дети стали собеседниками, открывателями. Для этого нужно начать разговор с автором книги.

Во 2 классе используем технологию просмотрового и изучающего чтения учебных книг по алгоритму:

1) Назначение - книга, которая учит.

2) Авторы: обложка, титульный лист, выходные данные.

3) Форзацы.

4) Аннотация

5) Условные обозначения

Предлагаю фрагмент урока по русскому языку во 2 классе по теме «Основа слова» (С.В. Иванов Русский язык: 2 класс, урок 72) 


\begin{tabular}{|c|c|c|}
\hline Этапы урока & Деятельность учителя & Деятельность учащихся \\
\hline $\begin{array}{l}\text { Чтение - рассма- } \\
\text { тривание материалов } \\
\text { урока }\end{array}$ & $\begin{array}{l}\text { - Покажите, где начинается и заканчи- } \\
\text { вается урок } 72 . \\
\text { - Каковы задачи этого блока? } \\
\text { Где это можно посмотреть? } \\
\\
\text { - Прочитайте тему урока. } \\
\text { - Что интересного заметили? Каким } \\
\text { цветом выделена тема? } \\
\text { Что это значит, где посмотреть? } \\
\text { - Просмотрите урок от начала до } \\
\text { конца. } \\
\text { Сколько разных видов работ нам пред- } \\
\text { стоит? Как это узнать? } \\
\text { - Что обозначает каждый значок? Где } \\
\text { это узнать? } \\
\text { - Сколько упражнений в этом уроке? }\end{array}$ & $\begin{array}{l}\text { Рассматривают, находят и показывают } \\
\text { в учебнике начало и конец урока. } \\
\text { - Начинается урок с названия блока } \\
\text { «Как устроен наш язык». } \\
\text { - Отыскивают страницу } 3 \text { в учебнике, } \\
\text { просматривают и находят описание содер- } \\
\text { жания этого блока (Открывать законы, по } \\
\text { которым живёт язык) } \\
\text { Читают название темы «0снова слова» } \\
\text { Находят на стр.3 нужный значок и читают } \\
\text { текст справа от него. } \\
\text { Просматривают урок, находят условные } \\
\text { обозначения - названия рубрик. } \\
\text { На стр.3 находят каждый значок и читают } \\
\text { текст справа от него. } \\
\text { Просматривают урок, показывают - } 5 \\
\text { упражнений. }\end{array}$ \\
\hline $\begin{array}{l}\text { Работа с материалами } \\
\text { урока }\end{array}$ & $\begin{array}{l}\text { Как называется наша страна? } \\
\text { А как сказать по-другому? } \\
\text { - Что значит отечество? От какого } \\
\text { слова происходит? } \\
\text { — Что можете сказать про эти слова? } \\
\text { - Корень «отец-отеч» помогает понять } \\
\text { значение слова. } \\
\text { Предлагается слайд. } \\
\text { Родина - это место, где человек ро- } \\
\text { дился и рос. Это его город, дом, двор, } \\
\text { улица или переулок... } \\
\text { - Есть ли здесь родственные слова? } \\
\text { - Помогает этот корень понять зна- } \\
\text { чение слов? } \\
\text { - Рассмотрите схемы (даны на слайде } \\
\text { схемы к этим словам) } \\
\text { — Что надо дабавить к корню, чтобы } \\
\text { значения слов стали понятны? } \\
\text { Вывод: не всегда значение слова можно } \\
\text { объяснить с помощью корня. Для этого } \\
\text { существует основа слова. } \\
\text { Прочитайте определение в учебнике. }\end{array}$ & $\begin{array}{l}\text { Россия. } \\
\text { Родина, отечество. } \\
\text { Отечество - отец } \\
\text { Они родственные, имеют общий корень, } \\
\text { и схожи по значению. Значение - отец. } \\
\text { Чтение со слайда. } \\
\text { Улица, переулок общий корень - ул- } \\
\text { Нет } \\
\text { Просматривают страницу, находят читают } \\
\text { определение понятия «основа слова» } \\
\text { В слове «улица» добавить - суффикс } \\
\text { и окончание, в слове «переулок» - при- } \\
\text { ставку и суффикс. } \\
\end{array}$ \\
\hline
\end{tabular}

Литературные произведение оказывают огромное влияние на формирование личности ребёнка. Рассматривание книг и их чтение, чтение-рассматривание - это тут путь, которым через изучение книг-объектов во всём их многообразии учитель ведёт учеников от незнания к знанию, к самостоятельности. 


\title{
Литература:
}

1. Федеральный государственный образовательный стандарт начально общего образования, 2009.

2. С. В. Иванов, А. О. Евдокимова, М.И Кузнецова. Русский язык: 2 класс: учебник для учащихся общеобразовательных учреждений: в 2ч. - 4-е изд., перераб. - М.: Вентана-Граф, 2012.

3. Николаева, Е. И., Петрова Е.Н. Основы духовно - нравственной культуры народов России. Я в мире людей: Учебник для 4 класса: В 2 ч. - Самара: Изд. «Учебная литература»: Издательский дом «Фёдоров», 2013.

4. Светловская, Н. Н. Методика внеклассного чтения: Кн.для учителя. - 2 -е изд., перераб. - М.: Просвещение, 1991.

\section{Creating a textbook in ESP on the basis of a professional discipline}

\author{
Демидова Ольга Михайловна, старший преподаватель \\ Томский политехнический университет
}

At the present time teaching ESP requires new teaching aids. The article represents creation of the textbook in ESP on the basis of the authentic professional discipline. The contents, the hierarchical organization of the textbook, principles of material's selection, and creation of $L 2$ activities are described.

Keywords: teaching aid, communicative competence, English for Specific Purposes, "sheltered instruction".

$\mathrm{R}^{\mathrm{s}}$ ussia's integration into the educational and scientific community resulted in adopting new educational standards of higher education, led to the necessity «to form skills and abilities of professional communication of specialists» [15, p.100]. According to the Federal Educational Standards of Education of the Third Generation the level of competence in a foreign language of graduates should be not lower than the level of general communication. But, it should be admitted, that «the required level is extremely high and hardly achievable with hours given and low knowledge of language» [7, p.29].

Increasing demands to the linguistic competence of future engineers made it necessary to develop the system of teaching English for specific purposes (ESP) on a new basis. One of the possibilities is to develop communicative competence combining studying the ESP and a professional discipline on the basis of authentic materials. The concept «authentic» is defined as «truly, genius» [25, p.414], «original» $[12$, c.53]. In the article as «authentic materials» we understand not-adapted texts of the textbook in English and describe the process of creating a textbook in ESP on the basis of the textbook by R.S. Hibbeler «Engineering Mechanics. Statics» [23].

\section{Review of existing courses}

Our work started with investigation of existing works of national and foreign colleagues on the given issue. We have studied the works of F. Grellet, S. Hood, N. Solomon, A. Burns, S. J. Savignon, S. Thornburry devoted to the issues of teaching reading and communication in English [22-27]. The works of many foreign researchers deal only with theoretical sides of the given issue. For example Zoltán Dörnyei, suggests «only a short review of the key issues of communication ...» in his work [21, c. 34]. The work of J. R. Anderson describes neurological, psychological issues of acquisition, reading and teaching mathematics [16]. The works of R. M. De Keyser, Z. Dörnyei and E. Ushioda deal with the question of motivation and acquisition [17-20]. Some aspects of teaching communication are given in the works of O. A. Baeva, I. Yu. Varlamova, O. Ya. Goihman, F. A. Kuzin, B. N. Lavrinenko, A. P. Panfilova [2-13]. But, they deal with the business communication, not communication in engineering. Such situations as « calculating the water pressure on the dam; calculating the hydrostatic pressure on the cylindrical vessel » [4, p. 176], discussion of these problems and their solution are typical for engineers. These problems reflect our life, but on the other side, require abilities to communicate in these situations both in a native language and in a foreign language. This communication has its peculiarities and requires a new approach in teaching ESP.

A lot of textbooks are already used in teaching ESP to future engineers. N. Yu. Gusevskaya divides the «existing textbooks into two groups» [7, p.29]. The drawbacks of the first group she names that «their first issues were done in 70-80-th years of the XX century; all the following issues were reprinted without great changes in methodological and linguistic content» $[7$, p.29]. The drawbacks of the second group are absence of system, long approbation, and irrelative level of the tasks to the level of competence of learners, too many mistakes and misprints [7, p.30]. The textbooks by I. P. Agabekyan and P. I. Kovalenko are widely used in the process of teaching ESP to engineers [1]. The texts in this book are excellently selected and cover such aspects of engineering as ferrous and non-ferrous metals, plastics, types of leathers, but they lack L2 tasks which de- 
velop strategies of reading and understanding unknown texts in a foreign language, communicative tasks and tasks in writing. The textbook by T. Yu. Polyakova "English for Engineers" is aimed at the development of professional texts, but mostly, the exercises deal with grammar aspects of English [14]. Accourding to the classification of N. Yu. Gusevskaya they belong to the first group of the textbooks. Also, we studied the textbooks by A.S. Belyaeva [3], A.A. Demina, A. N. Oleynik [8]. The drawbacks of these textbooks are enumerated in the second group of N. Yu. Gusevskaya classification [7, p.30].

During the study of the literature we enriched our pedagogical, methodical knowledge, enforced our author's position. We consider important to study ESP on the basis of the authentic materials of a professional discipline, for example, engineering mechanics, as engineers of all specialties use the knowledge of this course in their professional activity. This course contains engineering problems, axioms, mathematic symbols, formulas and equations. This peculiarity influences the communication in the given sphere. The future engineers learn to prove their point of view, using the knowledge of applied sciences, such as mathematics, geometry, physics, and strength of materials. Our final aim was to de- velop communicative competence in a professional sphere. The communicative competence in a foreign language includes several competences: linguistic, sociolinguistic, strategic, discursive, and social. [8, p.102].

As a communicative competence in a professional sphere we understand ability to organize their utterances accurately, logically, coherently both in written and oral forms in order to optimize different aspects of professional activity. Professional communication may be introduced in several forms: monologue (report, presentation), dialogue, polylogue.

Here we can include business dialogues, interviews, discussions, negotiations. The gradation of the forms of communication depends on the number of people who take part in communication.

\section{Thematic and Hierarchical organization of the Textbook}

The textbook 'Engineering Mechanics (English for Specific Purposes)' was published in 2006. In 2010 it was recommended by the Ministry of Education and Science of Russian Federation in Foreign Languages. Table 1 shows the contents of the textbook 'Engineering Mechanics (English for Specific Purposes)'.

Table 1

\begin{tabular}{|l|}
\hline Chapter 1. Basic concepts and principles \\
\hline The subject of Statics \\
Force \\
Fundamental Principles \\
\hline Chapter 2. Composition of Forces. Force couples in a plane. \\
\hline 2.1 Geometrical Method of Composition of Forces \\
2.2 Resolution of Forces \\
2.3 Equilibrium of a System of Concurrent Forces \\
\hline 3. Parallel Forces and Force Couples in a plane \\
\hline 3.1 Composition and Resolution of Parallel Forces \\
3.2 Moment of a Force about a point \\
3.3 A Force Couple. Moment of a Couple \\
3.4 Vector Expression of the Moment of a Couple \\
3.5 Moment of a Force with Respect to an Axis \\
\hline
\end{tabular}

A paragraph includes texts on the given professional topic. They are accompanied by the list of specialized and scientific vocabulary which is drilled in the given unit. After the texts the system of exercises is given. The exercises start with those of a controlled practice stage; go to the exercises developing strategies of reading and understanding professional texts to the open-ended practice stage exercises, and exercises on communication. We also include Appendixes. Appendix 1 gives the information how to read mathematical symbols, signs, fractions. Appendix 2 contains illustrations of

Table 2

\begin{tabular}{|l|l|l|l|}
\hline \multicolumn{2}{|c|}{ Appendix 1 } & \multicolumn{2}{|c|}{ Appendix 2 } \\
\hline$\sqrt{4}= \pm 2$ & $\begin{array}{l}\text { the square root of 4 is (equals) } \\
\text { plus or minus 2 }\end{array}$ & $\begin{array}{l}\text { Determine the intensity } q, \text { if } \\
\begin{array}{l}M_{A}=546 \mathrm{Nm}, F=136 \mathrm{~N}, \\
M=42 \mathrm{Nm}, A B=C D=2 \mathrm{~m}, \\
B C=1 \mathrm{~m} .\end{array}\end{array}$ \\
\hline
\end{tabular}


engineering problems and tasks which need to be solved. Below, you can see some examples of information given in the appendixes 1 and 2 .

The system of exercises is logically constructed from the easiest to the most difficult ones. Below you can see the diagram illustrating the system of exercises given in the textbook - level one contains the easiest exercises, e.g. drilling vocabulary and prepositional phrases; level 2 contains two groups of exercises: the first group develops reading strategies on the level of words, sentences and text; the second group of exercises develops speaking skills (quasicommunicative skills); level 3 contains open-ended practice exercises and communicative exercises on writing, speaking and listening. These parts include the following exercises:

Table 3

\begin{tabular}{|c|c|c|c|}
\hline № level & Group of exercises: & \multicolumn{2}{|c|}{ Examples of exercises: } \\
\hline 1 & Controlled practice exercises & \multicolumn{2}{|c|}{$\begin{array}{l}\text { exercises on pronunciation, word formation and imitation, selection of } \\
\text { synonymous series }\end{array}$} \\
\hline \multirow[t]{4}{*}{2} & Reading strategies exercises & Level of words & $\begin{array}{l}\text { Exercises training: } \\
\text { knowledge of suffixes, prefixes and roots } \\
\text { to determine the meaning of unfamiliar } \\
\text { words; } \\
\text { use of the context to determine the } \\
\text { meaning of unfamiliar words } \\
\text { the use of international or related words }\end{array}$ \\
\hline & & Level of sentences & $\begin{array}{l}\text { Exercises which develop the following } \\
\text { abilities: } \\
\text { to notice the key words with the primary } \\
\text { semantic meaning in a sentence } \\
\text { to understand the logical connections in } \\
\text { simple and complex sentences } \\
\text { to use correctly the linking words }\end{array}$ \\
\hline & & Level of text & $\begin{array}{l}\text { Exercises which develop the following } \\
\text { abilities: } \\
\text { to recognize the key information in the } \\
\text { text } \\
\text { to predict the contents of the text } \\
\text { to test hypotheses while reading } \\
\text { the ability to understand contextual links }\end{array}$ \\
\hline & quasi-communicative exercises & \multicolumn{2}{|c|}{ selection of definitions, reading of formulas, explaining of illustrations } \\
\hline 3 & $\begin{array}{l}\text { Open-ended practice exercises, } \\
\text { communicative exercises }\end{array}$ & \multicolumn{2}{|c|}{$\begin{array}{l}\text { Exercises on professional and scientific writing and speaking: dialogues, } \\
\text { games, interviews and presentations, written descriptions and comments on } \\
\text { diagrams, charts, writing summaries and proofs etc. }\end{array}$} \\
\hline
\end{tabular}

\section{Principles and criteria for selecting ESP material}

While selecting the texts used in the process of studying ESP on the basis of this course, we followed these criteria: authenticity, professional importance, richness in information. Building the list of vocabulary we stuck to the following principles:

1. topic selection. We selected the terms, specialized words and expressions, which are important for the communication in this course.

2. semantic selection. All of the selected lexical items express the most important concepts in this course and comply with the studied subjects.
3. principle of matching. The chosen words and expressions have a high mutual combinability, which means, they are all communicatively important in the field of professional communication on the topics being studied.

4. principle of word-building importance - all selected lexical units have a high ability to form new words with the help of affixes.

\section{Examples of the L2 activities and exercises}

The system of L2 tasks in the textbook "Engineering Mechanics (English for Specific Purposes)" follows the principle of increasing of language complexity - from 
drilling up to the level of communicative tasks. These L2 tasks may be modified according to the needs of the learning. Giving the examples of exercises, we will follow Table 3, which illustrates the hierarchical organization of the system of exercises.

\section{Level 1. Controlled practice exercises.}

It contains exercises on vocabulary drilling, on pronunciation, word formation and imitation, selection of synonymous series. We introduce exercises not in the complete form for the sake of space, just illustrations for our colleagues to understand the general idea of exercises. In round brackets we give the number of the page in the text book, where this exercise goes.

Exercise 7. You have two columns of the words taken from the text. Match the words having the similar meaning. (p.16)

\section{1. equilibrium} 2. load

After the perfection of lexical and grammatical skills through the exercises mentioned above, we offer a system of exercises aimed at development of reading skills and language strategies. It is important to point out that the goal of reading is to satisfy the needs in information which is necessary and important for communication. This requires a high level of reading comprehension. To teach learners to understand specialized texts, we must teach reading strategies and strategies of understanding a text in a foreign language [20, p.98]. The system of exercises presented in the textbook is aimed at the development of reading strategies at three levels, at the level of: words, sentences, text.

Level 2 Reading strategies exercises Level of words.

1) These are exercises which train knowledge about the composition of words: knowledge of suffixes prefixes and roots to determine the meaning of unfamiliar words.

2) Exercises that teach to use the context to determine the meaning of unfamiliar words

3) Exercises that train the knowledge of international or related words. For example:

Level 2 Reading strategies exercises Level of Sentences

Here we use exercises which develop following abilities:

1) The ability to notice the key words with the primary semantic meaning in a sentence.

2) The ability to understand the logical connections in simple and complex sentences:

1) to understand the relationship between the subject and the predicate of the sentence.

2 ) to use correctly the linking words (knowledge and correct use of subordinating, coordinating conjunctions, adverbs, the knowledge of linking words). For example:

Level 2 Reading strategies exercises Level of Text

Here we use exercises which develop following abilities:

A) to recognize the key information in the text

B) to predict the contents of the text

\section{c. balance}

b. weight

C) to test hypotheses while reading

D) to understand contextual links, i.e. connections between words and elements which were mentioned earlier in the text, for example, the use of personal, possessive, demonstrative pronouns in connection with the nouns. After perfection of knowledge of lexis and grammar it is necessary to go to the productive level of exercises. But, as our teaching experience showed it is efficient to go through the level of quasi-communicative exercises.

Level 2 Quasi-communicative exercises

These are exercises on selection of definitions, reading of formulas, explaining of illustrations.

Level 3 Open-ended practice exercises, communicative exercises

Here, we introduce exercises on professional and scientific writing and speaking: dialogues, games, interviews and presentations, written descriptions and comments on diagrams, charts, writing summaries and proofs etc.

\section{Conclusion}

Developing a communicative competence in ESP is a complicated process. Teachers working in this sphere should pay attention to different aspects of this process. In this article we shared the experience of creating a textbook and developing a communicative competence of future engineers in a foreign language on the basis of the authentic materials of a professional discipline, in our case, engineering mechanics. We described the structure, organization of the textbook and the system of exercises that was created with the aim to teach future engineers communication in their professional sphere. These exercises may be used and adapted by the teachers of English according to the teaching needs. We hope our experience will be useful for our colleagues in different educational establishments.

\section{References:}

1. Агабекян И.П., Коваленко П.И. Английский для технических ВУЗов. Серия «Высшее образование».- Ростов н/Д: «Феникс», 2004. - 352 с

2. Баева О.А. Основы риторики и бизнес коммуникации. - М.: ЮНИТИ-ДАНА, 2005-328 с.

3. Беляева А.С. Учитесь читать литературу по специальности на английском языке. - М.: Высшая Школа, 1987. - 135 c. 
4. Березовская О. М., Болсуновская Л. М., Замятин В. M. Engineering Mechanics(English for Specific purposes) Томск: Изд.Томского Политехнического Университета, 2011. - 188 с.

5. Варламова И. Ю., Будильцева М. Б. Деловой этикет. Деловая коммуникация, РУДН, Москва, 2011

6. Варламова И. Ю. Основы деловой и языковой коммуникации. Тесты, практические упражнения и упражнения для самостоятельной работы студентов инженерных специальностей, РУДН, Москва, 2013, - 78 с.

7. Гусевская Н.Ю., Проблема и опыт создания учебного пособия по английскому языку // Гуманитарный вектор. - 2011. - 1 (25). - с. 29-32.

8. Девина Л.И. Реализация компетентностного подхода в учебном пособии по английскому языку для студентов-юристов // Вестник МГЛУ. - 2012. - 12 (645). — c.101-109

9. Демина А. А., Олейник А. Н., Английский язык. Пособие для аспирантов. - Томск, изд. ТПУ, 2000. - 144 с.

10. Кузин Ф.А. Культура бизнес - коммуникации, ЮНИТИ-ДАНА, Москва, 2007, - 320 р.

11. Лавриенко Б. Н. Психология и этика бизнес коммуникации, ЮНИТИ-ДАНА, Москва, $2004,-415$ с.

12. Мюллер В. К. Англо-русский словарь. - М.: Русский язык, 1992. - 2106 с.

13. Панфилова А. П. Бизнес коммуникация в профессиональных сферах, Знание, Санкт-Петербург, 2004, - 495 с.

14. Полякова Т. Ю. Английский язык для инженеров. Высшая школа, Москва, 1998, - 436 с. // Вестник МГЛУ .2012. - $12(645) .-$ c. $101-109$

15. Полякова Е.И. Социокультурная, коммуникативная и профессиональная составляющие языковой подготовки будущих специалистов // Альманах современной науки и образования. - 2015. - 2 (92). - c.100-102

16. Anderson J. R. Learning and memory: An integrated approach. - NJ.: John Wiley \& Sons, 2000. - 279 p.

17. De Keyser R.M. Practice in second language: Perspectives from applied linguistics and cognitive psychology.New York: Cambridge University Press, 2007. - 304 p.

18. Dörnyei Z. Motivational strategies in the language classroom. - Cambridge: Cambridge University Press, 2001. - 164 p.

19. Dörnyei Z. The psychology of second language acquisition. - Oxford: Oxford University Press, 2009. - 339 p.

20. Dörnyei Z. \& Ushioda E. Teaching and researching motivation. - Harlow: Longman, 2010. - 304 p.

21. Dörnyei, Z, Communicative Language Teaching in the 21 st Century: the "Principled Communicative Approach"// Perspectives. - 2009. - V. 36 (2) - P. 33-43.

22. Grellet F. Developing Reading Skills. A practical Guide to reading Comprehension Exercises - CUP, 1981. — $252 \mathrm{p}$.

23. Hibbeler R. C. Engineering mechanics. Statics. - Prentice Hall, Inc., 1995. - 574 c.

24. Hood S., Solomon N., Burns A., Focus on reading. - CUP: National Centre for English Language Teaching and Research, 2002.- $134 \mathrm{p}$.

25. Hornby A. S., Gatenby E. V., Wakefield H. The advanced learner's dictionary of current English. - Сигма — Пресc, 1996. - $2000 \mathrm{c}$.

26. Savignon S. J., Communicative competence: theory and classroom practice - CUP: Addison - Wesley Publishing Company, 1983. - $322 \mathrm{p}$.

27. Thornburry S. How to Teach Grammar. - CUP: Pearson Education Limited, 1999. - 182 p.

\section{Поликультурное пространство как основа построения содержания образования в начальной школе}

Длужневская Дарья Александровна, магистрант

Омский государственный университет

$\prod^{\prime}$ роисходящие сегодня коренные изменения во всех областях жизни общества меняют парадигму образования, которая формулируется по принципу: «Образование - это часть культуры». Образование является важнейшей функцией культуры, так как именно оно обеспечивает ее сохранность, трансляцию и потенциальное развитие. В соответствии с новой парадигмой образования в основу концепции российского образования положен принцип овладения учащимися знаниями, умениями и навыками в контексте единой общечеловеческой куль- туры. И поскольку сегодня каждый человек органически вписан в сеть массовых коммуникаций, он становится носителем не только набора элементов национальных и региональных субкультур, но и общечеловеческой культуры.

Взаимодействие культур порождает общение, диалог, емко охарактеризованный М. Бахтиным: «Единство культуры, - писал он, - это открытое единство. Чужая культура только в глазах другой культуры раскрывает себя полней и глубже, но не во всей полноте, потому что придут и другие культуры, которые увидят и поймут еще 
больше». [1, с. 332] В поликультурном обществе с особой остротой возникают вопросы о национальных особенностях образования. Проблема национальной специфики образования всегда стояла остро. Теоретическое осмысление новой концепции образования ведет к осознанию необходимости разработки новых, инновационных моделей высшего образования и подготовки на их основе специалистов, способных профессионально осуществлять свою деятельность в новых социально-исторических условиях, овладевать не только сугубо специальными знаниями в конкретной области, но также иметь возможность выражать полученные знания на иностранном языке, передавать их другим народам и культурам.

Идея поликультурного образования базируется на реализации модели непрерывного образования, основными целями которого являются:

- формирование осознанных позитивных ценностных ориентаций личности учащегося по отношению к собственной культуре;

- воспитание уважения к истории и культуре другого народа;

- создание поликультурной среды как основы для взаимодействия личности с элементами других культур;

- формирование способности учащегося к личностному культурному самоопределению.

Основополагающими принципами поликультурного образования являются:

— принцип диалога и взаимодействия культур; контрастивный принцип овладения содержанием поликультурного образования; принцип творческой целесообразности потребления, сохранения и создания новых культурных ценностей.

Главной задачей поликультурного образования О.В. Аракелян признает воспитание культуры межнационального общения, акцентируя внимание на уважительном отношении к Другим культурам, Другим людям и определяя толерантность лишь как терпимость. В то же время, по ее мнению, в школе нужно не терпеть друг друга, а уважать, учитывать поликультурный принцип в общении, а это требует специальной организационной работы. [2, с. 112]

Цели поликультурного воспитания: обеспечение поликультурного просвещения; приобщение к культуре своего этносоциума (а, значит, сохранение национальных культур), обучение общению. Средствами их реализации в поликультурной школе становятся: изучение предметов этноцикла, а также учебных дисциплин блока «Культура мира» (этнология, этнопсихология, культурология, Россиеведение и др.); изучение каждым ребенком родного языка и культуры; знакомство с культурой своих сверстников.

Таким образом, ключевыми позициями в поликультурном развитии личности современные педагоги называют уважение культуры другого, ее понимание и толерантное отношение к представителю иной культуры.

Важнейшей задачей процесса становления поликультурной личности является признание другой культуры как альтернативной формы бытия.
Педагог контролирует деятельность учащихся по нескольким направлениям:

- развитие навыков и умений ребенка в конкретной области знания в контексте поликультурной среды;

— получение и усвоение знаний о поликультурной среде;

- формирование рефлексивной культуры.

Самыми главными и наиболее эффективными методами контроля практической деятельности учащихся являются такие методы контроля, как написание эссе, заполнение анкет, проведение тестирования и т.д.

Педагог как субъект образовательного процесса обеспечивает воздействие на ученика как субъекта образовательного процесса, разрабатывает системный подход при изучении многих социальных явлений, учитывает социокультурную реальность и этнокультурные характеристики ребенка. При этом ученик становится активным субъектом обучения. Внимание педагога направлено на включение ребенка в учебную деятельность, признание его индивидуальных особенностей, формирование у него самостоятельного мышления, суждения и поступков, независимо от авторитетов. Таким образом, во главу угла ставится личность ребенка как субъекта взаимодействия в процессе обучения и культурного развития. Для этого разрабатываются методы теоретического анализа, проводится экспериментальная работа, апробируются методики внедрения концепции поликультурного образования учащихся на базе учебных дисциплин. Қак уже указывалось выше, активно используются методы тестирования, анкетирования учащихся, а также проведение интерактивных бесед, дискуссии, семинаров, круглых столов и кейсов. Особая роль в этом процессе отводится родителям как еще одному субъекту 一 участ нику образовательного процесса в условиях поликультурного общества. Взаимодействие с родителями заключается в том, что именно педагог готовит взрослых к новой роли - роли родителей ребенка, обучающегося в поликультурной среде. Оно осуществляется через всевозможные педагогические приемы. Семинары для родителей, консультации по вопросам учебно-воспитательной деятельности, открытые уроки, дни открытых дверей, мастер-классы, психологические тренинги и т.д. В результате родители становятся субъектом образовательного процесса. Что в условиях поликультурной среды становится особенно важным, поскольку они, со своей стороны (педагог - с другой стороны) оказывают необходимую помощь и поддержку своему ребенку в процессе его становления как личности, способной выстоять и противостоять не только трудностям жизни в условиях многонационального общества, но и оставаться человеком с большой буквы, иными словами, быть готовым к пониманию и уважению иных культур.

Таким образом, при взаимодействии всех субъектов образовательного процесса - педагога - ученика родителей - реализуется главная цель образования учащихся - подготовка достойных членов общества, которое сегодня представляет собой многонациональное государство. Взаимодействие субъектов процесса образования обусловлено сущностью поликультурного образования, которая заключается в том, что феномен «по- 
ликультурное образование» - специфическое явление педагогической деятельности, направленной на формирование у учащихся социокультурной идентичности, а также представлений о поликультурном пространстве, о развитии многонационального общества и о деятельности в реалиях такого общества. Цель процесса образования в таких условиях определяется именно формированием индивида. Готового к активной созидательной деятельности в современной поликультурной среде, со- храняющего свою социально-культурную идентичность, уважающего и принимающего другие культурно-этнические общности, живущего в мире и согласии с представителями других национальностей.

На этой базе выстраивается диалог взаимных интересов. Важность такого образования состоит в том, что оно формирует личность, открытую для общения, а главное - ведет к снижению социальной напряженности в обществе.

Литература:

1. Бахтин, М. М. Эстетика словесного творчества. М., 1979. с. 332.

2. Баскакова, Н.П., Ефремова Н.В. Язык и музыка в поликультурном образовании / Россия и Запад: диалог культур. Материалы 4-й Международной конференции. М.: МГУ, 1998. с. 112-119.

\title{
About problem-based learning at lessons of mathematics
}

\author{
Дружинин Константин Петрович, студент; \\ Куимова Марина Валерьевна, кандидат педагогических наук, доцент \\ Национальный исследовательский Томский политехнический университет \\ Druzhinin Konstantin Petrovich, student \\ Kuimova Marina Valeryevna, PhD in Methods of TFL \\ National research Tomsk polytechnic university
}

The majority see the obstacles; the few see the objectives; history records the successes of the latter, while oblivion is the reward of the former.

Alfred Armand Montape

$\mathrm{T}$ here is no doubt that higher education and research are a moving force for innovations and country development. Increased international cooperation, the need to establish new business contracts and their effective maintenance require specialists who can solve different professional problems independently. Technical universities should prepare engineers with a high enough level of knowledge about modern technologies and foster a love for lifelong learning. To achieve these goals, universities use various innovative teaching methods and approaches. Problem-based learning is one of them. In general, it includes:

- problem identification;

— avoidance of giving ready-made answers;

— interaction between learners and the teacher;

- teacher guidance and coaching of the problem-solving;

- teaching within a context $[12,14,15]$.

Problem-based learning is indented to the acquisition of new knowledge through the solution of theoretical and practical tasks. The majority of scholars agree that problem-based learning includes several stages:

- general awareness of the problem;

- analysis of the problem;

- solution (development, justification of a hypothesis, its sequential check);
- decision verification $[4,7,10,11]$.

Considering advantages of problem-based learning, researchers state that it:

- stimulates interest in cognitive activity;

- exercises the capacity for work and encourages to learn new materials when solving problems;

- develops abilities to formulate the problem;

- develops problem-solving and critical thinking skills;

- enables to see events multi-dimensionally and with a deeper perspective;

- contributes to the development of creative skills;

- develops time management skills;

- develops the ability to respond to unexpected situations [13, 15].

Problem-based learning is aimed at preparing students for future problems in their learning environment and producing appropriate solutions to problems [11].

When choosing tasks, a teacher should remember that they should:

- be realistic;

— be open-ended, imply a "multiple-choice";

- evoke curiosity.

The successful use of problem-based learning requires the correspondence of the tasks to students': 
— intellectual abilities;

— individual peculiarities and age interests;

- knowledge of the subject.

Problem-based learning anticipates:

- teacher-learner, learner and learner exchanges;

- teacher guidance;

— rich material and research;

— friendly learning environment;

- theoretical or practical tasks which suppose the acquisition of new knowledge and skills.

Problem tasks set learners before certain difficulties demanding considerable mental effort leading to a solution. They are directed at placing a learner in a difficult situation which he has to overcome. The majority of exercises presented in teaching materials and textbooks for mathematics are tasks oriented towards thinking rather than simple sample training [5, 9].

Problem tasks at lessons of mathematics favour the formation of logical, creative thinking, teach to reformulate, uncover logical connections between theories, generalize studied ma- terial, develop mathematical thinking alongside the knowledge and contribute to the practical use of mathematics [2]. The use of these tasks encourages cognitive development, trains to identify, generalize, specialize and clarify problems [6].

Besides the use of problem tasks at lessons of mathematics contributes to the formation of intellectual abilities, research skills, abstraction and generalization skills, encourages inquisitiveness, curiosity and independence [1, 3, 8].

Problem-based learning enables practical application of knowledge, advances the role of creative and cognitive work. However, it should be noted that a teacher can't use only one method, he should combine elements of different methods to achieve greater results while teaching his subject.

Nowadays much attention is paid to the development of a strong creative personality, the ability to solve problems independently and find ingenious solutions. Problem-based learning in teaching mathematics helps to solve unconventional tasks, develops high level of critical thinking skills, motivates leaning and prepares to meet everyday challenges.

\section{References:}

1. Бирючкова Н. С. Проблемное обучение математике и его приоритеты // В сборнике: Инновационное развитие образования в регионах Российской Федерации сборник материалов Всероссийской научно-практической конференции. Под редакцией Л. К. Гребенкиной, А. А. Петренко, Т. В. Ганиной. Рязань, 2013. с. $338-340$.

2. Валиуллина Р.Н. Формирование познавательной активности учащихся на уроках математики через использование элементов проблемного обучения в средней школе // Вестник Башкирского университета. 2012. Т. 17. № 4. с. 1886 - 1888.

3. Гончарова М.А., Решетникова Р.Н. Проблемное обучение на уроках математики // Школьные технологии. 2013. № 2. c. 96-105.

4. Демченкова Н.А. Проблемное обучение математике как средство реализации исследовательской деятельности в вузе // Социальная политика и социология. 2011. № 2. с. 248-261.

5. Ж Жданова И.И. Проблемное обучение на уроках математики // В сборнике: Психодидактика высшего и среднего образования материалы девятой международной научно-практической конференции. Барнаул, 2012. с. 44-46.

6. Золотая И. Г. Использование проблемного обучения на уроках математики для развития творческого мышления // Психология и педагогика: методика и проблемы практического применения. 2012. № 25-1. с. $220-225$.

7. Корнева Г.Н. Проблемный подход в обучении математике // Наука и образование в XXI веке. Сборник научных трудов по материалам Международной научно-практической конференции 30 января 2015 г.: в 5 частях. ООО «АР-Консалт». Москва, 2015. с. 25-26.

8. Лунгу К.Н. Формирование приемов учебной деятельности студентов при проблемном обучении математике // Вестник Российского университета дружбы народов. Серия: Психология и педагогика. 2007. № 3-4. с. 182-188.

9. Першина Н.А. Проблемные ситуации как инструмент формирования познавательного интереса при обучении математике // Вектор науки Тольяттинского государственного университета. Серия: Педагогика, психология. 2013. № 1 (12). c. 183-185.

10. Ситаров В.А. Проблемное обучение как одно из направлений современных технологий обучения // Знание. Понимание. Умение. 2009. № 1. с. 148-157.

11. Akinoglu O., Tandogan R. O. The effects of problem-based active learning in science education on students' academic achievement, attitude and concept learning // Eurasia journal of mathematics, science \& technology education, 2007, 3 (1). P. 71-81.

12. Chin Ch., Chia Li-Gek Problem-based learning: using students' questions to drive knowledge construction // Science Education, 2004, Vol. 88, Issue 5, P. 707-727.

13. Gallagher Sh.A., Sher B. T., Stepien W. J., Workman D. Implementing problem-based learning in science classrooms // School science and mathematics. 1995. Vol. 95, Issue 3. P. 136-146.

14. Grasel C., Fischer F., Mandl H. The use of additional information in problem-oriented learning environments // Learning Environments Research. 2000. T. 3. № 3. P. 287-305.

15. Taplin M. Mathematics through problem solving. http://www.mathgoodies.com/articles/problem_solving.html (accessed February 28, 2015). 


\section{Направления целеполагания студента вуза в сфере саморазвития}

Егорова Юлия Александровна, кандидат педагогических наук, доцент

Казанский (Приволжский) федеральный университет, филиал в г. Чистополе

В статье выделены и рассмотрены три направления целеполагания студента вуза в сфере саморазвития: интеллектуальное, социокультурное и профессиональное.

Ключевые слова: саморазвитие, интеллектуальное саморазвитие, социокультурное саморазвитие, профессиональное саморазвитие, цель.

Человек есть центр и цель своей жизни... развитие своей личности, реализация всего внутреннего потенциала есть наивысшая цель, которая просто не может меняться или зависеть от других якобы высших целей.

$\mathrm{B}$ психолого-педагогической литературе существуют различные трактовки понятия саморазвития: 1 ) развитие собственных сил, физических и умственных, на основе самодеятельности, самостоятельных занятий; 2) развитие, происходящее силой внутренних причин, независимо от внешних факторов, самодвижение (филос.) [19]; необходимое самопроизвольное изменение личности, определяемое внутренними противоречиями [4, с. 47]; фундаментальная способность человека становиться и быть подлинным субъектом своей жизни, превращать собственную жизнедеятельность в предмет практического преобразования [18]; творческое отношение индивида к самому себе, создание им самого себя в процессе активного воздействия на внешний и внутренний мир с целью его преобразования [2]; необходимое условие формирования профессионально значимых личностных качеств [13, с. 172]; процесс обогащения деятельностных способностей и иных личностных качеств человека в ходе различных видов его целесообразной деятельности, основанием которого служат распредмечивание (присвоение) социального опыта и достижений культуры, воплощенных в реалиях, вовлекаемых в процесс той или иной деятельности; сознательное управление своим развитием [10]. Саморазвитие это одна из сложнысх форм работы внутреннего мира, в том числе и по преобразованию самого внутреннего мира, наряду с переработкой опыта, выработкой собственных позиций и убеждений, постановкой жизненных целей, поиском путей самоопределения. И все это осуществляется в процессе продвижения человека по своему жизненному пути, в рамках которого личность обнаруживает себя, строит себя, постигает смысл своего существования (Маралов В. Г.).

Для обеспечения эффективности и качества собственной учебной, социокультурной и профессионально-ориентированной (трудовой) деятельности, студент должен осуществлять интеллектуальное, социокультурное и профессиональное саморазвитие; определять цели и задачи в сфере саморазвития.

Интеллектуальное саморазвитие включает самостоятельное развитие студентом интеллектуальной компетентности. Интеллектуальная компетентность явилась предметом исследования О.Г. Берестеневой, В.Н. Введенского, И.А. Зимней, С.В. Злобина, Н.В.Козловой, А. К. Марковой, Л.А. Сивицкой, А.Н. Тубельского, Д. Хапт, А.В. Хуторского, О.Н. Ярыгина и др., каждый из которых внес свой весомый вклад в изучение ее сущностных характеристик. Учеными установлено, что в становлении профессионала (профессионализма личности) интеллектуальная компетентность является базовой, ее формирование обеспечивает основу для: освоения студентами всех компонентов общепредметного содержания образования; решения разнообразных жизненных и профессиональных проблем, преодоления стереотипов и шаблонов мышления; развития способностей к гибкому вариативному восприятию и оценке происходящих событий, рефлексии и закрепления опыта эффективной деятельности и успешности в конкурентной среде [14, с. 10].

Интеллектуальная компетентность рассматривается учеными как:

- готовность к осуществлению различных видов познавательной деятельности и решению разнообразных житейских и профессиональных проблем [7, с. 9];

- единство интеллектуальных способностей и креативности [11, с. 11$]$;

- способность приобретать и применять знания для саморегуляции и установления взаимоотношений;

- наличие аналитических навыков в сочетании с умением мыслить в категориях комплексных взаимосвязей;

- единство логических приемов умственной деятельности, интеллектуальных способностей, креативности и способности к самообразованию и самовоспитанию [9, с. 8];

- метаспособность, которая, определяя меру освоения субъектом некоторой предметной области, характеризуется особым типом организации предметно-специфических знаний и эффективными стратегиями принятия решений в данной предметной области; тип организации знаний, обеспечивающий возможность принятия эффективных решений в определенной предметной области деятельности [11, с. 4];

- способность к выполнению мыслительных операций, выраженная в приобретении, применении и пре- 
образовании знаний для саморегуляции; умение осуществлять сопоставление, сравнение, структурирование, анализ, обобщение, классификацию, синтез, моделирование и оценивание [12, с. 13];

- метакачество, обеспечивающее возможность ставить и эффективно решать проблемы разного уровня сложности, готовность мобилизовать свои интеллектуальные компетенции и личностные качества для решения профессиональных задач на основе актуализации индивидуального опыта [14, с. 21$]$.

Формирование интеллектуальной компетентности обеспечивает фундамент для освоения всех образовательных областей без исключения [14].

Компоненты интеллектуальной компетентности:

- по Сагдеевой Г. С.: мотивационный (готовность к развитию и саморазвитию, мотивированность на самопознание и самосовершенствование, установка на преодоление противоречий); когнитивный (умение работать с информацией: умение поиска, структурирования, преобразования, перевода информации из одного способа кодирования в другой, выделения главного и второстепенного, умение делать обобщения, выводы, способности к составлению когнитивных схем мыслительной деятельности, алгоритмов решения задач); метакогнитивный (представлен умениями и навыками самоорганизации и самоуправления: умение ставить цели, осуществлять планирование познавательной деятельности, оценку, контроль, рефлексивный анализ и способности к самооценке) $[14$, с. 21$]$;

- по Ярыгину О.Н.: алгоритмическая, дедуктивная (логическая), индуктивная и языковая компетентности $[11$, с. 11$]$.

В качестве критериев сформированности интеллектуальной компетентности Костровой Ю. С. [9, с. 12] выделены:

- репродуктивные знания, которыми обладает специалист-выпускник; владение основными мыслительными операциями - низкий уровень;

- применение знаний в нестандартных ситуациях, умение ставить и решать профессиональные задачи, осуществляя необходимую поисково-познавательную деятельность; умение вести учебный диалог - средний уровень;

- командная работа; способность адекватно оценивать результаты своей работы - уровень выше среднего;

- устойчивая мотивация к выполнению профессиональной деятельности, обеспечивающая ее высокую эффективность; способность к самообразованию - высокий уровень.

Примерные цели студента в сфере интеллектуального саморазвития: «развитие восприятия», «развитие внимания» (умения продолжительное время работать с предельным вниманием, концентрировать внимание на учебном процессе), «развитие памяти» (умения не только хорошо усвоить и сохранить в памяти необходимые в будущем знания, но и быть всегда готовым к быстрому и точ- ному их воспроизведению в условиях профессиональной деятельности; овладение эффективными приемами запоминания), «развитие профессиональных представлений» (их полноты, правильности, ясности, прочности, яркости), «развитие профессионального воображения» (его силы, точности, активности, самостоятельности), «развитие профессионального мышления» (его глубины, гибкости, быстроты, точности; умения анализировать, осуществлять операции синтеза, абстрагирования, конкретизации, классификации, систематизации), «развитие познавательной самостоятельности», «развитие интеллектуальной активности» (самостоятельности, инициативы, оригинальности в поиске решений), «развитие профессиональной речи» (ее эмоциональной выразительности, смысловой точности, ясности, краткости, понятности, объективности).

Социокультурное саморазвитие включает самостоятельное развитие студентом социальной компетентности. Специалисты считают, что термин «социальная компетентность» может рассматриваться как общее собирательное понятие, свидетельствующее об уровне социализации личности [20].

Социальная компетентность - это:

- интегративное социальное качество личности, включающее в свой состав субъективную способность к самодетерминации, самоопределению, самоуправлению и самоутверждению, базирующееся на ясном ценностном понимании действительности, конкретном категориальном знании как руководстве к действию, умении осуществлять социальные технологии в главной сфере жизнедеятельности (в системе социальных институтов, норм и отношений согласно должному уровню культуры, нравственности и права).

Социальная компетентность означает социальную зрелость человека, высший уровень адаптации личности, позволяющий ей эффективно выполнять свои жизненные роли, моделировать свою деятельность в обществе в определенных ценностных ориентирах. Социальная зрелость в полном объеме предполагает духовную зрелость личности, которая базируется на общечеловеческих ценностях, вклю чает в себя основные компоненты общественного самосознания - нравственное, политико-правовое, религиозное, историческое, национальное (Черноусов И. В. ) [20, с. 10];

- готовность и способность человека формироваться и жить в социальном взаимодействии» (Байденко В.И.) [1, с. 19];

- личностное свойство, обеспечивающее взаимодействие человека с миром на основе его отношения к себе, к обществу, к другим, к деятельности; понимание человеком отношений «Я и мир», «Я и общество», умение выбрать социальные ориентиры и умение организовать свою деятельность в соответствии с этими ориентирами; социальная методология личности, направляющая и регулирующая конкретным образом все социальные проявления человека, его внутренний и внешний опыт [20, с. 31 ].

Социальная компетентность является личностно и социально обусловленным обобщенным качеством, имеет дво- 
якую природу. С одной стороны, она связана с процессами адаптации и социализации личности, с другой - личностно обусловлена и потому представляет собой выход на самореализацию личности в профессиональной деятельности. Социальная компетентность должна рассматриваться на уровне особенного, она имеет собственные разновидности ( социально-перцептивная, социально-психологическая, социально-коммуникативная), а ее структура имеет сложную организацию и включает в себя несколько компонентов: личностные и профессионально важные качества; профессиональные знания и умения; навыки социальной жизнедеятельности; личностно обусловленные нравственные ценности и др. (Бочаров В. М.) [3, с. 18-19].

В контексте системно-деятельностного подхода социальная компетентность представляет собой знание в действии и выступает как целостное интегративное личностное образование, включающее когнитивный, поведенческий и мотивационно-ценностный компоненты. Она позволяет человеку быть успешным в его жизнедеятельности и возникает как психологический продукт социальной ситуации развития - специфической системы отношений среды и субъекта, отраженный в его переживаниях и реализуемый в совместной деятельности с другими людьми (Жиганов Б. А. ) [8].

Примерные цели студента в сфере социокультурного саморазвития: «развитие социальной активности», «развитие коммуникабельности», «развитие лидерского потенциала», «развитие социальной ответственности», «формирование готовности к семье и браку», «формирование ответственности за брачно-семейные отношения», «развитие готовности к ответственному родительству», «развитие толерантности», «развитие способности к рациональной организации досуга», «развитие стрессоустойчивости».

Профессиональное саморазвитие включает самостоятельное развитие студентом профессиональной компетентности. В значительном числе исследований в области педагогики и психологии (Н.В. Андронов, Л.И. Анциферова, Ю.В. Варданян, Е.Н. Волкова, Э.Ф. Зеер, И.А. Зимняя, И.А. Колесникова, А.И. Щербаков и др.) неоднократно определялась структура и содержание профессиональной компетентности, выделялись педагогические, психологические, методические, социальные факторы и условия ее формирования и развития. Существующие на сегодняшний день в зарубежной и отечественной литературе определения понятия профессиональной компетентности синонимичны таким понятиям, как «углубленные знания», «состояние адекватности выполнения задач», «способность к профессиональной деятельности». Профессиональная компетентность в самом общем значении характеризует способность специалиста самостоятельно ставить и решать новые профессиональные задачи (Георге И. В.) [5, с. 3]. Компетентность предполагает постоянное обновление знаний, овладение новой информацией для успешного применения в конкретных условиях, то есть овладение оперативными и мобильными знаниями. Компетентный специалист должен знать не только существо проблемы, но и уметь решать ее практически. Қомпетентного специалиста отличает способность среди множества решений выбирать наиболее оптимальное, аргументированно опровергать ложные, подвергать сомнению эффектные, но не эффективные решения, то есть он должен обладать критическим мышлением и способностью к творчеству (Чошанов М. А. ) [22, с. 56-57].

Профессиональная компетентность - это:

- соответствие знаний, умений и производственных навыков, а также всей ценностной системы человека уровню общественных ожиданий от данной профессии, качеству социальной и профессиональной среды;

- мерило деловых качеств человека; характеризует его личностные и социальные возможности, способность выбирать оптимальные и соответствующие конкретной ситуации способы деятельности, предполагает ряд способностей к взаимодействию.

Одной из характеристик профессиональной компетентности личности является ее нравственная компонента, носящая императивный характер: современный профессионал должен обладать не только некоторой суммой знаний, умений и производственных навыков, но и развитым нравственным сознанием, включающим в себя, наряду с общеморальными установками, профессиональные ценности - чувство профессионального долга, профессиональную совесть, профессиональную честь, профессиональное достоинство, профессиональную ответственность (Черноусов И. В. ) [20, с. 11 ];

- интегративное качество личности, система необходимых знаний, умений и навыков, обеспечивающих готовность и способность выполнять самостоятельно профессиональные функции в соответствии с принятыми в социуме в конкретно-исторический момент нормами, стандартами и требованиями (Георге И. В. ) [5, с. 10];

- интегральный критерий качества профессионального обучения, профессиональной деятельности; свойство личности, для которой характерны высокое качество выполнения трудовых функций, культура труда и межличностных коммуникаций, умение инициативно и творчески решать профессиональные проблемы, владеть многоплановыми аспектами деятельности, готовность к предприимчивости и принятию управленческих решений, к адаптации к новым условиям деятельности [17];

- полиаспектная характеристика специалиста, включающая совокупность когнитивных, операционально-технологических, мотивационно-волевых и коммуникативных составляющих, отражающих уровень его способности к эффективному выполнению профессиональной деятельности и степень готовности к профессиональному развитию в условиях динамики, повышения наукоемкости профессионального труда и возрастания личной ответственности за его результаты [6, с. 68]; составляющими профессиональной компетентности выступают необходимые для выполнения конкретной профессиональной деятельности знания, умения, профессионально значимые качества, опыт, направленность личности и др. (Гнатышина Е.А.) [6, с. 126]; 
- совокупность личностных, социальных, профессиональных и иных компетенций, которые требуются индивиду для решения конкретных профессиональных задач (Маркова А.К.) [15, с. 51-52]. Под профессиональными компетенциями Е.А. Гнатышина понимает интегральные внутриличностные свойства специалиста, включающие предметно-когнитивную, предметно-технологическую, предметно-мотивационную и предметно-коммуникативную составляющие, совокупность которых обеспечивает успешность выполнения конкретных видов профессионального труда и возможность углубленного совершенствования в отдельных из этих видов в зависимости от индивидуальных склонностей и предпочтений [6, с. 68].

А.К. Маркова выделяет следующие виды профессиональных компетенций: специальная (владение собственно профессиональной деятельностью на достаточно высоком уровне, способность проектировать свое дальнейшее профессиональное развитие), социальная (владение совместной, в частности групповой и кооперативной профессиональной деятельностью, сотрудничеством, а также принятыми в данной профессии приемами профессионального общения, социальная ответственность за результаты своего профессионального труда), личностная (владение приемами личностного самовыражения и саморазвития, средствами противостояния профессиональным деформациям личности), индивидуальная (владение приемами самореализации и развития индивидуальности в рамках профессии, готовность к профессиональному росту, способность к индивидуальному самосохранению, неподверженность профессиональному старению, умение организовать рационально свой труд без перегрузок времени и сил, осуществлять труд ненапряженно, без усталости и даже с освежающим эффектом) [15].

В структуре профессиональной компетентности студентов И. В. Георге выделила следующие компоненты:
— мотивационно-ценностный: отражает личностное отношение студента к профессиональной деятельности, его чувства, эмоции, личностные приоритеты. Проявление эмоционально-волевой активности включает эмоциональность как положительный эмоциональный фактор (реакция на успех и неудачу) и эмотивность (ценностный показатель осознанности субъектом необходимости профессиональной деятельности, положительное активное эмоционально окрашенное отношение к личностному и профессиональному самосовершенствованию);

- когнитивный (знание и понимание): отражает владение студентом общенаучными, общепрофессиональными и специальными знаниями, его интеллектуальную вовлеченность, открытость для приобретения новых знаний;

- деятельностный: отражает сформированность общепрофессиональных (учебных, рефлексивных, коммуникативных и др.) и специализированных (практические навыки, современные технологии и методы решения профессиональных задач различного уровня сложности) умений и навыков и способность их эффективного применения, развития и совершенствования в профессиональной деятельности [5, с. 11-12].

Примерные цели студента в сфере профессионального саморазвития: «развитие профессиональной направленности», «развитие профессионального самосознания», «развитие профессионального мышления», «развитие профессионального кругозора», «развитие профессиональной культуры», «формирование готовности к профессиональной деятельности», «развитие профессионально необходимых умений и навыков».

Формирование компетентности целеполагания в сфере саморазвития у студентов вуза возможно как в рамках обязательных учебных предметов, так и в рамках авторского спецкурса, лекции-семинара, практикума, тренинга.

\section{Литература:}

1. Байденко, В.И. Компетентностный подход к проектированию образовательных стандартов высшего профессионального образования (методологические и методические вопросы). - M., 2005.

2. Битянова, Н.Р. Психология личностного роста. - М., 1995

3. Бочаров, В. М. Система формирования социальной компетентности специалиста органов внутренних дел в процессе профессиональной подготовки: дис... д-ра пед. наук: 13.00.08. - Ставрополь, 2005.

4. Витвицкая, Л.А. Педагогический глоссарий: метод. пособие. - Оренбург, 1999.

5. Георге, И. В. Формирование профессиональной компетентности будущих специалистов на основе организации самостоятельной работы студентов при обучении в вузе: автореф. дис... канд. пед. наук: 13.00.08. — M., 2013.

6. Гнатышина, Е.А. Компетентностно ориентированное управление подготовкой педагогов профессионального обучения: Монография. - СПб.: ООО «Книжный Дом», 2008.

7. Гончаров, В.С. Психолого-педагогическое проектирование когнитивного развития школьников: дис... д-ра психол. наук: 19.00.07. - Курган, 2006.

8. Жиганов, Б. А. О роли социальной компетентности личности в повышении эффективности управленческих кадров в сфере образования: дис... канд. психол. наук: 19.00.07. - М., 2007.

9. Кострова, Ю.С. Формирование интеллектуальной компетентности студентов посредством использования метода проектов в процессе изучения математики в негуманитарном вузе: автореф. дис... канд. пед. наук: 13.00.01. - Рязань, 2012.

10. Куликова, Л.Н. Общение как фактор взаимосвязанного развития личности и деятельности сообщества // Личность в воспитательной системе учебного заведения. — Хабаровск: Изд-во ХГПИ, 1993. — c. 44-47. 
11. Марчук, Е.Г. Формирование интеллектуальной компетентности старшеклассников в образовательном процессе: автореф. дис... канд. пед. наук: 13.00.01. - Саратов, 2013.

12. Матвеева, Т.Е. Формирование информационно-интеллектуальной компетентности школьников посредством развивающей системы учебных заданий: автореф. дис... канд. пед. наук: 13.00.01.— Великий Новгород, 2012.

13. Розумовський, О.М. Професіоналізм та майстерність вчителя. - К., 2001.

14. Сагдеева, Г. С. Развитие интеллектуальной компетентности будущих специалистов (на примере подготовки инженеров-электриков): автореф. дис... канд. пед. наук: 13.00.08. - Казань, 2013.

15. Сафиуллина, Ф.Р. Трудовая занятость студенческой молодежи как социальный фактор формирования профессиональных компетенций: дис... канд. социол. наук: 22.00.03. - Саратов, 2014.

16. Сауренко, Н.Е. Проектная деятельность как средство формирования творческой активности студентов колледжа: дис... канд. пед. наук. - М., 2004.

17. Сибирская, М.П. Педагогические технологии и повышение квалификации инженерно-педагогических кадров. - СПб.: Изд-во ЦИИКРР, 1997.

18. Слободчиков, В.И., Исаев Е.И. Психология развития человека. - М., 2000.

19. Толковый словарь русского языка: в 4 т. / под ред. Д. Н. Ушакова. М., 1935-1940 [электронный ресурс]. Режим доступа. - URL: http://slovari.yandex.ru.

20. Черноусов, И. В. Становление социальной и профессиональной компетентностей личности в современном образовательном пространстве: дис... канд. филос. наук: 09.00.11. - Воронеж, 2007.

21. Чошанов, М.А. Дидактическое конструирование гибкой технологии обучения // Педагогика.— 1997.№ 2. - c. $19-24$.

22. Шаповал, А. И. Активизация учебно-познавательной деятельности студентов вузов на основе группового взаимодействия: дис... канд. пед. наук: 13.00.08. - Магнитогорск, 2005.

\title{
Сущность категории «здоровый образ жизни детей дошкольного возраста» и факторы формирования здорового образа жизни дошкольников в контексте педагогических исследований второй половины XX века
}

\author{
Жерякова Светлана Валерьевна, воспитатель \\ МБДОУ детский сад комбинированного вида «Сказка» (ХМАО - Югра)
}

$\mathrm{P}$ азвитие нашего государства обусловило радикальные изменения в мировоззрении и идеологии, в культуре и образовании, среди которых проблема здорового образа жизни человека определяется как стратегическая и масштабная.

Акцентирование внимания на проблемах здоровья обусловлено его необходимостью для успешного функционирования и прогресса социокультурных, общественных и политических структур в целом.

Анализ значительного количества научных трудов исследуемого периода дает основания констатировать, что во второй половине XX века широко разрабатывались вопросы формирования навыков здорового образа жизни личности, содержания и методики физического воспитания дошкольников.

Проблема здорового образа жизни была предметом исследования ученых различных отраслей знаний:

- медицинской (Д. Давыденко, В. Волков, П. Половников);

- биомедицинской (Ю. Лисицын, А. Щетинин),

- социальной (О. Вакуленко, Л. Жалило, В. Қлимова, В. Скумин В. Яременко);
— психологической (В. Ананьев, В. Қлимова, С. Шапиро).

В педагогических трудах проблема здорового образа жизни рассматривалась в контексте повышения эффективности системы физического воспитания школьников и дошкольников (Е Вильчковський, Н. Денисенко, Т. Дмитренко, О. Дубогай).

В конце XX века определился валеологический подход к изучению проблем здорового образа жизни школьников (И. Брехман). Исследованы различные аспекты валеологического образования и валеологического воспитания школьников и молодежи (Т. Бойченко, О. Вакуленко, Г. Голобородько, А. Иванашко, С. Лапаенко, С. Свириденко, Л. Сущенко, С. Юрочкина). Выполнен ряд экспериментальных исследований по проблеме формирования навыков здорового образа жизни у детей дошкольного возраста (Н. Денисенко, В. Иванашко, С. Юрочкина). Определены условия профессиональной подготовки будущих специалистов дошкольного образования по воспитанию у детей навыков здорового образа жизни (В. Нестеренко).

Следовательно, проблема формирования навыков здорового образа жизни была в центре внимания ученых 
и практиков второй половины XX века. Именно в этот период накоплен немалый опыт ее решения. Однако, целостного анализа проблема формирования навыков здорового образа жизни у детей дошкольного возраста в период второй половины XX века в современных научных исследованиях не получила.

Учитывая остроту социальной потребности в сохранении здоровья каждого ребенка, целесообразность решения этой проблемы средствами образования и недостаточный уровень освещения ее историко-педагогического аспекта было определено тему нашей статье: «Сущность категории «здоровый образ жизни детей дошкольного возраста» и факторы формирования здорового образа жизни дошкольников в контексте педагогических исследований второй половины XX века».

В процессе научного поиска установлено, что во второй половине XX века понятие «здоровье» в научно-педагогическом пространстве (В. Ананьев, Д. Давыденко, В. Петренко, Г. Хомутов) рассматривается как целостный, системный феномен, характеризующий внутреннюю сущность жизни и ее качественное состояние, выражает уровень духовного, психического, физического и социального благополучия индивидуума [5].

Здоровье связано с образом жизни человека, как с устойчивой формой его социальной жизни, моделью поведения и взаимодействия с окружающим миром. В исследовании понятие «здоровый образ жизни» обозначено как жизнедеятельность, направленна на сохранение и улучшение здоровья людей.

Современные исследования (Д. Венедиктов, Е. Жук, Ю. Лисицын, А. Царик) рассматривают понятие «здоровый образ жизни»в неотъемлемой связи с личностно-мотивационным компонентом личности, как условие и возможность реализации индивидом своих социальных, психологических, физических способностей. Навыки здорового образа жизни усваиваются человеком под влиянием социальных мега-, макро-, мезо-, микрофакторов в течение всей жизни. Особое место в процессе формирования здорового образа жизни занимает социализация личности путем усвоения определенных норм поведения и образцов жизнедеятельности [6].

Здоровый образ жизни рассматривается в нашем исследовании как совокупность внешних и внутренних условий жизнедеятельности человеческого организма, основными составляющими которого являются: питание (требования к качеству питьевой воды, сбалансированного объема витаминов, микроэлементов, протеинов, жиров, углеводов), быт (гигиенически-санитарные условия помещения для труда и отдыха), двигательная активность.

Проведенное исследование дало возможность определить здоровый образ жизни детей дошкольного возраста как форму повседневной жизни, что отвечает гигиеническим правилам, развивает адаптивные возможности организма, способствует успешному поддержанию и развитию его резервных возможностей. Наиболее сенситивным для усвоения правил, норм, умений и навыков здорового образа жизни, культурно-гигиенических навыков является младший дошкольный возраст, как период интенсивного личностного развития, формирования самосознания, мотивов поведения, моральных качеств ребенка [1].

В процессе научного поиска было выяснено, что к особенностям дошкольного возраста необходимо отнести новообразования, центральными среди которых являются возникновение первого схематичного образа целостного детского мировоззрения; первичных этических понятий и норм, которые часто связаны с эстетическими чувствами; соподчинение мотивов, благодаря которым формируются такие качества личности, как настойчивость и умение преодолевать трудности; личной сознания и самосознания; произвольного поведения личности, что предполагает овладение средствами и эталонами сознательной деятельности, переход от эгоцентризма к децентрации [3].

Установлено, что биологические особенности развития ребенка дошкольного возраста связаны, прежде всего, с дальнейшим интенсивным созреванием его организма: в младшем дошкольном возрасте наблюдается замедление темпов увеличения роста и веса; растет общий вес мышц, совершенствуется деятельность сердечно-сосудистой системы, координация движений; происходят активные морфологические изменения в строении головного мозга, усиление регулятивной функции больших полушарий головного мозга; образуются и совершенствуются условные рефлексы, в которых ведущую роль играет слово. Необходимо заметить, что именно благодаря воспитанию и обучению интенсивные процессы формирования второй сигнальной системы создают необходимые предпосылки для усвоения новых форм социального опыта [3].

Среди социально-психологических особенностей, способствующих усвоению навыков здорового образа жизни дошкольников, необходимо отметить следующие: совместная деятельность с взрослыми и сверстниками, которые демонстрируют образцы поведения; склонность к воспроизведению, подражание поступкам взрослых из близкого окружения; выполнения правил поведения на основе усвоенных привычек [2].

Решающее значение в формировании навыков здорового образа жизни дошкольников имеет стимулирования со стороны взрослых, адекватное возрасту и потребностям ребенка. В поведении ребенка дошкольного возраста сохраняются и закрепляются в основном те черты, умения и навыки, которые постоянно получают поддержку (так называемое положительное подкрепление) [4].

Изучение и анализ теоретических вопросов формирования здорового образа жизни детей дошкольного возраста дали возможность утверждать, что эта проблема всегда была актуальной, решалась с учетом потребностей социально-гуманитарного стандарта общества и очерчивалась как базовая в построении комплекса интеллектуальных, физических, духовных, психологических, социальных аспектов жизнедеятельности человека. 
Литература:

1. Бехтерев, В.М. Личность и условия ее развития и здоровья / В. М. Бехтерев. - [2-е изд.]. - СПб., 1905. c. 43.

2. Бех, И.Д. Личностно-ориентированное воспитание: Науч. - метод. пособие / Иван Дмитриевич Бех / Институт содержания и методов обучения. - K., 1998. - 204 с. - Библиогр. с. 199-202.

3. Григоренко, В.Г. Теория мотивированных дифференциально-интегральных оптимумов педагогических факторов в физическом совершенствовании человека / В.Г. Григоренко. - М.: Фонд социальных изобретений России, 2000. - 226 с.

4. Дубогай, А. Д. Физкультура: мы и дети / Александра Дмитриевна Дубогай, Людмила Михайловна Мовчан.К.: Здоровье, 1989.- $140[2]$ с.

5. Малюкова, И.В. Большая энциклопедия оздоровительных гимнастик. - М.: АСТ. СПб «Сова», 2007.С.641-645.

6. Омельченко, С.А. Взаимодействие социальных институтов общества в формировании здорового образа жизни детей и подростков / С. А. Омельченко: Монография. - Луганск: Альма-матер, 2007. - 352 с.

\title{
Использование блоков Дьенеша в восприятии формы предметов и геометрических фигур детьми младшего дошкольного возраста
}

\author{
Жуйкова Тамара Павловна, кандидат педагогических наук, доцент; \\ Томчак Екатерина Валерьевна, студент \\ Хакасский государственный университет им. Н. Ф. Катанова (г. Абакан)
}

$\mathrm{O}$ дной из наиболее актуальных и важных задач подготовки детей к школе является развитие логического мышления и познавательных способностей дошкольников, формирование у них элементарных математических представлений, умений и навыков.

При поступлении в школу ребёнок должен уметь устанавливать идентичность предметов и их свойств тому или иному эталону. Однако у большинства детей отсутствует умение анализировать и дифференцировать воспринимаемые предметы. Это говорит о том, что в дошкольных образовательных учреждениях уделяется недостаточное внимание формированию представлений о сенсорных эталонах, в частности об эталонах формы - геометрических фигурах.

В исследованиях современных отечественных и зарубежных психологов и педагогов (В. В. Давыдов, В. В. Данилов, А.А. Столяр, А. М. Пышкало, В.Г. Житомирский, М. Фидлер, В. Лаксон и др.) подчёркивается необходимость обучения детей обобщённым приёмам и способам анализа окружающей действительности по форме.

А.А. Столяр, А.М. Пышкало, В.Г. Житомирский, проблему знакомства детей с геометрическими фигурами и их свойствами рассматривали в двух аспектах: в плане сенсорного восприятия форм геометрических фигур и использования их как эталонов в познании форм окружающих предметов, а также в смысле познания особенностей их структуры, свойств, основных связей и закономерностей в их построении. [1]

Проанализировав точку зрения исследователей, мы пришли к выводу, что представление о форме предмета как границе между предметом и окружающим пространством возникает у детей очень рано. Геометрическая фигура это образец формы предмета, в соответствии с которым подбираются предметы окружающей действительности. По образцу могут выбирать дети и соответствующие геометрические фигуры. Младшие дошкольники свободно выбирают фигуру по данному им образцу, но при условии, если предлагаемые для выбора две фигуры контрастны по форме (квадрат и круг).

Так же необходимо как можно раньше обучать детей правильным приёмам обследования формы геометрической фигуры или предмета по их контурам, а для этого мы предлагаем наиболее эффективное пособие логические блоки, разработанные венгерским психологом и математиком Дьенешем для ранней логической пропедевтики, и, прежде всего для подготовки мышления детей к усвоению математики.

В методической и научно-популярной литературе этот материал можно встретить под разными названиями: «логические фигуры», «логические кубики», «логические блоки», но в каждом из названий подчеркивается направленность на развитие логического мышления. Плоский вариант логических блоков (логические фигуры) используется в современной начальной школе при изучении математики.

Логические блоки лучше изготовить из дерева или пластика. Примерные размеры больших и маленьких фигур (в сантиметрах) 

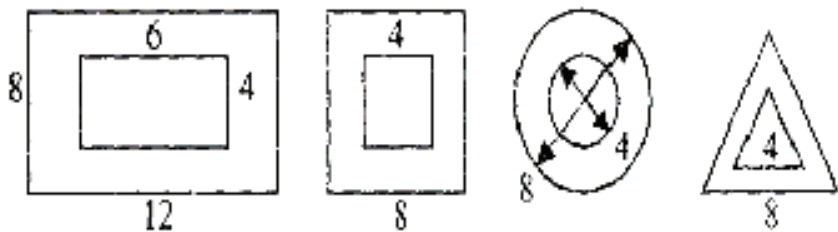

Толстые блоки должны быть толще тонких, по меньшей мере, в два раза.

Наборы плоских логических фигур можно сделать из картона или пластика по примеру логических блоков. Отличительная особенность таких наборов одинаковая толщина всех фигур.

Размеры фигур примерно (в сантиметрах)
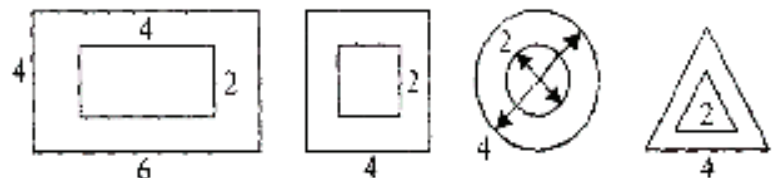

С логическими блоками ребенок выполняет различные действия: выкладывает, меняет местами. Далее убирает, прячет, ищет, делит между «поссорившимися» игрушками и т.д. По ходу выполнения действий ребенок рассуждает.

Игры и упражнения, с блоками проводятся в трёх вариантах.

Первый этап работы посвящается знакомству детей с блоками. Дети учатся выделять, называть, кодировать и декодировать свойства. Полученные знания, закреплять индивидуально, в совместной деятельности и самостоятельно в математическом уголке.

На втором этапе дети учатся группировать блоки по одному из названных свойств.

Третий (заключительный) этап работы отводится упражнениям детей в группировке блоков по двум свойствам [2].

Опишем основные моменты работы, например, воспитатель, сказала детям, что принесла новые кубики, каких у них еще не было. Она поставила четыре столика и высыпала на середину каждого из них разноцветные геометрические фигурки, предварительно рассмотренные по форме: на один стол — круги, на второй — треугольники, на третий — квадраты, на четвертый прямоугольники.

Переходя от стола к столу, детьми проверяли, сравнивали, называли фигуры. Здесь только квадраты, а на том столе лежат треугольники, а там круги и прямоугольники.

Ребенок, видя перед собой какую-либо геометрическую фигуру, перечислял ее признаки: форму, величину, толщину и цвет.

Второе задание направлено на складывание различных предметов из геометрических фигур Дьенеша. Большое познавательное значение имеет создание из блоков домиков, машинок, башен, скворечников и т.п.

В процессе постройки дети убеждаются, что во всем комплекте нет двух совершенно одинаковых геометрических фигур: если, например, геометрическая фигура является голубым толстым кругом, то все другие большие круги или не будут толстые, или толстые, но другого цвета. Если нужен маленький тонкий голубой треугольник, то он будет только один, другого голубого не найдется среди маленьких тонких треугольников [3].

Некоторым детям трудно строить из неодинаковых геометрических фигур Дьенеша, но есть такие дети, что прекрасно справляются с этими заданиями. Например, при постройки автомобиля они получают второе большое толстое красное колесо путем соединения двух тонких колес той же величины, одно из которых красное (оно кладется сверху). Получается, что покрышки этих двух колес одинаково толстые и что оба колеса красные.

Проверить, как дети усвоили свойства геометрических фигур, необходимо познакомить их со знаками кодирования, предложенный материал для дошкольников профессором А. Семадени [4, с.76-83].

Первый ряд — обозначение геометрических фигур; второй ряд — виды толщины (тонкий, толстый); третий ряд величину (маленький, большой); четвертый ряд — цвет (голубой, желтый, красный.

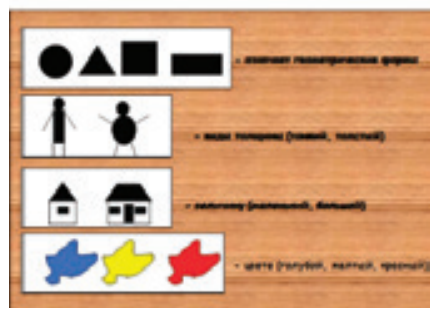


Примеры описания фигур

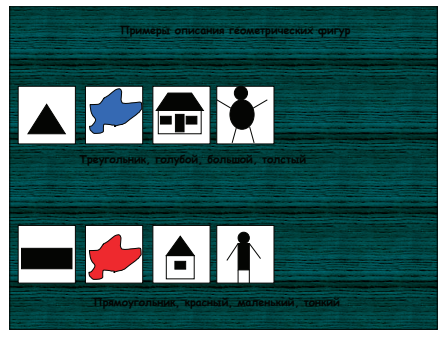

Схемы, составленные детьми
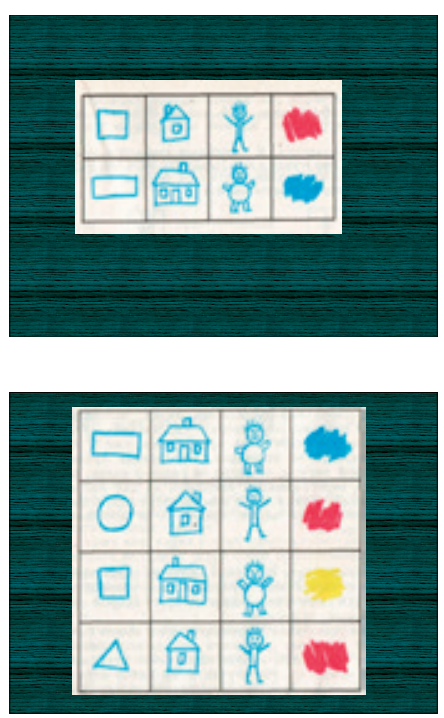

Описание геометрических фигур с отрицанием

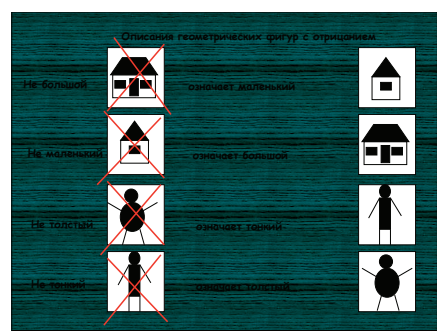

По схеме составить ряд геометрических фигур

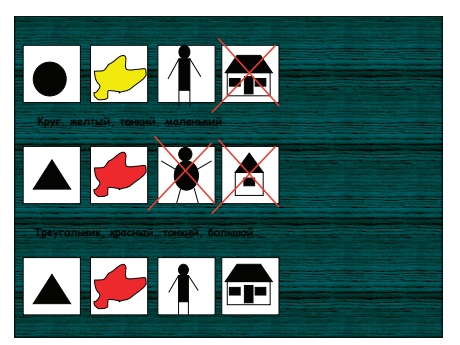

Упражнения организуются так, чтобы дети свободно пользовались кодом, знаками отрицания: синий красный желтый
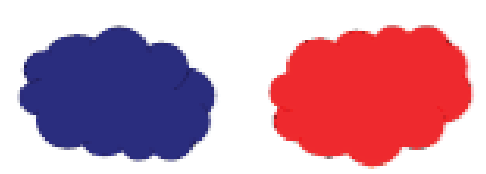
круглый квадратный треугольный прямоугольный
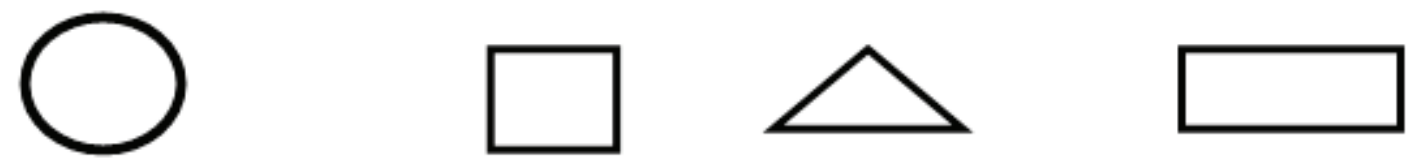

Большой с двумя окнами Маленький с одним окном
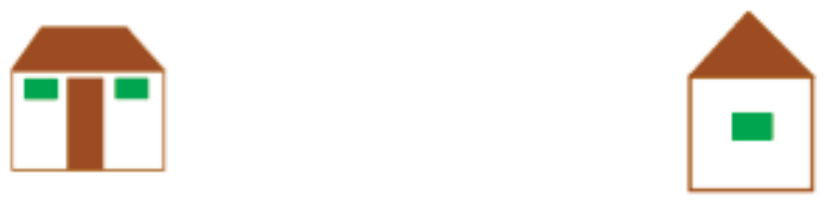

Толстый Тонкий
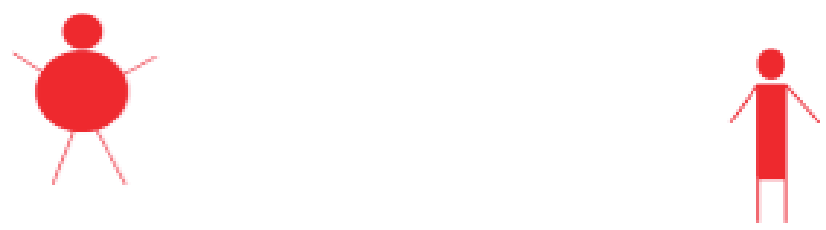

Знаки отрицания
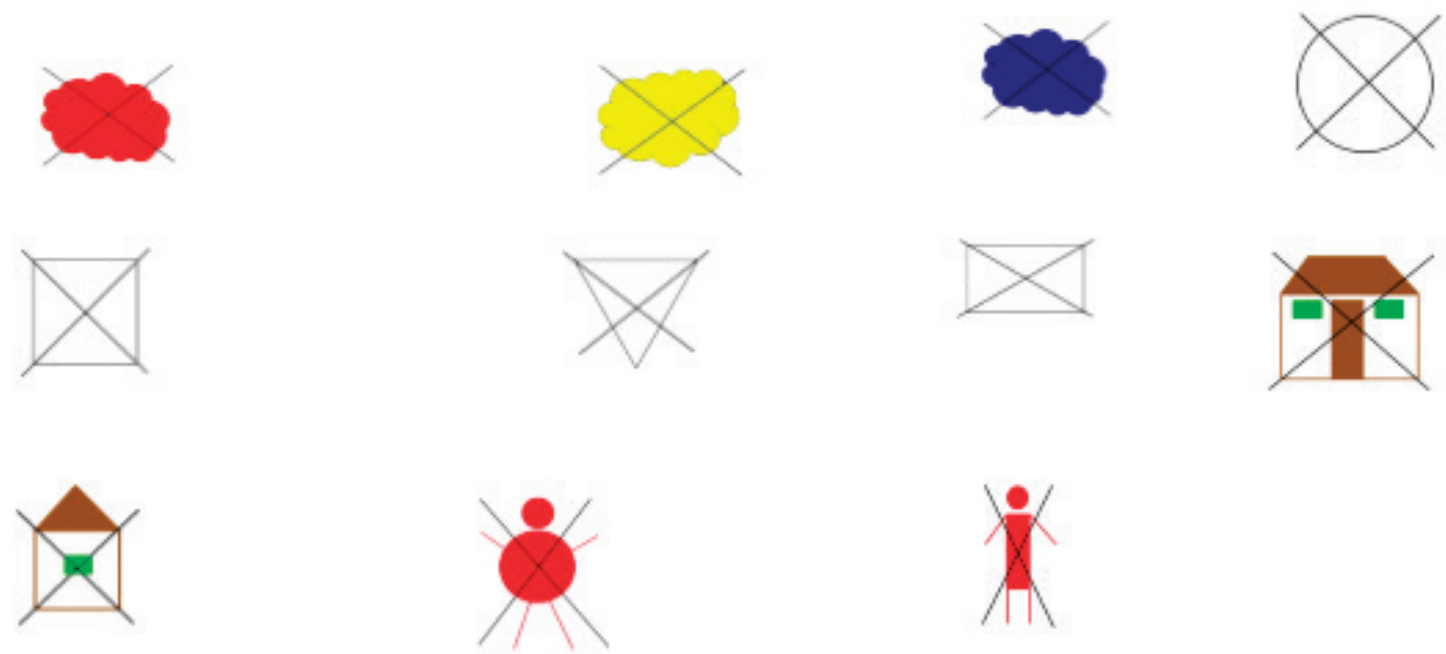

Таким образом, логические блоки Дьенеша дают возможность формировать в комплексе все логические операции мышления, в плане изучения математического содержания, это освоение понятий взаимосвязи изучаемого материала, а также структурные логические связи данного материала с другими темами элементарного предматематического блока.

Литература:

1. Ерофеева, Т.И. Использование игровых проблемно-практических ситуаций в обучении дошкольников элементарной математике // Дошкольное воспитание. - 1996. - № 2.

2. Е.Н. Носова, Р.Л. Непомнящая. Логика и математика для дошкольников: Методическое пособие /Авт. сост. е.Н.Носова, Р. Л. Непомнящая / (Библиотека программы «Детство). - Спб: «Акцидент», 1977. - 79 с.

3. М. Фидлер. Математика уже в детском саду: Пособие для воспитателей дет. сада /Пер. с польск. О.А. Павлович. - М.: Просвещение, 1981. - 159 с.

4. М. Фидлер. Математика уже в детском саду: Пособие для воспитателей дет. сада /Пер. с польск. О.А. Павлович. - М.: Просвещение, 1981.- с. 76-83 


\title{
Метод моделирования в реализации преемственности воспитания нравственных качеств личности в дошкольном и общеобразовательном учреждениях
}

\author{
Искакова Марина Александровна, студент
}

Омский государственный педагогический университет

$\mathrm{B}$ современных условиях выполнение задач воспитания нравственных качеств личности может быть успешным при психологической установке воспитателя, учителя-предметника, классного руководителя на системный, деятельностный, личностный подходы к воспитанию, соответствующем уровне педагогической культуры педагога, родителей, использовании специального педагогического инструментария для диагностики сформированности нравственных качеств личности.

Чтобы не ошибиться в процессе воспитания нравственных качеств личности ребенка и школьника, очень важно отчетливо представлять прошлое, нынешнее и будущее состояние воспитательной системы, ее компоненты, внутрисистемные и внешние связи, процесс ее функционирования и развития. Такие представления можно сформировать с помощью метода моделирования.

Особенности и условия-использования моделирования рассмотрены в исследованиях В. Г. Афанасьева, В.А. Веникова, А.Н.. Кочергина, П. С. Краснощекова, Н. М. Мамедова, И. Б. Новика, А. И. Уемова, В.А. Штоффа.

Моделирование воспитательных систем изучали Л. И. Новикова, Н.Л. Селиванова, Е.Н. Степанов.

Под моделированием понимается, «метод опосредованного практического или теоретического оперирования объектом, при котором исследуется не сам объект, а используется вспомогательная искусственная или естественная система, находящаяся в определенном объективном соответствии с познаваемым объектом, способная замещать его на определенных этапах познания и дающая при ее исследовании в конечном счете информацию о самом моделируемом объекте».

Моделирование является универсальным методом познания, поэтому применяется практически во всех видах деятельности, а «его универсальность выражается, прежде всего в целесообразности, эффективности использования на всех стадиях процесса деятельности (стадии целеполагания, изучения объекта, выбора средств и образа действий; реализации намеченной; цели и оценки достигнутого результата)» [4].

Модель (франц; modele, от лат. modulus - мера; образец, норма), в логике и методологии, науки - аналог (схема; структура; знаковая; система) определенного фрагмента природной или социальной реальности, порождения человеческой культуры, концептуально-теоретического образования и т.п. - оригинала, модели. Этот аналог служит для хранения и расширения знания (информации) об оригинале, конструирования оригинала, преобразования или управления им.
Модель - «мысленно представленная или материально реализованная система, которая, отображая или воспроизводя объект исследования, способна заменить его так, что ее изучение дает нам новую информацию об объекте». Эти оценки применимы и к моделям на этапе преобразования тех или иных объектов.

Известно, что наиболее распространенными являются модель-образец и модель-заместитель. При этом модель-образец используется в ситуациях, когда объект реально существует в объективной действительности, она используется для изучения и преобразования его нормативных свойств. Модель-заместитель используется, как правило, в ситуациях, когда объект еще отсутствует в полном виде в объективной реальности, при этом модель используется в поисково-конструктивных целях. Данные модели могут обеспечивать полное или локальное подобие объекта. Все эти положения в полной мере относятся и к социально-педагогическим моделям.

В данном случае построение модели осуществляется в целях разработки организационно-педагогических условий преемственности воспитания нравственных качеств личности дошкольников и школьников, так как моделирование помогает систематизировать знания об изучаемом процессе, подсказывает пути их целостного описания, намечает связи между компонентами.

Разрабатывая модель преемственности воспитания нравственных качеств личности в дошкольном и общеобразовательном учреждениях, можно рассматривать ее как одно из возможных решений проблемы-преемственности разных ступеней образования.

Методологическими основами в построении модели преемственности воспитания нравственных качеств личности в дошкольном и общеобразовательном учреждениях являются такие подходы как системный, деятельностный, личностный.

Преемственность воспитания нравственных качеств личности в дошкольном и общеобразовательном учреждениях мы исследуем с позиции системного подхода, который предусматривает познание закономерностей и взаимообусловленности исследуемого процесса, обеспечивающих его целостность. В понимании системы мы разделяем точку зрения В.Г. Афанасьева, который определяет целостную систему как совокупность компонентов, взаимодействие которых порождает новые (интегрированные, системные) качества, не присущие ее образующим [1].

Ю.А. Кустов, проведя анализ работ философов по проблеме системного исследования (И.В. Блауберг, В.Н. Садовский, Э.Г. Юдин и др.), сделал вывод, что система представляется как множество взаимосвязанных 
элементов, образующих устойчивое единство и целостность, обладающее интегральными свойствами и закономерностями. Н.Е. Щуркова, изучая системный (целостный ) подход к воспитанию, предполагает, что процесс воспитания конструируется как система, порождаемая осознанной целью воспитания. Именно предполагаемый результат в своей природной субстанции требует системы и задает структуру соответствующей системы.

Таким образом, под системой понимают взаимосвязанное единство отдельных частей, образующее новое (по сравнению с каждой из частей, их совокупностью) качество, которому присущи свои специфические свойства. Применение системного подхода открывает возможность систематического, организованного и упорядоченного рассмотрения структуры элементов целого, его внутренних и внешних связей, а также процесса, явления, в развитии.

Использование системного подхода в построении модели преемственности воспитания нравственных качестве личности в дошкольном и общеобразовательном учреждениях, предполагает четкую постановку проблемы, определение средств ее решения, а также способствует улучшению организации данного исследования, помогает глубже проникнуть в суть исследуемой проблемы.

Применив системный подход к разработке данной проблемы, было выяснено, что системообразующим фактором нравственного воспитания является деятельность, это делает процесс целостным.

Таким образом, для осуществления системного подхода при реализации модели преемственности воспитания нравственных качеств личности в дошкольном и общеобразовательном учреждениях необходимо учитывать характерные особенности ведущей деятельности дошкольников и школьников. Деятельностный подход - один из основных в изучении и организации педагогического процесса, так как указывает на единственно возможный путь формирования личности - на активную деятельность самого ребенка.

Учитывая вышесказанное, необходимо применять, деятельностный подход при осуществлении преемственности воспитания нравственных качеств» личности в дошкольном и общеобразовательном учреждениях. Данный подход обязывает рассматривать любую деятельность как совместную - продуктивную деятельность педагога и ребенка на основе сотрудничества.

Личностный подход в воспитании нравственных качеств личности (Е.В. Бондаревская, В.А. Қараковский) требует признания уникальности личности, ее нравственной свободы, права на уважение, учитывает возрастные особенности детей, включает в себя признание ребенка активным субъектом воспитательного процесса $[2,3]$.

Учитывая перечисленные подходы в воспитании, можно сконструировать модель преемственности воспитания нравственных качеств личности в дошкольном и общеобразовательном учреждениях. Преемственность воспитания нравственных качеств личности в дошкольном и общеоб- разовательном учреждениях рассматривается как сложная система состоящая из взаимосвязанных элементов. Ими являются цель, задачи, принципы, содержание, формы, методы, средства, результат. Модель преемственности воспитания нравственных качеств личности в дошкольном и общеобразовательном учреждениях создавалась с помощью компонентного механизма моделирования.

В модели выделены целевой, содержательный, структурный, технологический, организационный и результативный компоненты.

Основу модели составляют организационно-педагогические условия реализации преемственности воспитания нравственных качеств личности в дошкольном и общеобразовательном учреждениях:

- готовность педагога к реализации комплексной программы воспитания нравственных качеств личности детей и учащихся;

- органичное включение разработанной программы в учебную и внеучебную деятельность взаимосвязь (содержательная и технологическая) всех ступеней образования;

- ДОУ, начальные классы в воспитании нравственных качеств личности;

- организация совместной деятельности педагогов, родителей и детей.

Целевой компонент модели позволяет предопределить ожидаемый результат и скоординировать деятельность воспитателей, учителей начальных классов, классных руководителей, учителей-предметников и включает в себя:

- цели и задачи воспитания нравственных качеств личности;

- принципы преемственности, координации, интеграции, диатропичности.

Результат: повышение эффективности воспитания нравственных качеств личности

Принцип преемственности в процессе воспитания нравственных качеств личности предполагает осуществление связи между содержанием, формами, методами и средствами воспитания нравственных качеств личности, когда новое, сменяя старое, сохраняет в себе его элементы. Этот принцип осуществляет вертикальную взаимосвязь, при этом сохраняя горизонтальное взаимодействие. Преемственность, с одной стороны, аккумулирует систему воспитания нравственных качеств личности, с другой стороны, обеспечивает ее развитие, преобразование. Реализация принципа преемственности возможна лишь тогда, когда действия всех субъектов воспитательной деятельности взаимосвязаны, взаимообусловлены во времени и пространстве.

Принцип интеграции обеспечивает укрепление связей отдельных функций, методов воспитания нравственных качеств личности на разных этапах, способствует их универсализации и гармонизации, объединяет все элементы и создает объективные возможности для развития системы, позволяет обеспечить целостность происходящих процессов. 
Принцип координации создает условия для согласования последовательных действий всех участников воспитательного процесса в решении проблемы, предполагает логичность и последовательность этапов, совмещение и согласование интересов при достижении цели. Главным в реализации данного принципа является обеспечение синхронизации индивидуальных действий, слаженного педагогического взаимодействия в воспитании нравственных качеств личности.

Принцип диатропичности в процессе воспитания нравственных качеств личности обусловлен разнообразием со держания, средств, форм, методов процесса воспитания, а также различной степени выраженности потребностей и мотивов его участников, уровня подготовленности, психологических особенностей субъектов деятельности.

Содержательный компонент модели преемственности воспитания нравственных качеств личности в дошкольном и общеобразовательном учреждениях имеет полиструктурный характер. Содержательный компонент выполняет следующие функции: ориентирующую (обучение ребенка пониманию смысла человеческого существования); субъектно-личностную (ценность существования себя и других людей); операциональную (осознание своей роли, понимание и осознание исторического прошлого и будущего); нравственную (возрождение нравственных общечеловеческих ценностей, норм и правил).

Литература:

1. Афанасьев, В. Г. О системном подходе к воспитанию [Текст] / В. Г. Афанасьев //Советская педагогика. 1991. - № 2. - с. 77-81.

2. Бондаревская, Е.В. Нравственное воспитание учащихся в условиях реализации школьной, реформы [Текст]: учебное пособие / Е. В. Бондаревская. - Ростов н/Д: РГПИ, 1986-120 с.

3. Бондаревская, Е. В. Ценностные основания личностно ориентированного воспитания [Текст] / Е. В. Бондаревская // Педагогика. - 1995. - № 4. - c. 29-35.

4. Веников, В. А. О моделировании [Текст]/ В.А. Веников. - М: Знание, 1974. — 64 с.

\section{Роль оценочных способностей в формировании и развитии личности обучающегося}

Каргина Елена Михайловна, кандидат педагогических наук, доцент

Пензенский государственный университет архитектуры и строительства

Статья посвящена рассмотрению роли оценочных способностей в формировании и развитии личности обучающегося. Оченочные способности обучающегося анализируются во взаимосвязи с другими психологическими функциями и характеристиками личности. Отмечается значение референтных групп и первичных социальных объединений в формировании оценочных способностей личности. Подчеркивается влияние оценочных способностей на мотивацию профессионального самоопределения обучающегося.

Ключевые слова: оценочные способности, формирование и развитие личности, обучающиеся, психологические функции и характеристики личности, мотивация профессионального самоопределения.

$\mathrm{O}$ ценочные способности играют значимую роль в структуре личности, в ее формировании и развитии. Оценочные способности оказывают влияние на мышление, память, на становление характера, совершенствование других способностей, умений и навыков, в первую очередь навыков человеческого общения. Они влияют на мотивационную сферу и самосознание индивида, на профессиональное самоопределение [1, с. 53], на социальные и эмоциональные установки, на отношения человека к себе и другим людям. Системно проанализировать процесс формирования и развития оценочных способностей можно только с учетом характеристик параллельно развивающихся познавательных процессов, мотиваций, эмоций и других характеристик, объеди- ненных в современных психологических представлениях в понятии «личность».

В качестве первоисточников самооценок и оценок других людей в период юности могут выступать мнение родителей, суждения педагогов, высказывания других, значимых для школьника взрослых людей, мнения друзей по школе, суждения, получаемые из произведений искусства и средств массовой информации, мнения, сложившиеся в собственном опыте. Все это может повлиять на суждения юношей и девушек о людях. Однако мнение, выражаемое человеком, не является простым повторением того, что сказано другими людьми или заимствовано из иных источников информации. Оно всегда является также продуктом собственных размышлений, сравнения 
человеком себя, своего поведения с личностными чертами и поступками других людей, с оценками, даваемыми другими людьми, со своими собственными идеалами.

Идеалы являются важным атрибутом самовоспитания. Этот процесс в период ранней юности весьма противоречив и динамичен, полон внутренних и внешних проблем. Для того, чтобы целенаправленное воспитание, организуемое семьей и школой, достигло своей цели, оно должно дополняться самовоспитанием. Очень важно, чтобы идеалы, включенные в систему педагогического и семейного воспитания, не противоречили друг другу.

Развитие личности ребенка - целостный процесс. Отдельные стороны личности, например оценочные способности, не могут развиваться независимо от остальных свойств и качеств личности. Так, трудно себе представить формирование характера человека без развития способностей, развитие способностей без представлений о психических процессах, а становление познавательных функций - без развития мотивационной сферы [2]. Все эти психологические функции и характеристики личности взаимосвязаны, и обособление одной из них неизбежно сказывается на развитии другой.

Особое место в управлении формированием оценочных способностей школьников отводится так называемым референтным группам и первичным социальным объединениям - группам и коллективам. Общение в группах сверстников, особенно одноклассников и одногруппников, чтение художественной литературы, посещение кино, театра и т.п. дают молодым людям богатый материал для размышлений, для разнообразных сравнительных оценок себя с другими людьми.

При осознании себя как личности, оценивании своих собственных действий и поступков большую пользу обучающимся оказывают данные самонаблюдения. Они, однако, не выступают в чистом виде, а опосредуются общественным опытом, знаниями, полученными как в прямом, личном, непосредственном общении со значимыми людьми в разнообразных группах, так и в косвенном общении через произведения литературы, науки и искусства. Интенсивность и широта круга общения способствуют приобретению такого опыта. Разумеется, речь должна идти не о стихийном, а о педагогически продуманном, целесообразно организованном общении. Дефицит общения одна из часто встречающихся причин отставания развития личности, в особенности оценочных способностей.

Познавая себя, обучающийся как бы «переносит»на себя другое лицо, сравнивает себя с ним, осознает свое сходство и непохожесть на другого, сопоставляет сходные и отличительные черты с идеалом, дает себе оценку и делает вывод о том, что достойно чувства удовлетворения, а что в его личности требует дальнейшего совершенствования.

Межличностный перенос оценок предполагает предварительное упрочение общей точки зрения на себя как на существо принципиально такого же рода, как и все остальные люди, но со своими специфическими особенностями, которые должны познаваться в сравнении.
Традиционно существующие цели и задачи обучения и воспитания необходимо дополнить специальной задачей развития у обучающихся оценочных способностей, включить и ее в практику преподавания различных дисциплин, в первую очередь предметов общественного цикла, в практику осуществления внеаудиторной работы.

В системе воспитания оценочных способностей очень важно обеспечить для обучающихся надежный «социальный контроль», который осуществляется не только педагогическим коллективом, но и самими обучающимися через коллективное мнение. Можно предположить, что между оценками, даваемыми человеком себе и окружающими, и особенностями коллективного мнения существует прямая зависимость. Окружающие обучающегося люди могут как положительно, так и отрицательно влиять на его оценки; это в равной степени касается педагогов, родителей и сверстников. К примеру, завышение или занижение не всегда объективными в своих отношениях к обучающемуся педагогами или родителями своих оценок может отрицательно сказаться на самооценке обучающегося, соответственно завышая или занижая ее. Это же неблагоприятно может повлиять на развитие его оценочных способностей, на характеристики, которые он сам будет давать окружающим людям, на взаимоотношения, складывающиеся с ними.

Существует определенная взаимосвязь между оцениванием обучающимися своей учебы, жизненного опыта, с одной стороны, и выбором будущей профессии, с другой.

Анализ результатов исследований Л.И. Мнацаканян [3] свидетельствует о том, что 26,8\% старшеклассников выбирают профессию, руководствуясь желанием приносить пользу обществу, они отличаются высокой целеустремленностью, самокритичностью, большой требовательностью к своим знаниям. Эти обучающиеся имеют полное представление о выбранной профессии, дают ее полную характеристику.

Самая большая группа обучающихся (40\%) связывает общественные и личностно-значимые мотивы выбора профессии.

Источником мотивации профессионального выбора двух данных групп обучающихся является подражание взрослым - педагогам, родителям, окружающим людям $[4$, с. 87$]$.

Выбор профессии у другой подгруппы обучающихся детерминирован честолюбивыми стремлениями. Они хотят стать известными, признанными, почетными людьми. Как правило, это способные обучающиеся, правильно представляющие себе выбранную профессию, ее общественную значимость. Они уверены в себе, отличаются высоким уровнем притязаний. Увлечение своей будущей профессией становится характерной особенностью досуга этих обучающихся. Они ходят в кружки, читают специальную литературу. Желание достигнуть вершин профессионального успеха у этих обучающихся следует рассматривать как положительное явление, так как престижные устремления у них сочетаются с выбором полезных, социально востре- 
бованных профессий. Обучающимся данной группы присущи твердая воля, самоанализ, самокритичность.

Немалую группу среди старшеклассников составляют не устоявшиеся или не определившиеся в выборе профессии. Они поступают в вуз не потому, что им нравится то или иное направление подготовки, а лишь для того, чтобы не остаться без высшего образования. Ко всем профессиям они относятся одинаково положительно, но без особого интереса.

И, наконец, особую группу составляют старшеклассники, у которых доминируют индивидуалистические мотивы. Эти школьники мало думают об образовании. Большое влияние на формирование личности обучающихся этой группы оказывает микросреда (семья, круг общения). Старшеклассники стихийно ориентируются на окружающих, часто не предвидя возможных отрицательных последствий. В этом сказывается недостаточное развитие оценочных способностей, неумение ориентироваться на настоящие ценности, видеть и отличать моральное от аморального, нравственное от безнравственного.

Выявляя такого рода умонастроения, отклоняющиеся от принятых моральных норм, родителям, педагогам необходимо задуматься, откуда это идет, где их истоки и использовать все средства педагогического воздействия, чтобы исключить подобные интересы и «идеалы». Этого можно добиться, вызывая доверие к себе, отсекая негативное и подкрепляя положительное фактами из жизни.

Обучающиеся, для которых характерны приспособленческие мотивы в выборе профессии, руководствуются исключительно прагматическими соображениями, приспосабливаются к обстоятельствам, идут по наиболее легкому и выгодному пути, думают найти в жизни спо- койное, удобное место, маскируя свои взгляды, скрывая от других жизненные планы, цели и стремления.

В особую группу следует выделить старшеклассников с безразличным отношением к профессиональному самоопределению. Это безразличие, по всей вероятности, является результатом отсутствия учебных интересов. Обучающиеся данной группы считают, что любая профессия может быть и хорошей, и плохой. У них отсутствует избирательное отношение к профессиям, и профессиональный выбор не выступает для них как значимая и актуальная жизненная проблема. Под влиянием взрослых, сверстников они могут выбрать любой вуз и учиться на любом факультете без внутреннего убеждения и без конкретной внутренней мотивации [5].

Безразличное отношение к будущей профессии сказывается на отношении старшеклассников к учебе в целом или же к определенным предметам. Их значимость для общего развития личности и будущей профессиональной деятельности при этом переоценивается.

Таким образом, рассматривая проблему значимости оценочных способностей в формировании и развитии личности обучающегося, следует подчеркнуть, что, чем более развита оценочная способность, тем выше мотивация профессионального самоопределения [6]. Между знаниями, умениями и оценочными способностями существует прямая зависимость. Тесная связь существует и между самооценкой обучающихся и способностью к выбору определенной профессии. Выбор профессии обучающимися является не только средством и способом развития оценочных способностей, но выступает и как показатель или выражение соответствующих способностей.

Литература:

1. Климов, Е.А. Психология профессионального самоопределения. - М., 2004.

2. Қаргина, Е.М. Формирование профессиональной мотивации будущих специалистов (на примере ассоциации «Университетский учебный комплекс»): автореф. дис. ... канд. пед. наук. - Пенза, 2004.

3. Мнацаканян, Л.И. Личность и оценочные способности старшеклассников: Книга для учителя. - М.: Просвещение, 1991. - 191 с. - С.40.

4. Ильин, Е. П. Мотивация и мотивы. - СПб.: Питер. $-2002 .-512$ с.: ил. - (Серия «Мастера психологии»).

5. Қаргина, Е. М. Мотивация обучения в вузе // Современные научные исследования и инновации. - 2014. № 6-3(38). - c. 5 .

6. Қаргина, Е.М. Особенности профессионального самоопределения специалиста в современных социально-экономических условиях // Современные научные исследования и инновации. - 2014. - № 3 (35). - c. 43.

\section{Генезис методики преподавания иностранных языков как науки}

Каргина Елена Михайловна, кандидат педагогических наук, доцент

Пензенский государственный университет архитектуры и строительства

В статье анализируется процесс формирования и развития методики преподавания иностранных языков как науки. Рассматриваются вопросы обогащения системь методических понятий и совершенствования исследовательского аппарата рассматриваемой отрасли науки. Представлень новые цели методических исследований. 
Ключевые слова: генезис, формирование, развитие, методика преподавания, иностранный язык, наука, методические понятия, исследовательский аппарат.

$\mathrm{C}$ тановление каждой науки предполагает в качестве необходимых условий не только выделение своего предмета исследования и создание своего исследовательского аппарата (приемов и методов исследования), но и формирование своей системы научных понятий и соответствующих терминов.

Предмет методики как науки четко определен: методика - «наука о законах и правилах обучения какой-либо дисциплине» [1]. Методика обучения иностранным языкам - наука, изучающая «законы и правила» обучения языку и овладения иностранным языком, точнее овладения речевой деятельностью на том или ином иностранном языке. Развивая это определение, следует уточнить, что, отправляясь от своих законов, закономерностей и правил, методика как наука исследует и разрабатывает не любые возможные методы и приемы обучения, а только те, которые обеспечивают овладение речью на иностранном языке наиболее экономичным и эффективным в отношении достижения цели путем. Предмет методики как науки был определен достаточно точно со времени ее зарождения. В последующие десятилетия содержание его постоянно обогащалось.

В последние десятилетия значительно расширился и исследовательский аппарат методики [2]. Так, шире стало использоваться инструментальное исследование важных для обучения параметров речевых процессов, уровней обученности. Нормативным стало применение в методических исследованиях принципов моделирования речевых процессов и системы соответствующих приемов овладения речью. Широко используются методы статистического исследования, вероятностного прогнозирования и т.д.

Значительные изменения произошли и в развитии методических понятий, в частности введено и разработано фундаментальное понятие учебного минимума (И. В. Рахманов), принципы его отбора и связанные с этим проблемы и положения. Фундаментальным является введенное понятие дифференцированной (рецептивно-репродуктивной), направленной методики обучения языкам. Содержание научной методики обогатилось понятием потенциального словаря обучающихся, описанием понятия выводимости лексики. Разработаны четкие определения видов чтения. Внедрено понятие функциональной, в том числе пассивной грамматики чтения и многие другие [3].

Обогащение системы методических понятий происходит как за счет уточнения и частичного преобразования уже существующих понятий, так и за счет модификации понятий, заимствованных из других наук. Последние составляют значительную часть системы методических понятий. Факт заимствования методикой понятий из других наук объясняется пограничным характером методики как науки по отношению к базовым для нее наукам. Заимствуя первоначально понятия, лежащие на стыке наук, методика рассматривает их в ракурсе своих целей и задач: с одной стороны, дополняя эти понятия характеристиками, существенными для процессов обучения, а с другой - исключая из содержания заимствованных понятий характеристики, не релевантные для методики.

Такой подход к формированию научных понятий следует из самой динамики познания. Один и тот же объект в зависимости от того, в каком отношении он используется, обнаруживает различные признаки, комплекс которых каждый раз может быть описан в ином виде. Основанием для выделения существенных признаков является цель, практическое отношение человека к предмету.

Новые цели методических исследований открывают новые ракурсы рассмотрения объектов, заставляют вскрывать их новые свойства и отношения, ведут к изменению в объеме признаков первоначальных понятий, что, в конечном счете, позволяет говорить о формировании нового понятия, понятия собственно методического.

В силу того, что процесс переформирования признаков понятия обычно продлен во времени, пока еще не произошла окончательная дифференциация и выделение нового научного понятия, возникает возможность смешения исходного и формируемого понятий, опасность умножения термина. Так, например, в значительной степени из-за недостаточной дифференцированности исходных (психологических) и новых (методических) терминов «пассивный», «рецептивный»- «активный», «репродуктивный» среди некоторых психологов возникло непонимание, вызвавшее дискуссию 1952-53 годов [4]. Введенные в заблуждение отсутствием, в их понимании, должного разграничения сходных терминов, они не смогли сразу увидеть то, что в отличие от привычного для них термина, описывающего недеятельное состояние субъекта («пассивный»), в методике появился новый термин, за которым стоит новое понятие, отличающееся своим объемом признаков: «пассивный» («рецептивный») - относящийся к восприятию и переработке речевой посылки, что предполагает активность реципиента. Последующее бурное развитие теории информации и кибернетических аспектов лингвистики убедительно подтвердило целесообразность использования в методике новых понятий и терминов, соотносимых с деятельностью «отправителя» и «получателя» информации. С течением времени правомерность этих методических понятий была признана широкими кругами и методистов, и психологов. Они прочно вошли в научный аппарат методики, в пособия, терминологические словари и монографии, издаваемые и в России и за рубежом.

Аналогичным образом за счет переноса понятия из терминологического аппарата психофизиологии и последующей модификации его содержания появился методический термин «дифференцировка», который означал уже 
не «различение условных раздражителей», что в физиологии происходит без осмысления составляющих, а различение языковых явлений при их первичном усвоении на основе аналитического выделения их признаков.

Аналогичный путь прошел в своем становлении термин «вербализация», первоначально заимствованный из психологии, где он означал «словесное выражение мысли». В приложении к методике обучения иностранным языкам он был модифицирован И. В. Қарповым [5] и стал означать воспроизведение формы иностранного слова без соотнесения ее со смыслом. По мере уточнения этого методического понятия появились его разновидности: вербализация как воспроизведение и восприятие формы слова без ее соотнесения со значением, и вербализация как связывание формы слова только с его значением (без соотнесения со смыслом) [6].

Преобразование заимствованных понятий в методические путем выделения в предмете признаков, существенных для методики, является одним из путей пополнения системы ее научных понятий. Задачи дальнейшего совершенствования методической терминологии и обогащения ее новыми научными понятиями указывают на необходимость определения специфики выделения признаков методических понятий, в частности, при заимствовании исходных понятий из родственных и смежных наук.

Явления и понятия, относящиеся к человеку и к овладению им различными формами деятельности, в том числе и понятия, связанные с языком и мышлением, можно рассматривать в различных ракурсах. В плане исторического становления, охватывающего десятки тысяч лет, то есть в филогенезе они обнаруживают одни характеристики. Совершенно иные характеристики обнаруживаются при анализе языка и мышления в плане развития и становления индивидуума, то есть в онтогенезе.

Важно указать на отличие и от филогенеза и от онтогенеза процессов актогенеза - процессов актуального развития и протекания конкретного действия [7]. Не все признаки понятий, описывающих процессы филогенеза и онтогенеза, сохраняются в качестве существенных при рассмотрении фактов актогенеза.

Положение о недопустимости смешения понятий филогенеза, онтогенеза и актогенеза не всегда очевидно при описании процессов методики обучения иностранным языкам, что часто является причиной недоразумений в употреблении терминов и оперировании понятиями. Их различие подтверждается тем, что если лингвистические факты филогенеза и онтогенеза соотносимы с «языковой системой»и «языковым материалом», как они описаны Л.В. Щербой [8], то факты актогенеза соотносимы с «речевой деятельностью», которая актуализуется «в условиях конкретной обстановки данного момента».
Специфику методических понятий, относящихся к обучению и овладению языком, составляет в первую очередь то, что они должны отражать факты актогенеза, факты «речевой деятельности», а не свойства «языкового материала» или «языковой системы», как это случается при непосредственном заимствовании понятий и положений из смежных с методикой наук [9].

Рассматривая вопросы формирования понятийного аппарата методики, следует отметить, что недопустимо, в частности, произвольное перенесение философских и лингвистических понятий на объекты методики. Известно положение философии о том, что «язык является непосредственной действительностью мысли». Применяя это положение непосредственно к фактам языковой практики, некоторые методисты сначала произвольно обращают это суждение в утверждение «единственной формой существования мысли является язык», а затем делают вывод, что мышление осуществляется исключительно средствами натурального языка, поскольку «оголенные мысли», «мысли без языка» не существуют. Они неоправданно приходят к методическим выводам о том, что обучение иностранному языку должно представлять собой «обучение перекодированию с родного языка на иностранный».

Описывая взаимосвязь понятий «язык» и «мышление», следует четко разграничить план методологических, философских понятий, понятий категориальных, а поэтому охватывающих весь филогенез, и понятий методических, соотносимых с конкретными актами речевой деятельности.

Для философии важны следующие признаки и связи понятий «язык» и «мышление»:

1. Человека как такового отличают высшие формы абстрактного мышления, к которым он пришел на основе и при помощи языка, выступающего средством абстрагирования (филогенез), мышление как таковое, абстрактное мышление без языка невозможно. (Утверждение категориальное).

2. Мышление человека социально, характер его определяется многовековой практикой коллектива (филогенез); живя в обществе, будучи его членом, человек мыслит, чтобы сделать результаты мышления достоянием других, что невозможно без использования такого универсального средства передачи мысли, как язык. (Утверждение категориальное).

3. Наивысшей формой отражения действительности является сознание. В языке запечатлен общественно-исторический опыт и общественное сознание (филогенез). Язык же является практическим сознанием. (Утверждение категориальное).

Таким образом, при категориальном рассмотрении связей языка и мышления следует правомерно указать на их неразрывное единство.

Литература:

1. Рахманов, И. В. Очерк по истории методики преподавания новых западно-европейских иностранных языков. M., 1947.- c. 7 . 
2. Каргина, Е. М. Повышение значимости иностранного языка как составной части вузовской программы // Культура и образование. - 2014. - № 7 (11). - с. 12.

3. Қаргина, Е.М. Дидактические и психологические факторы обучения иностранному языку в техническом вузе // Гуманитарные научные исследования. - 2014. — № 9 (37). — c. 60-63.

4. Рахманов, И. В. Рецептивное и репродуктивное усвоение иностранного языка в средней школе // Иностранные языки в школе. - 1952. - № 4; Беляев Б. В. О психологических основах методики рецептивного и репродуктивного усвоения иностранных языков // Иностранные языки в школе. - 1954. — № 1 .

5. Карпов, И. В. Психологическая характеристика процессов понимания и перевода учащимися иностранных текстов. В кн.: Вопросы теории и методики учебного перевода. - M., 1950.

6. Очерки методики обучения чтению на иностранных языках. Под ред. И. М. Бермана, В.А. Бухбиндера. - К., 1977. - с. $31-32$.

7. Берман, И. М. Актогенез речи и формирование методики как науки // иностранные языки в высшей школе.1981. - № 16. - c. 4-18.

8. Щерба, Л. В. О трояком аспекте языковых явлений и об эксперименте в языкознании. В сборнике «Языковая система и речевая деятельность». - Л., 1974. - с. 24.

9. Каргина, Е. М. Анализ проблемы различий иноязычных речевых и языковых навыков в историко-методологическом контексте // Гуманитарные научные исследования. - 2014. - № 11 (39). — с. 94-97.

\title{
Сущность интернационального воспитания в контексте всестороннего развития пионеров (60-80-гг. XX в.)
}

\author{
Карташова Юлия Александровна, аспирант \\ Донбасский государственный педагогический университет (г. Славянск, Украина)
}

В статье рассматриваются содержание и основные задачи интернационального воспитания подрастающего поколения в 60-80-е гг. ХХ в. Подчеркивается, что интернациональное воспитание было в центре внимания пионерской организации. Его задачи решались в контексте всестороннего развития подростков и в связи с другими направлениями воспитания: умственным, физическим, нравственным, трудовым, патриотическим.

$\Gamma$ лавным содержанием воспитания подрастающего поколения в 60-80-е гг. XX в. было коммунистическое воспитание, которое предусматривало всестороннее гармоническое развитие личности и включало такие направления, как идейно-политическое, нравственное, трудовое, эстетическое, физическое воспитание. Труды педагогов тех времен (И. Верба, В. Заслуженюк, Г. Иващенко, К. Радина, З. Ходоровская, Б. Ширвиндт и др.) свидетельствуют о том, что в этой системе видное место занимало интернациональное воспитание, которое было связано со всеми составляющими и использовало их формы и методы $[1 ; 2]$.

В педагогической литературе рассматриваемого периода интернациональное воспитание (воспитание в духе любви к Родине, к народам, борющимся за свободу, солидарности) было включено в содержание идейно-политического воспитания и осуществлялось в комплексе с трудовым и нравственным воспитанием [3, с. 8].

Анализ литературных источников показал, что в 6080-е годы XX в. интернациональному воспитанию подрастающего поколения уделялось много внимания. Это было обусловлено теми общественно-политическими условиями, которые сложились в СССР, и международной

политикой, которую осуществляла Коммунистическая партия. «Необходимость интернационального воспитания, - отмечал А. Жумаканов, - определялась сущностью советского государства и политикой Коммунистической партии, направленной на укрепление международной пролетарской солидарности, братских связей с трудящимися всех стран» [2, с. 28].

Дальнейшее углубление единства, сплоченности и всестороннего сотрудничества стран социализма на принципах равноправия, взаимопомощи и уважения, рост международного авторитета СССР, который обеспечивался внутренней и внешней политикой ҚПСС, ориентированной на союз, сотрудничество и дружбу с другими социалистическими странами, сплочение международного коммунистического и рабочего движения, размах антиимпериалистической и национально-освободительной борьбы, возникновение новых национальных государств - все это объективно способствовало усилению внимания к интернациональному воспитанию подрастающего поколения. Об этом говорилось во многих документа партии и правительства: материалах съездов (XXII XXVII), постановлениях, решениях партийных пленумов 
(июльский 1972 г., майский и сентябрьский 1974 г. пленумы ЦК Компартии Украины; июньский 1983 г., февральский 1988 г. пленумы ЦК КПСС). В частности, в постановлении ЦК КПСС «О подготовке к 50-летию образования Союза Советских Социалистических Республик» была поставлена задача «воспитания подрастающего поколения в духе коммунистической идейности, преданности нашей Советской Родине, нерушимой дружбе народов, социалистического интернационализма» [4].

Таким образом, интернациональное воспитание выступало как важный фактор, который создавал основу для сближения и сотрудничества народов всех стран социализма, укрепления их дружбы и рассматривалось как одно из условий строительства нового общества [5, с. 6-7].

С одной стороны, интернациональное воспитание было составляющей коммунистического воспитания, с другой, это было система, которая имела свои компоненты: цель и задачи, содержание, организацию и методику. В то же время она взаимодействовала с другими сторонами коммунистического воспитания, «образуя целостный процесс формирования личности социалистического типа» [1, с. 29].

Так, в процессе умственного воспитания, в первую очередь во время изучения учебных предметов, у учащихся формировали интернационалистское мировоззрение, вооружали их необходимыми знаниями о развитии общества и классовой борьбе, о национальном вопросе и дальнейшем развитии наций, о межнациональных отношениях СССР, об общности путей революционной борьбы всех народов и закономерностях коммунистического строительства в странах социалистического содружества. В свою очередь, интернационалистские идеи и чувства, социальный опыт укрепляли знания школьника, обогащали его интеллект. Таким образом, наполняя процесс обучения интернационалистским содержанием, школа не только развивала учащихся умственно, но и вводила, как писал В. Сухомлинский, «ребенка в сложный мир человеческих отношений» [6, с.83].

Нравственное воспитание наполняло деятельность школьников особенным характером отношений к окружающему миру и людям, формировало у детей сознание, чувства, поведение, а также такие важные для патриота-интернационалиста качества, как гуманизм, толерантность, уважение к другим людям, солидарность, сочувствие и др. Трудовое воспитание выдвигало задачу воспитания любви к труду и людям труда. Труд во имя общих интересов, братская взаимопомощь и трудовые традиции народов СССР социалистическое соревнование были важными источниками как трудового, так и интернационального воспитания. В совместном труде у детей вырабатывалось чувство солидарности и взаимопомощи.

В единстве с эстетическим воспитанием интернациональное воспитание развивало у школьников чувство прекрасного, в том числе и в его национальном проявлении, вооружало их идейными критериями понимания искусства, учило распознавать, критически оценивать чужие взгляды, вкусы и в то же время уважать прогрессивные традиции в искусстве, литературе, быте других наций и народностей, стремиться изучать и правильно воспринимать достижения мировой культуры.

В единстве с военно-патриотическим и физическим воспитанием интернациональное воспитание формировало у школьников любовь к Родине, волю, настойчивость в достижении целей, готовило молодежь к труду и защите Отчизны. Много форм и методов военно-патриотического и физического воспитания способствовали укреплению интернациональной дружбы детей. Так, участие во всесоюзных спартакиадах и международных соревнованиях укрепляло дружбу детей разных народов СССР, советских школьников с детьми из других социалистических стран, давало возможность общаться детям разных национальностей. Спорт был важным способом в борьбе за мир, за укрепление международного детского и молодежного демократического движения.

Интернациональное воспитание было тесно связано с воспитанием чувства коллективизма. Более того, интернационализм вырастал из коллективизма: сначала школьник осознавал интересы сравнительно небольшого коллектива, а потом, с развитием его связей с окружающим миром, расширялся и круг его взаимоотношений с разными коллективами. «Наш воспитанник, - писал А. Макаренко, - кем бы он ни был, никогда не может выступать в жизни как носитель личностного совершенства, только как добрый или честный человек. Он всегда должен выступать, прежде всего, как член своего коллектива, как член общества, который отвечает за поступки не только свои, но и своих товарищей» [7, с. 49]. На основе чувства коллективизма происходило развитие чувства интернационализма уже на высшем уровне становления личности школьника [1, с. 30-34].

Особенно тесной была связь интернационального воспитания с патриотическим. Большинство педагогов (И. Вовканич, В. Заслуженюк, Б. Кобзарь, В. Опаленик, В. Панибудьласка, Н. Терновая, В. Фарфоровский) ставило задачу воспитания патриотов-интернационалистов. Так, В. Заслуженюк считал интернационализм и патриотизм ведущими чертами всесторонне развитой личности $[8$, c. 8]. О. Опаленик подчеркивала, что воспитание патриотизма и интернационализма имело общую идеологическую и моральную основу. В их содержании она выделяет два аспекта: идейно-политический (формирование идейной убежденности, преданности делу коммунизма, любви к Родине и странам социалистического содружества) и нравственно-деятельный (воспитание чувства долга, чести, гуманности, непримиримости к недостаткам, готовности стать на защиту Родины и др.) [9, с. 38].

По мнению В. Опаленик, «интернациональное воспитание подрастающего поколения обогащает патриотические стремления и чувства, расширяет и углубляет знания школьников о роли международного объединения трудящихся в борьбе за мир, против капитализма и эксплуатации, формирует готовность отстаивать дело мира, придерживаться братских отношений между народами» [10, с. 50]. Педагоги подчеркивали, что в условиях многона- 
ционального государства, каким был СССР, воспитание патриотов и интернационалистов должно выступать как единый процесс.

Таким образом, интернациональное воспитание было частью целого, в состав которого оно входило, и осуществлялось в тесной связи со всеми другими направлениями коммунистического воспитания: умственным, нравственным, трудовым, эстетическим, физическим, а также коллективистским воспитанием молодежи. Взаимосвязь интернационального воспитания детей и подростков с другими составляющими коммунистического воспитания обеспечивалось единством задач, методов и форм воспитания.

Педагоги (В Заслуженюк, В. Опаленик, В. Панибудьласка и др.) рассматривали интернациональное воспитание школьников также как часть учебно -воспитательного процесса - оно осуществлялось во время изучения основ наук, в процессе внеклассной и внешкольной воспитательной работы, в ходе деятельности комсомольской и пионерской организаций, в процессе совместной работы школы, семьи, общественных организаций, производственных коллективов, объединений и советов ветеранов партии, комсомола, Великой Отечественной войны и труда. В частности, В. Заслуженюк отмечал, что как целостный педагогический процесс интернациональное воспитание представляло собой «запланированную систему воздействий на личность, в результате которых школьник усваивает идеи, принципы, традиции дружбы народов как общественно ценные и руководствуется этими принципами в своей жизни» [1, с. 41-42]. Оно предусматривало «целенаправленное и систематическое воздействие на сознание, чувства, волю с целью превращения соответствующих идей и принципов в глубокие убеждения, нормы поведения и деятельности советской молодежи» [8].

Анализ литературных источников позволил сделать вывод о том, что интернациональное воспитание подростков имело своей целью:

— расширить и углубить знания учащихся о роли международного объедине 1 ния трудящихся в борьбе за мир, сформировать готовность отстаивать дело мира, придерживаться правил братских отношений между народами [9, с. 38];

- формировать интернационалистские убеждения личности, которые определяли всю структуру ее ценностных ориентаций, установок и чувств, побуждали и направляли ее общественно-политическую, трудовую и познавательную активность [11, с. 17];

- выработать в учащихся соответствующее поведение, которое проявлялось в соблюдении принципа равенства, уважения достоинства людей всех наций, во внимательности и доброжелательности к представителям других национальностей, к их традициям, обычаям и языку [8, с. 10];

- формировать у подростков интернационалистические потребности, интересы, цели, социальные чувства, эмоции, настроения, навыки и т. под. [12].

В основе интернационального воспитания лежало чувство интернационализма. Социалистический интернацио- нализм подразумевал братскую солидарность между трудящимися разных стран. Он проявлялся в таких принципах, как дружба, единство и сплоченность на основе марксизма-ленинизма, товарищеская взаимопомощь и поддержка; равноправие и равная ответственность при выполнении интернационального долга; единство патриотизма и интернационализма, национальных и интернациональных интересов; борьба с национализмом и шовинизмом; уважение национальных чувств и достоинства других народов [13].

А. Жумаканов утверждал, что интернационализм это глубокое нравственное чувство, которое было одним из регуляторов поведения и деятельности личности. Интернационалистские чувства, отмечал он, социальны по своему источнику, содержанию и способу проявления. В основе их лежали общественные отношения, и они сами выступали как элемент нравственных отношений. Чувство интернационализма начинали формироваться с раннего возраста. В процессе развития они ставали лишь более зрелыми и осознанными [2, с. 42-43].

Интернационалистские понятия развивались и формировались на основе стройной системы научных знаний, которые учащиеся приобретали в процессе обучения. Убеждения, которые определяли линию нравственного поведения, были предпосылкой для сознательного отношения к окружающей среде и активной деятельности, направленной на преобразование мира. Формирование интернационалистских убеждений было связано с общественной деятельностью, практикой людей [2, с. 46].

Конечным результатом интернационального воспитания было формирование единства чувств, убеждений, взглядов, т.е., по словам А. Жумаканова, всей совокупности общественно-психологической структуры, которая определяла поведение личности [2, с. 47].

А. Жумаканов выделял 3 этапа интернационального воспитания. На I этапе происходило понимание и усвоение сущности и основных признаков социалистического интернационализма. Эта задача решалась благодаря организации этического просвещения в процессе обучения и во внеклассной работе. Школьникам разъясняли или показывали на практике значение интернационалистских чувств и качеств в жизни человека и государства, рассказывали, как эти качества должны проявляться в поведении. При этом добивались, чтобы усвоение детьми этих знаний, представлений, понятий опирались на эмоции и чувства. Тогда ребенок не просто понимал и осмысливал то, о чем ему гово рили, что внушали, но и чувствовал, переживал это, у него возникало определенное, как правило, положительное, отношение к тому качеству, которое хотели у него воспитать.

На II этапе нужно было пробудить желание и стремление к интернационалистской деятельности. Возникновение у детей эмоциональных переживаний и позитивного отношения к правилам и нормам интернационалистского поведения определяло поступки, ставало мотивом поведения, основой нравственных убеждений. А убеждения, под которыми подразумевались твердые, основанные на мировоззрении, моральных принципах и жизненном 
опыте взгляды, определяли жизненную позицию, служили руководством в делах и поведении. Воспитание и формирование убеждений - сложный и длительный процесс. Тут необходима была организация деятельности, наличие собственного опыта интернационалистского поведения.

Третий этап - организация практической деятельности школьников интернационального характера. Формирование и развитие личности вообще и этих качеств, в частности, происходило эффективнее, если воспитание было связано с общественно-активной деятельностью школьников, их посильным участием в коммунистическом строительстве. Практический опыт и упражнение в интернационалистском поведении позволяли сформировать убеждения, а также переводили нравственные поступки и действия в навыки, в норму повседневного поведения [2, с. 40-41].

Таким образом, интернациональное воспитание подростков представляло собой научно обоснованную систему деятельности, организованной и направленной на обеспечение глубокого усвоения ими идей и принципов социалистического интернационализма, на превращение их на глубокие убеждения и норму поведения [13, с. 3-4].

В воспитании подрастающего поколения большую роль играла пионерская организация. Следует отметить, что в теории коммунистического воспитания не было ни одного вопроса, который не был связан с её деятельностью. Среди разнообразных направлений содержания пионерской работы ведущим было направление воспитания патриота-интернационалиста. В Положении о Всесоюзной ордена Ленина пионерской организации имени В.И. Ленина, в частности, отмечалось, что «пионерская организация воспитывает юных ленинцев в духе интернационализма, укрепляет дружбу с детскими коммунистическими и демократическими организациями всех стран» [14, с. 93]

Публикации рассматриваемого периода свидетельствуют о том, что вопросы интернационального воспитания детей всегда были в центре внимания Коммунистической партии, Ленинского комсомола и пионерской организации. Так, Е. Сахарова подчеркивала, что «пионерская организация, которая объединяла детей всех национальностей Советского Союза, одним из своих основных задач считает воспитание пионеров в духе дружбы народов СССР с пионерами социалистических стран, с детьми трудящихся всего мира» [15, с. 74-75].

Задачи интернационального воспитания пионеров выплывали из общей направленности воспитания подрастающего поколения - формирования всесторонне развитой личности, основными чертами которой были: верность делу коммунизма и непримиримость к его врагам, трудолюбие и нетерпимость к тунеядству, братская солидарность с трудящимися всех стран.

Интернациональная направленность деятельности пионерской организации была отображена в Торжественном обещании и Законах пионеров Советского Союза, в пионерских символах и атрибутах, в содержании программы Всесоюзного марша юных ленинцев. В них были отражены идеи пролетарского интернационализма, коллективная деятельность пионеров по воплощению их в жизнь, что способствовало «воспитанию интернационалистской убежденности, выработке единства интернационалистского сознания и поведения [ 16, с. 79$]$.

Так, социалистический патриотизм и пролетарский интернационализм подчеркивались в Законах как главные качества пионера (8-й Закон «Пионер - друг пионерам и детям трудящихся всех стран»). В соответствии с 8-мым Законом пионеры обязались укреплять дружбу с детьми других стран, делать всё во имя мира на Земле. Учителя, классные руководителя, вожатые организовывали работу по выполнению пионерами Законов. Например, в программе «Ориентир» были указания для учителей о том, как воспитывать высокое чувство гордости единством всех республик Советской страны, чувство братства и равенства детей всех национальностей. Что касается 8-го Закона, в «Ориентире» были очерчены соответствующие направления для пионеров младшего возраста: «Пионеры СССР, пионеры социалистических стран», среднего возраста: «За мир и дружбу на Земле» и старшего возраста: «За мир во всем мире» $[17$, с. 21$]$.

Во Всесоюзном марше пионерских отрядов (19701986 гг.) ведущими были маршруты «Моя Родина СССР» и «Мир и солидарность», которые способствовали вовлечению школьников в активную политическую жизнь, расширяли их кругозор, воспитывали гражданственность, формировали навыки общественно полезной деятельности. Содержание работы на маршруте «Мир и солидарность» практически реализовывал выполнение пионерами закона «Пионер - друг пионерам и детям трудящихся всех стран».

Маршрут «Мир и солидарность» был частью Всемирной кампании «Юность обличает империализм». Принимая участие в нем, дети учились понимать идеи пролетарской солидарности, пролетарского братства, понимать смысл лозунга «Пролетарии всех стран, соединяйтесь!» $[18$, с. 4].

На маршруте «Мир и солидарность» пионерские отряды должны были:

- воспитывать пионеров в духе братской дружбы народов и пролетарского интернационализма, учить доказывать преимущества советского образа жизни перед капиталистическим, горячо откликаться на события, происходящие в стране и за рубежом;

- знакомиться с тем, как партия и советский народ вели борьбу за мир и безопасность народов, как претворялась в жизнь Программа мира, как помогали друг другу страны социализма;

- стремиться больше узнать о борьбе коммунистических и рабочих партий, союзов молодежи, о жизни зарубежных пионеров, принимать участие в кампании «Молодёжь за антиимпериалистическую солидарность, мир и прогресс», всемирной кампании «Нет - нейтронной бомбе!»;

- принимать активное участие в работе клубов интернациональной дружбы, в Неделях солидарности, в ме- 
роприятиях, проводимых СИМЕА (Комитетом детских и юношеских организаций при ВФДМ);

- вносить свой вклад в Фонд мира, участвовать в операции «Подарок советского пионера вьетнамскому другу» [19, с. 103].

Таким образом, наличие у пионерской организации программы деятельности в виде Всесоюзного марша пионерских отрядов обеспечивала систематичность интернационального воспитания, устраняла эпизодичность и случайность в работе и связывала интернациональное воспитание с другими направлениями воспитания пионеров. При этом программа позволяла отбирать содержание работы пионерского коллектива, который был бы общим для всей организации и в то же время воплощать его в конкретные формы с учетом местных условий, опыта пионерской жизни, традиций и перспектив пионерского коллектива.

Таким образом, в процессе научного поиска мы выяснили, что интернациональное воспитание в 60-80-х гг. XX в. было важным направлением содержания деятель- ности пионерской организации. Это была продуманная система целенаправленного систематического воздействия на личность школьников с целью формирования у них чувств, взглядов и убеждений, навыков и привычек интернационалистского поведения. Эта система включала цель и задачи, формы и методы воспитания, которые переплетались с другими направлениями коммунистического воспитания (идейно-политическим, умственным, нравственным, трудовым, физическим, эстетическим) на основе комплексного подхода к воспитанию

Комплексный подход к интернациональному воспитанию означал, что, во-первых, в ходе его осуществления реализовывались также задачи других направлений воспитания; во-вторых, в содержании интернационального воспитания объединялись разные виды деятельности, которые подчинялись одной идее - воспитание в духе дружбы народов; в-третьих, в рамках интернационального воспитания существовала связь между отдельными видами деятельности.

Литература:

1. Заслуженюк, В. С. Воспитание учащихся на идеях и традициях дружбы народов СССР / Под ред. доктора исторических наук, професора В.А. Чирко. - К.: Радянська школа, 1983. - 215 с.;

2. Жумаканов, А. Р. Патриотическое и интернациональное воспитание в школе / А. Р. Жумаканов. - Алма-Ата: Изд-во «Мектеп», 1971.- 140 с.

3. Ширвиндт, Б.Е. Проблемы содержания идейно-политического воспитания пионеров / Б. Е. Ширвиндт // Идейно-политическое воспитание юных пионеров: материалы Всероссийской научно-практической конференции, проведенной 14-16 февраля 1977 г. в г. Москве. - М., 1977. - с. 4-19.

4. О подготовке к 50-летию образования Союза Советских Социалистических Республик: Постановление ЦК КПСС // Правда. - 1972. - 22 февраля.

5. Верба, И.А., Пиковский В. И. Воспитание патриотов-интернационалистов. Опыт внеклассной и внешкольной работы / И.А. Верба, В. И. Пиковский. - М.: Педагогика, 1973. - 112 с.

6. Сухомлинский, В.А. Сердце отдаю детям / В.А. Сухомлинский. - К.: Рад.школа, 1988. - 272 с.

7. Макаренко, А. С. Цель воспитания // Пед. соч. В 8 т. Т. 4. - М.: Педагогика, 1984. - с. $41-49$.

8. Заслуженюк, В.С. Виховання школярів на ідеях і традиціях дружби народів СРСР (До 60-річчя утворення СРСР) / В. С. Заслуженюк. - К.: Знання, 1982. - 31 с.

9. Опаленик, О.В. Героїко-патріотичне і інтернаціональне виховання учнів / О.В. Опаленик // Радянська школа. - 1983. - № 9. - с. 38-43.

10. Опаленик, О.В. Єдність патріотичного та інтернаціонального виховання / О.В. Опаленик // Радянська школа. - 1986. - № 1. - с. 50-53.

11. Інтернаціональне і національне в соціалістичному суспільстві / Відповідальні редактори: Головаха І. П., Доронченков А. І. / За ред.. С. М. Перевертун. - К.: Наукова думка, 1973. - 179 с.

12. Пряникова, В. Г. Интернациональное воспитание в коллективе школьников (На опыте работы КИДа): кн. для учителя / под ред. З.И. Равкина / В. Г. Пряникова. - М.: Просвещение, 1987. - 128 с.

13. Мухаммедов, М.А. Интернациональное и патриотическое воспитание учащихся: Учеб. пособие / М. А. Мухаммедов. - Казань: КГПИ, 1981. - 112 с.

14. Положение о Всесоюзной ордена Ленина пионерской организации имени В. И. Ленина. Утверждено Бюро ЦК ВЛКСМ 17 марта 1967 г. // Мальцева Э.А. Учителю о работе по Законам пионеров Советского Союза. — M.: Просвещение, 1972. - с. 93-100.

15. Сахарова, Е. В. Проблемы интернационального воспитания в пионерской организации / Е.В. Сахарова // Идейно-политическое воспитание юных пионеров: материалы Всероссийской научно-практической конференции, проведенной 14-16 февраля 1977 г. в г. Москве. - М., 1977. — с. 74-79.

16. Синицина, Л.А. Из опыта патриотического и интернационального воспитания пионеров / Л.А. Синицина // Идейно-политическое воспитание юных пионеров: материалы Всероссийской научно-практической конференции, проведенной 14-16 февраля 1977 г. в г. Москве. - M., 1977. — с. 79-82. 
17. Мальцева, Э.А. Учителю о работе по Законам пионеров Советского Союза / Э. А. Мальцева. - М.: Просвещение, $1972 .-111 \mathrm{c}$.

18. Фуриев, С.А. Маршрут «Мир и солидарность» / С.А. Фуриев. - М.: Молодая гвардия, 1971. - 48 с.

19. Теория и методика пионерской работы: Учеб. пособие для учащихся пед. училищ / В.В. Лебединский, А. А. Деркач, А. Г. Зуев и др. / Под ред. В. В. Лебединского. - М.: Просвещение, 1979. - 270 с.

\section{Показатели понимания содержания текста на иностранном языке}

Комарова Елена Васильевна, кандидат филологических наук, старший преподаватель кафедры иностранных языков Пензенский государственный университет архитектуры и строительства

Данная статья посвящена анализу показателей понимания содержания иноязычного текста. В процессе преподавания иностранного языка преподаватель не может ограничиться одним из способов контроля понимания. Преподаватель должен понимать, что по одному показателю невозможно с уверенностью судить о том, насколько полно и правильно понимается учащимися читаемый ими текст.

Ключевые слова: чтение, процесс обучения, семантизация, перевод, иностранный язык.

$\mathrm{O}$ владение чтением на иностранном языке является сложным механизмом. Задача обучения научить учащихся беспереводному пониманию иноязычного текста - требует выявления закономерностей этого процесса. При этом преподавателю важно знать, имеются ли какие-либо объективные показатели, по которым можно судить, насколько хорошо или плохо понят учащимися текст. К показателям можно отнести:

1. Нахождение в тексте предложений, являющихся ответами на вопросы, поставленные преподавателем. Данный показатель не является надежным, так как может случиться так, что читающий, не поняв общего содержания, поймет лишь те предложения, которые являются контрольными. Выбор ответа будет правильным, однако он не является индикатором понимания всего текста. Однако, возможно и обратное: понимая содержание в целом, читающий не понимает предложения, которое преподаватель обозначил как контрольное. В качестве способа контроля этот прием требует строгого и продуманного использования. Необходимо учитывать индикативную ценность контрольного предложения для всего текста. Следует также отметить, что не для всякого текста этот прием будет показателем понимания. Иногда встречаются тексты, содержание которых раскрывается в одной фразе. В этом случае прочтение этой фразы в ответ на контрольный вопрос и есть свидетельство понимания его смысла. Однако таких фраз может и не встретиться в тексте. [3, с.90]

2. Ответы на любые вопросы по прочитанному материалу. Надежность этого показателя может быть повышена в результате увеличения числа вопросов. Данный показатель становиться более надежным при постановке вопросов к логическим предложениям в тексте.

3. Ответы на вопросы к подтексту.
4. Составление учащимися логической серии вопросов ко всему тексту или частям текста.

5. Составление плана пересказа прочитанного текста. Учащийся сможет составить такой план только в том случае, когда он хорощо понял текст. Однако здесь есть одна трудность. С одной стороны, план может быть слишком общим, с другой стороны, возможна чрезмерная детализация одних частей и опущение других. Причинами могут быть непонимание каких-либо деталей, стремление к большему обобщению или случайное опущение. В таком случае преподаватель модет попросить внести корректировки в План к той части текста, в отношении которой возникло сомнение. Правильное выполнение дополнительного задание будет свидетельствовать о об адекватности понимания.

6. Свободное воспроизведение текста на родном или иностранном языке.

7. Составление учащимися предложений с целью проиллюстрировать употребление отдельных слов, которые являются существенными для раскрытия содержания текста. При этом в качестве контрольных следует выбирать такие слова, значение которых могло быть выявлено читающим только в результате понимания всего текста. Этот прием требует от преподавателя тщательного предварительного изучения текста и применим далеко не ко всякому тексту и не на любом этапе понимания текста. [4]

8. Объяснение значения некоторых слов, ранее читающему не известных. но которые он мог уяснить при условии понимания всего сообщения.

9. Выделение интонацией отдельных наиболее важных по содержанию предложений.

10. Темп чтения текста. Достаточно ненадежный показатель, так как он никак не коррелирует с успеваемо- 
стью студентов. Замедление темпа чтения на иностранном языке может быть не связано с трудностями понимания, но данное соотношение не выявлено в достаточной мере и не носит характера закономерности. [2]

11. Внутренняя речь. этот показатель является самым надежным. Выявленность внутренней речи повышается при речевой деятельности, вызывающей затруднения, например, при переходе от чтения на родном языке к чтению на иностранном или при переходе от чтения легкого к трудному иноязычному тексту. Однако этот показатель понимания практически невозможно контролировать в условиях обычного учебного процесса.

12. Воспроизведение текста - также ненадежный показатель, так как содержание текста воспроизводится со значительными опущениями и едва ли можно судить на основании такого укороченного пересказа о степени понимания оригинала.

13. Перевод. Данный показатель обладает значительно большей надежностью. Однако при переводе, так же как и при пересказе, встречаются опущения и неточности. Причиной может служить незнание большого контекста или отсІутствие определяющего контекста, а также незнание некоторых слов и выражений, домыслы и фантазия.

14. Тест - наиболее распространенный показатель. его особенность состоит в объективности, независимости от мнения преподавателя, основанного на его личных симпатиях или антипатиях. Для того чтобы выбрать правильный ответ, студенты должны прочитать и проанализировать весь текст, соотнести вопрос и варианты ответа между собой и сделать свой выбор. Наличие вариантов для ответа является мощной опорой для студентов. Для контроля понимания в процессе чтения наиболее распространены такие виды тестов как тесты на выбор правильного ответа из нескольких предложенных вариантов, тесты на завершение начатого высказывания на основе предложенных тезисов, тесты на восстановление логического порядка предложений текста и тесты на перекрестный выбор, то есть установление соответствий. [6, с.11]

15. Чтение со словарем. Данный вид чтения является сложным видом речевой деятельности и состоит из ряда навыков и частных умений, что обуславливает многообъектность контроля и трудность в установлении самих его объектов. Многообразие компонентов умения читать с использованием словаря требует проверки уровня сформированности всех его составляющих, а именно уровня сформированности навыка использования словаря, степени совершенства умения рационально использовать словарь в процессе чтения, уровня понимания прочитанного. Важным объектом контроля любого вида чтения является уровень понимания. Ведь цель процесса чтения заключается в достижении заданного уровня понимания иноязычного текста. Это конечный результат всех операций и действий по быстрому отыскиванию слов, по минимизации числа поиска слов в словаре в процессе чтения, по декодированию смысла читаемого до обращения к словарю. В процессе становления умения чтения с рациональным использованием словаря выделенные объекты контроля выстраиваются в обратной последовательности, то есть уровень понимания, умение рационально использовать словарь и навык пользования словарем. [ 1, с.80]

Важным моментом является то, что выделенные объекты контроля не статичны в процессе чтения, а подвижны и их роль меняется в зависимости от стадии обучения

Для правильной организации и проведения контроля необходимо четко представлять его объекты в процессе обучения иноязычным видам речевой деятельности.

Согласно ФГОС можно выделить в контексте формирования смыслового чтения можно выделить несколько показателей. К ним относятся виды чтения, типы чтения, умения полноты понимания текста, определение понятия «текст», выделение пяти уровней грамотности чтения, анализ чтения художественного текста по Гальперину, приемы организации эффективного обучения чтению, умения чтения. [5, с.2]

На практике в процессе преподавания иностранного языка преподаватель не может ограничиться одним из способов контроля понимания. О понимании текста следует судить на основании анализа нескольких показателей. Преподаватель должен понимать, что по одному показателю невозможно с уверенностью судить о том, насколько полно и правильно понимается учащимися читаемый ими текст. При этом следует иметь в виду, что использование способов контроля может определяться и специфическими особенностями текста, например, воспроизведение текста возможно в том случае, если текст не будет профильным, тяжелым для пересказа.

Разработка объективных критериев понимания - довольно сложная задача. Возможность иметь объективные показатели степени понимания текста нужна не только в практике обучения. Наличие разработанных критериев понимания речевого сообщения позволило бы с большей тщательностью изучить процесс понимания речи, усовершенствовать методику обучения беспереводному чтению иноязычного текста.

Литература:

1. Вейзе, А.А. Чтение, реферирование и аннотирование иностранного текста: Учеб. пособие. - М.: Высш. шк., 1985. - 127 c

2. Қаргина, Е. М. Работа над профильными иноязычными текстами как основа развития устной речи студентов // Гуманитарные научные исследования. - 2014. - № 11 (39). - c. 108-111.

3. Қлычникова, 3.И. К вопросу о показателях понимания содержания иноязычного текста// Психология в обучении иностранному языку. Сборник статей. - М.: Просвещение, 1967. - 183 с. 
4. Комарова, Е.В. Формирование речевого механизма в процессе усвоения лексики на иностранном языке // Гуманитарные научные исследования. 2015. № 2 [Электронный ресурс]. URL: http://human.snauka. $\mathrm{ru} / 2015 / 02 / 9645$

5. Соловова, Е. Н. Чтение в составе универсальных учебных действий: позиции ФГОС и традиционной методики обучения иностранным языкам// Иностранные языки в школе. - 2014. - № 4.

6. Тен, Е.Г. Организация контроля понимаеия читаемого на начальном этапе обучения// Иностранные языки в школе. - 2004. - № 4 .

\section{Реферирование как один из самых распространенных приемов работы с иноязычным текстом в процессе обучения иностранному языку в вузе}

Комарова Елена Васильевна, кандидат филологических наук, старший преподаватель Пензенский государственный университет архитектуры и строительства

Данная статья посвящена анализу реферирования как одного из самых распространенных приемов работы с иноязычным текстом в процессе обучения иностранному языку в вузе. Определень функции и виды рефератов, а также приведен алгоритм составления реферата. Рассмотрен пересказ как особый вид реферирования текста.

Ключевые слова: реферирование, пересказ, перефразирование, чтение, контроль, прочесс обучения, перевод, иностранный язык.

$\prod$ ри обучении иностранному языку в вузе на первое место выходит обучение аннотированию и реферированию иноязычного текста. Реферирование можно охарактеризовать как рецептивно-репродуктивную речевую деятельность. На начальном этапе приема информации речевые действия учащихся направлены на декодирование информации иноязычного текста. На следующем этапе происходит смысловая переработка информации. Реферирование способствует развитию логичности изложения материала и формирует речевые навыки и умения.

Реферирование выполняет также функцию контроля. Быстрая переработка смысловой информации иноязычного текста говорит о хорошем уровне владения иностранным языком и является показателем сформированности умений зрелого чтения. Реферат - это, прежде всего, текст, построенный на смысловом сжатии исходного текста с целью передачи его главной мысли. [1, с. 103]

Основным критерием оценки реферата является критерий семантической эквивалентности оригинала и конечный текст после смысловой компрессии. Реферирование тесно связано с устранением избыточной лишней информации. Используются такие умения как абстрагирование и обобщение, что находит отражение в работе с ключевыми словами и словосочетаниями. Очень важно вычленить правильные ключевые слова, которые в конечном итоге позволят выразить основное содержание иноязычного текста. [4, с.10]

Главными признаками ключевых слов являются:

1. Номинативность, то есть они должны быть существительными или сочетанием существительного с другой частью речи;
2. Воспроизводимость, то есть эти слова должны выступать в качестве готовых компонентов текста;

3. Постоянство значения.

Существуют различные виды рефератов. Рефераты могут быть по характеру исходного материала монографические и обзорные. По типам отдельных видов операций свертывания текста различают рефераты-выдержки, рефераты-цитаты, рефераты-перифразы и рефераты-обобщения. По типам организации ключевого материала во вторичном тексте могут быть реферат-конспект и реферат-резюме. Реферат-конспект и реферат-резюме используются также для контроля понимания прочитанного. [2]

В процессе составления реферата учащиеся выполняют следующие действия:

1. Выделение ключевых слов;

2. Анализ логической структуры исходного текста. Можно использовать работу с построением текстовых схем. Однако при зрелом чтении схема составляется «про себя» и учащийся переходит уже непосредственно к составлению логического плана текста.

3. Перегруппировка фрагментов иноязычного текста и составление логического плана. Чаще всего обобщающие формулировки находят выражение в номинативных словосочетаниях и обозначаются римскими цифрами. Затем каждая формулировка раскрывается в ряде тезисов, обозначаемых уже арабскими цифрами. Возможно, при записи формулировок следовать за логикой изложения материала в оригинальном текста, а можно создать свой порядок изложения. Рекомендуется применять рамочную структуру текста, в которой ключевая мысль выражается в первом и последнем абзацах текста. 
4. Составление и редактирование текста реферата. Реферат составляется на основе ключевых слов и выражений, некоторые из них используются без изменений. Однако в некоторых случаях требуется трансформация исходных словосочетаний и предложений.

Следует помнить о том, что реферат - это самостоятельный текст со своей собственной логикой изложения, которая требует введения ряда связующих переходных элементов, которые обеспечат связность нового текста. При составлении реферата активно используются такие виды языковой трансформации, как перифразирование, обобщение и абстрагирование. [3]

При работе с текстом в процессе обучения иностранному языку важно адаптировать текст для каждой конкретной группы учащихся. Студенты могут сами выполнять данную операцию, в частности, это может быть эффективным как вид письменной работы при обучении письму. На первом этапе осуществляется сокращение объема оригинального текста, при это должна быть сохранена его смысловая ценность, его структурные особенности и связи между его частями. Другими словами, текст упрощается на уровне смысла, а не языкового оформления. На втором этапе производится языковая обработка текста. Она включает в себя синонимические замены неизученных грамматических явлений изученными ранее и упрощение структуры предложения. Замены одних структур другими основаны на грамматической синонимии. Кроме того имеет место работа по уменьшению количества незнакомых слов для студентов. Лексические замены могут осуществляться с помощью слов общелитературного языка, терминов, свободных словосочетаний, фразеологизмов, устойчивых словосочетаний терминологического характера. В случае крайней необходимости используется логико-смысловой перифраз. [6, с.18]

Смысловая обработка, редукция и упрощение учебных текстов путем постепенного, планового введения наиболее частотной лексики и временного исключения наиболее сложных грамматических явлений обеспечивает плавное нарастание языковых трудностей, что в свою очередь рационализирует процесс становления умений по чтению текста в оригинале и обеспечивает успешное продвижение вперед в овладении иностранным языком.

В процессе обучения иностранному языку в вузе преподаватель должен научить студентов оформлять заголовочную часть реферата ( то есть название, автор, выходные данные, количество страниц), логически разделять текст на коммуникативные блоки, вычленять основную информацию в целом тексте в форме ключевых слов и словосочетаний, составлять план реферата, развертывать план в тезисы, редактировать текст реферата, вводить в него переходные элементы, формулировать главное содержание исходного текста в 3-4 предложениях.

Реферирование может включать в себя изложение иноязычного текста как на родном языке учащихся, так и на иностранном. Реферативный перевод - это сжатие главного содержания исходного текста и передача его на иностранном языке. Он представляет собой форму реферирования и смысловую редукцию текста.

Рассмотрим пересказ текста как особый вид реферирования текста. Итак, пересказ строится на смысловом сжатии исходного текста, то есть это краткое изложение текста с целью передачи его основной информации. Бывает устный и письменный. Для пересказа характерно наличие обобщений читателя на основе его жизненного опыта. Формулировки часто выражены с помощью набора клише. Пересказ не регламентирован жесткими рамками в отношении объема и формы изложения материала.

Сходство между пересказом и рефератом заключается в смысловой редукции содержания. Различие состоит в том, что в реферате главным является фактологический материал, а в пересказе интерпретация и оценка фактов. Однако пересказ может привести к недопустимой смысловой деформации оригинала, к провалам в передаче фактологической цепочки, к неоправданным произвольным перестановкам смысловых звеньев. [5, с.15]

Пересказ может выступать как показатель контроля понимания прочитанного текста. В данном случае возможны два варианта:

1. Пересказ на родном языке;

2. Пересказ на иностранном языке.

На занятиях по иностранному языку пересказ обычно выступает как один из самых распространенных способов работы с текстом. Так как не существует четких критериев оценки воспроизведения текста, преподаватель, как правило, оценивает ответ учащегося с точки зрения отсутствия грамматических ошибок. Содержательная же сторона пересказа оценивается очень субъективно.

Все виды работы над текстом носят коммуникативный характер, то есть в результате работы получается речевой продукт, идентичный исходному по коммуникативной ценности.

Литература:

1. Вейзе, А. А. Чтение, реферирование и аннотирование иностранного текста: Учеб. пособие. - М.: Высш. шк., 1985. - $127 \mathrm{c}$.

2. Қаргина, Е.М. Особенности обучения реферированию профильной профессионально-ориентированной литературы на иностранном языке // Современные научные исследования и инновации. -2014 . - № $12-3$ (44). - c. 106-111.

3. Комарова, Е. В. Трудности употребления иноязычной лексики в процессе обучения иностранному языку // Сoвременные научные исследования и инновации. 2015. - № 2 [Электронный pecypc]. URL: http://web.snauka. $\mathrm{ru} /$ issues/2015/02/47166 
4. Саланович, Н.А. Роль и место чтения художественных текстов на старшей ступени обучения// Иностранные языки в школе. - 2001. - № 3 .

5. Салтовская, Г.Н. Приемы обучения проблемно-поисковому чтению на иностранном языке// Иностранные языки в школе. - 2006. - № 2 .

6. Соловова, Е.Н. Чтение в составе универсальных учебных действий: позиции ФГОС и традиционной методики обучения иностранным языкам// Иностранные языки в школе. - 2014. — № 4.

\title{
Повышение качества обучения в вузе в условиях интеграции смешанной модели обучения
}

\author{
Краснова Татьяна Ивановна, старший преподаватель \\ Национальный исследовательский Томский политехнический университет
}

Ключевые слова: качество обучения, информационно-коммуникационные технологии, компетентностный подход, смешанное обучение.

П одготовка высококвалифицированных специалистов и повышение их конкурентоспособности в условиях непрерывного роста потока информации и развития новых информационно-коммуникационных технологий выдвигает на первый план необходимость преобразований. В рамках модернизации российского образования становится приоритетным компетентностный подход, нацеленный на достижение новых образовательных результатов, способствующих комплексному развитию профессиональных компетенций будущих специалистов. Конкурентные преимущества выпускников вузов заключаются не только в конкретных знаниях, но и в новых универсальных способностях личности и поведенческих моделях [1, 430]. В связи с этим, первостепенной задачей высшей школы на нынешнем этапе является повышение эффективности и качества обучения, что влечет за собой создание концепций повышения качества обучения и качества подготовки специалистов в вузе. Данные концепции будут являться основой для разработки технологий, методов и форм обучения, обеспечивающих качество подготовки специалистов и развитие их творческого потенциала в образовательном процессе [2, с. 3].

Качество образования напрямую зависит от преподавателя, который должен быть ориентирован не только на пополнение багажа знаний студентов, но и на раскрытие творческих и интеллектуальных способностей в самостоятельной деятельности студентов, на формирование у студентов навыков критического мышления. В пункте 7.3. Федерального государственного образовательного стандарта высшего профессионального образования подчеркивается, что реализация компетентностного подхода должна предусматривать широкое использование в учебном процессе активных и интерактивных форм проведения занятий (компьютерных симуляций, деловых и ролевых игр, разбора конкретных ситуаций, психологических и иных тренингов) в сочетании с внеаудиторной работой с целью формирования и развития профессиональных навыков обучающихся. Говорится также о том, что изменение удельного веса занятий, проводимых в интерактивных формах, определяется главной целью ООП, особенностью контингента обучающихся и содержанием конкретных дисциплин, и в целом в учебном процессе они должны составлять не менее 30 процентов аудиторных занятий [3, с.18].

Обеспечить активную познавательную деятельность студентов и внедрение интерактивных форм занятий призваны информационно-коммуникационные технологии, наиболее эффективной из которых на сегодняшний день является смешанное обучение. Смешанное обучение включает в себя онлайн обучение и традиционное обучение в аудитории с преподавателем. Иными словами, инновационные технические достижения электронного обучения сочетаются с проверенным годами опытом традиционного взаимодействия студентов и преподавателя в рамках аудиторных занятий [4, с.11]. Интеграция модели смешанного обучения в образовательный процесс вуза является одним из конструктивных изменений, положительно влияющих на качество обучения. Данный процесс является закономерным и типичным для всего мирового сообщества. Во многих странах мира смешанное обучение находится на стадии внедрения и апробации. По мнению отечественных специалистов, смешанное обучение имеет большой потенциал в модернизации системы образования.

Исследования ведущих методистов показывают, что для повышения качества и эффективности образовательного процесса необходимо использовать принцип активности и самостоятельности обучающихся в образовательном процессе. Данная цель достижима как раз в контексте смешанного обучения, где очень высока доля самостоятельной работы студентов за счет электронного компонента курса, размещенного в обучающей электронной среде. Студенты получают неограниченный доступ к образовательным ресурсам в любое удобное им 
время. Работая с электронным компонентом смешанного курса, студенты имеют большие возможности для исследовательской и творческой деятельности, что стимулирует развитие их творческих способностей, делает усваиваемые знания глубже и прочнее, повышает интерес к изучаемому предмету [5, с.285].

Комбинирование традиционного и электронного обучения должно быть тщательно организованно и иметь четкую структуру. От организационно-структурного аспекта зависит достижение оптимальных результатов обучения, так как все элементы учебного процесса должны взаимодействовать и дополнять друг друга, образуя единое целое. Работа в электронной среде помогает организовать самостоятельную работу студентов, предлагая виды заданий, которые недоступны на аудиторном занятии (форумы, чаты, вики, опросы и т.д.).

C внедрением смешанного обучения увеличивается скорость подачи качественного материала в связи с возможностью моментальной публикации в электронной среде, расширяется также зона индивидуальной активности студентов. Большая вариативность онлайн заданий и тестов открывает возможность создания индивидуальной траектории обучения для каждого студента, что, несомненно, отразится на конечном результате. Студентам предоставляется возможность выбора, что, по существу является основой любого творчества [6, с.520]. Наличие индивидуальной траектории обучения позволяет реализовать личностно-ориентированный подход при организации образовательного процесса, что гарантирует повышение мотивации и достижение личностных результатов обучения. Таким образом, можно говорить о том, что модель смешанного обучения способствует индивидуализации обучения и его адаптации к познавательным потребностям обучаемых.

Студенты при таком подходе становятся субъектами обучения наряду с преподавателем. Преподаватель перестает выполнять доминирующую роль, он сопровождает деятельность студентов в смешанном курсе обучения, вы- ступая уже не в качестве транслятора знаний, а в качестве эксперта и помощника. Студент, таким образом, оказывается в центре обучения, и все методические решения преломляются через призму личности обучаемого [7, с. 230]. Но в то же время роль преподавателя во взаимодействии участников смешанного обучения чрезвычайно важна: именно он подбирает приемлемые дидактические средства и вписывает их в процесс обучения и всю систему взаимодействия, тем самым выстраивая собственную образовательную стратегию [8, с. 33].

Контроль знаний студентов является одним из основных элементов оценки качества обучения. Но контролирующие мероприятия должны играть лишь вспомогательную роль. Куда более важным является постоянное отслеживание и анализ текущей деятельности студентов. Электронная обучающая среда оснащена автоматической системой проверки работ студентов, благодаря чему преподаватель может осуществлять постоянный мониторинг их деятельности в сети. Статистические отчеты по каждому студенту показывают степень успешности выполнения тестов, что дает полную картину о пробелах в знаниях и позволяет корректировать их. Важную роль здесь также играет система обратной связи, позволяющая преподавателю и студенту поддерживать постоянную связь, обсуждать и анализировать ошибки. Мониторинг успеваемости позволяет выявлять не только пробелы в знаниях студентов, но и слабые и сильные стороны различных методов и технологий обучения.

Таким образом, мы видим, что главной особенностью ФГОС третьего поколения является обучение, основанное на компетентностном подходе, которое означает способность обучающегося к успешной профессиональной деятельности. В решении данной задачи определяющее значение приобретает модель смешанного обучения, позволяющая организовать активную учебную деятельность, и тем самым существенно повысить эффективность и качество обучения студентов.

Литература:

1. Макарова, О.А. Модель и диагностика конкурентоспособных качеств выпускника средней школы с профильным обучением //Известия Российского государственного педагогического университета им. Герцена. 2007. № 40 (16). с. $427-432$.

2. Соколова, И. Ю., Кабанов Г. П. Качество подготовки специалистов в техническом вузе и технологии обучения. Учебное пособие для педагогов, аспирантов, магистрантов. Томск: Изд-во ТПУ, 2003. 203 с.

3. Федеральный государственный образовательный стандарт высшего профессионального образования по направлению подготовки 051000 «Профессиональное обучение» (по отраслям) (квалификация (степень) «бакалавр») от 22 декабря 2009 г. № 781 (режим доступа http://минобрнауки.рф/документы/1912)

4. Краснова, Т.И. Смешанное обучение: опыт, проблемы, перспективы // В мире научных открытий. 2014 . № 11. c. $10-26$.

5. Краснова, Т.И. К вопросу об организации СРС по иностранному языку в вузе // Уровневая подготовка специалистов: государственные и международные стандарты инженерного образования: сборник трудов научно-методической конференции, 26-30 марта 2013 г., Томск / Национальный исследовательский Томский политехнический университет (ТПУ); ред. кол. А. И. Чучалин [и др.]. Томск: Изд-во ТПУ, 2013. с. 284-286.

6. Краснова, Т.И. Принцип индивидуализации в контексте смешанного обучения иностранному языку в вузе // Молодой ученый. - 2014. - № 7 (66). с. 519-521. 
7. Сурхаев, М.А. Развитие системы подготовки будущих учителей информатики для работы в условиях новой информационно-коммуникационной образовательной среды. Дис. д-ра пед. наук: 13.00.02/13.00.08. - M., 2010. - 337 с.

8. Искаков, Б.А., Сахариева С. Г. Взаимодействие субъектов образовательного процесса в условиях традиционного и электронного обучения // Мир науки, культуры, образования. - 2011. — № 4-2. с. 30-33.

\title{
Перспективы использования смешанного обучения при обучении иностранному языку
}

\author{
Краснова Татьяна Ивановна, старший преподаватель \\ Национальный исследовательский Томский политехнический университет
}

Ключевые слова: информационно-коммуникационные технологии, система управления обучением, смешанное обучение.

$\prod^{1}$ редметно-знаниевая парадигма долгие годы доминировала в образовательном процессе высших учебных заведений, но под воздействием факторов экономической и социокультурной ситуации мы наблюдаем череду изменений, которые нашли отражение в последней версии федеральных государственных образовательных стандартах (ФГОС). В соответствии с новыми стандартами инженерное образование в России должно отвечать насущным потребностям общества и личности. В этой связи возникает главная проблема: того багажа знаний, который выпускники традиционно получали в вузе, в современных условиях уже недостаточно. Профессиональная деятельность с каждым годом становится все более интеллектуальной и многоплановой, требующей нестандартности мышления. Таким образом, реалии современного общества требуют постоянного обновления имеющихся знаний и компетенций, непрерывное обучение становится частью профессиональной деятельности. И именно компетенции, а не привычная триада «знания, умения, навыки» приобретают первостепенное значение. Особенно важны такие компетенции как:

- способность обрабатывать, структурировать, аналитически осмысливать большие объемы разнородной и разноплановой информации;

- способность творчески работать с информацией в сжатые сроки,

- способность генерировать свои идеи, превращая их в инновации;

- способность действовать в ситуации изменчивости, неопределенности и уметь «достраивать» информационную картину мира, гибко приспосабливаясь к изменениям;

- способность к диалогу, толерантному общению, стремление выяснить, что происходит, оказывая влияние на происходящее и изменяясь самому [1, с. 5].

По нашему убеждению, такие требования к современному студенту как: творчество, самостоятельность и инициативность, коренным образом меняют все компоненты образовательного процесса, формируют новые требования к преподаванию и способам получения знаний.
Согласно новым требованиям ФГОС при подготовке специалистов в области инженерной деятельности основополагающим требованием является формирование профессионально ориентированной иноязычной коммуникативной компетенции студентов, которая определяется как «владение иностранным языком на уровне, позволяющем осуществлять профессиональное общение» [2, с. 9]. Неоспоримым дидактическим потенциалом при формировании иноязычной коммуникативной компетенции обладают информационно-коммуникационные технологии, в том числе ресурсы Интернет. Благодаря научно-техническому прогрессу в современных условиях данные технологии активно развиваются и заставляют пересмотреть принципы содержания и организации образовательного процесса в вузе.

В настоящее время при традиционном обучении очень часто фиксируется слабая удовлетворенность студентов и преподавателей от образовательного процесса, имеются также проблемы с результативностью процесса обучения. По мнению автора данной статьи, внедрение ИКТ при подготовке специалистов технического профиля в рамках дисциплины «Иностранный язык» способствует совершенствованию профессиональных компетенций будущих специалистов и является неотъемлемым условием успешного овладения иностранным языком. Поколение современных студентов с раннего детства вовлечено в процесс информатизации, который проник во все сферы деятельности. Они привыкли получать информацию не из книг, а с экранов компьютеров или гаджетов. Поэтому можно считать целесообразным применение ИКТ для активизации и повышения эффективности образовательной деятельности.

За последние годы вузы пережили много преобразований и инноваций, но мало что изменилось в сущности образовательного процесса, так как до сих пор существует авторитарная модель управления и линейная модель обучения. Информационные технологии могут, наконец, переломить ситуацию путем вовлечения студентов в познавательную деятельность, культивирования чувства сопричастности и рефлексии, самостоятельности и ответ- 
ственности за свое обучение, появится многовариантность путей развития субъектов обучения.

Поиск дидактического инструментария для реализации поставленной цели привел нас к методу смешанного обучения (blended learning), который, на наш взгляд, способен обеспечить последовательный переход, как на модульный принцип организации учебного процесса, так и на формирование условий для студентов к автономному обучению [3, с. 406]. Традиционно в смешанном обучении комбинируются аудиторная работа и обучение на базе информационных технологий. Қомпоненты данной системы функционируют в постоянной взаимосвязи и должны быть грамотно методически организованы.

Для реализации учебного взаимодействия необходима среда. В условиях смешанного обучения ею становится электронная образовательная среда, создаваемая на базе системы управления обучением (Learning Management System), которая включает в себя многообразие дидактических систем. Данная среда располагает инструментами, позволяющими разрабатывать контент, распространять через Интернет и использовать встроенные средства совместной работы, совмещать работу и обучение в одном процессе. [4, c. 145]. Эффективность образовательного процесса будет зависеть от соотношения времени, отведенного на аудиторные занятия и работу онлайн, а также от правильно выбранного характера предоставления материала и его содержания.

Традиционно смешанное обучение состоит из комбинации синхронных и асинхронных технологий обучения. При синхронной форме работы преподаватель и студенты одновременно присутствуют в системе обучения и взаимодействуют в реальном времени. Преподаватель может наблюдать за работой студентов и выполнять функции консультанта и модератора. При асинхронной форме работы преподаватель и студенты заходят в электронную среду в удобное для них время. Накопленная статистика позволяет преподавателю отслеживать работу студентов, комментировать и пояснять сложные вопросы, создавая «эффект присутствия». Немаловажным является осуществление мониторинга процесса обучения в виртуальной среде с помощью таких функций, как оценка и самооценка (тесты, различные виды вопросов), обеспечение контакта между преподавателем и студентами, между студентами (чаты, форумы и т.д.) [5, с. 361]. Электронная среда предоставляет разнообразные средства коммуникации, что предполагает активность каждого субъекта образовательного процесса, возрастает количество коммуникативных контактов между самими обучающимися через разнообразную творческую деятельность [6, с. 23].

Ценность смешанного обучения заключается в том, что оно позволяет создать нелинейную модель обучения, где нет жесткой запрограмированности, ограничений во времени, в содержании и в использовании технологий. Здесь отсутствует авторитарное руководство преподавателя, его главной функцией становится сопровождение деятельности студентов и создание благоприятных условий для осуществления успешной учебной деятельности, в которой реализуется личностно-ори- ентированный подход в обучении. Преподаватель поддерживает и развивает личность студента, а отношения между ними строятся на принципах сотрудничества и совместных инициатив [7, с. 97]. Основной задачей преподавателя становится не передача знаний и формирование навыков и умений, а стимулирование интереса, мотивации к усвоению языка, помощь в усвоении и творческом поиске [8, с. 17]. Он помогает понять сам процесс обучения и управлять им самостоятельно, а также раскрыть механизмы добывания новых знаний.

В условиях смешанного обучения студенты получают возможность формировать индивидуальную образовательную траекторию в соответствии с видением своих образовательных перспектив. Смешанное обучение способно приспосабливаться к уровню развития студента и выводить его на более высокий уровень развития в соответствии с требованиями системы $[9$, с. 520]. Современные технологии предлагают неисчерпаемые возможности для реализации на практике вариативности приемов обучения [10, с. 233].

Смешанное обучение становится особенно актуальным и востребованным в силу тенденции к повышению удельного веса самостоятельной индивидуальной работы студентов по усвоению знаний, что соответствует современным европейским образовательным традициям [11, с. 285]. Оно способствует формированию стратегий самостоятельной работы обучающихся, повышает чувство ответственности за организацию траектории внеаудиторного обучения, развивает умение саморегуляции, так как часть учебного процесса вынесена за рамки аудиторных занятий [12, с. 73].

Несколько слов стоит сказать о мотивации в смешанном обучении. Данная проблема особенно актуальна для изучающих иностранный язык, так как это процесс с отложенным вознаграждением, что отрицательно влияет на мотивацию. Владение иностранным языком нацелено на получение дивидендов лишь в будущем, при достижении определенного уровня, причем, для разных студентов в разной степени и в разный срок [13, с. 484]. Особенно тяжело приходится студентам с низким уровнем владения языком, и мы имеем достаточно большое число таких студентов. По данным входного тестирования абитуриентов Национального исследовательского Томского политехнического университета средний балл оценки знаний по иностранному языку составляет $32,3 \%$, что соответствует лишь уровню А2 по Европейской шкале, при этом есть студенты чей уровень едва достигает порогового Al [14, с. 100]. При смешанной модели обучения мотивация поддерживается за счет персонификации образовательного процесса, поддержания атмосферы доброжелательства и ориентации на успех. Мотивация побуждает, направляет и организует обучаемого, придает учебной деятельности личностный смысл и значимость [15, с. 481].

Современное инженерное образование невозможно без применения различных средств информатизации, самым эффективным из которых можно считать смешанное обучение, сущностью которого является самостоятельная познавательная деятельность студентов, основанная на компетентностном подходе. 
Литература:

1. Игнатьева, Е. Ю. Педагогическое управление учебной деятельностью студентов в современном вузе: Монография. - СПб.: Изд-во «ЛЕМА», 2012. - 300 с.

2. Сидоренко, Т.В., Рыбушкина С.В. Дебаты как средство формирования метапредметных компетенций у студентов технического вуза при обучении иностранному языку // Вестник Новосибирского государственного педагогического университета. 2014. № 6. с. 7-21.

3. Краснова, Т.И., Сидоренко Т. В. Смешанное обучение как новая форма организации языкового образования в неязыковом вузе // Образовательные технологии и общество. 2014. № 17 (2). с. 403-414.

4. Розанова, Я.В. Организация проектной работы студентов технических специальностей на английском языке с помощью платформы Moodle // Сибирский педагогический журнал. 2013. №6. с. 144-147.

5. Логинова, А. В. Преимущества использования системы дистанционного обучения "Moodle" при обучении иностранному языку студентов технических специальностей // Вестник науки Сибири. 2011. № 1 (1). с. 358-362.

6. Розанова, Я.В. Использование метода проблемного обучения на занятиях по иностранному языку в вузах технического профиля // Педагогический журнал. 2012. № 5-6. с. 18-30.

7. Бехтерев, А.Н., Логинова А. В. Использование системы дистанционного обучения «MOODLE» при обучении профессиональному иностранному языку // Открытое образование. 2013. № 4. С.91-97

8. Асадуллина, Л.И., Диденко А. В. Средства электронной коммуникации в обучении иностранному языку // Филологические науки. Вопросы теории и практики. 2010. № 1-2. с. 14-17.

9. Краснова, Т.И. Принцип индивидуализации в контексте смешанного обучения иностранному языку в вузе // Молодой ученый. 2014.№ 7 (66). с. 519-521.

10. Сырых, Е. В., Ольховик Н. В. Использование инновационных технологий обучения иностранному языку в технических вузах // Мир образования - образование в мире. 2014. № 2. с. 230-234.

11. Краснова, Т. И. К вопросу об организации СРС по иностранному языку в вузе // Уровневая подготовка специалистов: государственные и международные стандарты инженерного образования: сборник трудов научно-методической конференции, 26-30 марта 2013 г., Томск / Национальный исследовательский Томский политехнический университет (ТПУ); ред. кол. А. И. Чучалин [и др.]. Томск: Изд-во ТПУ, 2013. с. 284-286.

12. Розанова, Я.В. Технология ротационной модели метода смешанного обучения в неязыковом вузе // Научно-педагогический журнал Восточной Сибири Magister Dixit. 2014.№ 2. С.70-76.

13. Аксенова, Н. В., Шепетовский Д. В. Опыт использования сайта duolingo.com в обучении английскому языку студентов технического ВУЗа // Молодой ученый. 2014. № 7. с. 484-486.

14. Аксенова, Н. В., Шепетовский Д. В. Организация внеаудиторной работы студентов как мотивация к изучению английского языка в техническом вузе // Молодой ученый. 2014.№ 7. с. 481-483.

15. Сидоренко, Т. В., Игна О.Н., Рыбушкина С. В., Диденко А. В. К анализу языкового образования в зарубежных неязыковых вузах // В мире научных открытий. 2012. № 9.3 (33). с. $97-118$.

\section{Эффективность смешанного обучения при обучении иностранному языку в условиях современного образования}

Куркан Наталия Владимировна, преподаватель

Национальный исследовательский Томский политехнический университет

В статье рассматривается понятие «смешанное обучение» и его основные составляющие. Анализируются преимущества использования технологии смешанного обучения в процессе преподавания иностранного языка по сравнению с традиционной моделью образования и её эффективность в условиях современного образования.

Ключевые слова: смешанное обучение, преподавание иностранного языка, традиционная модель образования, самостоятельное обучение, онлайн-обучение.

$\mathrm{B}$ современной системе высшего профессионального образования проблема выбора наиболее эффективных инновационных методов и технологий остается значимой и актуальной. Под инновационными методами подразумеваются методы, основанные на использовании современных достижениях науки и информационных тех- 
нологий. [1] Инновационные методы предназначены, прежде всего, оптимизировать учебный процесс, создавать максимально благоприятные условия для усвоения учебного материала, что в итоге способствует повышению качества образования.

Основной целью введения инновационных методов в образование является развитие преподавателем навыков мотивировать студента, ориентироваться в информационном пространстве, формировать творческое нестандартное мышление. Технологичность становится сегодня главной квалификационной характеристикой деятельности преподавателя и означает переход на более высокую ступень организации образовательного процесса. [2] Преподаватель, целью которого является подготовка востребованных специалистов, должен работать в обновленных педагогических ситуациях и владеть различными видами деятельности: научно-исследовательской, инновационной, проектировочной, коммуникационной и другими. [3]

Нововведения в процессе обучения иностранномуязыку затрагивают самые разные аспекты учебного процесса, включая смену организации пространства в учебных аудиториях, оснащение классов современными техническими средствами, а также испытание новых образовательных технологий как на аудиторных занятиях, так и во время самостоятельной подготовки студентов. Методы обучения иностранным языкам, используемые в настоящее время, подразумевают активное использование различных информационных технологий, которые вносят в образовательный процесс доступность, открытость, мобильность. В последнее время наряду со стандартным, аудиторным обучением иностранному в вузах активно используются другие, инновационные, формы обучения, среди которых метод смешанного обучения (blended learning) приобретает все большую популярность. Поскольку смешанное обучение позволяет максимально результативно спланировать время преподавателя и отдельно взятого студента, с одной стороны, а также может сделать процесс изучения языка увлекательным и доступным, с другой стороны, она рассматривается как одна из востребованных и эффективных технологий при изучении иностранного языка. Сегодня смешанное обучение является одним из ключевых конкурентных преимуществ высших учебных заведений. К такому выводу можно прийти, ознакомившись поближе с понятием и основными составляющими данного метода.

Понятие смешанного обучения (blended learning) появилось в начале 2000-х гг. в американских деловых кругах как метод обучения персонала и переподготовки кадров, а позже, после выпуска первых книг авторов Бонк и Грэхэм Handbook of Blended Learning, 2006 г. и Гэррисон и Воган Blended Learning in Higher Education: Framework, Principles, and Guidelines, 2008 г. успешно использовался в системе высшего образования [4]. В отечественной методике преподавания данный метод изучается не так давно, поэтому существующие терминологические определения несколько варьируются (данное обучение называют также комбинированным, гибридным, интегрированным) и при этом носят сугубо описательный характер. Проведем терминологический анализ понятия.

Так, Крис Рид и Харви Синх описывают смешанное обучение как обучающую программу, в которой используется более одного способа подачи материала с целью оптимизировать результаты обучения и расходы на реализацию программы [5]. Здесь также приводится уточнение, что смешанное обучение направлено на оптимизацию достижения целей обучения посредством использования «нужных» технологий обучения («right» learning technologies) с целью передачи «нужных» умений «нужному» человеку в «нужное»время (to transfer «right» skills to the «right» person at the «right» time).

Более развернутое описание смешанного обучения представлено П. Валиатхан, которая определяет, что способы подачи материла при смешанном обучении могут включать аудиторные занятия (face-to-face (F2F) classrooms), электронное обучение (e-learning) и самостоятельное обучение (self-paced learning) [6].

Дарлин Пейнтер формулирует смешанное обучение как объединение строгих формальных средств обучения в аудитории с неформальными средствами [7]. Например, обсуждение по электронной почте, конференц-связь и пр.

В системе высшего образования смешанное обучение понимается как форма обучения, при которой обучение проводится как в традиционной очной форме, так и с использованием технологий дистанционного обучения. Э. Розетт и Р.В. Фрази определяют, что форма смешанного обучения объединяет противоположные, на первый взгляд, подходы — такие как формальное и неформальное обучение, общение «лицом к лицу» и общение «онлайн», управляемые действия и самостоятельный выбор пути для достижения личных целей и целей организации [8].

Проанализировав работы специалистов, представляется возможным сформулировать определение смешанного обучения как метода, включающего режимы дистанционного обучения и аудиторного обучения, при оптимальном сочетании сильных сторон и преимуществ каждого из них (режимов). А также на основании рассмотренных определений представляется возможным назвать следующие компоненты в качестве основных составляющих модели смешанного обучения:

- очное обучение (F2F) представляет собой традиционный формат аудиторных занятий;

- самостоятельное обучение (self-study learning) самостоятельная работа студентов: поиск, изучение и анализ материалов (чаще всего в сети интернет) согласно плану, составленному преподавателем [8];

- совместное обучение онлайн (online collaborative learning), при котором студенты и преподаватели работают с использованием онлайн ресурсов, онлайн технологий и пр. [9]

Использование метода смешанного обучения призвано частично решить основную задачу, существующую 
в настоящее время в преподавании иностранного языка, это - силами ограниченного числа преподавателей помочь большому количеству обучаемых стать «эффективными пользователями» иностранного языка в максимально короткие сроки. Можно предположить, что смешанное обучение вполне способно решить данную задачу и повысить эффективность изучения иностранного языка в современном вузе, поскольку обладает следующим рядом преимуществ по сравнению с традиционной моделью образования:

- смешанное обучение представляет собой гибкую модель, в которой сочетаются виртуальное и непосредственного общение, в рамках которого проводятся дискуссии, обсуждения, обмен опытом и практическими навыками, и глубокое самостоятельное освоение части материала посредством онлайн технологий, что позволяет сохранить время для активной отработки определенных умений и навыков в аудитории;

- смешанное обучение способствует развитию критического мышления и навыков самостоятельной работы, а именно, умение работы с информацией: изучать, анализировать и отбирать материал, который будет использован для обучения, работы и развития;

- в смешанном обучении представление учебных материалов осуществляется не только в печатном, но и в доступных электронных форматах, что позволяет студентам выбирать индивидуальный режим при обучении иностранному языку ( обращаться к материалам необходимое количество раз в удобное для студентов время, в любом месте);

- смешанное обучение предполагает самостоятельное использование электронных ресурсов студентами, что существенно сберегает аудиторное время пре- подавателя, которое ранее использовалось для введения и объяснения материала;

- смешанное обучение является интерактивным методом, что предполагает возможность общения «преподаватель - студент» и «студент - студент» с высказыванием своих точек зрения, обменом мнений, а также возможность влиять на тематическую направленность предлагаемого материала;

- при смешанном обучении учитываются индивидуальные психологические особенности студента, поскольку сочетание разнообразных форм работы предоставляет возможности проявить себя студентам с разными темпераментами и разной скоростью усвоения материала.

Цель данного метода состоит в том, чтобы развить у студентов навык самостоятельного планирования и организации своей деятельности, ориентируя ее на конечный результат. Студенты учатся принимать решения, делать осознанный выбор и нести за него ответственность. У них формируются навыки и умения работать в информационном пространстве, самостоятельно искать, отбирать и анализировать информацию, представлять полученный результат с использованием различных современных технологий. Учитывая концепцию метода смешанного обучения, а также принимая во внимание его цели и выделенные преимущества, есть все основания считать, что метод смешанного обучения, позволяющий организовать обучения на гибкой основе с привлечением дополнительных ресурсов как учебных, так и технологических, способен вывести обучение иностранному языку на новый эффективный уровень и частично ликвидировать те проблемы, которые существуют в системе языкового образования вузов.

Литература:

1. О показателях государственной аккредитации «Методическая работа» и их критериях // Письмо Федеральной службы по надзору в сфере образования и науки Российской Федерации. — № 02-55-77 ин/ак. - 17.04.2006.

2. Вардашкина, Е. В. Использование информационно-коммуникационных технологий в обучении английскому языку студентов неязыковых вузов // Инновации и современная наука: материалы международной заочной научно-практической конференции. Ч ІІ. - Новосибирск, 2011. - С.27-32

3. Кудряшова, А. В., Горбатова Т.Н. Роли преподавателя в процессе развития творческой самостоятельности студентов высших учебных заведений // Молодой ученый. - 2015. - № 4. - c. 577-580.

4. Friesen, N. Defining Blended Learning. [Электронный ресурс]. - Режим доступа: http://learningspaces.org/ papers/Defining_Blended_Learning_NF.pdf.

5. Singh, H., Reed Ch. A White Paper: Achieving Success with Blended Learning // American Society for Training \& Development, March 2001.

6. Valiathan, P. Blended Learning Models // American Society for Training \& Development, 2002 [Электронный peсурс]. - Режим доступа: http://old.astd.org/LC/2002/0802_valiathan.htm.

7. Желнова, Е.В. 8 этапов смешанного обучения (обзор статьи Д. Пентер Missed Steps). [Электронный ресурс]. - Режим доступа: http://www.obs.ru/ interest/publ/?thread=57.

8. Rosett, A., Vaughan F. Blended learning // CEO Epic Group plc, 52 Old Steine, Brighton. — 2003. [Электронный ресурс]. - Режим доступа: http://www.obs.ru/interest/publ/?thread=57.

9. Костина, Е. В. Модель смешанного обучения (Blended Learning) и ее использование в преподавании иностранных языков// Известия высших учебных заведений. Серия: Гуманитарные науки. 2010. Т. 1. № 2. с. $141-144$. 


\title{
Применение ИТ на уроках русского языка в целях развития самостоятельного и творческого мышления учащихся
}

\author{
Мамедова Сабина Азеровна, учитель русского языка и литературы \\ МАОУ «СОШ № 1 с углубленным изучением отдельных предметов» М0 «Ахтубинский район» (Астраханская область)
}

C инонимом современного общества сегодня принято считать общество цивилизованное, подчиняющееся ряду процессов, одним из которых неизменно считается информатизация. Информатизация общества - это глобальный социальный процесс, суть которого состоит в том, что доминирующим видом деятельности в сфере общественного производства является сбор, накопление, продуцирование, обработка, хранение, передача и использование информации, осуществляемые на основе современных видов техники, а также на базе различных способов информационного обмена.

Информатизация общества направлена на

- расширение познавательного потенциала человека;

- интеллектуализацию трудовой деятельности;

- интеграцию информационных технологий

с научными.

Применение открытых информационных систем, рассчитанных на использование всего объёма информации, доступной в данный момент обществу в определенной его сфере, позволяет усовершенствовать механизмы управления общественным устройством, способствует гуманизации и демократизации общества, повышает уровень благосостояния его членов. Процессы, происходящие в связи с информатизацией общества, способствуют не только ускорению научно-технического прогресса, интеллектуализации всех видов человеческой деятельности, но и созданию качественно новой информационной среды социума, обеспечивающей развитие творческого потенциала индивида. Одним из приоритетных направлений процесса информатизации современного общества является информатизация образования - процесс обеспечения сферы образования методологией и практикой разработки и оптимального использования современных или ориентированных на реализацию психолого-педагогических целей обучения, воспитания. [4, с.7]

Однако стоит отметить тот факт, что основа понятия ИТ не является принципиально новым положением. Работа с информацией как объектом исследования на уроке в образовательном процессе осуществлялась всегда. На основе взаимодействия с ней (самостоятельного/по заданному образцу/совместно с учителем) выделяется ряд принципов обучения, педагогических технологий, целей и задач урока. В связи с этим следует отметить, что под современными ИТ стоит понимать компьютерные, телекоммуникационные технологии. Использование мультимедийных средств связи позволяет сделать процесс обучения более мобильным, дифференцированным, творческим и индивидуальным.

Возросшая потребность во включении мультимедиа-технологий в процесс образования продиктована в том числе и положениями Федерального государственного стандарта среднего общего образования.

Так, обратившись к вышеупомянутому документу, мы встречаем ряд требований, связанных с готовностью выпускника соответствовать образу полноценного участника информационно-коммуникативной среды. Причем данная цель реализуются посредством взаимодействия всех основных членов образовательного процесса, а именно: к образовательному учреждению, к педагогическому работнику, к учащемуся. В следующей схеме отражены некоторые из положений ФГОС, связанные с ИТ и возможностями современной школы.

В настоящее время невозможно назвать дисциплину, в обучении которой так или иначе не применялись бы образовательные электронные ресурсы. Использование ИТ на уроках русского языка, к примеру, позволяет сделать урок не только более наглядным, но и помогает конкретизировать и анализировать предмет речи, развивает творческие возможности учащихся, способствует повышению качества их образования. При работе одновременно с несколькими текстами, анализе их жанровых или стилистических особенностей задача ученика заметно упрощается, если обратиться к таблицам, содержательной стороной которых являются цитаты из рассматриваемых произведений, схемам, их иллюстрирующим и т.д. В зависимости от возрастных и индивидуальных особенностей класса учитель может обращаться к аудио-, видеофайлам, соответствующим теме урока. Так, например, уместным и увлекательным станет обращение к мультипликационному фрагменту («В стране невыученных уроков», 1969) в рамках изучения темы «Правописание существительных с суффиксами -иик$u$-щцик-» (5 класс). А в 6 классе актуально обратиться, предположим, к аудиоматериалу - прослушиванию стихотворения Алексея Ерошина «Неграмотный пират», говоря о «Современных орфоэпических нормах».

Определенный этап психофизиологического развития учащихся задает свою частоту и вариативность применения средств ИТ, что также напрямую связано с особенностями осуществления методологической работы педагога, основывающейся на базовых принципах обучения.

Принцип сознательности и активности предполагает такой характер обучения, когда учащиеся не пассивно, путем зубрёжки и механических упражнений доводят свои навыки до автоматизма, а осознанно, глубоко и основательно усваивают определённые знания. А сознательность в обучении неразрывно связана с активностью учащегося, с его творчеством, что подводит нас к основам деятельностного подхода, где самостоятельное открытие нового знания является определяющим в продвижении развития. 


\begin{tabular}{|c|c|c|}
\hline \multicolumn{3}{|c|}{ Стаңдарт ориентирован на то, чтобы } \\
\hline 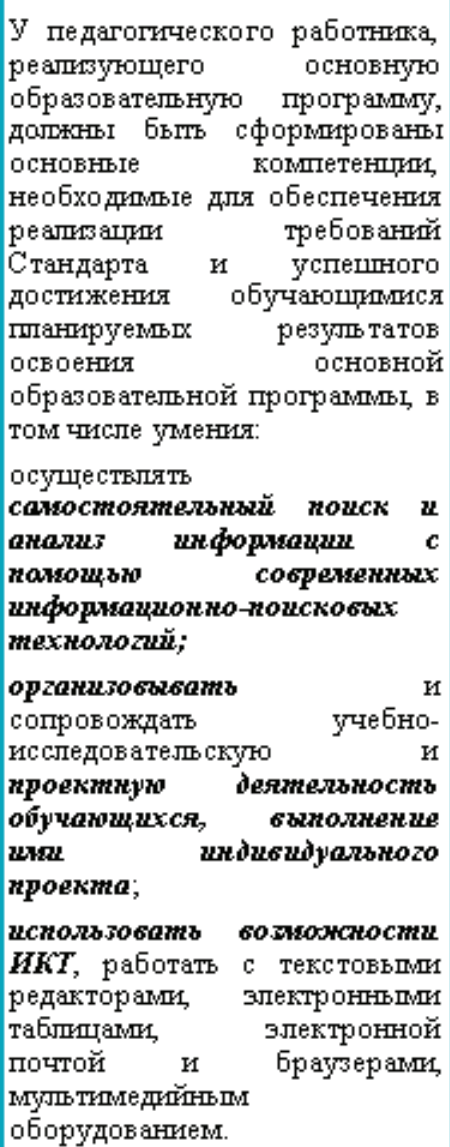 & 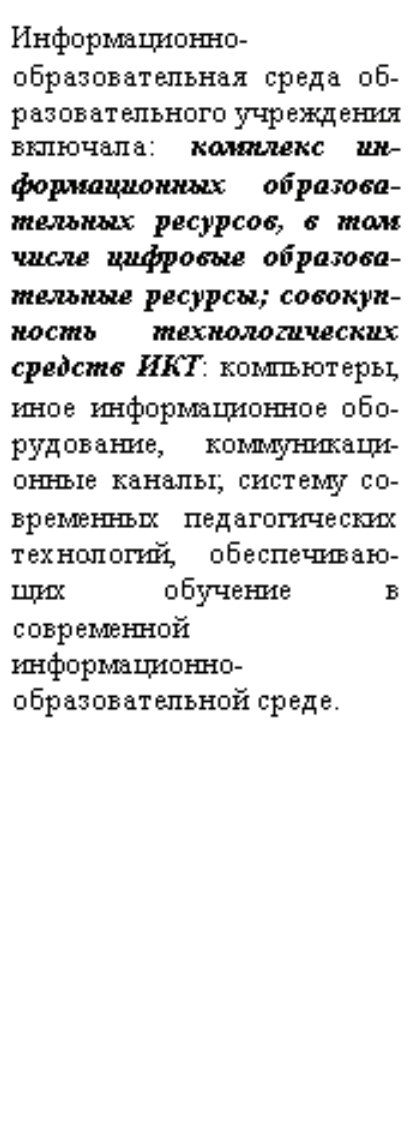 & 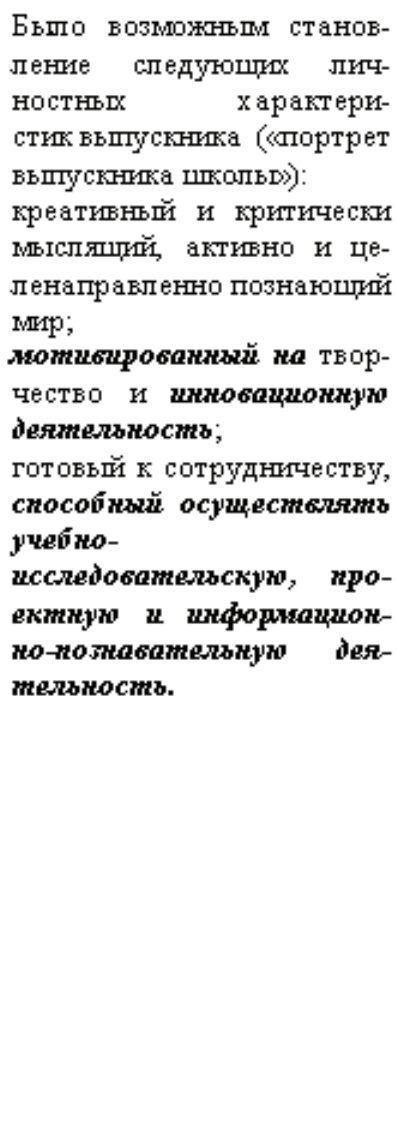 \\
\hline
\end{tabular}

Руководствуясь данным принципом, учитель может обратиться к следующим формам работы с применением ИТ: 1) опираясь на вопросы, представленные на слайде, придумайте и запишите свои, используя все глаголь из рамки. Напишите своё обтяснение, почему земляне видят только одну сторону Луны [6, с.39]; 2) просмотрите видеоролик, в котором представлень различные репродукции картин, посвящённые осени. Oпишите свои впечатления, используя как можно больше качественных прилагательных.

Принцип наглядности направлен в первую очередь на усвоение учащимися знаний путём непосредственного наблюдения за предметами и явлениями, процессами, происходящими внутри и вне изучаемого объекта путём чувственного восприятия. Ведь «ничего не может быть в сознании, что заранее не было дано в ощущении». Примерами заданий, в основу которых положен принцип наглядности, с применением ИТ: 1) прослушайте диалоги, в которых участвуют илены семьи Кузнецуовых. Как вы думаете, какой диалог происходит в формальной ситуации общения (официальной, деловой), а какой - в неформальной (дружеской, семейной)? Почему вы так решили? [6, с.60] 2) Просмотрите иллюстрации изучаемых фразеологизмов. Почему они кажутся комичными?
Принцип творчества (креативности) подразумевает работу ученика, стремящегося создать уникальный продукт - материал, работу, принадлежащую только ему, характеризующую его ход мыслей, рассуждения по заданной теме. Пример задания: после обращения к иллюстрациям/видеофрагментам по произведению К. Бульчёва попробуйте представить себе инопланетное животное. Как оно выглядит? Какие у него повадки? Опишите зверя из космического зоопарка, используя прилагательные и глаголь с не. [6, с.40]

«Современный ученик может по своему усмотрению иллюстрировать изучаемый текст, сделав его более личностным» [3, с.148]. Он может самостоятельно пересоздавать его: подвергать анализу, оставлять комментарии, пометы, отбирать необходимые аргументы, выстраивая базу для доказательств, отражающих его собственные идеи.

Е. С. Палат в своём труде указывает на тот факт, что мультимедийность создаёт психологические моменты, способствующие восприятию и запоминанию материала с использованием подсознательных реакций учащихся: например, подведение итогов или выдача заданий могут предваряться определённым звуком, слайдом или формой работы (зашифрованная в кроссворде/ребусе тема урока), настроив ребят на определённые эмоции. Это за- 
метно облегчает степень сосредоточенности учителя на данном этапе при дальнейшей работе.

Немаловажным будет отметить также роль и особенности самого педагога, выстраивающего свою деятельность с применением ИТ. Захарова И. Г. отмечает: «Для каждого педагога, будь то школьный учитель или вузовский преподаватель, главная цель - обеспечение качества образования, чему в большой степени может способствовать использование информационных и коммуникационных технологий». Признанный в мировом образовательном пространстве компетентностный подход к процессу обучения требует формирования следующих качеств специалиста: стремление постоянно обновлять свои профессиональные знания; готовность к активному участию в научно-исследовательской изобретательской, творческой деятельности.

Работа в области информатизации, включение в свою деятельность телекоммуникационных технологий требует особого склада мышления, характеризующегося точностью, обоснованностью, определённостью.
«Задача учителя состоит в том, чтобы информационно-коммуникативные технологии органично вплетались в деятельность учителя и стали неотъемлемой частью любого урока» [1].

Таким образом, рассмотрение и анализ конкретных примеров работы с ИТ на уроке показал, что компьютерные телекоммуникации способствуют созданию уникальной учебно-познавательной среды, т.е. среды, используемой для решения различных дидактических задач, направленных на развитие самостоятельного и творческого мышления учащихся. Такая среда характеризуется рядом свойств: возможностью обучать ребят навыкам грамотного говорения, правописания; наличием условий для развития творческого мышления; условиями для превращения обучения посредством телекоммуникационной сети в социальный процесс; концентрацией внимания всех участников взаимодействия на самой информации; расширения возможностей группового и проектного обучения.

Литература:

1. Данилова, Е. В. Использование информационно-коммуникационных технологий в современном образовательном процессе. Материалы Интернет-конференции «Современный преподаватель: личность и деятельность». (http://unid.bsu.edu.ru/unid/teach/sbornik)

2. Захарова, И.Г. Информационные технологии в образовании: Учеб. пособие для студ. высш. пед. учеб, заведений. - М.: Издательский центр «Академия», 2003. - 192 с.

3. Полат, Е.С. Новые педагогические и информационные технологии в системе образования: Учеб. пособие для студ. пед. вузов и системы повыш. квалиф. пед. кадров / Е. С. Полат, М. Ю. Бухаркина, М. В. Моисеева, А. Е. Петров; Под ред. Е. С. Полат. - М.: Издательский центр «Академия», 1999. - 224 с.

4. Роберт, И.В. Современные информационные технологии в образовании: дидактические проблемы; перспективы использования. - М.: ИИО РАО, 2010. - 140 с.

5. Федеральный государственный образовательный стандарт среднего (полного) общего образования (минобрнауки.рф/документы/2365)

6. Шмелёв, А. Д. Русский язык: 6 класс: учебник для общеобразовательных учреждений: в 2 ч. Ч. 1 / [А. Д. Шмелёв, Э.А. Флоренская, И. В. Пешков, Е. Я. Шмелёва]; под ред. А. Д. Шмелёва. - М.: Вентана-Граф, 2013. — 288 с.: ил.

\section{Развитие самостоятельности в процессе обучения иностранному языку в неязыковом вузе}

Маркова Наталия Александровна, преподаватель

Национальный исследовательский Томский политехнический университет

В статье раскрывается сущность самостоятельности в процессе обучения иностранным языкам, определяется ее место в учебном процессе. Раскрываются педагогические и методические технологии развития самостоятельности. Представлень видь работ, способствующие развитию самостоятельности в процессе обучения иностранному языку.

Ключевые слова: самостоятельность, обучение иностранному языку, неязыковой технический вуз, формирование навыков, учебный процзесс.

$\mathrm{P}$

звивающиеся международные экономические связи, предоставление предприятиям прав осуществлять

прямые контакты с зарубежными партнерами, проведение международных конференций, выставок, ярмарок привели 
к изменению социального заказа общества, что, в свою очередь, повлекло за собой трансформацию всей парадигмы высшего профессионального образования. В модели инженера международного уровня большее значение придается не только профессиональным знаниям и общему интеллектуальному развитию, но и языковой составляющей. Языковая подготовка в системе высшего профессионального образования должна обеспечивать развитие у обучающихся способностей, позволяющих использовать иностранный язык как инструмент общения в диалоге культур современного мира. В подтверждение этого обратимся к основополагающему для нас документу: «Требования к уровню владения иностранным языком студентов неязыковых специальностей национального исследовательского Томского политехнического университета», в котором определено, что программа языковой подготовки студентов неязыковых факультетов ТПУ нацелена на формирование и развитие автономности учебно-познавательной деятельности студента по овладению иностранным языком, предполагает учет личностных потребностей и интересов обучаемого. Процесс обучения строится на принципах сознательного партнерства и взаимодействия с преподавателем, что непосредственно связано с развитием самостоятельности студента, его творческой активности и личной ответственности за результативность обучения [1].

Очевидно, что одной из актуальных задач современной методики преподавания иностранного языка становится организация таких занятий, которые соответствовали бы новым требованиям. Изменения в программах обучения иностранным языкам обуславливают перспективы развития самостоятельности в языковой подготовке студентов в техническом вузе, а тенденции приближения образовательного уровня нашей страны к европейскому стандарту (многоуровневой системе) определяют вопрос важности развития самостоятельности. Имея задачу выхода в международное образовательное пространство (учеба в зарубежном вузе или на курсах зарубежных специалистов), студенты приобретают мотив, побуждающий их стремиться к более совершенному владению иностранным языком.

Не вызывает сомнения тот факт, что изучение иностранного языка всегда требует довольно большого количества времени, усилий и собственного желания и активного сознания самого «обучаемого». Ведь знания, приобретенные человеком благодаря своему стремлению и старанию, остаются в памяти на долговременный срок. Таким образом, самостоятельное обучение - важный аспект в освоении иностранного языка.

В неязыковых технических вузах, где иностранный язык выступает как непрофилирующая дисциплина, фактор мотивации - системы мотивов, побуждающих изучать язык, имеет огромное значение и представляется особенно важным. Именно интерес к получению новых знаний, готовность студента к самостоятельной организации учебной работы развивают мотивацию обучения. Таким образом, закономерно обозначена проблема раз- вития самостоятельности в процессе обучения иностранному языку в неязыковом вузе.

Под самостоятельностью понимается умение работать целенаправленно и по плану, выбирать наиболее рациональные приемы учебного труда, правильно рассчитывать свои силы и учитывать результаты собственной деятельности [2]. Самостоятельность предполагает сформированность навыков саморегуляции, которые позволяют оценивать результаты своих действий и при необходимости корректировать их. Немаловажную роль играет умение распределять усилия при достижении цели.

Продуктивность учебно-воспитательного процесса станет выше только в том случае, если преподаватель хорошо себе представляет и понимает психологические основы развития самостоятельности, связанные с психологической готовностью студентов к реализации своих действий в самостоятельной учебной работе. Актуальность развития самостоятельности определяет изменение содержания и формы учебного процесса. При формировании навыков самостоятельности, кроме развития инициативы и мышления, необходимо помнить об объяснении студентам важности и значимости саморазвития и самоподготовки в будущей профессиональной деятельности.

Развитие самостоятельности никоим образом не должно редуцировать роль и функции преподавателя; именно педагог организует такую учебную деятельность студентов, в которой познавательный процесс связан с интересом и вниманием к результатам своего труда. Студент сможет самостоятельно организовать свой учебный процесс, если преподаватель окажет ему активную помощь. Овладеть системой самостоятельных действий возможно именно при соответствии требованиям и структуре учебных программ, конкретном инструктировании о целях и задачах работы, оснащении необходимыми техническими средствами. Именно поэтому преподаватель остается в «приоритете» образовательного процесса: при появлении трудностей студент обращается к преподавателю. Искусство преподавателя состоит в том, чтобы определить, при решении какой учебной задачи и на какой стадии методически целесообразно «вынести» исполнение функций преподавателя для того, чтобы создать условия достижения максимального эффекта развития самостоятельности. Формирование навыков самостоятельности происходит при выполнении самостоятельной работы студентов в учебной деятельности, которая фактически делится на аудиторную и внеаудиторную работу.

В теоретическом плане выделяется 3 направления деятельности в самостоятельной работе: познавательное, практическое и организационно - техническое [3]. Данное положение позволяет говорить о безграничных возможностях развития познавательной, учебной, творческой, организационной, исследовательской самостоятельности. Практика работы показывает, что в формировании навыков самостоятельности можно выделить несколько этапов: первый этап включает формиро- 
вание умений принимать и самостоятельно анализировать сообщение преподавателя в рамках учебного материала. На втором этапе формируют умения и навыки самостоятельной работы: студентам предлагают самостоятельно изучить, осмыслить новый учебный материал. Третий этап предполагает переработку материала и закрепление знаний, умений и навыков. На этом этапе студентам предлагают интерпретировать - передать изученный материал, используя приемы самоконтроля, например, при повторении или текущей проверке знаний - ответить на контрольные вопросы по содержанию материала или выполнить тестовые задания. Далее, студентов учат рационально использовать приемы самоконтроля и навыки поисковых действий в работе с дополнительными средствами обучения привлечением современных информационных технологий (студентов вовлекают в выполнение самостоятельной работы: проект, презентация, задания на платформе Moodle), которые обеспечивают развитие творческой самостоятельности [4]. Формирование принципа сознательности, как важной составляющей понятия «самостоятельность», при их выполнении становится необходимой ступенью обучения иностранному языку. И наконец, студентов учат самостоятельно решать проблему, находить конструктивные решения, выход из кризисной ситуации (решение ситуаций - кейсов). На этом этапе основными приемами развития самостоятельности являются подготовка доклада - сообщения к семинару, конференции, рецензирование или аннотирование научной статьи, проведение исследовательской работы.

Все эти этапы, реализованные через учебный процесс в разных учебно-организационных формах и методах, несомненно, будут способствовать развитию самостоятельности в процессе обучения иностранному языку и позволят применить развитые приемы самоконтроля для оценки качества усвоения полученного материала при подготовке к значимым итоговым результатам обучения - текущему, промежуточному и итоговому (экзамену, зачету) контролям. Таким образом, значимость развития самостоятельности в процессе обучения обоснована.

В процессе преподавания иностранного языка в неязыковом вузе особое значение развитие самостоятельности приобретает на начальном и среднем этапах обучения иностранному языку. Фактически, к систематическому развитию самостоятельности можно приступать уже в первом семестре обучения. Студенты продвинутого уровня владения иностранным языком, большей частью, высоко замотивированы, серьезно и устойчиво заинтересованы в получении знаний, а значит, самостоятельность в обучении у них приоритетна. Как правило, в технических неязыковых вузах обучение иностранному языку проходит в рамках продолжения школьного курса. Удовлетворить запросы студентов продвинутого уровня могут элективные курсы по иностранному языку, которые, чаще всего, соединяют в себе языковую и профессиональную подготовку по узкой специальности. Ведь именно подготовка высококвалифицированного специалиста того или иного профиля является актуальной задачей неязыковых технических вузов.

Одним из эффективных средств развития самостоятельности, используемых в процессе обучения на базовом курсе языковой подготовки в техническом вузе является широкое применение на занятии аутентичных видеокурсов на иностранном языке. Сюжеты видеокурсов создают проблемные речевые ситуации, дают ценный материал для обсуждений, дискуссий на занятиях, что существенно мотивирует иноязычную речевую деятельность студентов, а также способствует накоплению опыта речевого общения, который на определенной стадии (у разных студентов в разное время) обуславливает возможность и желание студента выйти на уровень самостоятельного участия в реальном общении, а значит расширить возможности развития самостоятельности в учебном процессе.

В связи с тем, что самостоятельная работа предполагает развитие внутренней и внешней самоорганизации будущего специалиста, его способность выстраивать индивидуальную траекторию самообучения, а также формировать способности к саморазвитию и творческому применению полученных знаний [5], внеаудиторное развитие самостоятельности студентов начального и среднего уровней владения иностранным языком происходит медленно. Им не хватает силы воли, умения, а главное желания планировать свою деятельность самостоятельно. В целом, организация учебного дня студента не становится предпосылкой формирования самостоятельности.

Тем не менее, в настоящее время развитие самостоятельности в процессе обучения иностранному языку приобретает все большее значение и становится естественным компонентом учебного процесса в неязыковом вузе. В целом, на наш взгляд, развитие самостоятельности - это один из путей интенсификации и повышения эффективности учебного процесса по иностранному языку. Он дает возможность изменить качество преподавания языка, позволяет значительно расширить языковые возможности студентов и стимулировать их интерес к занятиям, следовательно, должен обеспечить и более высокий уровень владения иноязычной речью у студентов неязыкового вуза, который позволит им интегрироваться в международную профессиональную и научную среду. А это значит, требования программы языковой подготовки студентов нелингвистических специальностей технического вуза выполняются.

\section{Литература:}

1. Петровская, Т.С., Прохорец, Е.К., Петрашова, Т.Г., Болсуновская, Л.М., Тарасова, Л.В., Ратнер, Л.С.. Требования к уровню владения иностранным языком студентов неязыковых специальностей Томского политехниче- 
ского университета. URL: http://portal.tpu.ru/SHARED/1/LENPRO/UR/Tab2/Lehrwerk.doc (дата обращения: 29.12.2014).

2. Коноводова, Ю.А. Актуальность самостоятельной работы школьников в образовательном процессе // Педагогика: традиции и инновации: материалы II междунар. науч. конф. - Челябинск: Два комсомольца, 2012.c. $105-106$.

3. Илюшин, Л. С. Образовательная мотивация: теория и методология исследования. URL: http://www.dissercat. $\mathrm{com} /$ content/metodologiya-i-metodika-kross-kulturnogo-issledovaniya-obrazovatelnoi-motivatsii-sovremennyk (дата обращения:18.01.15)

4. Кудряшова, А.В., Горбатова, Т.Н., Эффективность развития творческой самостоятельности студентов неязыковых вузов в процессе обучения иностранному языку Молодой ученый. - 2014. - № 21. — c. 641-643.

5. Абросимов, А.Г. Современные информационные технологии в организации самостоятельной и неаудиторной работы студентов вузов // Журнал «Вестник РУДН». 2004. № 1. с. 56

\title{
Организация проектной деятельности как средство развития исследовательских умений учащихся 7 класса на уроках биологии
}

\author{
Маскаева Анастасия Васильевна, студент \\ Научный руководитель: Барсукова Ирина Николаевна, ассистент \\ Хакасский государственный университет им. Н. Ф. Катанова (г. Абакан)
}

В статье рассматривается развитие исследовательских умений учащихся через организацию проектной деятельности на уроках биологии в 7 классе и выявление условий их реализации через модель изучения темы «рьбы»

Ключевые слова: исследовательские умения, проект, проектная деятельность

A ктуальность исследования подтверждена ФГОС второго поколения (2010), в которых прописывается, что личностные и метапредметные результаты должны быть направлены на формирование у обучающихся основ культуры исследовательской и проектной деятельности, навыков разработки, реализации и общественной презентации обучающимися результатов исследования, предметного и межпредметного учебного проекта.

Под исследовательскими умениями мы будем понимать интеллектуальные и практические умения, обусловленные самостоятельным выбором и применением приёмов и методов исследования на доступном детям материале [1].

Исследовательские умения можно развивать с помощью информационно-коммуникационных, игровых, проектных, модульных технологий, технологий проблемного обучения, обучение развития критического мышления, но мною решеноиспользовать именно проектные технологии, так как метод проектов, по мнению Г.Л. Ильина [2], это «способ достижения дидактической цели через детальную разработку проблемы, которая должна завершиться вполне реальным, осязаемым практическим результатом».

Анализ литературы показал, что в теории проблема развития исследовательских умений развита достаточно полно.

Однако, беседа с директором и психологом школы показали, что в данной школе дети не обладают достаточным уровнем исследовательских умений, а также анкетиро- вание учителей подтвердили наличие проблемы в этой школе: недостаточный уровень развития исследовательских умений учащихся.

Цель исследования: разработать и апробировать модель изучения темы «Рыбы» (Биология, 7 класс), направленную на развитие исследовательских умений учащихся через организацию проектной деятельности на уроках биологии и выявить условия ее реализации.

Объект исследования: исследовательские умения учащихся основной школы.

Предмет исследования: проектная деятельность как средство развития исследовательских умений учащихся 7 класса на уроках биологии.

Гипотеза: развитие исследовательских умений учащихся 7 класса будет более эффективным при изучении темы «Рыбы» (Биология, 7 класс), если:

будут учтены индивидуальные особенности личности каждого ученика;

учащихся распределить на группы, учитывая уровень развития исследовательских умений каждого ученика;

на занятиях использовать задания разного уровня сложности, учитывая уровень каждой группы учащихся;

использовать проектные технологии;

Задачи:

1. Изучить состояние проблемы развития исследовательских умений в теории педагогической науки и в практике современной школы; 
2. Подобрать диагностики для определения уровня развития исследовательских умений у учащихся;

3. Разработать и апробировать модель изучения темы «Рыбы», направленную на развитие исследовательских умений учащихся через организацию проектной деятельности на уроках биологии;

4. Выявить условия реализации модели изучения темы «Рыбы» (Биология, 7 класс), направленной на развитие исследовательских уменийчерез организацию проектной деятельности на уроках биологии.

Теоретическая значимость работы:

1. Выявленные педагогические условия процесса организации исследовательской деятельности учащихся основной школы научно обоснованы, важнейшими условиями можно считать индивидуальные особенности учащихся при формировании ученических групп, разработка и использование средств дидактического обеспечения процесса развития исследовательских умений учащихся.

2. Теоретически обоснована структурно-содержательная модель организации исследовательской деятельности учащихся основой школы.

Практическая значимость работы:

Предложены эффективные формы и методы процесса организации исследовательской деятельности учащихся при изучении темы «Рыбы» (Биология. 7 класс), используя исследовательский метод и метод проектов.

Для данного исследования мною были использованы, методы, предложенные В.А. Сластениным [3].

\section{Результаты исследования}

Исследование проводилось в седьмом классе МОБУ Нижнекужебарская СОШ села Нижний Кужебар Каратузского района Красноярского края. На констатирующем этапе было проведено анкетирование учителей, в котором приняли участие восемь педагогов школы. Анкета состояла из 7 вопросов и была анонимной. Все педагоги единогласно ответили, что развивать исследовательские умения необходимо и что уровень исследовательских умений у большинства учеников седьмого класса средний. Половина педагогов ( 50 \% ) чаще всего для развития исследовательских умений использует информационно-комму- никативные технологии, два педагога (25\%) - игровые, один педагог $(12,5 \%)$ - технологию проблемного обучения и лишь один педагог ( $12,5 \%$ ) для развития исследовательских умений использует метод проектов. Согласно данным анкетирования, педагоги считают, что использование метода проектов эффективно для развития исследовательских умений. Шесть педагогов (75\%), считают, что все исследовательские умения прекрасно развиваются при использовании проектных технологий, два педагога (20\%) пришли к выводу, что наилучшим образом данный метод обеспечивает формирование умения работать с первоисточниками, а также анализировать сравнивать и делать выводы и два педагога (20\%) решили, что наилучшим образом развивается умение проводить эксперимент, делать выводы и анализировать. В 7 классе обучаются семь учеников, пять девочек и два мальчика, все дети увлекающиеся, имеющие широкий круг интересов, заняты дополнительным образованием, в том числе и в детском объединении эколого-географической направленности «Юный исследователь».

Диагностирование учащихся проведено по двум диагностикам:

Определение поисковой активности учащихся с помощью карт наблюдения. Қак отмечает Самохина Е.Ю. [4]. поисковая активность является первоисточником и основным двигателем исследовательского поведения. Стремление к поисковой активности, с одной стороны - предопределено биологически, а с другой стороны - это качество развивается под воздействием среды. На наличие поисковой активности указывают такие необходимые составляющие исследовательского поведения как высокая мотивация, интерес, эмоциональная включенность. Именно поэтому была выбрана данная диагностика.

Тест креативности Е.П. Торранса (склонность к $\partial и-$ вергентному мышлению). Способность и склонность к дивергентному мышлениюявляется качеством, необходимым в ситуациях исследовательского поведения также отмечает Самохина Е. Ю [5].

Результаты диагностирования на констатирующем этапе опытно-экспериментальной работы представлены в табл. 1.

Таблица 1. Результаты диагностирования учащихся 7 класса МоБу Нижнекужебарская Сош на констатирующем этапе опытно-экспериментальной работы

\begin{tabular}{|c|c|c|c|}
\hline \multirow[t]{2}{*}{ Название диагностики } & \multicolumn{3}{|c|}{ Уровень исследовательских умений 7 класса } \\
\hline & низкий & средний & высокий \\
\hline \multicolumn{4}{|c|}{ 1. Карта наблюдения. Поисковая активность } \\
\hline & 1чел. $(14 \%)$ & чел. $(29 \%)$ & 4 чел. (57\%) \\
\hline \multicolumn{4}{|c|}{ 2. Тест креативности Е. П. Торранса (склонность к дивергентному мыиилению) } \\
\hline А) Беглость мышления & 2 чел. (29\%) & 2чел. (29\%) & 3 чел. (42\%) \\
\hline Б) Гибкость мышления & 2 чел. (29\%) & 2 чел. (29\%) & 3 чел. $(42 \%)$ \\
\hline В) Оригинальность мышления & 2 чел. (29\%) & 2 чел. (29\%) & 3 чел. (42\%) \\
\hline
\end{tabular}




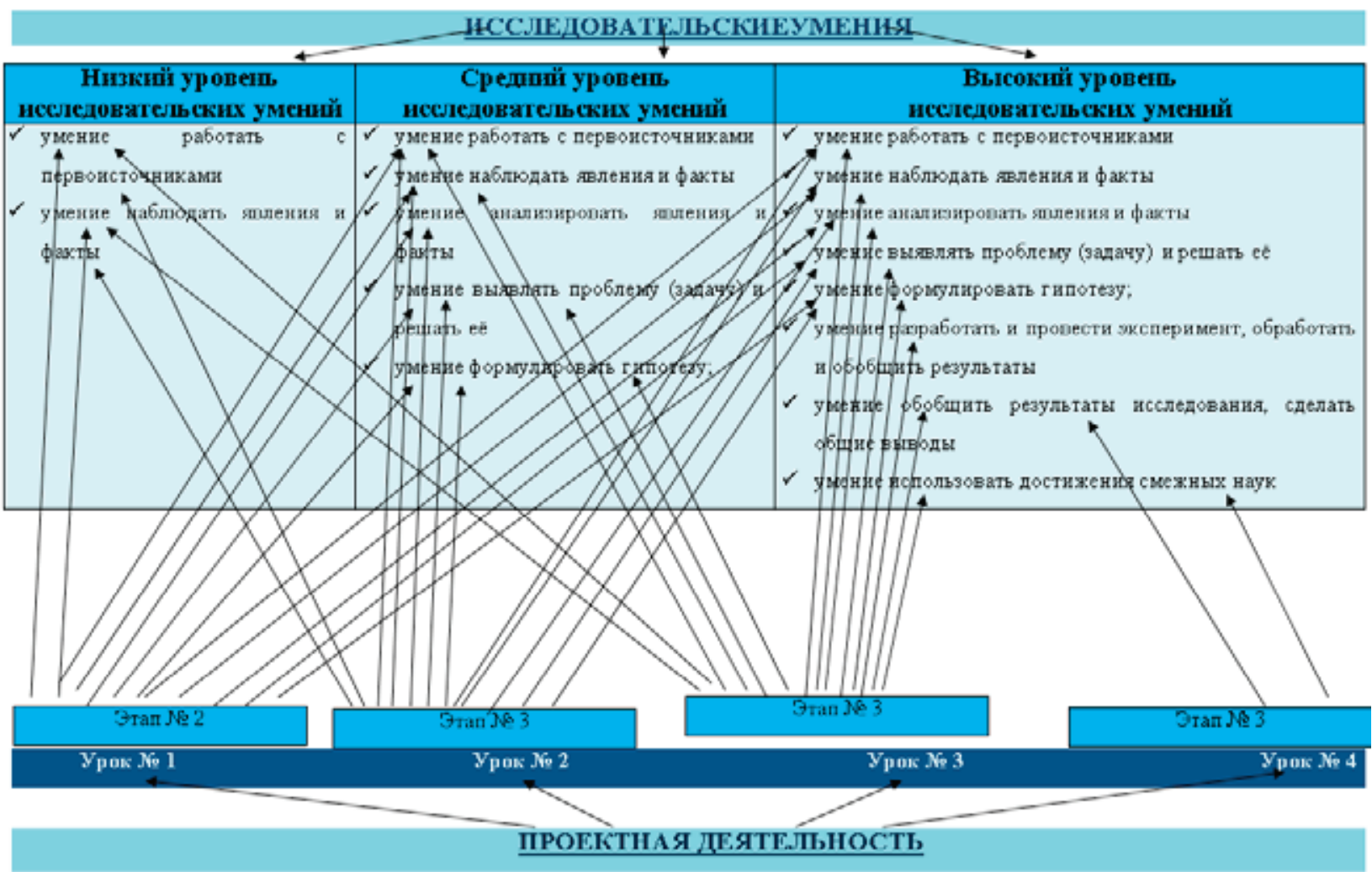

\section{Рис. 1. Модель изучения темы «Рыбы», направленная на развитие исследовательских умений учащихся через организацию проектной деятельности на уроках биологии}

Анализ таблицы показал, что по первой диагностикеиз семи учащихся четыре имеют высокий уровень активности, два ученика имеют средний уровень и один низкий уровень. Согласно результатам, второй проведенной стартовой диагностики высокий уровень по показателю «Беглость - суммарное число ответов» имеют пять учеников, один ученик имеет средний уровень и один ученик имеет низкий уровень по данному показателю.Высокий уровень по показателю «Гибкость - числокатегорий ответов» имеют три ученика, два ученика имеет средний уровень и два ученика имеет низкий уровень по данному показателю. По показателю «Оригинальность - число необычных, оригинальных ответов» результат идентичен с прошлым показателем: три ученика имеют высокий показатель, два ученика средний и два ученика низкий.

Согласно мнению Г. В Мухамадияровой [6], у учащихся каждого уровня сформированы определенные группы исследовательских умений. В связи с этим модель должна четко отражать, какой уровень, на каком уроке и с помощью какого проектного задания будет развиваться. В связи с этим нами была разработана модель изучения темы «Рыбы», которая представляет собой схематичное отображение развития исследовательских умений у учащихся седьмого класса через проектную деятельность.

Для реализации поставленной цели мною была составлена и использована в практике МОБУ Нижнекужебарская СОШ в седьмом классе методическая разработка изучения темы «Рыбы», состоящая из четырех уроков, для разработки использовалась проектная технология. Қаждый урок являлся этапом реализации общего проекта. При составлении планов-конспектов уроков учитывались индивидуальные особенности развития каждого ученика, класс был разделен на три группы, в зависимости от уровня развития исследовательских умений, для чего заранее были проведены специальные диагностики, задания были разного уровня сложности.

\section{План распределения уроков}

\begin{tabular}{|l|l|}
\hline \multicolumn{1}{|c|}{\begin{tabular}{c}
\multicolumn{1}{|c|}{ Этапы. } \\
№ урока
\end{tabular}} & \multicolumn{1}{c|}{ Приемы и методы } \\
\hline $\begin{array}{l}\text { Урок первый } \\
\text { Выбор темы проектного задания с учетом } \\
\text { анализа потребностей, интересов уча- } \\
\text { щихся, школы и особенностей региона. } \\
\text { Подбор необходимой литературы. }\end{array}$ & $\begin{array}{l}\text { Кообщение учителя. } \\
\text { Краткое и четкое определение проблемы. } \\
\text { Ограничивающие факторы (стоимость, время, оборудование) } \\
\text { Выбор источников информации: литература, выставки, интернет, учеб- } \\
\text { ники, информационные центры и т.д.; }\end{array}$ \\
\hline
\end{tabular}




\begin{tabular}{|c|c|}
\hline $\begin{array}{l}\text { Урок второй } \\
\text { Разработка проекта: } \\
\text { 1.Исследование. } \\
\text { 2.Развитие идеи. } \\
\text { 3.Планирование. }\end{array}$ & $\begin{array}{l}\text { После сбора необходимой информации наступает этап развития соб- } \\
\text { ственных идей. Поиск оптимального варианта. } \\
\text { Составление расписания работы, выделение ее этапов, выбор формы } \\
\text { предъявления информации. }\end{array}$ \\
\hline $\begin{array}{l}\text { Урок третий } \\
\text { Выполнение проекта. }\end{array}$ & $\begin{array}{l}\text { Подготовка оборудования, проведение проекта с учетом техники безо- } \\
\text { пасности. } \\
\text { Самоанализ, представление результата обсуждения, заключение. }\end{array}$ \\
\hline $\begin{array}{l}\text { Урок четвертый } \\
\text { Оценка качества выполненной работы } \\
\text { (своей и чужой), защита проекта. }\end{array}$ & Защита проекта \\
\hline
\end{tabular}

На первом уроке, одно из главных умений, которое должно развиваться у учащихся - это умение работать с первоисточниками, что и реализуется на втором этапе урока, как и отмечено в плане - конспекте, детям, учитель выявляет проблему, для её решения должна быть определена гипотеза. Далее для учащихся был предложен широкий спектр источников информации, но чтобы разобраться в таком потоке информации необходимо наблюдать, выделят главное, анализировать, таким образом, на данном этапе развиваются и другие исследовательские умения, что отражено в модели изучения темы.

На втором уроке осуществлялся сбор материала по теме, наиболее интересен третий этап, каждой группе выдавалась инструктивная карточка, с заданиями, соответствующими их уровню развития исследовательских умений, ученики, используя весь спектр источников информации, включая отобранный ранее, находят ответы на поставленные вопросы, и оформляют полученные результаты согласно плану. Инструктивные карточки представлены в плане-конспекте второго урока (Приложение Д). Работа с инструктивными карточками предполагает развитие большого спектра исследовательских умений школьников (умение работать с первоисточниками, умение наблюдать явления и факты, умение анализировать явления и факты, умение выявлять проблему (задачу) и решать её, умение формулировать гипотезу), для ребят с низким уровнем исследовательских умений предполагается значительная помощь учителя, что и показано на модели изучения темы.

Третий урок предполагает разработку и оформление проекта, на третьем этапе урока. Перед учащимися трех групп, ставится проблема, соответствующая уровню развития их исследовательских умений, каждая группа разрабатывает свой проект: «Экология рыб» группой «Экологи», «А как же устроена рыбка золотая?» группой «Анатомы», «Как функционирует организм представителей надкласса Рыб» группой «Физиологи», итоговый проект будет представлен в виде электронной презентации, с разной степенью сложности, учитывая уровень каждой группы и каждого ученика в отдельности. Подготовка проекта идет по плану, прописанному в инструктивных карточках. Данный урок, кроме описанных ранее умений развивает также умение, обрабатывать и обоб- щать результаты своего исследования, делать общие выводы, через обобщение результатов своего труда и умение использовать достижения смежных наук, в частности оформление электронной презентации требует знаний, умений и навыков в области информатики.

Четвертый урок является заключительным и наиболее интересен учащимся, так как дети презентуют результаты своего труда, сравнивают и анализируют, делают выводы. Урок был проведен в виде «Фестиваля проектов», где все выступления групп были обобщены в виде единого проекта изучения «Надкласса Рыбы».

\section{Контролирующий этап}

После выполнения проекта по теме «Рыбы», нами проведена повторная диагностика, с целью определения динамики изменения уровня исследовательских умений экспериментального класса, для чего учащимся было предложено выполнить повторно диагностику «Тест креативности Е.П. Торранса» на определение уровня дивергентного мышления, а также педагогам было предложено оценить повторно уровень познавательной активности учащихся седьмого класса с помощью карт наблюдения.

Согласно данным, по всем показателям наблюдается положительная динамика изменения уровня исследовательских умений учеников экспериментального 7 класса. Динамика изменения уровня исследовательских умений представлена на рисунке 2.

На диаграмме видно, что у одного ученика повысился уровень исследовательских умений до высокого, хотя до этого его уровень соответствовал среднему. Два ученика повысили свой уровень до среднего. Рисунок 3 отображает изменение уровня дивергентного мышления по показателю «беглость мышления», в данном случае один ученик повысил свой уровень со среднего до высокого, и один с низкого до среднего.

Склонность к дивергентному мышлению по показателю «гибкость мышления» отражена на диаграмме рисунка 4.

На данной диаграмме видно, что один ученик улучшил свои исследовательские умения и перешел с низкого уровня на средний и один ученик со среднего на высокий. 


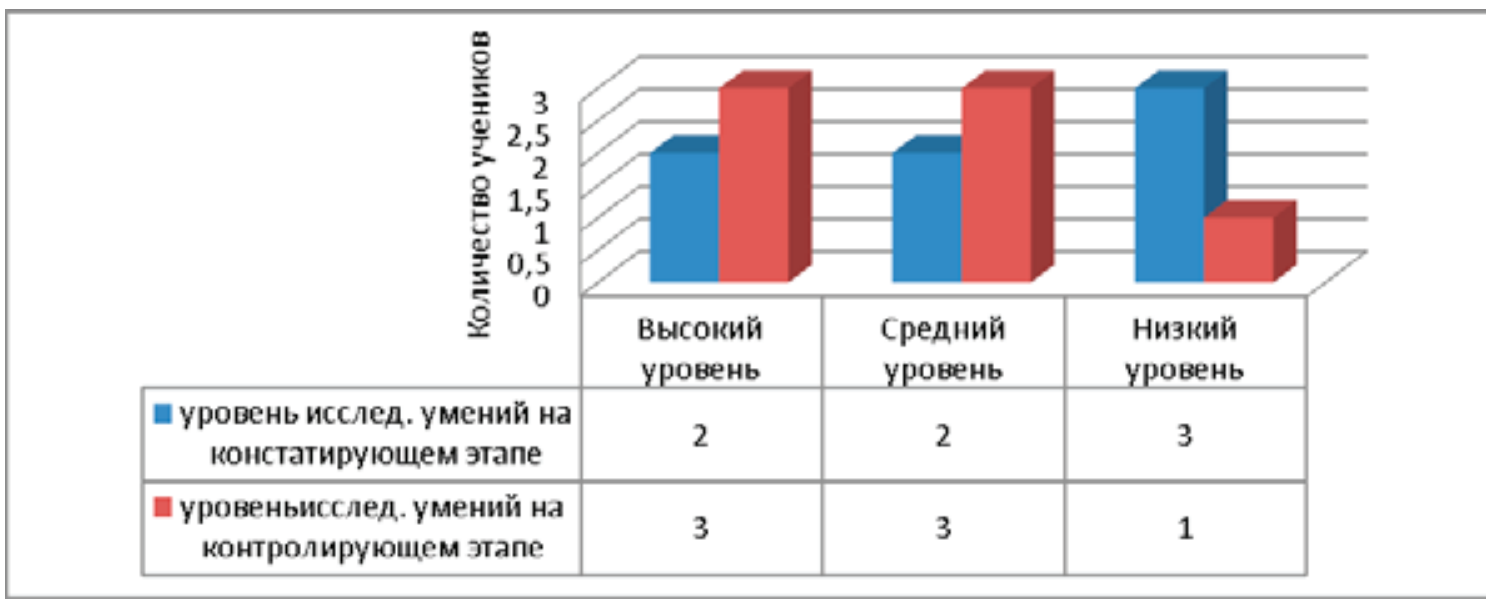

Рис. 2. Динамика изменения исследовательских умений испытуемого 7 класса

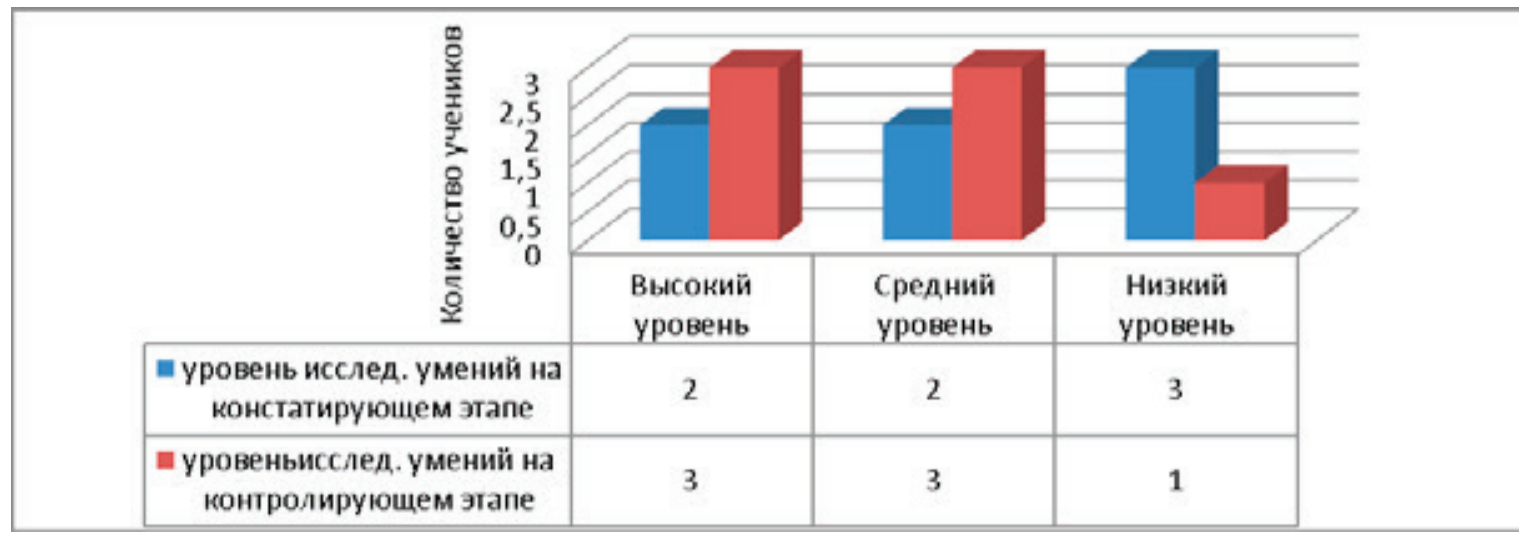

Рис. 3. Динамика изменения уровня склонности к дивергентному мышлению (беглость) в испытуемом 7 классе

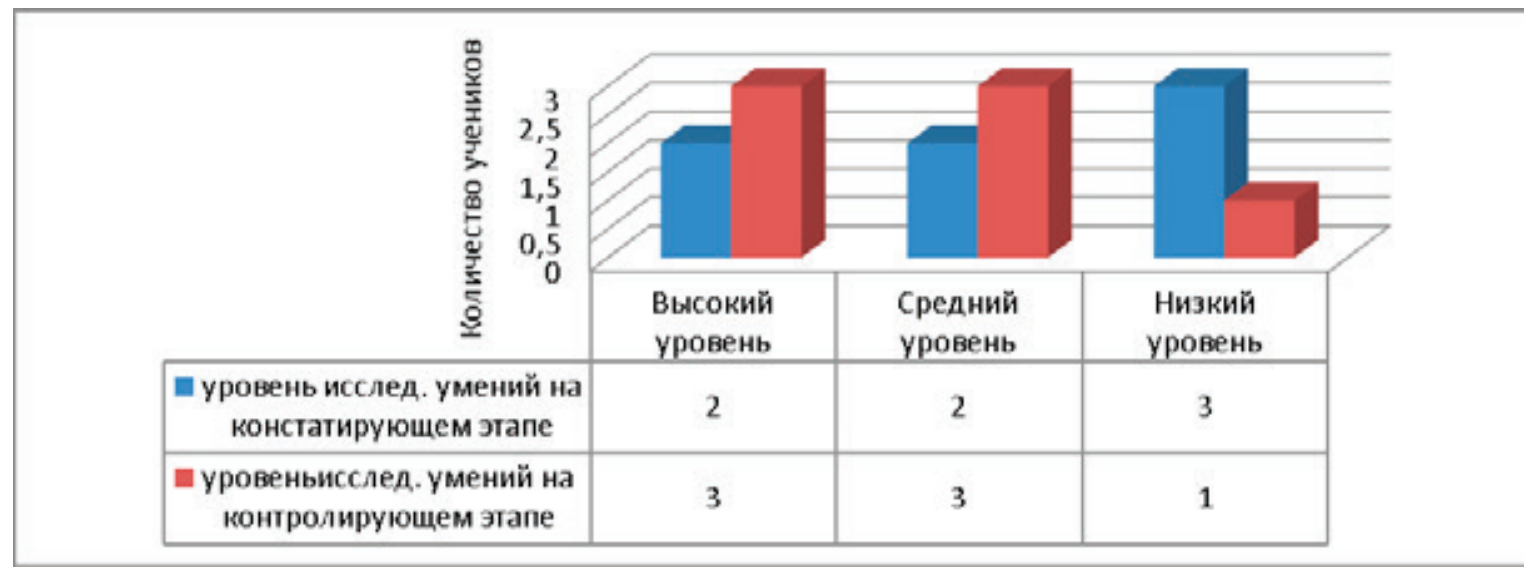

Рис. 4. Динамика изменения уровня склонности к дивергентному мышлению (гибкость) в испытуемом 7 классе

Подобное соотношение обнаружено и для показателя «оригинальность мышления», что представлено на рисунке 5.

Таким образом, можно констатировать тот факт, что по всем показателям наблюдается положительная динамика изменения уровня исследовательских умений учащихся экспериментального седьмого класса МОБУ Нижнекужебарская СОШ.

\section{Выводы}

1. Изучено состояние проблемы развития исследовательских умений в теории педагогической науки и в практике современной школы.

2. Подобраны и проведены диагностики определения уровня развития исследовательских умений учащихся на 


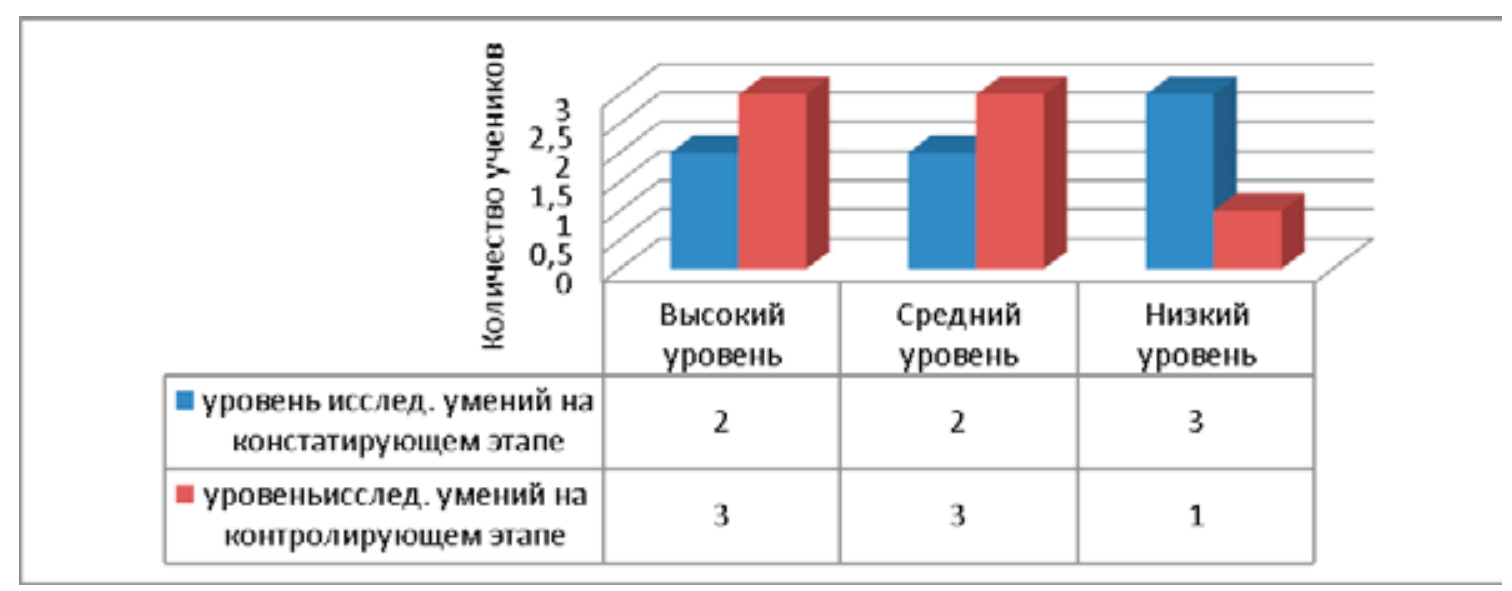

Рис. 5. Динамика изменения уровня склонности к дивергентному мышлению (оригинальность) в испытуемом 7 классе

констатирующем и контролирующем этапах исследования, выявлена положительная динамика изменения по всем показателям уровня исследовательских умений: «Поисковая активность», «Склонность к дивергентному мышлению»

3. Разработана и апробирована модель изучения темы «Рыбы», направленная на развитие исследовательских умений учащихся через организацию проектной деятельности на уроках биологии.

4. Выявлены условия реализации модели изучения темы «Рыбы» (Биология, 7 класс), направленной на раз- витие исследовательских умений через организацию проектной деятельности на уроках биологии:

- Учет особенностей личности каждого ученика;

- Распределение на группы, учитывая уровень развития исследовательских умений учащихся;

- Использование заданий разного уровня сложности, учитывая уровень каждой группы;

- Использование проектных технологий.

Литература:

1. Обухов, А. С. Исследовательская деятельность как возможный путь вхождения подростков в пространство культуры Текст. / А. С. Обухов // Развитие исследовательской деятельности учащихся: метод, сб. - М., 2001. с. 48 -64.

2. Ильин, Г.Л. Теоретические основы проективного образования: дисс.. д. пед. наук / Г.Л. Ильин. Казань, 1995. - 38 c.

3. Сластенин, В.А. Педагогика: учебное пособие для студентов высших педагогических учебных заведений Текст. / В.А. Сластенин, И.Ф. Исаев, Е. Н. Шиянов; под ред. В.А. Сластенина. 2-е изд., стереотип. - М.: Академия, 2003. - 236 c.I

4. Самохина, Е. Ю. Формирование исследовательских умений у студентов профессионально-технического колледжа на занятиях по информатике. Автореф. дис. ... канд. педаг. наук. М.: МГПУ, 2012. 26 с.

5. Мухамадиярова, Г. В. Исследовательская культура учащихся: путиразвития. Казань, 2007

\section{Особенности работы над лексикой в процессе преподавания иностранного языка в вузе}

Милотаева Ольга Сергеевна, кандидат филологических наук, доцент Пензенский государственный университет архитектуры и строительства

Данная статья посвящена рассмотрению особенностей работы над иноязычной лексикой. В процессе преподавания иностранного языка необходимо работать над словообразованием, изучать возможности сочетаемости слов и фразеологических единиц, а также уделять внимание употреблению слов в переносном значении.

Ключевые слова: лексика, словообразование, фразеологическая единица, сочетаемость слов, прочесс обучения, иностранный язык. 
$\mathrm{H}^{2}$ а занятиях по иностранному языку в вузе продолжается работа над словом в пределах многозначности, омонимии, синонимии и антонимии. Высокие интеллектуальные возможности студентов, хорошая их подготовка по родному языку, а также лучшее понимание закономерностей развития языка позволяют усилить работу над лексикой в вузе.

У учащихся уже накоплен значительный словарный запас, который служит отличной базой для более углубленной работы над смысловой структурой слова. Содержанием этой работы будет изучение словообразования, сочетаемости слов и фразеологических единиц и употребление слов в переносном значении.

При овладении любым иностранным языком, в частности, английским, большое значение имеет работа над словообразованием. Суффиксация представляет значительно больший интерес, чем префиксация. Число префиксов в английском языке невелико и каждый имеет вполне определенное значение. Изучение суффиксального способа словообразования следует начинать как можно раньше и такая работа должна осуществляться постоянно в процессе обучения иностранному языку, так как целью работы над суффиксами является расширение словарного запаса учащихся Основными упражнениями можно назвать следующие:

1. Анализ производных слов, состоящих из непроизводной основы и суффикса при знакомой непроизвольной основе. Целью таких упражнений должно быть развитие умений видеть производное слово.

2. Упражнения на омонимию суффиксов. Подобные упражнения необходимы для показа того, что производные слова, оформленные суффиксами-омонимами в большинстве случаев относятся к разным частям речи, а также для установления места производного слова в предложении, оформленности данного слова служебными словами для того, чтобы определить относятся ли анализируемые слова в данными суффиксами-омонимами к различным частям речи и к каким именно или с их помощью образуются разные формы одних и тех же слов. Например, суффикс -al является суффиксов абстрактных имен существительных, обозначающих действие, состояние, качество, и в то же время является суффиксом имен прилагательных. Суффикс -er, присоединенный к глаголу, образует другую часть речи - существительное. а присоединенный к прилагательному. образует сравнительную его степень.

3. Упражнения на определение исходной части речи производного слова путем отбрасывания словообразовательных суффиксов.

4. Упражнения, направленные на правильное произношение производных слов с изучаемыми суффиксами. Необходимо обращать внимание на место ударения в слове и на произношение суффиксов.

5. Упражнения, направленные на правильное отнесение производного слова к определенной части речи или к формам одного и того же слова по суффиксу и на правильный перевод производных слов на русский язык. [3, c.230]
K наиболее употребительным суффиксам-омонимам относятся:

1. Суффиксы имен существительных и имен прилагательных -al, - ant, - ent;

2. Суффикс имен прилагательных и глаголов -ish;

3. Суффикс глаголов, имен прилагательных и некоторых имен существительных во множественном числе -en;

4. Суффикс имен прилагательных и наречий -ly.

Работа над суффиксальной омонимией дополнительно повышает практический эффект владения списком минимумом суффиксов. [1, с.50]

Говоря о сочетаемости слов, следует иметь в виду их смысловую сочетаемость, то есть сочетаемость слов в их номинативном значении. Нормы родного языка зачастую мешают правильному пониманию таких словосочетаний как hard winter - суровая зима или heavy play - скучная пьеса, которые русский учащийся, как правило, переводит как тяжелая зима и тяжелая пьеса. Поэтому для правильного понимания сочетания слов в тексте необходимо знать способность слова к сочетанию с другими словами, так как слова в разных языках сочетаются по-разному. В этом проявляются определенные внутренние закономерности развития объема значений слова в данном языке, а также принцип избирательности в языке. [4, с.115]

Работа над сочетаниями слов должна начинаться с их накапливания. Следует применять специальные упражнения на сочетаемость слов:

- перевод с английского языка предложений, в которые были бы включены сочетания определенных слов;

- установление преобладающего значения данного английского слова, употребляемого в сочетании с другими словами;

- выборка из большой группы слов тех, которые сочетаются с указанным словом;

- самостоятельное написание сочетаний данного при лагательного или данного глагола с существительными;

- анализ внутренней связи оттенков значений данного английского слова, употребляемого в сочетании с другими словами;

- анализ сочетаний с данным словом в английском языке и соответствующих им русских сочетаний;

- заучивание необходимых сочетаний;

- перевод с русского языка на английский специально составленных небольших текстов.

Работа над переносным значением слова должна привлечь внимание преподавателя, так как она является углублением работы над многозначностью слова, учит правильному восприятию языкового материала на родном и иностранном языках. Овладение явлением переноса значения слова имеет огромное общеобразовательное значение. В иностранном языке затруднения в понимании или ошибочное решение вопроса иногда обусловлены тем, что учащимся трудно согласиться с возможностью употребления данного слова, прямое значение которого ими уже хорошо усвоено, в данном переносном значении. Это про- 
исходит в тех случаях, когда нет соответствия с возможностями родного языка учащихся, но может иметь место и в тех случаях, когда употребление иностранного слова в переносном значении имеет соответствующую параллель в родном языке.

Следует также применять специальные упражнения на употребление слов в переносном значении:

— анализ русских предложений с целью выявления в них слов, употребленных в прямом и переносном значении;

- определение характера переноса значения в выявленных словах;

- анализ английских предложений с целью выявления в них слов, употребленных в прямом и переносном значении, с последующим переводом предложений на родной язык;

- определение характера переноса значений, выявленных в словах английских предложений;

- выписывание из английского текста сочетаний, иллюстрирующих употребление слов в переносном значении;

\title{
Литература:
}

1. Қаргина, Е. М. Профильный отбор лексико-грамматического материала в профессионально-ориентированном курсе иностранного языка в техническом вузе // Современная педагогика. - 2014. - № 9 (22). - c. 48-51.

2. Комарова, Е.В. Формирование речевого механизма в процессе усвоения лексики на иностранном языке // Гуманитарные научные исследования. 2015. № 2 [Электронный ресурс]. URL: http://human.snauka. $\mathrm{ru} / 2015 / 02 / 9645$

3. орндорф, Б. Ф. Методика преподавания английского языка. - М.: Просвещение, 1958. - 325 с.

4. Рогова, Г. В., Рабинович Ф. М., Сахарова Т.Е. Методика обучения иностранным языкам в средней школе.М.: Просвещение, 1991.- 287 с.

\section{Особенности обучения работе с иноязычным текстом в вузе}

\author{
Милотаева Ольга Сергеевна, кандидат филологических наук, доцент \\ Пензенский государственный университет архитектуры и строительства
}

Данная статья посвящена рассмотрению особенностей работы над иноязычным текстом в вузе. В процеесе преподавания иностранного языка необходимо учить формулировать ядерное высказывание, извлекать необходимую информацию из текста. При этом следует иметь в виду объективнье показатели, по которым можно судить, насколько хорошо или плохо понят учащимися текст.

Ключевые слова: лексика, словообразование, фразеологическая единица, сочетаемость слов, процесс обучения, иностранный язык.

$\mathrm{O}$ дной из задач обучения иностранному языку в неязыковом вузе является обучение беспереводному пониманию иноязычного текста. К одному из важнейших умений зрелого чтения относится формулирование ядерного высказывания. Однако выявление главных смысловых компонентов текста - это вид деятельности, усваиваемый с большим трудом. Студенты зачастую не справляются с заданием выразить главное содержание прочитанного. Это может быть связано с тем, что они не могут разграничить такие понятия как, тема, идея, главное содержание, основная мысль и рема текста.

Тема текста формулируется как обобщение номинативных лексико-тематических цепочек, составляющих тематическую сетку текста. Рема текста — это та новая информация, которая сообщается о предмете мысли. 
При работе по выявлению рематического содержания текста студентам предлагается сосредоточить свое внимание на тех частях предложений, в которых говорится, что происходит с объектом описания и каков он. Выделив или обобщив тематический и рематический ряды текста, учащиеся получают материал для построения ядерного высказывания. Оно состоит из темы и ремы текста. [1, c.80]

В целом, характер деятельности по извлечению смысла из текста зависит от характера текстовой информации. Если информация имплицитна, действия читающего сводятся к поиску необходимых обобщений в тексте. Если информация имплицитна, действия приобретают характер умозаключений или обобщений на материале содержащихся в тексте суждений. Само собой разумеется, что извлечение имплицитной информации представляет значительно большие трудности для студента, то есть извлечению имплицитного смысла надо обучать.

Для понимания имплицитного смысла необходимо формирование следующих умений:

1. Умение отвлечься от словарного значения данного слова или словосочетания, соотнести его с описываемой ситуацией, опереться на окружающий более широкий контекст и прийти к правильному пониманию имплицитного смысла.

2. Умение распознать внутренние логические отношения между двумя контактными высказываниями, которые являются имплицитно не связанными.

3. Умение восстановить пропущенные логические звенья в ходе авторского развития мысли.

4. Умение работать со структурой, состоящей из ряда фпкторов или аргументов и полностью лишенной глубинных смысловых вех, то есть авторских обобщений. Предполагается, что обобщение сделает сам читатель путем соответствующего умозаключения.

5. Умение строить текстовый и ли читательский силлогизм. Он служит инструментом проникновения в глубинный смысл текста. Малая посылка такого силлогизма опирается на факты, вычитываемые из текста. Большая посылка обеспечивается информативным запасом читателя. Своеобразие читательского силлогизма заключается в том, что любая из посылок, также как и вывод, могут либо присутствовать в тексте, либо отсутствовать. Если они имплицитны, то выражаются либо обобщенной формулировкой, либо рядом частных фактов или примеров, которые нуждаются в обобщении. Любая часть силлогизмов может быть подана в тексте в таком виде, что ее использование в предполагаемом умозаключении сопряжено с предварительной трансформацией, тот есть необходима дополнительная умственная операция со стороны читателя.

6. Умение пользоваться фоновыми знаниями для восполнения смысловых лакун.

7. Умение работать с сокращенными силлогизмами. Дело в том, что наличие всех трех элементов дедуктивного умозаключения в тексте - явление сравнительно редкое. В подавляющем большинстве случаев рассуждение про- текает в форме сокращенного или сложносокращенного силлогизма.

8. Умение найти и связать между собой рассредоточенные по тексту части силлогистического умозаключения. речь идет о распространенном типе импликации, которая строится на рассогласовании между общим суждением и конкретизирующими его предметами.

9. Умение устанавливать ассоциации на высоком уровне абстракции. [3]

Обучение пониманию иноязычного текста требует также выявления закономерностей этого процесса. При этом преподавателю важно знать, имеются ли какие-либо объективные показатели, по которым можно судить, насколько хорошо или плохо понят учащимися текст. К показателям можно отнести:

1. Нахождение в тексте предложений, являющихся ответами на вопросы, поставленные преподавателем. Данный показатель не является надежным, так как может случиться так, что читающий, не поняв общего содержания, поймет лишь те предложения, которые являются контрольными. Выбор ответа будет правильным, однако он не является индикатором понимания всего текста. Однако, возможно и обратное: понимая содержание в целом, читающий не понимает предложения, которое преподаватель обозначил как контрольное. В качестве способа контроля этот прием требует строгого и продуманного использования. Необходимо учитывать индикативную ценность контрольного предложения для всего текста. Следует также отметить, что не для всякого текста этот прием будет показателем понимания. Иногда встречаются тексты, содержание которых раскрывается в одной фразе. В этом случае прочтение этой фразы в ответ на контрольный вопрос и есть свидетельство понимания его смысла. Однако таких фраз может и не встретиться в тексте.

2. Ответы на любые вопросы по прочитанному материалу.

3. Ответы на вопросы к подтексту.

4. Составление учащимися логической серии вопросов ко всему тексту или частям текста.

5. Составление плана пересказа прочитанного текста.

6. Свободное воспроизведение текста на родном или иностранном языке.

7. Составление учащимися предложений с целью проиллюстрировать употребление отдельных слов, которые являются существенными для раскрытия содержания текста.

8. Объяснение значения некоторых слов, ранее читающему не известных. но которые он мог уяснить при условии понимания всего сообщения.

9. Выделение интонацией отдельных наиболее важных по содержанию предложений.

10. Темп чтения текста.

11. Внутренняя речь. [4, с.146]

Для правильной организации и проведения контроля необходимо четко представлять его объекты в процессе обучения иноязычным видам речевой деятельности. 
Чтение со словарем является сложным видом речевой деятельности и состоит из ряда навыков и частных умений, что обуславливает многообъектность контроля и трудность в установлении самих его объектов.

Многообразие компонентов умения читать с использованием словаря требует проверки уровня сформированности всех его составляющих, а именно:

1. Уровня сформированности навыка использования словаря;

2. Степени совершенства умения рационально использовать словарь в процессе чтения;

3. Уровня понимания прочитанного. [2]

Важным моментом является то, что выделенные объекты контроля не статичны в процессе чтения, а под- вижны и их роль меняется в зависимости от стадии обучения чтению со словарем.

Важным объектом контроля любого вида чтения является уровень понимания. Ведь цель процесса чтения заключается в достижении заданного уровня понимания иноязычного текста. Это конечный результат всех операций и действий по быстрому отыскиванию слов, по минимизации числа поиска слов в словаре в процессе чтения. по декодированию смысла читаемого до обращения к словарю.

В процессе становления умения чтения с рациональным использованием словаря выделенные объекты контроля выстраиваются в обратной последовательности, то есть уровень понимания, умение рационально использовать словарь и навык пользования словарем.

Литература:

1. Вейзе, А.А. Чтение, реферирование и аннотирование иностранного текста: Учеб. пособие.- М.: Высш. шк., 1985. - 127 c.

2. Каргина, Е.М. Особенности отбора и организации языкового материала для профильного курса иностранного языка // Гуманитарные научные исследования. - 2014. - № 11 (39). - c. 80-83.

3. Комарова, Е.В. Формирование речевого механизма в процессе усвоения лексики на иностранном языке // Гуманитарные научные исследования. 2015. № 2 [Электронный ресурс]. URL: http://human.snauka. $\mathrm{ru} / 2015 / 02 / 9645$

4. Корндорф, Б. Ф. Методика преподавания английского языка. - М.: Просвещение, 1958. - 325 с.

\section{За сознательность в обучении орфографии}

Миналиева Минзифа Абубикеровна, учитель русского языка и литературы высшей категории; Рачителева Надежда Анатольевна, учитель русского языка и литературы высшей категории; Кошенкова Наталья Владимировна, учитель русского языка и литературы первой категории МБОУ «СОШ № 24» (г. Астрахань)

Данная статья посвящена проблеме различения ни и не в отрицательных местоимениях. В большинстве методических пособий о значении местоимений с ни и местоимений с не тоже нет ни слова. Учителя на практике, естественно, не выходят за пределы программы, опасаясь трудностей, связанных с указанным способом. Описаны методы обучения детей различать эти местоимения и правильно их использовать.

Ключевые слова: местоимения, ударение, способ.

$\mathrm{B}$ опрос о различении ни и не в отрицательных местоимениях - один из труднейших в программе. Даже у передовых учителей изучение этого раздела не всегда дает желательные результаты, поскольку правило основывается на ударении, которое представляет для многих учащихся очень большие трудности. Учитывая эти трудности некоторые преподаватели дополняют традиционный способ различения не и ни в местоимениях, основанный на нахождении ударения, указанием на смысловые оттенки, вносимые: частицами не и ни (частица ни - усилительная, она усиливает отрицание. Частица не - сама по себе отрицательная).

Этот способ позволяет различать рассматриваемые орфограммы в подавляющем большинстве случаев. Случаи, когда местоимение с ни употребляется при отсутствии отрицания (Кто был ничем, тот станет всем) или при подразумеваемом отрицании (ничего - подразумевается «не добился»), единичны, и о них можно не говорить в школе.

Однако о таком различении не, ни в местоимениях не говорится в школьных учебниках, нет в них и соответствующих упражнений. Все строится на определении места ударения. В большинстве методических пособий о значении местоимений с ни и местоимений с не тоже нет ни слова. Учителя на практике, естественно, не выходят за пределы программы, опасаясь трудностей, связанных с указанным способом. Между тем рекомендуемый способ разграничения не и ни в отрицательных местоимениях имеет ряд преимуществ. Он заставляет учащихся глубже вдумы- 
ваться в значение, больше активизирует их мыслительную деятельность и этим облегчает усвоение орфографии.

Опора на значение при изучении отрицательных местоимений подготавливает к изучению отрицательных и усилительных частиц в шестом классе. Познакомившись с не и ни в местоимениях, учащиеся узнают в частицах не и ни своих старых знакомых. Опора на значение избавляет, наконец, от необходимости (или, по крайней мере, ослабляет эту необходимость) давать специальное правило для разграничения не и ни в оборотах не кто иной никто иной, поскольку это разграничение тоже зависит от смысла и от наличия другого отрицания, усиливаемого частицей ни.

На первый взгляд может показаться, что правило, основанное на значении, формулируется сложнее, чем правило, опирающееся на ударение. Однако можно и это правило дать в очень краткой форме: для усиления отрицания пиши в местоимениях ни, для отрицания пиши не.

Описываемый способ имеет большую ценность для развития связной речи, так как значение местоимений с ни я местоимений с не, в отличие от ударения, раскрывается только в контексте..

Указанный путь изучения открывает более широкие возможности для разнообразных упражнений, связанных с развитием речи. Однако указанный способ в некоторых отношениях сложнее традиционного способа, основанного на нахождении ударения. Помимо понимания смысловых оттенков, отличающих ни от не, он предполагает осознание синтаксических связей между словами, умение быстро найти в предложении отрицательное слово не, которое может стоять и до, и после местоимения.

Несколько труднее уяснить роль не и ни в местоимениях никакой, ничей, играющих роль определения в. отрицательных предложениях (ни с чьей стороны не было возражений, никакая работа не страшна и т.п.). Но здесь поможет сопоставление предложений с не и ни, выбрасывание отрицательного местоимения.

Изучение не и ни в местоимениях с ориентацией на значение требует несколько иных упражнений. Осознанию этого значения прямо послужит замена отрицательными местоимениями с ни противоположных по значению местоимений весь, всякий, каждый, например:

Заменить определительное местоимение противоположным по смыслу отрицательным местоимением.

Образец: У всех оказались нужные инструменты. Ни у кого не оказалось нужных инструментов.

У всех было желание поехать за город. Все беспокоило больного. Докладчик со всем согласился. Все знали о том, что занятие кружка отложили. Наш гость обо всем расспрашивал, всем интересовался.

Учащимся можно предложить составить описания на такие, например, темы, как «Сбор грибов и ягод» (или лучше «Неудачный сбор грибов и ягод»), «Прогулка по реке» и т.д., употребив при этом несколько местоимений с не или ни (полезно записать на доске ряд местоимений: ни у кого, ни в чьей, нечего, никаких и т.д.).
Известные в методической литературе упражнения на вставку или добавление отрицательных местоимений с ни будут служить не только раскрытию усилительной роли местоимений, но и развитию связной речи, в особенности овладению навыками правильного управления. Для этого нужно только подбирать примеры с глаголами, которые учащиеся в своей речи неправильно связывают с местоимениями \{ни к чему не прикасаться, ничего не касаться).

Вот образец такого упражнения: вставить для усиления отрицательное местоимение с ни:

Не посоветоваться, не беспокоиться, не интересоваться. По радио не сообщили новостей. Эти инструменты не нужны.

Задание можно усложнить, предложив учащимся, чтобы они вставили (если это не ухудшает стиля) не одно, а два усилительных местоимения: Докладчик не согласился - Докладчик ни с кем. - «в чем не согласился.

Чтобы обратить внимание учащихся на те отрицательные слова, которые усиливаются отрицательными местоимениями с ни (не только не, но и слова нет, нельзя), полезно предложить учащимся упражнение на перестройку предложений по образцу с заменой настоящего времени прошедшим и будущим:

Списать, заменяя слово нет глаголом быть в прошедшем и в будущем времени,

Никому нет писем - никому не было писем, никому не будет писем. Ни у кого в нашем классе нет плохих отметок - ни у кого в нашем классе не было плохих отметок и т.д.

Само собой разумеется, что такие упражнения будут служить и закреплению правила о раздельном написании не с глаголами. Примеры с нет и нельзя полезно включать и в другие приведенные нами упражнения (всем разрешается купаться - никому нельзя купаться).

Приведем еще ряд упражнений, которые удобно использовать для уяснения значения местоимений:

1. Перестроить предложение так, чтобы местоимение стояло в косвенном падеже:

Никто не заметил ошибки. - Ошибка никем не была замечена. Ничто не сравнится по красоте с Қавказскими горами. - Ни с чем не сравнить по красоте Қавказские горы.

2. Перестроить предложение так, чтобы вместо отрицательного местоимения с не было бы отрицательное местоимение с ни:

Мне не с кем было посоветоваться. - Я ни с кем не советовался. Не у кого было навести справку. - Ни у кого не навели справки.

3. Заменить выделенные слова другими, близкими по смыслу с отрицательным местоимением:

Это сообщение не ново. - Это сообщение не содержит ничего нового. Не нужно зря спорить. - Не к чему зря спорить.

До изучения местоимений с ни и не была проведена в обычных условиях одна и та же контрольная диктовка. 
В диктанте были подобраны случаи, которые могли вызвать какие-либо специфические затруднения при том и при другом способе изучения.

Так, включены были отрицательные предложения не только с отрицанием не, но и с более редко встречающимися отрицаниями нельзя, нет; наряду с местоимениями, которые пишутся одним словом, были представлены и местоимения, разбитые предлогами (ни перед чем), тле найти ударение особенно трудно. После контрольных диктовок в обоих классах было проведено изучение не и ни в местоимениях двумя различными способами.

В других 6-х классах не и ни различались на основе правила об усилительной роли частицы ни. Сопоставлялись, с одной стороны, предложения с отрицательным местоимением, имеющим ни, и такие же предложения без местоимения (не говорил - никому не говорил), с другой стороны - местоимения с не и ни. Пробовали выбросить отрицательное местоимение и, наоборот, вставить отрицание не.

\section{Литература:}

1. Виноградов, В.В.Русский язык. М., 1992

2. Горшкова, К. В., Шанский Н. М.. Современный русский язык. М., 1993

3. Кузьма, А. Я., Неупокоева О. В. Русский язык. М.,2002

4. Ладыженская, Т.А., Зельманова Л. М. Практическая методика. Русский язык. М., 2003.
Невозможность таких предложений, как «никому говорил», «некого не позвать», хорошо убеждала учащихся в том, что в одном случае перед ними местоимение для усиления отрицания, что это местоимение неразрывно связано с не я что в другом случае местоимение, которое само отрицает и поэтому не нуждается в другом отрицании. Вся дальнейшая работа сопровождалась выяснением значения местоимений, нахождением отрицания не, усиливаемого местоимением.

Способ, основанный на ударении, всюду дал худшие результаты.

Как показали результаты второго диктанта, по всем школам после изучения отрицательных местоимений на основе ударения ошибки на не и на ни снизились на $41 \%$, а после изучения на основе значения-на $78 \%$.

Все сказанное относится к различению не я ни в отрицательных наречиях. Основываясь на рекомендуемом способе, здесь можно развернуть еще более разнообразную работу, обнимающую как отрицательные наречия, так и отрицательные местоимения.

\title{
Формирование произносительной культуры младших школьников
}

\author{
Ноздрина Олеся Игоревна, учитель русского языка и литературы
}

МБОУ «Смородинская СОШ» (Белгородская обл.)

Ключевые слова: орфоэпические нормы, произносительные навыки, речедвигательный аппарат, фонетические ошибки.

$\Pi^{2}$ роцесс усвоения орфоэпических норм языка происходит в основном в дошкольном и младшем школьном возрасте. Поэтому трудно преувеличить роль школы в становлении и развитии навыков правильной устной речи.

В начальной школе уделяется большое внимание пополнению и обогащению словарного запаса школьников, однако, очень мало отводится времени на обучение нормам литературного произношения - орфоэпии русского языка.

В системе речевого развития учащихся важное место занимает работа над произносительной (звуковой) стороной речи. Долгое время этому направлению не уделялось должного внимания. Считалось, что дети, поступающие в первый класс, обладают достаточным уровнем сформированности произносительных навыков, которые позволяют им свободно осуществлять речевую деятель- ность. Однако исследование произносительных навыков речи младших школьников показывает, что у большей части первоклассников имеются значительные нарушения этой стороны речи: речь многих из них отличается невнятностью, речевой аппарат работает вяло, учащиеся не умеют правильно пользоваться дыханием и голосом, у многих наблюдаются физиологические нарушения дикции (нечеткое проговаривание отдельных звуков и звукосочетаний). Все это в значительной степени сказывается на речевой активности ученика.

Первым является работа над техникой речи, которая понимается как результат правильного дыхания, чёткой дикции: речь усваивается, когда приобретается способность управлять мускулами речедвигательного аппарата. Из этой закономерности обучения речи вытекает принцип внимания к материи языка, к физическому развитию органов речи. 
Закрепление звуков, выработка четкой дикции осуществляются и в процессе описания иллюстраций. При назывании ребенком предметов, игрушек, изображенных на рисунках, учитель следит за тем, чтобы ученик отчетливо произносил отрабатываемые звуки. Работа по выработке правильного, четкого произношения звуков и по совершенствованию фонематического восприятия ведется параллельно. Иллюстрации, речевой материал подобраны так, чтобы одновременно с совершенствованием произносительной стороны речи упражнять ребенка и в различении определенных пар звуков на слух (свистящих и шипящих, глухих и звонких, твердых и мягких согласных, звуков $\Omega$ и $p$ ). При рассматривании иллюстрации ребенку предлагают среди разных предметов, игрушек найти и перечислить те, в названии которых есть определенные звуки (например, найти и перечислить сначала предметы - в названии которых есть звук $c$, потом те из них, в названии которых есть звук $m$ ) [1, с.6].

После отгадывания загадок, заучивания небольших стихотворений, в которых часто встречаются определенные пары звуков, ученику предлагают назвать слова, в которых есть дифференцируемые звуки.

В процессе заучивания стихотворений, загадок, пословиц, а также при повторении отдельных слов следует обращать внимание на соблюдение ребенком норм литературного произношения.

Поэтому вторым направлением работы по развитию речевой деятельности на произносительном уровне является организация практического усвоения младшими школьниками орфоэпических норм русского литературного языка. У ребёнка-дошкольника, который слышит и воспринимает лишь устную форму речи, навыки говорения складываются неосознанно под влиянием естественного речевого окружения. Младшие школьники, соблюдая объективные для всех говорящих по-русски законы произношения в обычной устной речи, нарушают их в процессе чтения, когда буквенный облик слова оказывает прямое воздействие на произношение. Для чтения учащихся начальных классов характерны следующие фонетические ошибки: - нередуцированное произношение безударных гласных - [м’а] чи вместо [м’иэ] чи, [в’эс’э] лятся вместо [в'ис'иэ] лятся; - произношение парных звонких согласных на конце слова и перед шумными глухими вместо глухих - эта[ж] вместо эта[ш], ска[з]ка вместо ска [c] ка; - чтение сочетаний $\mathrm{cm} н$, здн со средним согласным звуком - сви [стн] ули вместо сви [сн] ули и др.

Фонетические ошибки находятся в прямой зависимости от темпа чтения школьника: чем он ниже, тем последовательнее проявляются отклонения от фонетического произношения. Ученикам, овладевшим навыком беглого чтения целыми словами, фонетические ошибки не свойственны. Присущее чтению «орфографическое» произношение не переносится на процесс говорения: в обычной устной речи младших школьников фонетические ошибки не встречаются (исключение составляют дети, выросшие в диалектном окружении). Главной осо- бенностью орфоэпических ошибок, вызванных несоответствием звукового и буквенного состава слова, является их широкое распространение не только в озвученной письменной, но и в естественной разговорной речи детей, не связанной с книжным текстом (рассказ, беседа). С приходом ребёнка в школу основным механизмом овладения произносительными нормами продолжает оставаться имитация, подражание речи окружающих, причём важнейшим фактором становится звучащая речь учителя. Поэтому учитель должен говорить, соблюдая все правила русской орфоэпии.

Формирование и развитие у детей правил устной речи является содержанием работы над правильным произношением в начальной школе, которая определяется орфоэпическим минимумом, обязательным для усвоения младшими школьниками.

Основу орфоэпического минимума составляют правила произношения сочетания «ит»в местоимении ито и его производных: сочетания чн в отдельных словах (конечно, нарочно и т.д.); сочетания щн в существительном помощник, окончания -ого, - его (зимнего) и слова сегодня; слов иноязычного происхождения типа почтальон, район; сочетаний гк, ги в словах лёгкий, мягкий; твёрдых и мягких согласных перед $e$ в заимствованных словах.

Такой минимум включает правила литературного произношения и ударения слов и грамматических форм современного русского языка:

1. Слова с трудным ударением: алфавит, библиотека, водопровод, гусеница и т.д.

2. Заимствованные слова: (произносится твёрдо) антенна, бутерброд, компьютер, свитер, тире, термос, шоссе; (произносится мягко) музей, паштет, рельс, фанера,. шинель.

3. Слова с трудным звукосочетанием: асфальт, балерина, бульон, велосипед и т.д.

Необходимо научить детей правильно ставить ударение, ведь правильная постановка ударения является необходимым признаком культурной, грамотной речи.

Довольно часто, под влиянием окружающей речевой среды (в основном речи родителей), ребёнок слышит неверное употребление слова и воспринимает это как норму. Так, в нашей местности в речи детей наблюдаются разнообразные ошибки в постановке ударения: в существительных в именительном падеже (гусеница, крапива, щзвель, творог и др.), в существительных в родительном падеже (волка, гуся, торта и т.д.), в глаголах прошедшего времени (взяла, дала, отняла, поняла), в правильном употреблении предлогов (до бабушки, со uколь и т.п.). Часто встречается неправильная постановка ударения в сравнительном прилагательном красивее [4, с.9].

К сожалению, рассмотренные орфоэпические ошибки не всегда оцениваются учителями начальных классов как серьезные нарушения произносительных норм русского литературного языка. 
Эффективен для запоминания нормативного произношения слов приём сложения рифмовок. Учащимся предлагается подобрать рифмующееся слово к слову, предложенному учителем. Наиболее созвучные пары слов записываются на доске, после этого идёт работа в группах по составлению рифмующихся строчек. Самые ритмичные, запоминающиеся, смешные стихи разучиваем хором.

Упражнения выполняются параллельно с работой над текстом до чтения, после чтения. Это способствует регулированию силы голоса, темпа чтения, тона, в зависимости от изображенных картин, расположения духа, жанровых особенностей произведения; выбирать интонацию и пантомимические средства выразительности во время произнесения слов и реплик персонажей.
Учитель должен знать о различных концепциях, понимать сущность, достоинства и недостатки тех, на которые опирается школьный курс русского языка.

В связи с вышеизложенным мы рекомендуем с первых дней обучения ребенка в школе следить за правильной постановкой ударения в словах, неправильно произносимых не только детьми, но и их родителями, проводить разъяснительную работу на родительских собраниях. Необходимо с первых дней пребывания ребенка в школе уделять внимание работе с артикуляционным аппаратом, используя для этого логопедический материал. Нельзя забывать о примере живой речи. И, конечно же, учитель должен владеть инновационными методами и видеть перспективы развития школьного обучения русскому языку.

Литература:

1. Блягоз, З.У. Жемчужины народной мудрости. Майкоп, Адыгейское книжное издательство, 1992 г.

2. Бондаренко, А.А.,. Қалинчук М.Л. Формирование навыков литературного произношения у младших школьников. - М., Просвещение, 1990 г.

3. Бородич, А. М. Методика развития речи детей, М., 2001 г.

4. Борунова, С.Н., Воронцова В.Л., Еськова Н.А. Орфоэпический словарь русского языка: Произношение, ударения, грамматические формы/ Под. ред. Р.И. Аванесова. М., 2003

5. Жедек, П.С. Вопросы теории и методики обучения фонетике, орфоэпии, графике и орфографии. Пеленг, 1992 г.

6. Қаленчук, М. Л., Қасаткина Р. Ф. Словарь трудностей русского произношения: Ок. 15000 слов. М., 1997 г. 


\title{
МолоАой ученый
}

\author{
Ежемесячный научный журна^ \\ № $5(85) / 2015$
}

\section{РЕДАКЦИОННАЯ КОЛЛЕГИЯ:}

Главный редактор:

Ахметова Г.Д.

Члены редакционной коллегии:

Ахметова М.Н.

Иванова Ю. В.

Каленский А. В.

Лактионов К. С.

Сараева Н.М.

Авдеюк О.А.

Алиева Т.И.

Ахметова В. В.

Брезгин В. С.

Данилов О.Е.

Дёмин А. В.

Дядюн К. В.

Желнова К.В.

Жуйкова Т.П.

Игнатова М.А

Коварда В.В.

Комогорцев М.Г.

Котляров А.В.

Кузьмина В. М

Кучерявенко С.А.

Лескова Е. В.

Макеева И.А.

Матроскина Т. В

Мусаева У.А.

Насимов М. О.

Прончев Г.Б.

Семахин А. M.

Сенюшкин Н. С.

Ткаченко И.Г.

Яхина А. С.
Ответственные редакторы:

Кайнова Г. А., Осянина Е.И.

Международный редакционный совет:

Айрян 3.Г. (Армения)

Арошидзе П. Л. (Грузия)

Атаев 3. В. (Россия)

Борисов В. В. (Украина)

Велковска Г.Ц. (Болгария)

Гайич Т. (Сербия)

Данатаров А. (Туркменистан)

Данилов А. М. (Россия)

Досманбетова 3.Р. (Казахстан)

Ешиев А. М. (Кыргызстан)

Игисинов Н. С. (Казахстан)

Қадыров К. Б. (Узбекистан)

Кайгородов И. Б. (Бразилия)

Каленский А. В. (Россия)

Козырева О.А. (Россия)

Лю Цзюань (Китай)

Малес Л.В. (Украина)

Нагервадзе М.А. (Грузия)

Прокопьев Н. Я. (Россия)

Прокофьева М.А. (Казахстан)

Ребезов М. Б. (Россия)

Сорока Ю.Г. (Украина)

Узаков Г.Н. (Узбекистан)

Хоналиев Н.Х. (Таджикистан)

Хоссейни А. (Иран)

Шарипов А. К. (Казахстан)

Художник: Шишков Е. А.

Верстка: Голубцов М. В.

Статьи, поступающие в редакцию, рецензируются.

За достоверность сведений, изложенных в статьях, ответственность несут авторы.

Мнение редакции может не совпадать с мнением авторов материалов.

При перепечатке ссылка на журнал обязательна.

Материалы публикуются в авторской редакции.

АДРЕС РЕДАКЦИИ:

420126, г. Казань, ул. Амирхана, 10а, а/я 231.

E-mail:info@moluch.ru

http://www.moluch.ru/

Учредитель и издатель:

ООО «Издательство Молодой ученый»

ISSN 2072-0297

Тираж 1000 экз.

Отпечатано в типографии издательства «Молодой ученый», г. Қазань, ул. Академика Арбузова, д. 4 